\title{
MAPEAMENTO DE QRL PARA Xanthomonas axonopodis pv. passiflorae EM MARACUJÁ-AMARELO (Passiflora edulis Sims f. flavicarpa Deg.)
}

\author{
Frederico de Pina Matta
}

\author{
Tese apresentada à Escola Superior de Agricultura \\ "Luiz de Queiroz", Universidade de São Paulo, para \\ obtenção do título de Doutor em Agronomia, Área de \\ Concentração: Genética e Melhoramento de Plantas.
}

P I R A C I C A B A

Estado de São Paulo - Brasil Janeiro - 2005 


\title{
MAPEAMENTO DE QRL PARA Xanthomonas axonopodis pv. passiflorae EM MARACUJÁ-AMARELO (Passiflora edulis Sims f. flavicarpa Deg.)
}

\author{
Frederico de Pina Matta
}

Engenheiro Agrônomo

Orientador: Prof ${ }^{\mathrm{a}} \operatorname{Dr}^{\mathrm{a}}$ MARIA LUCIA CARNEIRO VIEIRA

\begin{abstract}
Tese apresentada à Escola Superior de Agricultura "Luiz de Queiroz”, Universidade de São Paulo, para obtenção do título de Doutor em Agronomia, Área de Concentração: Genética e Melhoramento de Plantas.
\end{abstract}

P I R A C I C A B A

Estado de São Paulo - Brasil

Janeiro - 2005 
Dados Internacionais de Catalogação na Publicação (CIP) DIVISÃO DE BIBLIOTECA E DOCUMENTAÇÃO - ESALQ/USP

Matta, Frederico de Pina

Mapeamento de QRL prara Xanthomonas axonopodis pv. passiflorae em maracujá-amarelo (Passiflora edulis Sims f. flavicarpa Deg.) / Frederico de Pina Matta. - - Piracicaba, 2005

230 p. : il. + CD-ROM.

Tese (Doutorado) - - Escola Superior de Agricultura Luiz de Queiroz, 2005. Bibliografia.

1. Bacteriose vegetal 2. Mapeamento genético 3. Marcador molecular 4. Maracujá-amarelo 5. Melhoramento genético vegetal 6. Podridão (Doença de planta) 7. Resistência genética vegetal I. Título

CDD 634.425

\section{"Permitida a cópia total ou parcial deste documento, desde que citada a fonte - O autor"}


"Saber trabalhar em equipe é muito mais sábio do que somente em grupo. Quando há a divisão do saber, além de somar forças, há a multiplicação do conhecimento" SK. 


\section{DEDICATÓRIA}

A DEUS e para "todo mundo do céu" por estarem comigo em toda a minha vida;

Aos meus pais, irmãos e à Cinthia. Enfim, aos meus familiares;

Aos meus amigos. 


\section{AGRADECIMENTOS}

À Professora Dra. Maria Lucia Carneiro Vieira por ter me recebido em seu laboratório, pela orientação e paciência concedidas durante toda a realização deste trabalho;

À Escola Superior de Agricultura "Luiz de Queiroz" (ESALQ/USP) por ter me possibilitado a realização deste curso;

À Coordenação de Aperfeiçoamento de Pessoal de Nível Superior (CAPES), pela bolsa concedida;

Aos professores do curso de Pós-Graduação em Genética e Melhoramento de Plantas pelos conhecimentos compartilhados;

Ao amigo Antônio Augusto Franco Garcia pela indiscutível colaboração para o andamento deste trabalho;

Aos professores Luis Eduardo Aranha Camargo, Jorge Alberto Marques Rezende, Isaias Olivio Geraldi, Carlos Tadeu Santos Dias e Décio Barbin pelo auxílio e valiosas sugestões;

A todos os funcionários do Departamento de Genética pelo convívio amigável e pela colaboração na execução dos experimentos;

A todos que contribuíram para a realização deste trabalho. 


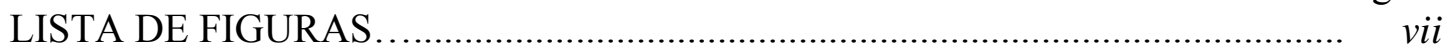

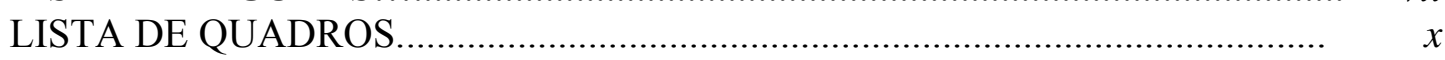

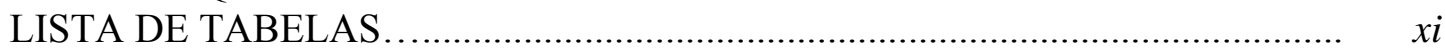

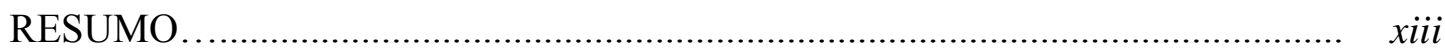

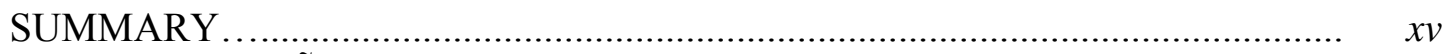

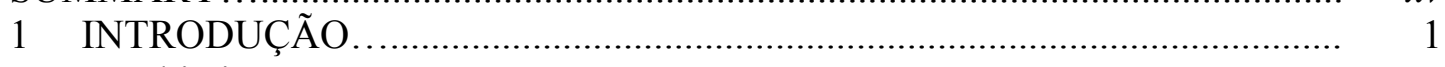

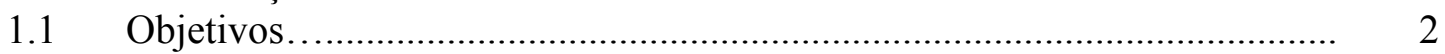

2 REVISÃO DE LITERATURA............................................................ 4

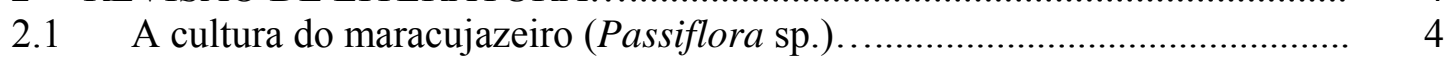

2.1.1 Produção no Brasil.............................................................................. 6

2.1.2 Comercialização interna e exportações.................................................... 10

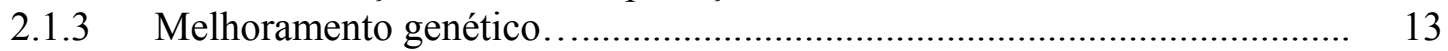

2.1.3.1 Variabilidade genética........................................................................ 13

2.1.3.2 Formas de propagação........................................................................ 17

2.1.3.3 Métodos de melhoramento.................................................................... 21

2.2 Mancha oleosa ou crestamento bacteriano.............................................. 27

2.3 Bases genéticas das doenças de plantas...................................................... 33

2.4 Marcadores moleculares..................................................................... 41

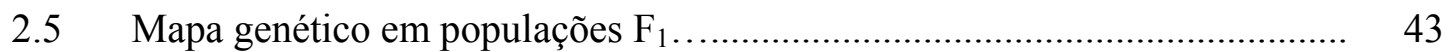

2.6 Deteç̧ão e mapeamento de QTL ............................................................... 48

2.6.1 Base genética............................................................................ 48

2.6.2 Métodos de mapeamento.............................................................. 53

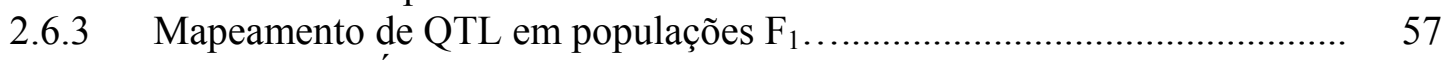

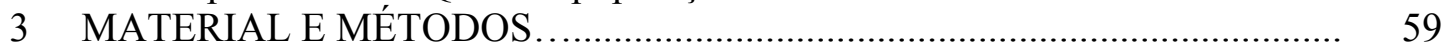

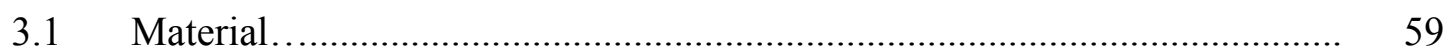

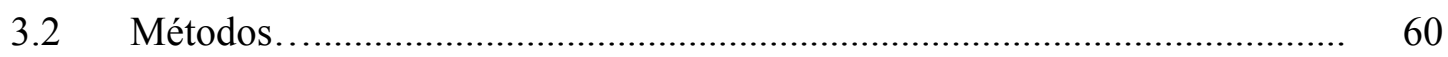

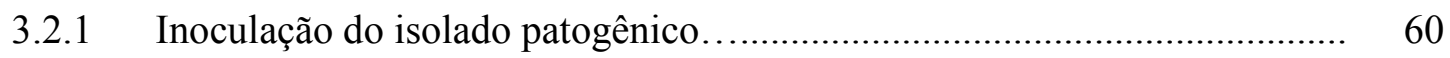

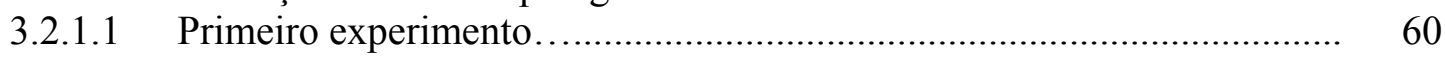

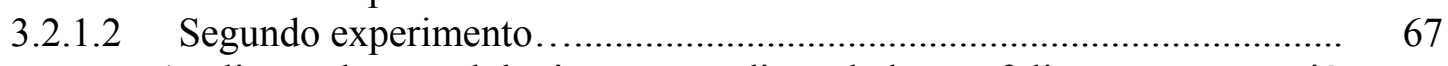

3.2.2 Avaliação de metodologias para medição de lesões foliares em maracujá-

amarelo.......................................................................................... 68

3.2.3 Análise do desenvolvimento da bacteriose em maracujá-amarelo.............. 72

3.2.4 Análises estatísticas......................................................................... 75

3.2.4.1 Análise conjunta das avaliações realizadas com o isolado " $18 \mathrm{~b}$ "............. 85

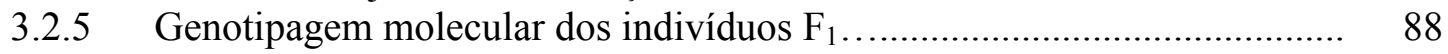


3.2.5.1 Extração do DNA genômico................................................................ 88

3.2.5.2 Quantificação do DNA genômico ........................................................ 89

3.2.5.3 Genotipagem para marcadores AFLP ............................................. 90

3.2.6 Construção dos mapas de ligação............................................................ 97

3.2.7 Mapeamento de QRL.................................................................... 98

4 RESULTADOS E DISCUSSÃO_............................................................. 101

4.1 Inoculação do isolado patogênico ................................................................. 102

4.1.1 Metodologias para medição de lesões foliares em maracujá-amarelo........... 103

4.1.2 Análise do desenvolvimento da bacteriose em maracujá-amarelo................ 111

4.1.3 Análise conjunta das avaliações realizadas com o isolado "18b" ................. 121

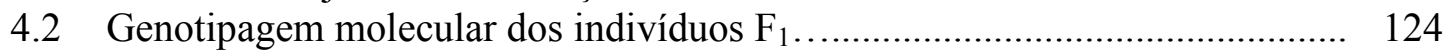

4.3 Construção dos mapas de ligação................................................................ 141

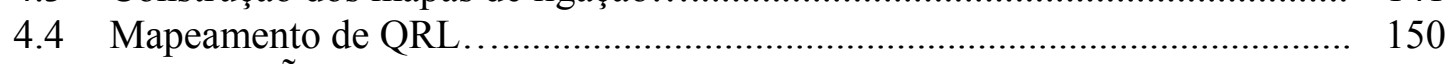

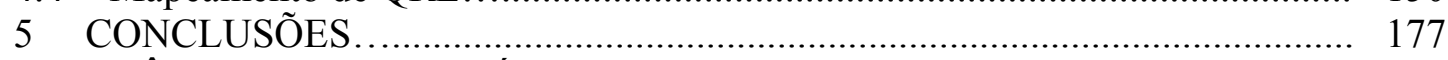

REFERÊNCIAS BIBLIOGRÁFICAS _.............................................. 178

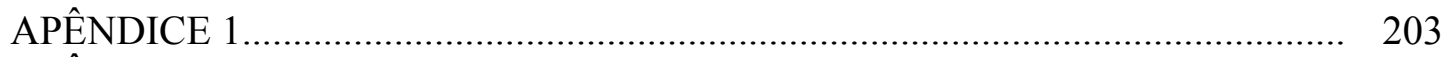

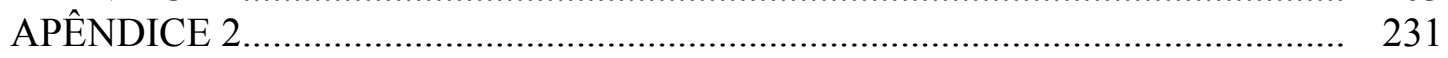




\section{LISTA DE FIGURAS}

Página

1 Exemplos de frutos comestíveis encontrados no mercado venezuelano.

2 A) Mudas tutoradas verticalmente; B) Vista geral demonstrando elevado número de plantas no interior do telado de inoculação, após 100 dias do plantio definitivo.

3 A) Identificação das folhas inoculadas; B) Forma de identificação adotada na etiqueta: primeira repetição, indivíduo 13 (8), folha 3 .

4 Vista geral do telado de inoculação, com as laterais cobertas com plástico em toda sua superfície.

5 Irrigação do piso de terra batida, realizada manualmente, para a criação de um ambiente úmido no interior do telado de inoculação.

Seqüência da metodologia adotada para inoculação, usando tesoura mergulhada em suspensão bacteriana.

Determinação das folhas para proceder a inoculação: os números indicam a posição das folhas na muda.

Teste de exsudação bacteriana (setas) realizado após o primeiro experimento, no qual foi usado o isolado " $18 \mathrm{~b}$ ".

Aspecto das folhas indicando o desenvolvimento da clorose até o pecíolo.........

10 A) Exemplo de um recorte da cópia do desenho de uma lesão desenhada em papel; B) Entrada do recorte na esteira da máquina; C) Recorte passando pela lâmpada; D) Resultado da área, em $\mathrm{cm}^{2}$, no painel da máquina.

11 Escala diagramática adotada para análise visual, proposta por Miranda (2004).

12 A) Imagem digitalizada de uma folha inoculada; B) Uso do programa computacional QUANT para obtenção da área lesionada, através da demarcação da lesão de interesse; C) Resultado, destacado em azul, mostrando que a lesão tem $22,80 \mathrm{~cm}^{2}$.

13 Disposição das plantas no telado de inoculação, em fase inicial de desenvolvimento vegetativo.

14 Primeiro experimento. Exemplo da demarcação do avanço da bacteriose aos 13, 15 e 17 dias após a inoculação do genótipo 17(35), folha 2 da terceira repetição. $\mathrm{O}$ objeto amarelo possui $2 \mathrm{~cm}$ de largura.

15 Segundo experimento. Exemplo da demarcação do avanço da bacteriose aos 13, 15 e 17 dias após a inoculação do genótipo 11(1), folha 1 da primeira repetição. 
16 Comportamento dos dados apresentados utilizando três metodologias para mensurações das lesões após inoculação da população segregante de maracujá-amarelo com Xanthomonas axonopodis pv. passiflorae

17 Discrepâncias causadas pela cópia (A - à direita), podendo ser maiores ou menores em função da posição do desenho na transparência (B).

18 Distribuição das médias fenotípicas dos dados obtidos pelas três metodologias de mensuração das lesões e valores apresentados pelos genitores (IAPAR-06 e IAPAR-123).

19 Exemplo de crescimento desuniforme das lesões conforme mostram os contornos desenhados em cada folha, nas quatro áreas (representadas por cores diferentes) tomadas a cada dois dias.....

20 Comparação entre as dispersões dos dados fenotípicos tomados a cada dois dias

21 Dispersão dos dados obtidos por Lopes (2003) e neste estudo, em diferentes datas de avaliação.

22 Parte da imagem de um gel AFLP (combinação EM24) corado com nitrato de prata contendo indivíduos da população $\mathrm{F}_{1}$, o marcador $100 \mathrm{pb}$, os genitores IAPAR-06 e IAPAR-123 (canaletas 44 e 45, a partir da esquerda) e algumas amostras de reações realizadas por Lopes (2003). Uma parte dos locos utilizados está indicada por setas.

23 Formação dos grupos de ligação usando o programa computacional JoinMap.

24 Representação esquemática das possíveis fases de ligação entre três locos hipotéticos. Loco A, do tipo bi-parental; loco B informativo, oriundo do genitor IAPAR-06; loco C informativo, oriundo do genitor IAPAR-123. Pela estratégia duplo pseudocruzamento teste, somente os locos B e C seriam mapeados se usado, por exemplo, o programa computacional Mapmaker. O JoinMap permite a construção de um único mapa para estes três marcadores.

25 Mapa genético - Grupo VII.......................................................................... 155

26 Grupo I. Mapeamento de QRL à Xanthomonas axonopodis pv.

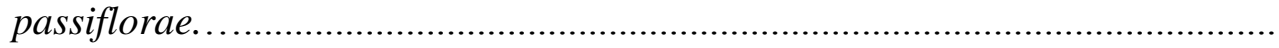

27 Grupo II. Mapeamento de QRL à Xanthomonas axonopodis pv. passiflorae.

28 Grupo III. Mapeamento de QRL à Xanthomonas axonopodis pv. passiflorae ........................................................................................

29 Grupo IV. Mapeamento de QRL à Xanthomonas axonopodis pv.

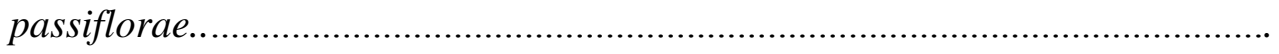

30 Grupo V. Mapeamento de QRL à Xanthomonas axonopodis pv.

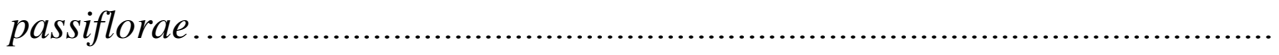

31 Grupo VI. Mapeamento de QRL à Xanthomonas axonopodis pv. passiflorae. 
32 Grupo VII. Mapeamento de QRL à Xanthomonas axonopodis pv.

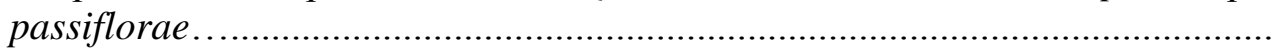

33 Grupo VIII. Mapeamento de QRL à Xanthomonas axonopodis pv. passiflorae

34 Comparação entre as metodologias para o mapeamento de QRL à Xanthomonas axonopodis pv. passiflorae para os grupos de ligação I e VI, do primeiro experimento.

35 Comparação entre as metodologias para o mapeamento de QRL à Xanthomonas axonopodis pv. passiflorae para os grupos de ligação I e III, do segundo experimento 


\section{LISTA DE QUADROS}

Página

1 Esquema das análises de variâncias para estudo das metodologias e do desenvolvimento da bacteriose, utilizando delineamento em blocos casualizados com parcelas sub-subdivididas, indicando os graus de liberdade, quadrados médios (QM) e suas respectivas esperanças $\mathrm{E}(\mathrm{QM})$.

2 Esquema das análises de variâncias utilizando delineamento em blocos casualizados com parcelas subdivididas, indicando os graus de liberdade, quadrados médios (QM) e suas respectivas esperanças $\mathrm{E}(\mathrm{QM})$.

3 Seqüência dos adaptadores e iniciadores utilizados nas reações de préamplificação.

4 Códigos atribuídos às 34 combinações de iniciadores AFLP usadas para as amplificações seletivas. Em negrito estão os 3 nucleotídeos seletivos adicionados à extremidade 3' dos iniciadores, para a realização da amplificação seletiva. 


\section{LISTA DE TABELAS}

Página

1 População segregante. Indivíduos utilizados para inoculação com isolados de Xanthomonas axonopodis pv. passiflorae e identificados com o seguinte código: os números fora dos parênteses se referem aos frutos obtidos do cruzamento e os números dentro dos parênteses se referem às mudas obtidas, a partir de sementes, do respectivo fruto ${ }^{1 /}$.

2 Temperaturas e umidades médias, máximas e mínimas apresentadas durante $o$ primeiro e segundo experimento de inoculação e desenvolvimento da 101 bacteriose $^{1 /}$.....

3 Valores médios obtidos para temperaturas máxima, média e mínima encontradas durante os dois experimentos, do período de inoculação à data da última mensuração de lesão.

4 Análise da avaliação das três metodologias adotadas para mensuração da severidade da bacteriose do maracujazeiro provocada pela inoculação com Xanthomonas axonopodis pv. passiflorae, nos dois experimentos....

5 Resumo da análise de variância para o tamanho das folhas inoculadas e indicação dos indivíduos com as maiores e menores médias ajustadas $\left(\mathrm{cm}^{2}\right)$ nos dois experimentos.

6 Observações descartadas para garantir que as premissas básicas das análises de variância fossem atendidas ${ }^{1 \dagger}$.....

7 Análise de variância dos dados de severidade da bacteriose do maracujazeiro provocada pela inoculação com Xanthomonas axonopodis pv. passiflorae, em dois experimentos.

8 Resumo das análises de variância considerando as diferentes datas de avaliação do primeiro experimento, com as respectivas áreas de lesão $\left(\mathrm{cm}^{2}\right)$ obtidas em cada oportunidade ${ }^{1 /}$....

9 Resumo das análises de variância considerando as diferentes datas de avaliação do segundo experimento, com as respectivas áreas de lesão $\left(\mathrm{cm}^{2}\right)$ obtidas em cada oportunidade ${ }^{1 /}$.....

10 Resumo das análises de variância do primeiro experimento considerando as três posições das folhas, com as respectivas áreas de lesão $\left(\mathrm{cm}^{2}\right)$ obtidas em intervalos de dois dias ${ }^{1 /}$

11 Resumo das análises de variância do segundo experimento considerando as três posições de avaliação das folhas, com as respectivas áreas de lesão $\left(\mathrm{cm}^{2}\right)$ obtidas em intervalos de dois dias ${ }^{1 /}$ 
12 Resumo das análises de variância dos dados obtidos por Lopes (2003) e os obtidos nas quatro datas de avaliação do primeiro experimento, considerando apenas os 69 indivíduos da progênie $\mathrm{F}_{1}$ comuns às duas teses. Embaixo estão os valores ajustados máximos, médios e mínimos das áreas das lesões $\left(\mathrm{cm}^{2}\right) \mathrm{e}$ o respectivo indivíduo ${ }^{1 /}$

13 Resumo das análises de variância conjunta considerando as duas épocas de avaliação: dados obtidos por Lopes (2003) e nas diferentes datas de avaliação do primeiro experimento ${ }^{1 /}$

14 Correlações entre os dados obtidos por Lopes (2003) e os dados obtidos nas quatro oportunidades de avaliação para um mesmo experimento. Acima da diagonal estão as correlações de Pearson. Abaixo da diagonal estão as correlações de Spearman...

15 Segregação dos marcadores AFLP, com o respectivo genitor informativo, número de indivíduos com os fenótipos moleculares observado na progênie, segregação esperada, valor do teste de qui-quadrado ( $\left.\chi^{2}\right)$, com 1 grau de liberdade, nível de significância e grupo de ligação ao qual a marca foi alocada.

16 Dados fenotípicos usados nas análises de QRL, considerando as médias ajustadas, com transformação logarítmica, o experimento, a data de avaliação e a posição das folhas ${ }^{1 /}$

17 Rigor utilizado para determinação de cada grupo e das fases de ligação.......... 144

18 Codificação das fases de ligação entre os marcadores informativos dos genitores IAPAR-06 e IAPAR-123, individualmente, e entre os marcadores bi-parentais, informativos em ambos genitores.

19 Número de marcadores AFLP e comprimento em cM (Haldane, 1919) de cada grupo de ligação do mapa integrado de maracujá-amarelo

20 Marcadores ligados a, pelo menos, uma das 13 variáveis fenotípicas, levandose em conta os dois experimentos ( $p$-valor $<10 \%)$.

21 Exemplo hipotético da caracterização molecular de 10 indivíduos para cinco locos marcadores

22 Simulações realizadas de forma a possibilitar a utilização de um número representativo de indivíduos e marcadores para a construção dos modelos de regressão múltipla.

23 Marcas co-fatoras obtidas a partir das simulações para a construção dos modelos de regressão múltipla....

24 Mapeamento de QRL envolvendo os dois experimentos e os dados obtidos por Lopes (2003), grupos de ligação, posição correspondente, respectivo intervalo e teste de marca simples

25 Comparações entre seleção com base no fenótipo, para cada variável, e com base nos marcadores moleculares 


\title{
MAPEAMENTO DE QRL PARA Xanthomonas axonopodis pv. passiflorae EM MARACUJÁ-AMARELO (Passiflora edulis Sims f. flavicarpa Deg.)
}

\author{
Autor: Frederico de Pina Matta \\ Orientador: $\operatorname{Prof}^{\mathrm{a}} \operatorname{Dr}^{\mathrm{a}}$ Maria Lucia Carneiro Vieira
}

\section{RESUMO}

Dando continuidade aos trabalhos realizados no Departamento de Genética da ESALQ/USP, referentes aos estudos de mapeamento de genes de resistência à bacteriose em maracujá-amarelo, foram realizados dois novos experimentos de inoculação envolvendo uma população obtida a partir do cruzamento entre 'IAPAR-06' e 'IAPAR123', ambos acessos pertencentes ao Instituto Agronômico do Paraná (IAPAR). Essa população $F_{1}$, composta de 160 indivíduos, foi utilizada para a construção dos mapas de ligação com base em marcadores AFLP, utilizando tanto marcas com segregação 1:1 quanto marcas bi-parentais 3:1, as quais serviram de ponte para a integração dos mapas construídos para cada genitor. Para a avaliação fenotípica, 104 indivíduos, além dos genitores, foram inoculados por dois isolados de Xanthomonas axonopodis pv. passiflorae, em dois experimentos distintos. Foi constatado que a resistência à bacteriose é poligênica e há, pelo menos, três locos quantitativos (QRL) envolvidos. Testes quanto à metodologia de mensuração das lesões foliares também foram realizados. Foi verificado que, independente da metodologia de avaliação fenotípica, os resultados foram equivalentes quanto ao mapeamento de QRL. De acordo com as diferentes datas de avaliação e/ou idades das folhas, QRL com diferentes efeitos foram detectados ou, até 
mesmo, QRL foram alocados em diferentes grupos de ligação. Os dados oriundos do presente estudo corroboram resultados obtidos em trabalho anterior envolvendo a mesma população de mapeamento. A utilização de um segundo isolado bacteriano possibilitou a detecção de um novo QRL. As limitações do uso de marcadores dominantes para fins de mapeamento de locos quantitativos são discutidas. 


\section{QRL mapping for Xanthomonas axonopodis pv. passiflorae in the yellow passion fruit (Passiflora edulis Sims f. flavicarpa Deg.)}

Author: Frederico de Pina Matta

Adviser: Maria Lucia Carneiro Vieira

\section{SUMMARY}

Continuing the studies carried out in the Genetics Department at ESALQ/USP concerning the mapping of resistance genes for the bacterial disease in yellow passion fruit, two new assays were conducted involving a population derived from a cross between 'IAPAR-06' and 'IAPAR-123', both accessions belonging to Instituto Agronômico do Paraná (IAPAR). This $\mathrm{F}_{1}$ population, composed of 160 individuals, was used for constructing genetic maps based on AFLP markers, using both markers with segregation 1:1 and with biparental 3:1, which act as a bridge to integrate the maps constructed for each of the parents. For phenotypic evaluation, 104 individuals plus the parents were inoculated with two isolates of Xanthomonas axonopodis pv. passiflorae in two different assays. It was seen that the resistance to bacterial disease is polygenic, and there are at least three quantitative loci (QRL) involved. Tests regarding methods for measuring leaf lesions were also carried out. It was seen that, irrespective of the methodology used for phenotypic evaluation, the results were identical for QRL mapping. Different evaluation times and/or leaf ages resulted in detection of QRL with different effects, and even QRL allocated on different linkage groups. Data derived from the present study corroborate results obtained previously involving the same mapping 
population. The use of a second bacterial isolate did allow a new QRL to be detected. The limitations of using of dominant markers for mapping quantitative loci are discussed. 


\section{INTRODUÇÃO}

O Brasil abriga o centro de diversidade genética do gênero Passiflora. A principal espécie cultivada é Passiflora edulis Sims f. flavicarpa Deg., conhecida por maracujá amarelo, uma fruteira de clima tropical com ampla distribuição geográfica. Nosso País destaca-se como o maior produtor mundial de maracujá devido às excelentes condições edafoclimáticas para o seu cultivo e à crescente evolução da área de plantio, a partir da década de 70, quando ocorreu a instalação de indústrias para o beneficiamento de suco e a aceitação comercial da fruta para consumo in natura.

Entretanto, verifica-se uma baixa produtividade que pode ser explicada por fatores nutricionais, plantas matrizes de qualidade inferior, sistemas de condução inadequados e, também, por problemas fitossanitários que aumentaram paralelamente com a ampliação da monocultura. Dentre estes problemas, as doenças podem se tornar fator limitante para o cultivo do maracujazeiro, uma vez que, quando não controladas eficientemente, causam danos irreparáveis nos pomares, acarretando prejuízos altíssimos para o produtor Com a expansão da cultura, as áreas de plantio cresceram sem obedecer aos cuidados necessários, levando a um aumento da incidência de doenças e pragas, sendo que para muitas delas não há um controle eficiente (Santos Filho et al., 1999; Dias, 2000).

Pelo exposto, verifica-se que vários esforços devem ser realizados nas áreas fitotécnica e de melhoramento genético, visando a uma efetiva melhoria da produtividade, o desenvolvimento de variedades resistentes e à melhor aceitação do produto. A área de melhoramento genético de plantas tem sido beneficiada com o desenvolvimento de métodos biotecnológicos, principalmente aqueles relativos aos 
marcadores moleculares. Uma das contribuições dessa tecnologia reside na possibilidade de se realizar uma rápida distinção de genótipos que sejam favoráveis para um programa de melhoramento, possibilitando uma redução nos custos e no tempo para a obtenção de variedades melhoradas.

Com a identificação da associação de locos que controlam caracteres quantitativos (QTL ou "Quantitative Trait Loci”) com marcadores moleculares, tornaram-se disponíveis informações mais precisas e detalhadas sobre a arquitetura genética desses caracteres. A detecção e o mapeamento desses QTL permitem identificar a magnitude dos seus efeitos, a ação gênica, o número de locos envolvidos e a respectiva distribuição no genoma. Este conjunto de informações genéticas pode orientar os procedimentos de seleção e melhoramento.

A hipótese na qual se fundamenta este trabalho é de que mapas genéticos mais densos tendem a aumentar as chances de detecção de QRL ("Quantitative Resistance Loci”) e que a sua caracterização e mapeamento são mais precisos na medida que a avaliação fenotípica da doença é mais acurada.

O presente estudo foi desenvolvido a partir de mapas moleculares construídos por Lopes $(2003)^{1}$, com base na estratégia duplo pseudocruzamento teste e em marcadores AFLP (“Amplified Fragment Lenght Polymorphism”) que revelam polimorfismos de comprimento de fragmentos gerados por restrição e amplificados, seletivamente, por reação em cadeia da polimerase (PCR). A população de mapeamento foi obtida a partir do cruzamento, idealizado por Carneiro et al. (2002), entre os acessos de maracujá-amarelo: IAPAR-06 e IAPAR-123.

\subsection{Objetivos}

Dando continuidade a essas pesquisas, o presente trabalho teve como proposta:

\footnotetext{
${ }^{1}$ Um artigo derivado desta tese, submetido para publicação, encontra-se no Apêndice 1.
} 
- Construir mapas de ligação para maracujá-amarelo usando marcadores AFLP utilizando tanto os locos que segregam 1:1 como os de segregação 3:1;

- Avaliar três metodologias para a mensuração da resistência à bacteriose do maracujazeiro causada por Xanthomonas axonopodis pv. passiflorae e verificar a existência de interação genótipo versus metodologia;

- Estudar a arquitetura genética da resistência à bacteriose;

- Detectar e mapear possíveis QRL associados ao controle da resposta da população de mapeamento à inoculação por isolados de $X$. axonopodis pv. passiflorae;

- Avaliar a existência de interação entre QRL e posição da folha inoculada;

- Avaliar a existência de interação entre QRL e data da mensuração. 


\section{REVISÃO DE LITERATURA}

\subsection{A cultura do maracujazeiro (Passiflora sp.)}

O maracujá, nome originário da língua tupi "mara cuiá", cujo significado é alimento preparado em cuia, é conhecido, também, e principalmente no exterior, como fruto da paixão ("passion fruit"). Após perceber a semelhança da morfologia das flores com a paixão de Jesus Cristo, Jacomo Bosio, em 1610, denominou as flores, em latim, de "passio floris", de onde se originou o nome da família Passifloraceae e do gênero Passiflora (Ruggiero et al., 1996; Dantas et al., 2001).

As primeiras pesquisas para desenvolver cultivos comerciais de maracujáamarelo se iniciaram em 1951, na Universidade do Havaí e, ao final desta década, o cultivo comercial passou para a América do Sul. Entretanto, o grande crescimento da cultura do maracujazeiro se deu no final dos anos 80 e início dos anos 90, quando a Venezuela, a Colômbia, o Equador, o Peru e o Brasil incrementaram sua produção para responder à demanda de suco que os europeus tinham começado a apreciar a exemplo dos sucos multivitamínicos, além do crescente interesse pelos produtos tropicais. Vale ressaltar que na corrida do crescimento e da competição, o mercado se apresentou limitado e a superprodução causou uma queda dos preços em níveis insustentáveis para os produtores, desestimulando a produção (d'Eeckenbrugge, 2003).

A queda da produção logo provocou uma recuperação dos preços. Através dos anos, a cultura passou a apresentar ciclos de crescimento e declínio, provocando variações de preços entre US\$2.000 e US\$6.000 por tonelada de suco concentrado o 
que, de certa forma, passou a assustar tanto os compradores internacionais como os produtores. Contudo, os produtores direcionaram parte de seus esforços aos mercados nacionais, os quais responderam muito favoravelmente. Na Colômbia e no Brasil, a maior parte da produção se vende no país e os consumidores da fruta fresca oferecem preços muito competitivos frente à indústria processadora (d'Eeckenbrugge, 2003).

Os dados das áreas de plantio e produção mundial de maracujá nunca foram estudados sistematicamente pela FAO (Food and Agriculture Organization of the United Nations) e pela maioria dos países produtores, havendo dados esparsos apenas, não sistematizados e sem continuidade anual. Os dados disponíveis resultam de levantamentos realizados por pesquisadores ou entidades oficias e privadas, mas sem representar uma realidade confiável em termos de produção, processamento, exportação e importação (Manica \& Oliveira Jr., 2003).

Realizar análises sobre os dados referentes à exportação de suco de maracujá, ou seja, integral congelado, com $12^{\circ}$ Brix e concentrado congelado, com $50^{\circ}$ Brix, tornou-se difícil a partir de 1996. Até 1995, se utilizava uma classificação chamada NBM (Nomenclatura Brasileira de Mercadorias), de 10 dígitos. Em 1996, o sistema de classificação mudou para NCM (Nomenclatura Comum do Mercosul, com 8 dígitos). Nesta mudança, vários códigos antigos (NBM) foram suprimidos e incorporados em um só código menos detalhado de NCM. Os sucos de maracujá e de outras frutas, como caju, coco, goiaba e pêssego passaram a se enquadrar em um só código 2009.80.00, ou seja, sucos de outras frutas ou produtos hortícolas (Sebastião Botelho Nogueira, Secretaria de Comércio Exterior, comunicação pessoal).

Mundialmente, estima-se uma produção total de 640.000 toneladas de frutos de maracujá, sendo o Brasil responsável por cerca de 70\% deste total. O Equador aparece em segundo lugar, sendo o principal abastecedor do mercado internacional de suco concentrado, com a quantidade 85.000 toneladas, a Colômbia com 30.000 e o Peru com 15.000 toneladas. Outros países produtores da América Central e da América do Sul respondem pela quantidade de 20.000 toneladas; depois vem a Ásia, com 19.000 toneladas, a Austrália e a Nova Zelândia, com a quantidade de 10.000 toneladas, a 
África, com 10.000 toneladas e, finalmente, os Estados Unidos, com a sua produção localizada no Havaí de 1.000 toneladas (Manica \& Oliveira Jr., 2003). Vale salientar que uma estimativa de produção mundial superior a 600.000 toneladas é uma cifra respeitável para um cultivo comercial iniciado há apenas 50 anos (d'Eeckenbrugge, 2003). Os principais países importadores de suco e polpa de maracujá são a Alemanha e a Holanda (Cardoso et al., 1999).

\subsubsection{Produção no Brasil}

A fruticultura brasileira é, atualmente, uma atividade agrícola de grande interesse para o País, pois agrega características importantes e desejáveis para outras atividades afins, como a demanda de um grande contingente de mão-de-obra no campo. Ao gerar empregos, esse ramo da agricultura assume importância para os estudos de sociologia rural, uma vez que se buscam alternativas viáveis para manter o homem no campo e diminuir o inchaço populacional das cidades (Manica \& Oliveira Jr., 2003).

O maracujazeiro está entre as principais espécies frutíferas cultivadas no País, com demanda, principalmente, no mercado interno, o qual absorve a maior parte da produção. A cultura caracteriza-se, ainda, por ser uma atividade predominantemente desenvolvida em pequenas propriedades, com tamanho entre 3 e 5 hectares e mão-deobra eminentemente familiar, o que representa uma alternativa para os pequenos proprietários, contribuindo para valorizar o trabalho do pequeno agricultor (Meletti, 2003; Nogueira Filho et al., 2003).

De acordo com Meletti (2003), o maracujá-amarelo (Passiflora edulis f. flavicarpa) é plantado em quase todos os estados brasileiros. Esta espécie, representa 95\% da área cultivada devido à qualidade dos seus frutos, vigor e produtividade, o que tem proporcionado renda significativa para inúmeros municípios com economia essencialmente agrícola. Os principais estados produtores são Pará, Bahia, São Paulo, Rio de Janeiro e Minas Gerais. Em menor escala, com importância bastante 
regionalizada e comercialização restrita, são cultivados o maracujá-doce (Passiflora alata), o maracujá-roxo (Passiflora edulis f. edulis), o maracujá-melão (Passiflora quadrangularis) e o maracujá-tubarão (Passiflora cincinnata), conforme apontam Inglez de Souza \& Meletti (1997). O maracujá-doce é mais representativo nos estados da região Sudeste e em Santa Catarina, e o maracujá-roxo prefere regiões de clima ameno.

Segundo Vanderplank (1991), as duas variações existentes de Passiflora edulis, uma forma de fruto roxo, Passiflora edulis f. edulis, e outra de fruto geralmente amarelo, Passiflora edulis f. flavicarpa seriam originárias do Brasil. A forma roxa ainda é encontrada em estado silvestre. Entretanto, para a forma amarela, não há relatos de sua existência em estado silvestre. As divergências ecológicas e reprodutivas entre elas deixam dúvidas sobre sua ancestralidade e até se pertençam à mesma espécie.

O maracujazeiro-amarelo é uma planta adaptada a condições de temperaturas mais elevadas. Portanto, quando cultivada em regiões com inverno mais acentuado, onde as temperaturas médias são mais baixas, ou em regiões de elevada altitude, as plantas têm nesta estação do ano seu crescimento diminuído (praticamente paralisado), com redução no número de novas brotações e, conseqüentemente, no número de flores $\mathrm{e}$ frutos. Além disso, podem ocorrer problemas de redução de produção por baixa frutificação causada pelo efeito negativo da baixa temperatura na fertilização das flores. De acordo com Vasconcellos \& Duarte Filho (2000), em regiões mais afastadas dos trópicos, ocorrem variações no comprimento do dia em função da época do ano. No inverno, o comprimento do dia cai a valores inferiores ao ideal para as plantas poderem florescer plenamente, ocorrendo uma queda acentuada ou às vezes, a paralisação total na quantidade de flores formadas.

Ao comparar o comportamento do maracujazeiro-amarelo em cultivos no Norte, Nordeste, Sudeste e Sul do Brasil, não havendo limitação por água, verifica-se que no Norte do País $\left(0^{\circ}\right.$ latitude) as plantas crescem e florescem continuamente, devido a pouca variação da temperatura e fotoperíodo ao longo do ano. Afastando-se para o Nordeste, o período de florescimento tende a diminuir (11 a 10 meses) em função da latitude, uma vez que o inverno é mais delimitado, com pequena redução na temperatura 
e no fotoperíodo. No Sudeste, o período de produção é menor que o do Nordeste, variando de 10 a 9 ou 8 meses, uma vez que as temperaturas são mais baixas e o comprimento do dia diminui mais acentuadamente no outono e inverno. Na região Sul, os efeitos da temperatura e fotoperíodo serão fortes, reduzindo ainda mais o período produtivo das plantas, quando comparados aos da região Sudeste. Vale salientar que esta sazonalidade é verificada não só na produção de frutos, mas também na qualidade e no tempo de colheita (Cançado Jr. et al., 2000; Vasconcellos \& Duarte Filho, 2000).

Considerando que a cultura ainda não atingiu o nível de melhoramento já realizado para outras culturas agrícolas, como a soja e a uva, por exemplo, verifica-se que a questão da adaptabilidade a certas condições climáticas ainda serve como obstáculo para algumas regiões brasileiras atingirem maiores patamares de produtividade. Vale salientar que, atualmente, as culturas da soja e da uva, já se encontram plenamente adaptadas a ambientes considerados como limitantes quando da sua introdução no País, como as regiões Centro-oeste e Nordeste, locais onde já possuem elevada qualidade e produtividade.

O plantio comercial teve grande expansão a partir dos anos 80. Entretanto, a falta de variedades melhoradas incentivou a multiplicação desordenada de materiais regionais sem garantia de origem, sem padrão de qualidade e altamente heterogêneas. De acordo com Stenzel \& Sera (1999), a propagação tem sido realizada através de sementes coletadas em plantios comerciais de polinização aberta, onde há grande heterogeneidade entre plantas com relação à produção, resistência a doenças entre outras características. Como resultado deste processo, há causa variação na produtividade, perda de plantas superiores de um plantio para outro, devido a cruzamentos não controlados, uma expressiva redução no potencial produtivo e qualitativo dos pomares e, conseqüentemente, a elevação do custo de produção. Este material propagativo encontra-se, muitas vezes, contaminado por patógenos dos campos de produção, erroneamente utilizados como matrizeiros, comprometendo totalmente um retorno econômico ao produtor (Scaranari \& Meletti, 2002). 
Por problemas técnicos de cultivo, degeneração da variedade local e aumento significativo da incidência de pragas e doenças, como a virose do endurecimento dos frutos, a bacteriose e a fusariose, há a ocorrência de perda da classificação, diminuição da produtividade e do aumento dos custos de produção. Por isso a cultura passou por grande redução na área de produção e no volume de fruta produzido em diversas regiões do País. Houve redução da oferta, acarretando na elevação dos preços. Esse fato fez com que a utilização de novas áreas se tornasse um atrativo para novos produtores e, até mesmo, representasse um incentivo para escapar do ataque dessas moléstias. De acordo com Meletti (2003), estes fatos favoreceram a formação dos ciclos de crescimento e declínio, dentro de nosso País, fazendo com que a cultura ficasse itinerante. Regiões outrora pujantes em produção e organização, depois de alguns anos, passaram a serem inexpressivas para produção de maracujá.

Esses exemplos relatados servem para esboçar o cenário que se encontra a cultura do maracujazeiro no Brasil, em maior ou menor grau, dependendo da região e do nível tecnológico empregado pelo produtor.

De acordo com os dados do IBGE de produção de maracujá no Brasil, no período de 1970 a 1990, observa-se que o Estado do Pará, que era o terceiro produtor em 1970, passou para o quarto lugar em 1975 e para terceiro produtor no ano de 1980, com um grande aumento do total produzido. Já no ano de 1985 passou para o quarto lugar e, novamente, com um grande aumento, passou para o primeiro lugar, em 1990, se caracterizando como o maior estado produtor.

Em 1992 a liderança do Pará foi marcante, chegando a responder por quase 50\% do total produzido. O Estado da Bahia, que era o terceiro produtor em 1970, passou a ser o primeiro em 1975, para segundo produtor em 1980, quando foi superado pelo Estado de Sergipe, mas continuou a aumentar a sua produção, passando para o segundo lugar em 1985, continuando a crescer, quando manteve a segunda posição no ano de 1990. O Estado de Sergipe não aparecia como grande produtor nos anos 70, mas aumentou muito a sua produção no ano de 1980, quando passou a ser o primeiro produtor brasileiro de maracujá. Depois, diminuiu a sua produção e passou para o segundo lugar em 1985, 
apresentando um grande aumento no ano 1990, ocupando a terceira colocação, quando foi superado pelo crescimento dos estados do Pará e da Bahia, em primeiro e segundo lugares, respectivamente. Os outros estados maiores produtores de maracujá no ano de 1990 foram Rio de Janeiro, em quarto lugar, Ceará em quinto, Minas Gerais em sexto lugar e o Estado de Alagoas em sétimo lugar (Cançado Jr. et al., 2000).

Os dados do Banco de Dados Agregados do Sistema IBGE de Recuperação Automática (SIDRA) ${ }^{2}$ demonstram que o Brasil produziu 478.652.000 frutos. Desta produção, a região Nordeste participou com 43,34\%, a região Sudeste com 40,96\%, no ano agrícola de 2002, e as regiões Norte, Centro-oeste e Sul com 7,47, 4,17 e 4,06\%, respectivamente. Considerando a produção por estados, em primeiro lugar está a Bahia, com $26,27 \%$ da produção nacional, seguida por Espírito Santo (13,17\%), São Paulo (11,90\%), Rio de Janeiro (8,67\%), Sergipe (7,90\%), Minas Gerais (7,22\%) e Pará, em sétimo, com $6,35 \%$ da produção.

Para consulta sobre a área colhida com maracujá no Brasil, os textos de Cançado Jr. et al., (2000) e Manica \& Oliveira Jr. (2003) trazem um levantamento completo das áreas destinadas a essa cultura em cada Estado, citando as principais cidades produtoras.

\subsubsection{Comercialização interna e exportações}

A produção brasileira de maracujá apresentou, na última década, um comportamento crescente até o ano de 1996. Os anos de 1997 e 1998 foram marcados por redução do total produzido, fato que pode estar relacionado com a queda na produção no estado do Pará que, até o ano de 1995, ocupou a primeira posição entre os maiores produtores. Em 1996, haviam 44.462 ha cultivados, representando um acréscimo de 75,5\% em relação à área cultivada em 1990, o que definiu um período de grande expansão para o maracujá, marcado pela valorização do preço da fruta fresca e

\footnotetext{
${ }^{2}$ Fonte: http/ www.sidra.ibge.gov.br/bda/pesquisas/pam
} 
pela modificação do hábito de consumo, até então baseado essencialmente no suco concentrado (Cançado Jr. et al., 2000; Nogueira Filho et al., 2003; Meletti, 2003).

A falta de uma oferta constante do produto para os consumidores mundiais dificulta a formação do hábito de consumo e a sua compra constante, não criando um mercado estável com garantias de lucro para os produtores. Ainda existe uma grande variação nas quantidades disponíveis no mercado, ocorrendo períodos de muita oferta, intercalados com períodos de pouca oferta, acarretando períodos de preço elevados para o consumidor ou de grandes produções de matéria-prima e conseqüentemente de preços muitos baixos pagos pela indústria (Manica \& Oliveira Jr., 2003).

Esses problemas passam a se refletir na balança comercial. Além das restrições para manter a qualidade e a quantidade da oferta no mercado externo, os exportadores brasileiros se deparam com o protecionismo dado a alguns países como os da África e do Caribe, que gozam de isenções tarifárias. Ademais, países como México, Colômbia e Equador foram recentemente contemplados com reduções tarifárias pela União Européia. No Peru, além dos altos rendimentos alcançados, a atividade se beneficia de elevados subsídios. O acesso ao mercado americano de fruto in natura de maracujá é também dificultado pela existência de barreiras fitossanitárias, havendo poucos países que atendem a essas exigências, dentre os quais, a Nova Zelândia. Além das barreiras fitossanitárias, o preço do frete reduz a competitividade do produto brasileiro naquele mercado (Cardoso et al., 1999; Cançado Jr. et al., 2000; Meletti, 2003; Nogueira Filho et al., 2003).

Considerando-se as quantidades exportadas de suco concentrado de maracujá pelo Brasil, o seu preço por tonelada, e o valor total da exportação no período de 1979 a 1995, tem sido verificada uma grande variação na quantidade anual exportada. A menor ocorreu em 1995, com apenas 248 toneladas, com valor de US\$ 538,160.00, e a maior quantidade se deu em 1988, com 8.382 toneladas. O maior valor total exportado ocorreu no ano de 1987, com valor de US\$25,351,920.00; o menor preço pago por tonelada foi de US\$ 1,200.00 no ano de 1993 e o maior preço foi de US\$ 3,820.00 no ano de 1991 (Manica \& Oliveira Jr., 2003). 
No Brasil, a comercialização do maracujá é feita em dois segmentos: consumo in natura e indústria. Ao analisar os dados sobre o volume comercializado e ofertado em três importantes centrais de abastecimento, verifica-se um crescente consumo do maracujá in natura. Este mercado absorve a maior parte da produção, estimada atualmente em cerca de $60 \%$. Os restantes $40 \%$ são consumidos pela indústria para a produção de sucos (Rossi, 2003).

Os dados oficiais disponíveis não fazem distinção entre as variedades doce e azedo, dificultando realizar comparações ou outras considerações para ambas as variedades. O maracujá-roxo, rosa-maçã e rubi têm uma pequena participação no cômputo geral da comercialização dessa fruta e, dessa forma, pode-se considerá-los marginais para efeito de análise. O maracujá-amarelo responde por mais de $90 \%$ da comercialização, sendo que no segmento de consumo de fruta fresca, segundo os dados da CEAGESP, representou 93,2\% em 2001. No período compreendido entre 1998 e 2001 se situou entre 91,7 a 95,0\%. É importante salientar que esta predominância do maracujá-amarelo tanto por parte da indústria como pelo mercado de consumo in natura, se deve, basicamente, pela ausência da oferta desses outros tipos de maracujá, e não pela preferência da fruta de cor amarela (Rossi, 2003).

Para a cultura do maracujá-doce, os dados de produção não têm sido organizados sistematicamente, sendo que, atualmente, os estados brasileiros mais conhecidos e com maior produção são: São Paulo, Santa Catarina e Distrito Federal. Desde o início dos anos 80, suas vendas têm se multiplicado por 10 no Estado de São Paulo, onde o mercado está estimado entre 200 e 400 toneladas mensais (Kavati et al., 1998). Neste caso, os dados de comercialização na CEAGESP, com frutos provenientes do Estado do Pará, indicam que a comercialização foi de 1.705 caixetas no ano de 1973, na cidade de São Paulo. Trinta anos mais tarde, foi verificada uma comercialização de 476.453 caixetas, se tendo atingido 487.227 caixetas em 2001 (Manica \& Oliveira Jr., 2003).

Quanto à preferência do consumidor, verifica-se grande interesse pela aparência do fruto, sendo, portanto, considerada como o maior indicador de qualidade. As frutas de maior calibre, com diâmetro equatorial maior que $65 \mathrm{~mm}$, sem defeitos graves, 
predominantemente (ou totalmente) na cor final são as preferidas. Alguns consumidores ainda preferem a fruta enrugada, murcha, por considerá-la menos ácida e com maior rendimento de polpa por estar desidratada. De um modo geral, para o consumo in natura, não há uma valorização dos valores intrínsecos do maracujá, como rendimento, coloração da polpa, brix, $\mathrm{pH}$, porcentagem de acidez e açúcar total como desejado pela indústria (Rossi, 2003).

Historicamente, o Brasil não tem tradição como exportador do maracujá como fruta fresca. Análises de mercado identificam amplas possibilidades para a sua exportação, notadamente do maracujá-roxo, que é o preferido pelo consumidor europeu. Os padrões de comercialização do fruto in natura de maracujá no mercado externo exigem frutos: (1) que não possuam manchas ou danos; (2) com textura lisa e bem coloridos; (3) não maduros; (4) apresentando peso entre 45 e 59 g e diâmetro entre 45 e $50 \mathrm{~mm}$; (5) embalados em bandejas de fibra plástica, com divisor interno, ou em caixas de fibra plástica com papel entre as camadas, sendo o peso total da embalagem de 2 a 3 $\mathrm{kg}$, contendo de 40 a 48 frutos, em camadas simples ou duplas. Todas estas exigências podem ser adotadas pelo produtor com relativa facilidade. Entretanto, quanto ao quesito mancha dos frutos, deve se ter uma preocupação maior, pois isso pode ser conseqüência da ação de um patógeno (Cardoso et al., 1999; Rossi, 2003).

\subsubsection{Melhoramento genético}

\subsubsection{Variabilidade genética}

O gênero Passiflora é originário da América do Sul e tem no centro-norte do Brasil o maior centro de distribuição geográfica (Leitão Filho \& Aranha, 1974). De acordo com Escobar, 1988, citado por Muschner et al. (2003), a família Passifloraceae é dividida em duas tribos: Paropsieae, com 6 gêneros, e Passifloreae, com 14 gêneros, sendo que no Brasil são encontrados quatro: Passiflora, Dilkea, Mitostemma e Tetrastylis (Cervi, 1986). 
O gênero Passiflora é o maior e mais representativo da família Passifloraceae, na qual estão reunidas de 400 a 500 espécies de maracujá, sendo $90 \%$ delas originárias das Américas e muitas delas nativas do Brasil (Inglez de Souza \& Meletti, 1997). Grande parte destas espécies está dispersa no território nacional, o que confere ao nosso País também a condição de um dos principais centros de diversidade genética do gênero (d'Eeckenbrugge, 2003).

Martín \& Nakasone (1970) estimaram que existam entre 50 e 60 espécies comestíveis de Passiflora (Figura 1). A Colômbia conta com 136 espécies de Passiflora (Hernández \& Bernal, 2000), com maior diversidade de espécies nativas e, também, com maior diversidade de passifloras cultivadas comercialmente, como o maracujá-amarelo (P. edulis f. flavicarpa), o maracujá-roxo ( $P$. edulis f. edulis), a curuba de Castilla ( $P$. tripartita var. mollissima), a curuba quiteña ( $P$. tarminiana), a curuba vermelha $(P$. cumbalensis), a granadilha ( $P$. ligularis), o maracujá-melão ( $P$. quadrangularis), o maracujá-de-osso (P. maliformis) e a granadilha de Quixos (P. Popenovii). O Brasil, com mais de 120 espécies, o Equador e o Peru, com mais de 80, também têm uma diversidade importante, mas os cultivos estão essencialmente consagrados no maracujáamarelo.

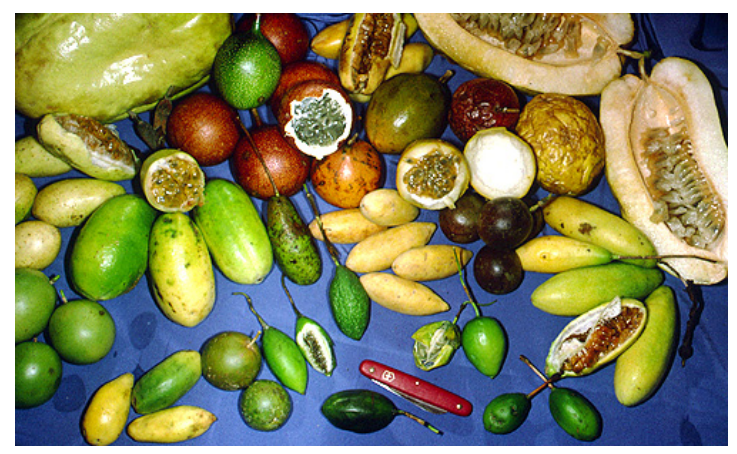

Figura 1 - Exemplos de frutos comestíveis encontrados no mercado venezuelano ${ }^{3}$

As espécies de maior importância econômica, como $P$. edulis e outras, têm $2 \mathrm{n}=18$ cromossomos, mas espécies com $2 \mathrm{n}=12,14,20,24,27,36$ e 84 também são

\footnotetext{
${ }^{3}$ Fonte: http/ www.ridgwaydb.mobot.org/mobot/photoessays/
} 
conhecidas (Snow, 1993; Passos, 1999). A viabilidade é relativamente alta em cruzamentos interespecíficos dentro do grupo com $2 n=18$. Entretanto, alguns híbridos são estéreis como P. edulis x P. giberti (Oliveira, 1996).

Dentre as poucas Passifloras já estudadas, foram observadas grandes variações no florescimento, produtividade, resistência a pragas e moléstias, tolerância ao frio e, principalmente, nas características de frutos (Akamine \& Girolami, 1959; Varajão et al., 1973; Oliveira, 1980; Oliveira et al., 1983; Urashima, 1985; Oliveira et al., 1988a; Meletti et al., 1997). Isto justifica intensificar os programas de melhoramento genético, especialmente para o maracujazeiro-amarelo, o que pode resultar em elevados ganhos com seleção.

A utilização de germoplasma nativo de maracujá-amarelo é possível e recomendável, visando explorar a variabilidade natural da espécie comercial em programas de melhoramento. Para desenvolver convenientemente um programa de melhoramento do maracujá, um pré-requisito é a caracterização do germoplasma, iniciada recentemente no Brasil (Giacometti \& Ferreira, 1977; Oliveira, 1987; Oliveira et al., 1988b; Ferreira, 1994; Meletti et al., 1994).

Algumas espécies não cultivadas têm acenado com contribuições importantes ao melhoramento genético, por apresentarem resistência a doenças ou pragas, longevidade, maior adaptação a condições climáticas adversas, período de florescimento ampliado, maior concentração de componentes químicos interessantes para a indústria farmacêutica e outras potencialidades, quase todas ainda inexploradas. Entre estas, destacam-se $P$. setacea, $P$. cincinatta, $P$. incarnata, $P$. maliformis,.P. foetida, $P$. nítida e P. quadrangularis (Meletti, 2003).

Com a expansão das fronteiras agrícolas, há uma grande preocupação quanto à extinção de espécies silvestres ainda não identificadas. É necessária a formação de bancos de germoplasma com maior diversidade de espécies possível, com vistas a ter fonte de variabilidade genética disponível (Braga \& Junqueira, 2000). 
Todo programa de melhoramento deve contar com o suporte de um bom banco de germoplasma ou coleção, composto pelo maior número possível de acessos, incluindo espécies relacionadas. A cultura tem sérios problemas devido a patógenos, como vírus e bactérias, além de ser acometida por doenças radiculares, as quais, inclusive, não têm sido controladas por ação de agroquímicos.

Esses problemas podem ser equacionados via incorporação de resistência genética, advinda de espécies relacionadas. A resistência à bacteriose foi encontrada em P. setacea, P. giberti, P. foetida, P. laurifolia e P. maliformis (Kuroda, 1981; Barbosa, 1995). Em P. suberosa, P. incarnata, P. macrocarpa foi verificada resistência ao vírus do mosaico do maracujá-roxo (Oliveira et al., 1994). Resistência a Fusarium oxysporum f. passiflorae foi encontrada em P. giberti (Oliveira, 1987), P. alata (Yamashiro \& Landgraf, 1979) e P. caerulea (Grech \& Rijkenberg, 1991). P. caerulea mostrou também resistência a Phytophthora (Grech \& Rijkenberg, 1991). Resistência ao nematóide Meloidogyne incognita foi encontrada em $P$. caerulea, $P$. edulis, $P$. edulis $\mathrm{f}$. flavicarpa, P. cincinatti e P. macrocarpa (Klein et al., 1984; Silva Jr. et al., 1988). De acordo com Knigth Jr. (1991), P. incarnata é boa fonte de resistência ao frio, que pode ser utilizada para incrementar o cultivo em zonas de clima temperado. Cabe comentar, entretanto, que essas fontes de resistência se limitam aos acessos avaliados, nem sempre disponíveis para uso ou novos estudos. Não há como generalizar para as espécies os atributos de resistência relatados por esses autores.

A preservação de germoplasma de Passiflora, no Brasil, é feita, principalmente, por meio de plantas vivas, em bancos específicos e em coleções de trabalho localizados em diversas instituições de pesquisa (Ferreira \& Oliveira, 1991). Parte dessas coleções vem sendo mantida na forma de sementes em câmaras frias e secas. Os campos são reinstalados periodicamente, quando há necessidade de rejuvenescimento dos estoques, conforme a espécie em questão (Bruckner et al., 2002). A caracterização do germoplasma vem sendo realizada por diversos pesquisadores no Brasil (Giacometti \& Ferreira, 1977; Oliveira et al., 1980; Oliveira, 1987; Oliveira et al., 1988b; Ferreira \& 
Oliveira, 1991; Meletti et al., 1992; Ferreira, 1994; Meletti et al., 1994; Cunha, 1999a; Meletti et al., 1999).

Há disponível, na natureza, uma ampla variabilidade a ser utilizada em programas de melhoramento. Entretanto, a variabilidade genética disponível nos bancos de germoplasma é bastante modesta, tanto em nível internacional, quanto nacional. Portanto, torna-se imprescindível armazenar esta variabilidade e colocá-la à disposição dos melhoristas (Ferreira, 2002).

\subsubsection{Formas de propagação}

O método predominante de propagação dos maracujás é por sementes. Devido à característica de cruzamento por polinização cruzada, há uma grande variabilidade entre as plantas de uma população. Esta característica, relacionada ao método de propagação, ocasiona a formação de pomares heterogêneos, com plantas excelentes, entremeadas por aquelas de baixa produtividade.

O maracujazeiro é uma planta alógama por excelência. A polinização cruzada é condicionada pelo fenômeno da auto-incompatibilidade, em que o pólen de uma planta é incapaz de fertilizar as flores da mesma planta, e diferentes plantas podem ou não ser compatíveis entre si. A fertilização requer a presença de diferentes genótipos (Akamine \& Girolami, 1959; Knight Jr. \& Winters, 1962; Ruggiero, 1987; Bruckner et al., 1995) e de insetos polinizadores (Akamine \& Girolami, 1959; Camillo, 1987) ou de polinização manual (Grisi Jr., 1973).

Os agentes polinizadores mais eficientes na polinização são as mamangavas (Xylocopa spp.), por causa do tamanho, visto que insetos menores coletam o néctar sem, obrigatoriamente, polinizar o estigma (Meletti, 2003). A abelha Apis mellifera tem efeito prejudicial à polinização e a ação do vento, como agente polinizador, é nula porque o pólen dos maracujás é pesado e pegajoso (Akamine \& Girolami, 1959; Ruggiero et al., 1976; Leone, 1990). 
As técnicas de cruzamentos controlados são bem simples. O florescimento é abundante e ocorre durante muitos meses. As flores são grandes, assim como suas anteras e seus estigmas. Produzem bastante pólen que pode ser coletado com facilidade. A liberação do pólen e a receptividade do estigma ocorrem no mesmo dia. Como a planta é auto-incompatível, não há necessidade de emasculações. As flores destinadas a fornecer e receber o pólen são protegidas pela manhã, antes da antese, com um saquinho de papel, de preferência parafinado. Após a abertura da flor, retira-se o saquinho da flor doadora de pólen e coleta-se o pólen, com o auxílio de cotonete, palito ou pincel. Esse pólen é, em seguida, levado à flor receptora, de onde se retira o saquinho, para, posteriormente, realizar a polinização. Uma semana após o cruzamento, é possível verificar se houve sucesso na operação. Posteriormente, é conveniente colocar uma rede de náilon envolvendo o fruto, amarrando-a ao ramo, para que o fruto não seja perdido, quando amadurecer e cair (Bruckner \& Otoni, 1999).

O pólen permanece viável, em temperatura ambiente, por 24 horas após a coleta. Se a hibridação não puder ser feita no mesmo dia, é possível coletar o pólen e realizar a polinização no dia seguinte. Temperatura e umidade baixas não se mostraram adequadas para o armazenamento de pólen do maracujazeiro (Bruckner et al., 2000).

Mesmo sendo uma espécie auto-incompatível, progênies de autofecundação podem ser obtidas pela realização da polinização na fase de botão. São necessárias duas flores da mesma planta: protege-se a flor doadora de pólen pela manhã e, à tarde, abre-se o botão da flor a ser polinizada, em cujo estigma se deposita o pólen coletado na flor em antese (Bruckner et al., 1995).

A auto-incompatibilidade do maracujazeiro é do tipo esporofítica (Bruckner et al., 1995), que tem um gene de efeito gametofítico associado ao sistema esporofítico (Suassuna et al., 2003). A reação de incompatibilidade ocorre no estigma (Knight Jr. \& Winters, 1962; Ho \& Shii, 1986; Rêgo et al., 2000). Proteínas responsáveis pela autoincompatibilidade são encontradas no estigma e na parte superior do estilete a partir de dois dias antes da antese (botão com $40 \mathrm{~mm}$ de comprimento), aumentando gradativamente até esse dia (Rêgo, 1997). A autopolinização pode também ser 
conseguida realizando-se duas autopolinizações no dia da antese, às 13 e às 17 horas. Possivelmente, a primeira autopolinização anule o efeito daquelas proteínas, de maneira que a segunda consiga, em parte, fertilizar os óvulos. As linhagens podem ser mantidas por autofecundações no estádio de botão, ou por meio de propagação vegetativa (Fernandes et al., 1996).

Cruzamentos entre plantas incompatíveis entre si podem ser realizadas de maneira análoga às autopolinizações. Entretanto, ao contrário do que ocorre em Brassica, cujo produto comercial é a parte vegetativa da planta, no maracujazeiro os híbridos devem possuir suficiente diversidade de alelos de auto-incompatibilidade para que ocorra a máxima produção de frutos. Para isso, a semente híbrida poderá ser produzida a partir de linha auto-incompatível interplantada com linha de grande diversidade de alelos de auto-incompatibilidade. As sementes deverão ser coletadas apenas na linha auto-incompatível, que poderá ser uma linhagem endogâmica ou um clone. Os alelos presentes na linha auto-incompatível deverão ter baixo nível de dominância (Bruckner et al., 1995).

Vale salientar que híbridos simples, originários de duas linhagens homozigóticas para alelos $\mathrm{S}$, não teriam interesse comercial, por serem auto-incompativeis e, conseqüentemente, improdutivos. Híbridos duplos seriam facilmente produzidos a partir de híbridos simples auto-incompativeis, mas teriam, também, insuficiente diversidade de alelos S (Bruckner et al., 1995).

Muitas espécies do subgênero Passiflora apresentam um sistema de autoincompatibilidade e fortes incompatibilidades interespecíficas (d'Eeckenbrugge et al., 1997), enquanto as poucas espécies estudadas do subgênero Tacsonia são autocompatíveis e formam híbridos interespecíficos com relativa facilidade (Escobar, 1981; Escobar, 1985; Schoëniger, 1986). Estes aspectos são essenciais na avaliação do potencial das diferentes espécies como recurso genético para o melhorista. Também, o parâmetro de autofertilidade é fundamental pela sua relação com a intensidade de seleção e endogamia que pode suportar uma espécie, sem comprometer a produção em cultivos puros (d'Eeckenbrugge, 2003). 
Mesmo sendo a propagação predominantemente realizada por sementes, alternativas ao atual método de propagação podem amenizar o problema. No entanto, observa-se que há falta de protocolos seguros para a sua realização. Mesmo que a estaquia e a enxertia possam possibilitar a perpetuação integral dos melhores genótipos, essas técnicas podem exercer decréscimo na sanidade dos pomares se não forem tomados os cuidados necessários para se evitar a disseminação de doenças, afetando a qualidade das plantas e, conseqüentemente, a produção (Nogueira Filho et al., 2003).

Embora haja registro de alguns avanços com relação à propagação vegetativa, existe um longo caminho a ser percorrido até a sua real implantação. Na estaquia, os últimos trabalhos mostram uma contaminação por vírus em mudas assim obtidas, havendo dúvidas de quando ocorreu a infecção, se ainda em viveiro ou após o plantio a campo, evidenciando a necessidade de se ter um protocolo para garantir a qualidade e a sanidade das mudas assim obtidas (Roncatto, 2003). Esses problemas vêm fazendo com que os produtores ainda continuem a realizar cruzamentos, explorando a variabilidade genética existente, visando à produção de sementes que originem plantas com as características desejadas.

Contudo, há a necessidade de estudos envolvendo pomares comerciais formados por mudas produzidas por estaquia e/ou enxertia. Pouco se sabe sobre o comportamento no campo dos indivíduos formados por estes métodos, em termos de produtividade, qualidade de frutos e suscetibilidade a doenças (Nogueira Filho et al., 2003). Vale relatar que alguns trabalhos demonstraram um excepcional pegamento das mudas através da enxertia hipocotiledonar, que pode ser um sistema complementar à enxertia convencional (Ruggiero et al., 2003).

De uma forma geral, independentemente da forma de propagação, devem ser determinadas normas para a produção de mudas certificadas, o que, inegavelmente, garantirá sua qualidade. Esforços estão sendo realizados para suprir essa necessidade dos produtores, conscientizando-os para se evitar o uso irrestrito de sementes com baixa qualidade, especialmente no que diz respeito à grande heterogeneidade genética, transmissão e multiplicação de doenças. 
Neste contexto, o IAC (Instituto Agronômico de Campinas - SP) e a Embrapa (Empresa Brasileira de Pesquisa Agropecuária) fizeram um acordo de cooperação visando à produção, difusão e comercialização de sementes e mudas fiscalizadas/certificadas de maracujazeiro-amarelo, com base nas cultivares IAC-275, para agroindústria, e nas cultivares IAC-273 e IAC-277, para frutas frescas, as quais atualmente constituem as únicas cultivares registradas no País, autorizadas para uso segundo a legislação vigente (Meletti, 2002; Meletti, 2003). O objetivo dessa iniciativa foi reverter a situação de que a maioria dos produtores tem investido grandes somas de capital em pomares formados com sementes e/ou mudas de origem desconhecida, desprovidas de seleção genética, altamente variáveis em produtividade e qualidade de fruto.

O Instituto Agronômico de Campinas detém a tecnologia para a produção de sementes e mudas de seus cultivares, já registradas, e a Embrapa - Transferência de Tecnologia responsabiliza-se pela multiplicação do material básico e sua transferência para viveiristas licenciados. Estas instituições, por sua vez, oferecem oferecendo um produto sadio, de origem garantida, padronizado pelas normas técnicas e exigências do programa, comercializando-o com um selo de qualidade que identifica o convênio IACEmbrapa (Meletti, 2002).

\subsubsection{Métodos de melhoramento}

A produtividade nacional do maracujá-amarelo ainda é muito baixa, em torno de 10 a 15 t/ha, devido, principalmente, à baixa utilização de tecnologias de produção. Em pomares com melhor nível tecnológico tem-se conseguido elevação substancial da produtividade, atingindo-se até $40 \mathrm{t} / \mathrm{ha} / \mathrm{ano}$, em virtude da adoção de práticas culturais importantes. Essas medidas consistem em adubações parceladas e mais equilibradas, uso de polinização manual, em tratos culturais adequados e no controle de pragas e doenças. Em pomares que utilizam sementes geneticamente melhoradas, além da tecnologia de 
produção apropriada, a produtividade tem alcançado níveis de até 50 t/ha/ano (Meletti \& Maia,1999; Meletti \& Bruckner, 2001).

É fato que, por falta de acesso às sementes selecionadas, a maioria dos produtores ainda retira sementes a partir de matrizes dos seus próprios pomares, resultando em pomares com excessiva heterogeneidade entre plantas com relação à produção, tamanho e formato do fruto, rendimento e qualidade do suco, resistência a doenças, entre outras características. Para os produtores, isso se traduz em variações na produtividade e perda de plantas superiores de um plantio para outro, devido a cruzamentos não controlados (Stenzel \& Sera, 1999; Meletti, 2002).

Entre os objetivos gerais do melhoramento, é fundamental atender às exigências de mercado, como aumentar a produtividade reduzindo os custos de produção e obter resistência a doenças, pois, por enquanto, o interesse está totalmente voltado ao fruto. $\mathrm{O}$ melhoramento visando atender às exigências do mercado tem a ver, principalmente, com a qualidade do fruto, mas também com a época de produção. O conceito de qualidade de frutos depende do mercado e pode ser dinâmico. Atualmente, em termos de qualidade, considera-se que uma variedade desenvolvida para o mercado in natura deve apresentar frutos grandes e ovais, cavidade interna completamente preenchida a fim de conseguir boa classificação comercial, ser resistente ao transporte e à perda de qualidade durante armazenamento e comercialização. Se desenvolvida para industrialização, precisa ter casca fina, possuir também cavidade interna completamente preenchida, conferindo alto rendimento de suco, possuir coloração amarelo-dourada estável e alto teor de sólidos solúveis, superior a 13 . Brix (Oliveira et al.,1994; Meletti \& Bruckner, 2001; Bruckner et al., 2002).

Outro objetivo relacionado ao mercado, refere-se à época de produção. De acordo com Vallini et al. (1976) e Vasconcellos \& Duarte Filho (2000), o maracujazeiro necessita de cerca de 11 horas de luz para florescer, o que faz com que nas regiões com maior latitude (Sudeste e Sul) não ocorra florescimento durante os meses de inverno. Para aumentar o período de colheita, seria necessário selecionar plantas com capacidade de florescer com fotoperíodo menor. Observa-se considerável variabilidade com relação 
a esta característica, o que leva a supor que algum progresso possa ser conseguido (Meletti, 2001).

O maracujazeiro é uma planta alógama à qual vários métodos de melhoramento são aplicáveis, objetivando o aumento da freqüência de alelos favoráveis ou a exploração do vigor híbrido ou heterose (Meletti, 1998; Meletti et al., 2000).

Em função da variabilidade genética já observada e registrada definiu-se um significativo potencial de exploração por seleção massal em Passifloras, podendo-se encontrar algumas populações selecionadas e cultivares de maracujazeiro-amarelo, apesar da distribuição consideravelmente regionalizada.

Dentre os materiais disponíveis, identificados com algum tipo de seleção dirigida, destacam-se comercialmente os três híbridos intra-varietais $F_{2}$ IAC (IAC-273, IAC-275 e IAC-277), lançados em 1999, resultantes de um programa de melhoramento de nove anos, baseado em seleção massal, retrocruzamentos e teste de progênies, além das três seleções conhecidas como 'Maguary', 'Sul-Brasil' e 'Golden Star'. Há, também, algumas poucas seleções experimentais, divulgadas no meio científico por meio de simpósios e/ou congressos nacionais (Falconer et al., 1998).

No entanto, apesar dos bons resultados experimentais, a utilização comercial desses materiais ainda é limitada pela pequena disponibilidade de sementes. Para essas seleções experimentais ainda não foram realizados testes em escala comercial, nem há sementes e mudas em quantidade suficiente para este fim, nem testes comparativos entre essas cultivares supracitadas foram feitos, ficando, portanto, circunscritas ao município ou micro-região onde foram selecionadas. Sem os testes comparativos e avaliações amplas em diversas regiões produtoras, se possível, em pelo menos três Estados da Federação, como determina a nova legislação para registro de cultivares, não há dados para avaliar corretamente seu desempenho (Meletti, 2003).

Trabalhos de melhoramento envolvendo seleção individual de plantas, hibridação, testes de progênies e seleção recorrente podem ser bastante eficientes na obtenção de cultivares de maracujazeiro mais produtivos. O sucesso no melhoramento 
genético requer que populações básicas sejam desenvolvidas e melhoradas, para serem usadas como fontes de germoplasma em programas de seleção recorrente visando à obtenção de cultivares ou à obtenção de linhagens para a produção de híbridos (Oliveira \& Ferreira, 1991; Meletti, 1998; Meletti et al., 2000).

A seleção massal é eficiente para melhorar a produção, o formato do fruto, os teores de suco e de sólidos solúveis e o vigor vegetativo (Oliveira, 1980). A seleção com teste de progênies pode ser realizada com progênies de meios-irmãos ou de irmãos completos. Progênies de meios-irmãos podem facilmente ser obtidas, coletando-se um fruto por planta selecionada. Como possui em media 250 sementes (Cunha, 1999b), um fruto é suficiente para gerar uma progênie de meios-irmãos, com várias repetições. A obtenção de progênies de irmãos completos necessita de polinização controlada entre plantas selecionadas (Bruckner et al., 1995).

De acordo com Bruckner \& Otoni (1999), variedades sintéticas e compostos também são boas opções de aproveitamento da heterose. A semente, nesses casos, pode ser multiplicada pelo produtor. Variedades sintéticas são produzidas a partir de cruzamentos, em todas as combinações, entre várias linhas endogâmicas, todas com boa capacidade de combinação. Quando as linhas são variedades ou populações de polinização livre, as populações resultantes têm sido denominadas "compostos" (Hallauer \& Miranda Filho, 1988).

Cunha (1996) propôs que a seleção massal, em maracujazeiro, seja feita na primeira colheita, com base no vigor vegetativo e na produção pendente, e as sementes coletadas, na segunda e terceira colheitas, de plantas selecionadas, polinizadas manualmente com mistura de pólen igualmente selecionado. Essa medida visa otimizar o ganho genético por ciclo, em virtude de a seleção ser feita nos dois sexos. Embora o ganho genético por ciclo seja otimizado, deve-se considerar o aumento do tempo necessário para que o ciclo seja completado, o que pode levar à redução do ganho por ano. Para conseguir o ganho máximo por ciclo e manter reduzido o tempo gasto com cada ciclo, pode-se aproveitar o fato de que o maracujazeiro floresce e produz por vários meses consecutivos. Nesse caso, é feita a avaliação no início da produção, nos meses 
iniciais, coletando-se semente das plantas selecionadas de frutos provenientes de floração após a seleção, mas ainda no mesmo ano.

A obtenção de híbridos de maracujazeiro se constitui em uma estratégia viável de melhoramento. Albuquerque (2001) observou efeitos de heterose nas dimensões do fruto, na produção e em outras características, indicando ser interessante a produção de sementes híbridas comercialmente.

Nas hibridações interespecíficas, tem-se dado ênfase à transferência de caracteres favoráveis de outras espécies para Passiflora edulis. Entretanto, a hibridação interespecífica para transferência dos genes de resistência ao maracujá comercial tem apresentado pouca aplicação prática. Híbridos interespecíficos foram obtidos combinando-se P. edulis com P. incarnata, P. coccinea ou P. setacea (Oliveira \& Ruggiero, 1998) e P. edulis f. flavicarpa com P. alata (Nakasone \& Paull, 1998). Contudo, a maioria dos híbridos interespecíficos apresenta problemas de desenvolvimento, dificuldade de florescimento, esterilidade masculina ou baixa viabilidade devido a gametas desbalanceados em relação ao número de cromossomos e alta variação morfológica nos frutos, os quais, normalmente, são intermediários entre as duas espécies e sem características comerciais desejáveis. Para recuperá-las, são necessárias muitas gerações de retrocruzamento com o genitor comercial (Priolli, 1991).

Segundo Oliveira \& Ruggiero (1998), faltam estudos detalhados de biologia floral e cruzamentos controlados para incorporar genes favoráveis das espécies silvestres em $P$. edulis f. flavicarpa e P. alata. Na tentativa de transferir a característica de tolerância ao frio de $P$. incarnata para $P$. edulis f. flavicarpa, verificou-se que todas as plantas híbridas apresentavam elevada esterilidade de pólen e ausência de frutos. Todavia, pela duplicação do número de cromossomos das progênies com colchicina e subseqüentes cruzamentos desses anfidiplóides, foi produzido um grupo de quatro híbridos $\mathrm{F}_{1}$ tetraplóides, que mostrou algum grau de compatibilidade cruzada (Knight Jr., 1991). Este estudo forneceu suporte à possibilidade de utilização da hibridação somática como estratégia de obtenção de híbridos tetraplóides, que poderiam servir como fonte de genes entre espécies silvestres e a cultivada. 
Devido à natureza complexa dos híbridos somáticos, sua utilização como fonte de genes entre espécies sexualmente incompatíveis é bastante restrita. Em Passiflora, a exemplo do que vem sendo feito em Citrus, o objetivo da hibridação por fusão celular é a geração de porta-enxertos, resistentes às doenças de solo (Vieira \& Dornelas, 1996).

Outras técnicas mais refinadas podem ser úteis, também, na preservação in vitro de germoplasma (Amugune et al., 1993; Cancino \& Hodson, 1994; Drew, 1991); para obtenção de haplóides (Tsay et al., 1984) e para a transformação genética visando à inserção de genes exógenos para conferir resistência a patógenos (Manders et al., 1994; Takahashi, 2002).

Portanto, em razão da grande variabilidade presente na espécie Passifora edulis f. flavicarpa e nas espécies relacionadas, verifica-se que o melhoramento genético poderá contribuir significativamente para a obtenção de resistência a doenças, além da elevação da produtividade e qualidade de frutos. Particularmente no melhoramento visando resistência, devem ser consideradas as doenças da parte aérea e do sistema radicular. Com relação às doenças da parte aérea, deve ser buscada a tolerância a diversos patógenos como o vírus do endurecimento dos frutos (passionfruit woodness vírus PWV), a resistência à mancha-de-alternaria (Alternaria spp.), à verrugose (Cladosporium herbarum), à antracnose (Glomerella cingulata) e à bacteriose (Xanthomonas axonopodis pv. passiflorae), entre outras. As principais doenças do sistema radicular são a fusariose, causada por Fusarium oxysporum f. sp. passiflorae, e a podridão-do-pé causada por Phytophtora spp. (Nakasone \& Paull, 1998; Liberato, 2002; Santana \& Lau, 2002).

O melhoramento dirigido à obtenção de cultivares resistentes às principais doenças envolve mais tempo e maior complexidade para a obtenção de genótipos que reúnam resistência, alta produtividade e todas as qualidades desejáveis, ou à obtenção de porta-enxertos, que podem ser de outras espécies ou híbridos interespecíficos (Oliveira et al., 1986; Grech \& Rijkenberg, 1991). Nesse caso, torna-se necessário obter portaenxertos que sejam ao mesmo tempo resistentes ou tolerantes aos fungos e nematóides, de fácil propagação (Oliveira et al., 1994) e compatíveis com a variedade da copa. 


\subsection{Mancha oleosa ou crestamentos bacteriano}

A baixa produtividade por área cultivada do maracujazeiro no Brasil pode ser explicada por fatores nutricionais, plantas matrizes de qualidade inferior, sistemas de condução inadequados e, também, por problemas fitossanitários que aumentaram paralelamente com a expansão da cultura. Dentre estes problemas, as doenças podem se tornar fator limitante para o cultivo do maracujazeiro, uma vez que a maioria, quando não controladas eficientemente, causam danos irreparáveis, acarretando em prejuízos altíssimos para o produtor (Dias, 2000; Novaes et al., 2000).

Inicialmente, os pomares são bastante sadios e vigorosos. As mudas produzidas corretamente em viveiros costumam ir para o campo em excelente estado fitossanitário, sem nenhum sintoma de doenças fúngicas ou bacterianas, apesar da facilidade de transmissão dos seus agentes causais pelo vento.

No campo, especialmente na ausência de quebra-ventos, as doenças costumam se instalar do primeiro para o segundo ano, quando a eficiência de cobertura das pulverizações deixa a desejar, em função do excesso de massa foliar (Rossi, 1998).

O maracujazeiro, instalado em local afastado de outras lavouras, e há bom tempo não explorado com plantio de maracujá, pode apresentar o seguinte comportamento: no $1^{0}$ ano agrícola ocorre baixa incidência de pragas e doenças, boa proporção de frutos de tamanho médio a grande, sadios e com bom aspecto visual; nesta situação, o produto terá preço diferenciado; no $2^{\underline{0}}$ ano agrícola ocorre aumento na produtividade, com ligeira redução no tamanho médio dos frutos, e a ocorrência de doenças e pragas. Nos anos agrícolas seguintes, as dificuldades de controle de doenças e pragas são maiores, há ainda a redução do tamanho médio dos frutos, depreciação no aspecto visual e, com isso, deságio na comercialização. Em vista desse comportamento, alguns agricultores reduzem a vida útil da cultura, às vezes re-plantando no mesmo local ou migrando para outro (Oliveira, 1998). 
Entre as doenças relatadas na literatura, a mancha oleosa, ou crestamento bacteriano, é tida como uma das principais doenças da parte aérea do maracujazeiro, provocando perdas expressivas em cultivos comerciais, sendo de ocorrência severa sob condições de clima quente e úmido (Pio-Ribeiro \& Mariano, 1997; Oliveira \& Ruggiero, 1998). O agente etiológico é Xanthomonas axonopodis pv. passiflorae, o qual, até o ano de 2000, era classificado como Xanthomonas campestris pv. passiflorae (Pereira) Dye (Gonçalves \& Rosato, 2000).

Alega-se que Xanthomonas seja um dos maiores grupos de bactérias a possuir associação com plantas. Membros desse gênero são responsáveis pela infecção de pelo menos 124 plantas monocotiledôneas e de 268 dicotiledôneas, enquanto outros membros são saprófitas e epífitas. De acordo com Hayward, 1993, citado por Chan \& Goodwin (1999), dentro desse gênero, Xanthomonas campestris é a espécie com maior destaque apresentando pelo menos 141 patovares, classificados por métodos taxonômicos clássicos.

Estima-se existir entre 20 e 100 genes envolvidos na fitopatogenicidade das Xanthomonas que é um fenômeno complexo envolvendo vários passos, começando pela penetração na planta através de ferimentos e aberturas naturais. Uma vez inserida na planta, a bactéria começa a se multiplicar nos espaços intercelulares até que esses fiquem preenchidos com bactérias e polissacarídeos bacterianos extracelulares (goma xantana). Este fato está associado com o surgimento da aparência de encharcamento e aumento da permeabilidade celular vegetal, o qual leva à perda de nutrientes. Em algumas espécies de Xanthomonas e patovares, verifica-se que as bactérias invadem o tecido vascular, onde se multiplicam e propagam-se por toda a planta. Por último, as células vegetais adjacentes às colônias bacterianas começam a se degradar, dando possibilidade para a entrada e multiplicação das bactérias. Nas plantas susceptíveis, os sintomas da doença aparecem dias depois do crescimento populacional bacteriano. Os sintomas podem incluir cloroses, necroses, murcha, hipertrofia, cancro e até morte (Chan \& Goodwin, 1999; Beatriz Appezato da Glória, 2004 - comunicação pessoal). 
Os órgãos da parte aérea do maracujazeiro podem apresentar duas formas de infecção pela bacteriose: a localizada e a sistêmica, que podem ocorrer associadas ou não. A forma localizada acontece nas folhas, principalmente nas mais internas. Os sintomas começam no limbo pelo aparecimento de pequenas lesões verde-escuras, úmido-aquosas, de aspecto oleoso e translúcido quase sempre, circundadas por um halo amarelado ou clorótico e freqüentemente localizadas próximas às nervuras. Isso leva à forma sistêmica de infecção, isto é, onde a bactéria evolui para o pecíolo, atingindo os vasos dos caules mais finos, originando intensa desfolha, seca de ponteiros e conseqüentemente, a morte prematura das plantas (Teixeira, 1994; Pio-Ribeiro \& Mariano, 1997; Santos Filho et al., 1999; Leite Jr. 2002; Liberato, 2002; Junqueira et al., 2003a; e Santos \& Santos Filho, 2003).

Nos frutos de cultivares muito susceptíveis, os sintomas são caracterizados por pequenas manchas verde-escuras, aquosas, que evoluem para áreas circulares, de aspecto oleoso e de cor pardacenta. Geralmente, as lesões não são bem visíveis em frutos verdes, mas podem ser facilmente observadas em frutos maduros. Nestes, as lesões induzidas pela bactéria são profundas (até $1 \mathrm{~mm}$ ), com bordas bem delimitadas, de formatos arredondados, coloração pardo-clara, podendo ter até $2 \mathrm{~cm}$ em diâmetro e atingir a polpa. As lesões são superficiais, podendo, no entanto, penetrar até nas sementes, inutilizando o fruto para consumo Às vezes, são confundidas com os sintomas da antracnose, cujas lesões são mais escuras, não são profundas e, geralmente, têm sinais do patógeno como acérvulos e micélios sobre o tecido lesado (Pio-Ribeiro \& Mariano, 1997; Leite Jr., 2002; Liberato, 2002; Junqueira et al., 2003a; e Santos \& Santos Filho, 2003).

A disseminação da bactéria a grandes distâncias é feita por mudas e sementes contaminadas. Dias \& Takatsu (1990) constataram cerca de $2 \%$ de transmissão via sementes. Dentro do pomar, a disseminação pode ser feita pela chuva, água de irrigação, ventos e insetos como Diabrotica speciosa (vaquinha-brasileirinho) e Lagria vilosa (besouro idiamim) que se alimentam de folhas lesadas pela bactéria. Nas folhas, a penetração da bactéria ocorre via estômatos, hidatódios e por ferimentos, tendo sua 
multiplicação entre os espaços intercelulares (Beattie \& Lindow, 1999). Nos frutos, acredita-se que a bactéria penetre diretamente pelas lenticelas e por ferimentos provocados pelo fungo Cladosporium herbarum (causador da verrugose), por pragas como tripes e pequenos coleópteros que visitam as flores durante a antese, permanecendo por alguns dias nos restos florais (Dias \& Takatsu, 1990).

Já no maracujazeiro-doce, Junqueira et al. (2003a) relatam que os sintomas nas folhas são similares àqueles observados em maracujazeiro-amarelo, mas o patógeno geralmente atinge os ramos, provocando seca e a morte das plantas, antes que estas atinjam a fase de frutificação. Nos frutos verdes, os sintomas iniciais caracterizam-se pelo aparecimento de pequenas lesões verde-escuras com aspecto aquoso e oleoso. Após dois ou três dias, as lesões aumentam de tamanho, tornam-se profundas, com a parte central mole e com bordas bem delimitadas por um halo verde escuro, podendo atingir a polpa. O tecido do centro torna-se necrótico, adquirindo coloração escura. Pode haver intensa queda de frutos em crescimento. Quando os frutos amadurecem, as lesões tornam-se totalmente escuras, profundas, podendo atingir a cavidade ovariana e as sementes.

Uma vez instalada no pomar, a bacteriose torna-se uma doença de difícil controle, sendo necessárias medidas referentes ao trato cultural, controles químico e genético. O manejo da bacteriose pela integração dessas três medidas, em condições de cerrado, tem levado a resultados satisfatórios para o maracujazeiro-amarelo, mas não para o maracujazeiro-doce. A incidência e a severidade da bacteriose diminuem consideravelmente durante o período seco, mas aumentam de forma expressiva durante o período chuvoso. A bactéria possa sobreviver em restos de cultura e, nos Cerrados, ela pode ser vista de forma endêmica em várias espécies de passifloras nativas, principalmente em $P$. amethystina, $P$. cincinnata e $P$. alata. Dessa forma, todos os plantios observados no Cerrado, por mais isolados que estejam, acabam adquirindo a doença (Junqueira et al., 2003b).

Diversas medidas têm sido recomendadas para o controle da bacteriose, entre as quais estão a produção de mudas livres da doença, poda de limpeza e aplicação de 
produtos à base de cobre. Entretanto, em alguns casos, essas medidas têm apresentado resultados contraditórios (Pio-Ribeiro \& Mariano, 1997).

Leite Jr. et al., (1999) relatam que o controle químico associado aos métodos culturais, como a poda dos ramos enfermos, foi até mesmo prejudicial, observando-se, em tais circunstâncias, que as plantas podadas definharam e morreram mais rapidamente do que as não podadas. Contrariamente, Junqueira et al. (2003b) relatam que no Distrito Federal, o controle químico da bacteriose vem oferecendo resultados satisfatórios, principalmente quando o produtor adota os tratos culturais adequados.

De acordo com Liberato (2002), Santos \& Santos Filho (2003), Junqueira et al. (2003b), dentre as principais medidas culturais, podem ser citadas:

1. Adquirir sementes e mudas certificadas e de procedência conhecida, pois a bactéria pode ser transmitida por mudas e sementes contaminadas;

2. Evitar a produção de mudas durante o período chuvoso, a não ser que seja em estufa, pois a umidade elevada favorece a infecção;

3. Evitar instalar novos plantios muito próximos de plantios mais velhos que estejam contaminados. Sempre que possível, efetuar novos plantios e destruir os pomares velhos, não mais produtivos, para evitar a manutenção do patógeno. Esta prática serve também para outras doenças do maracujazeiro;

4. Evitar utilizar sistemas de irrigação que molham a folhagem. Em termos de manejo de doenças foliares, o sistema que utiliza gotejadores é o ideal;

5. Manter as plantas, principalmente as mudas e plantas em crescimento, livres de plantas invasoras, pois estas elevam a umidade, favorecendo a ocorrência de doenças.

Considerando a resistência genética como medida de controle, em pesquisas conduzidas no Distrito Federal, com 11 cultivares de maracujazeiro-amarelo comerciais provenientes do Brasil, Porto Rico, Havaí, Ilhas Fiji e Austrália, verificou-se que a variabilidade para resistência à bacteriose entre as cultivares ou acessos é muito pequena (Junqueira et al., 2003b). Segundo Malavolta Jr. (1998), todas as variedades comerciais de maracujá existentes são suscetíveis à bacteriose. 
Wendland (1997) avaliou a resistência à Xanthomonas sp. pv. passiflorae em diferentes acessos de maracujá-amarelo e demonstrou a existência de diversos graus de resistência dentro da espécie. Esse dado demonstra que existe variabilidade dentro da espécie para essa doença. No entanto, entre plantas de uma mesma cultivar, há indivíduos que não mostram sintomas da doença, mas suas sementes têm gerado somente plantas susceptíveis. Algumas dessas plantas mais resistentes foram clonadas e multiplicadas por estaquia e continuam mantendo o nível de resistência. Resultados similares foram obtidos por Franco et al. (2002). Portanto, acredita-se que a clonagem das plantas resistentes (com boas qualidades agronômicas) selecionadas em pomares pode ter valor prático, desde que sejam multiplicadas com cuidado.

É importante ressaltar que em um programa de melhoramento para resistência a doenças, o conhecimento do germoplasma do hospedeiro e a variabilidade genética ou fisiológica do patógeno são de fundamental importância.

De acordo com o trabalho realizado por Nakatani (2001), envolvendo 50 isolados de Xanthomonas axonopodis pv. passiflorae, presentes em quatro propriedades no Estado de São Paulo, foi possível, com base em marcadores RAPD, verificar um alto grau de variabilidade genética entre os isolados, com valores de 82 a 95\%, não sendo encontrado nenhum isolado idêntico. Segundo a autora, também foi possível detectar, através de inoculações artificiais, isolados com diferentes níveis de agressividade.

Novamente, realizar estudos do germoplasma torna-se prioridade dentro de um programa de melhoramento. Leite Jr. (2002) descreve P. cincinnata, P. molissima e $P$. foetida como resistentes à bacteriose, $P$. maliformis como altamente resistente e $P$. alata e $P$. quadrangularis como altamente susceptíveis, indicando haver variabilidade no germoplasma de Passiflora spp., abrindo a possibilidade para a obtenção de materiais comerciais de maracujazeiro com resistência à doença.

Quanto ao uso de espécies selvagens, como fonte de resistência, no Distrito Federal as plantas de $P$. coccinea e de seu híbrido $\mathrm{F}_{1}$, com $P$. edulis f. flavicarpa comercial, não mostram sintomas da bacteriose em condições de campo, mas as do primeiro retrocruzamento $\left(\mathrm{RC}_{1}\right)$ para $P$. edulis f. flavicarpa já são altamente 
susceptíveis. Plantas de $P$. setacea também não mostram sintomas, mas os híbridos $\mathrm{RC}_{1}$, $\mathrm{RC}_{2}$ e $\mathrm{RC}_{3}$ para $P$. edulis f. flavicarpa são altamente susceptíveis. As plantas de $P$. caerulea, P. giberti, P. mucronata, P. actinia e de alguns acessos de $P$. nitida e $P$. laurifolia também não mostram sintomas. Por outro lado, P. amethystina, P. cincinnata, $P$. quadrangularis e $P$. alata selvagens mostraram-se altamente susceptíveis para os isolados utilizados (Junqueira et al., 2003b).

Usando procedimentos de biotecnologia como ferramentas auxiliares ao melhoramento, Vieira (2003) relata estudos que estão sendo desenvolvidos na Escola Superior de Agricultura "Luiz de Queiroz" para entender a herança do caráter, mapear genes de resistência à bacteriose do maracujazeiro e, também, produzir plantas resistentes via transgenia. O conjunto de informações que vem sendo obtido é inédito para a espécie, e deverá fornecer subsídios para trabalhos de melhoramento do maracujazeiro visando resistência à bacteriose.

Como visto, diversos relatos indicam que os esforços realizados na área fitotécnica relacionados ao controle de doenças precisam estar associados a estudos genéticos, com o intuito de se obter uma efetiva melhoria da produção e melhor aceitação do produto, principalmente in natura, no mercado interno e externo.

Após uma melhor caracterização do germoplasma, quanto às fontes de genes favoráveis nos acessos das espécies cultivadas e mesmo nas espécies silvestres, esperase que o melhoramento avance para obter bons níveis de produção, qualidade de frutos e resistência às principais doenças e assim se elimine, definitivamente, o estigma do maracujazeiro ser uma cultura nômade.

\subsection{Bases genéticas das doenças de plantas}

De uma forma geral, o controle de doenças através da resistência genética é a forma mais econômica e eficaz. Para um grande número de doenças, o grau de resistência é insuficiente para evitar perdas em níveis econômicos, exigindo, portanto, 
maior eficácia nas práticas culturais para um controle duradouro. Além disso, as fontes de resistência podem ser efêmeros, pela habilidade do patógeno em desenvolver novas raças ou biótipos, a cada vez que é desafiado com um novo gene de resistência vegetal (Yorinori \& Kiihl, 2001).

A diferença existente entre resistência controlada por um único gene e aquela controlada por vários genes se reflete no fenótipo, uma vez que a resistência como monogênica segrega qualitativamente, de maneira mendeliana, e a resistência poligênica segrega de maneira quantitativa, não discreta. Entretanto, mesmo encontrando na literatura que os termos resistência quantitativa e resistência poligênica são considerados sinônimos, vale lembrar que a recíproca pode não ser verdadeira, isto é, uma distribuição contínua de graus de resistência nem sempre implica em resistência poligênica. A variação ambiental pode mascarar o efeito dos genes sobre o fenótipo de maneira aleatória, de tal modo que uma distribuição fenotípica quantitativa pode ser obtida mesmo em casos de herança do tipo monogênica (Camargo, 1995; Camargo, 2001).

Uma característica da resistência monogênica é que o gene responsável pode interagir com genes do patógeno, conhecida como resistência vertical. Quando não há interação, diz-se que a resistência é horizontal (Vanderplank, 1963). Considerando resistência poligênica, a distinção não é tão simples com base única e exclusivamente em observações fenotípicas, uma vez que estas são resultado da segregação de vários genes de resistência que, em tese, pode ser uma mistura de resistências verticais e horizontais. Vários estudos relatam que as resistências verticais são menos duráveis, pois são passíveis de serem vencidas dentro da capacidade microevolutiva do patógeno (Camargo, 2001).

Resistência quantitativa evoca uma imagem de complexidade, com padrão de herança poligênica com múltiplos genes de pequenos efeitos aditivos nos fenótipos resistentes. Entretanto, resistência com base em vários genes de menor efeito é menos desejável, em comparação aos genes com maiores efeitos, para propósitos de melhoramento, dada a complexidade da introgressão desse tipo de resistência nos cultivares já existentes. Resistência monogênica é usualmente tida como a resistência 
que segue a teoria da interação gene-a-gene e contrasta com a resistência quantitativa pela especificidade do fenótipo, na qual para cada gene de maior efeito, condicionando a reação de resistência no hospedeiro, haverá um gene complementar no patógeno que condicionará à avirulência no patógeno (Flor, 1956; Van der Voort et al., 2000).

É comum na literatura o emprego do termo gene de maior efeito ("major gene resistance"), ou seja, resistência governada por um ou mais genes que possam produzir um padrão fenotípico descontínuo em uma população segregante. Por outro lado, há genes cujos efeitos não são grande o suficiente para que possam ser "isolados" de outras fontes de variação. Estes não podem ser estudados individualmente e são referidos como genes de efeitos menores ("minor gene resistance"), ou seja, resistência governada por genes de pequeno efeito ou secundários, produzindo um padrão fenotípico contínuo na população segregante. Quando a resistência for devida à presença de um conjunto de genes de efeito secundário, tem-se então a resistência do tipo poligênica (Vale et al., 2001). De acordo com Camargo (1995), em um dado patossistema, a ocorrência de um tipo de resistência não exclui a possibilidade de ocorrência do outro. Dados recentes obtidos a partir dos estudos com marcadores de DNA têm mostrado que de fato há genes principais, de maior efeito, em pequeno número e distribuídos em regiões específicas do genoma (haplótipo).

Todas as espécies de plantas são resistentes à maioria dos patógenos (resistência básica), ou seja, a suscetibilidade de uma planta e a virulência de um patógeno é considerada exceção. Apenas poucos patógenos conseguem desenvolver mecanismos que tornam compatíveis as interações com certas plantas, dando origem à doença. Esses mecanismos permitem a penetração e a colonização do tecido hospedeiro, de forma a suprimir ou retardar o desenvolvimento de reações de defesa por parte da planta (SilvaFilho \& Falco, 2001). Assim, na forma compatível de reação, com a planta suscetível e o patógeno virulento, a penetração do patógeno é facilmente observada na forma de lesões. Na reação de incompatibilidade, ao contrário, o patógeno pode penetrar apenas nas camadas superficiais e induzir a necrose no local (Dixon et al., 1994; Silva-Filho \& Falco, 2001). 
Existem vários mecanismos de defesa que dependem de interação entre a planta e os organismos invasores indesejáveis, como os diversos fitopatógenos (bactérias, vírus e fungos) que tentam se instalar na planta para desenvolver seu ciclo biológico. Quando a planta detecta a presença desses organismos, se estabelece uma verdadeira batalha entre o fitopatógeno e seu hospedeiro, podendo ser caracterizada genericamente como uma troca de sinais envolvendo um sistema de ataque, defesa e contra-ataque. De um lado, a planta tenta desativar o sistema de ataque do agente invasor e, do outro, o patógeno tenta desativar o sistema de defesa da planta para sobreviver. $O$ vencedor será aquele que apresentar o melhor arsenal entre as melhores estratégias de defesa (Stahl \& Bishop, 2000; Cursino-Santos et al., 2003).

Em termos evolutivos, as plantas têm desenvolvido mecanismos de defesa devidos a diferentes genes, resultando na interação gene-a-gene com os patógenos (Gabriel \& Rolfe, 1990). Pode-se dizer que, a princípio, a presença do invasor ativa no hospedeiro a produção de substâncias para evitar a instalação do microorganismo. Se mesmo assim o patógeno conseguir se instalar no tecido vegetal, é ativado um segundo mecanismo com a função de impedir a proliferação do patógeno.

Após se instalar no tecido vegetal há uma interação específica entre moléculas produzidas pelo invasor para promover a infecção e moléculas produzidas pela planta para inibir o patógeno. Esta é a fase mais crítica do processo, pois é quando se define a evolução da infecção. Se a interação dessas moléculas for eficiente e específica, a infecção será interrompida, caso contrário, a planta não conseguirá inibir o agente invasor e a infecção será efetivada. Além disso, a eficiência desse mecanismo de defesa depende do sistema de sinalização promovido a partir da interação do hospedeiro com o patógeno, acrescida de algumas características do vegetal, como idade, tecido atacado e condições fisiológicas. Quando o microrganismo invade o tecido vegetal, ocorre a liberação para o espaço intercelular ou diretamente dentro da célula dos produtos oriundos de genes R (genes de resistência) da planta (Cursino-Santos et al., 2003).

Os genes bacterianos responsáveis pelas interações compatíveis e incompatíveis entre plantas e bactérias são conhecidos como genes hrp (resposta hipersensitiva e 
patogenicidade) e genes avr (avirulência). O primeiro grupo de genes determina o resultado da interação planta-bactéria, enquanto o segundo determina a especificidade da interação (Chan \& Goodwin, 1999).

As proteínas avr são chamadas de proteínas de avirulência, visto que estas são as moléculas que definem o sucesso de infecção. Quando as proteínas avr são reconhecidas pelas proteínas $\mathrm{R}$ ocorre a desativação do arsenal de ataque do agente invasor, inibindo o processo infeccioso e, conseqüentemente, impedindo a evolução da doença. Além disso, segundo Zhu et al., 1999, citados por Cursino-Santos et al. (2003), algumas proteínas avr apresentam seqüências específicas que capacitam sua interação com fatores nucleares da célula vegetal de modo a ativar a transcrição de genes de defesa.

$\mathrm{Se}$ a proteína de avirulência do patógeno encontrar uma proteína $\mathrm{R}$ correspondente no tecido vegetal invadido, pode-se dizer que a planta é resistente a esse organismo. Na ausência do gene avr da bactéria ou dos genes de resistência, o resultado é a instalação doença. Isso porque o reconhecimento permitirá a ativação do sistema de defesa da planta e, conseqüentemente, a eliminação do patógeno. Nesse caso, não há evolução da infecção. Entretanto, se não houver uma proteína $\mathrm{R}$ correspondente à proteína avr do patógeno, a infecção progredirá e surgirão os sintomas, pois o sistema de defesa do vegetal não será acionado (Cursino-Santos et al., 2003). Em contraste, outra forma de resistência existe, a qual é denominada resistência de não hospedeiro ou resistência geral, a qual é devida a outros mecanismos que não necessariamente requerem genes vegetais de resistência (Chan \& Goodwin, 1999).

O estudo de diversidade de genes $\mathrm{R}$ bem como a organização genômica de tais genes têm despertado o interesse de diferentes pesquisadores porque tais estudos abrem novas perspectivas para $\mathrm{o}$ entendimento da evolução dos genes $\mathrm{R}$ e para $\mathrm{o}$ desenvolvimento de estratégias eficientes para o melhoramento visando resistência a doenças (Pryor \& Ellis, 1993). A evolução das interações gene-a-gene tem como conseqüência uma diversidade de genes $\mathrm{R}$ em diferentes indivíduos de uma espécie hospedeira e uma correspondente diversidade de genes de avirulência em diferentes raças do patógeno (Staskawicz et al., 1995). 
Genes de efeitos maiores (R) são sempre agrupados (“clusters" ou haplótipos) no genoma e análises moleculares têm sustentado como verdadeiro o modelo gene-a-gene para vários sistemas patógeno-hospedeiro (Hammond-Kosack \& Jones, 1997). Os genes $\mathrm{R}$ demonstram vários níveis de recombinações entre si. Genes dentro de um simples "cluster" podem determinar resistência a vários patógenos (Michelmore \& Meyers, 1998).

Acredita-se que, nesses sistemas, os genes R codificam moléculas receptoras que percebem o sinal do patógeno sobre o qual é iniciada a resposta de resistência (Baker et al., 1997). Como resultado da forte seleção para resistência monogênica, o sítio de reconhecimento no patógeno pode ser alterado em um curto espaço de tempo. Por isso, a resistência qualitativa é tida como menos durável comparativamente à quantitativa (Van der Voort et al., 2000).

Stahl \& Bishop (2000) relatam que os patógenos apresentam mecanismos adaptativos e muitas vezes conseguem vencer a batalha contra a maquinaria de defesa da planta, interagindo com proteínas da membrana da célula hospedeira e também sintetizando proteínas inibidoras que desarmam o sistema de defesa da planta. Dessa forma, se instalam e proliferam no tecido vegetal. As enzimas de ataque do patógeno e contra-ataque da planta constituem um sistema antagonista do processo de infecção. Assim, dependendo do equilíbrio entre a eficiência dos mecanismos de defesa da planta e a eficiência do fitopatógeno, a doença poderá ou não ser estabelecida. Considerando infecções causadas por bactérias do gênero Xanthomonas, existem evidências que os polissacarídeos extracelulares (EPS), também conhecidos como goma xantana, sejam determinantes de virulência. Mutações afetando a produção de EPS demonstraram limitado crescimento bacteriano e praticamente ausência de sintomas da doença (Chan \& Goodwin, 1999).

Por parte das plantas podem ocorrer alterações estruturais do tecido vegetal a fim de minimizar imediatamente a invasão do fitopatógeno, através de deposição de polissacarídeos na membrana celular. Já as alterações no ambiente celular, para torná-lo desfavorável ao desenvolvimento do patógeno, são obtidas pela produção de diversas 
substâncias (Cursino-Santos et al., 2003). As fitoalexinas, por exemplo, são substâncias que apresentam atividade antimicrobiana e características químicas bastante diversificadas (Silva-Filho \& Falco, 2001).

As fitoalexinas são compostos de baixo peso molecular, sintetizados e acumulados pelas plantas após sua exposição a microorganismos fitopatogênicos como bactérias, fungos, viroses e protozoários (Ruszkowska \& Wrobel, 2003). Alguns estudos mostraram que a defesa das plantas pelas fitoalexinas é alcançada por mecanismos que tornam certos patógenos incapazes de degradar tais compostos. De acordo com Fischer \& Hain, 1994, citados por Silva-Filho \& Falco (2001), a virulência de certos patógenos é devida a sua habilidade de inativar a fitoalexina correspondente. Isto fornece um importante ponto de partida para o uso de ferramentas moleculares visando resistência a doenças. O isolamento de genes responsáveis pelas fitoalexinas, sua modificação e transferência para outras plantas, podem levar à produção de novos compostos, resistentes aos mecanismos de detoxificação usados por certos patógenos.

A resistência a doenças pode ser aumentada pela síntese adicional de fitoalexinas em plantas transgênicas. Uma vez que diferentes plantas podem produzir diferentes fitoalexinas, a síntese adicional de um fitoalexina exógena amplia o repertório de defesas possíveis de uma planta em particular. Isso é particularmente interessante já que muitos patógenos concentram sua virulência em mecanismos capazes de detoxificar fitoalexinas (Silva-Filho \& Falco, 2001).

As plantas, em geral, apresentam ampla diversidade de proteínas $\mathrm{R}$, as quais conferem resistência a inúmeros fitopatógenos. De acordo com Salanoubat et al. (2000), citados por Cursino-Santos et al., (2003), com o sequenciamento do genoma de Arabidopsis thaliana foram identificados aproximadamente 200 genes $\mathrm{R}$ supostamente envolvidos na resistência a diversos organismos. Por outro lado, se considerarmos a ampla diversidade de fitopatógenos existentes, os genes R presentes em Arabidopsis seriam insuficientes para conferir resistência a tantas doenças. Assim, supõe-se que há muito a ser descoberto em relação à diversidade e à participação das proteínas $\mathrm{R}$ nos mecanismos de defesa da planta. 
A imagem de múltiplos genes menores responsáveis pela resistência quantitativa é inconsistente com os resultados obtidos com vários estudos de mapeamento de QTL (Quantitative Trait Loci) em diferentes sistemas hospedeiro-patógeno. Embora existam alguns exemplos de resistência quantitativa explicada por mais de cinco QTL (Geiger \& Heun, 1989; Bubeck et al., 1993; Leonards-Schippers et al., 1994; Wang et al., 1994) é mais comum encontrar-se de dois a cinco locos (Young, 1996). Nestes casos, a resistência é tida como poligênica e há poucos genes de grande efeito fenotípico.

Resistência quantitativa também pode explicar a relação clássica de gene-a-gene. A resistência em batata ao nematóide de cisto Globodera pallida pode ser atribuída a dois QRL, relacionados ao mecanismo gene-a-gene, no qual dois determinantes avirulentos distintos na população de nematóides interagem com os dois genes R (Van der Voort et al., 2000). Contudo, um gene de maior efeito que dispara uma reação de hipersensibilidade após o reconhecimento do produto do gene de avirulência pode ter seu efeito reduzido uma vez que uma versão mutante desse produto seja encontrada. Este processo foi observado para o gene de resistência de arroz Xa4 que atua como um QTL contra uma raça virulenta de Xanthomonas oryzae pv. oryzae (Li et al.,1999).

De acordo com Steffenson et al. (1996), a expressão do fenótipo de resistência também pode ser regulada conforme o estádio de desenvolvimento da planta. Os autores relatam que enquanto um único QRL foi detectado para resistência a Cochliobulos sativus em cevada no estádio de plântula, dois QRL foram encontrados em estádio adulto.

Em alguns casos, pode acontecer que um determinado QRL esteja relacionado com a resistência a diferentes doenças, podendo-se alegar um caso típico de pleiotropia. Embora essa explicação seja plausível, ela esbarra numa limitação do mapeamento genético via marcadores moleculares, onde um QRL não define um gene, e sim uma região genômica mais abrangente, na qual deve estar presente mais de um gene (Camargo, 2001). 


\subsection{Marcadores moleculares}

Os marcadores moleculares ou de DNA representam uma grande contribuição do desenvolvimento das técnicas moleculares que permitem análises do genoma. Através deles é possível analisar-se cada genótipo de interesse, possibilitando assim a obtenção de informações relativas à variabilidade existente, identificação de genótipos ou genes específicos e detectar-se possível associação entre marcadores moleculares e características fenotípicas. Os marcadores moleculares detectam o polimorfismo diretamente ao nível de DNA, não sofrendo qualquer tipo de influência ambiental ou gênica (Souza, 2001).

São consideradas características ideais para locos marcadores: (i) serem altamente polimórficos; (ii) cobrirem todo o genoma; (iii) serem seletivamente neutros, no sentido de não afetarem o caráter em questão nem as características reprodutivas do indivíduo; (iv) serem co-dominantes para que todos os possíveis genótipos possam ser identificados (Coelho \& Silva, 2002) ${ }^{4}$.

Geneticamente os marcadores moleculares podem ser divididos em dois tipos principais: a) marcadores moleculares loco-específicos codominantes, como os RFLP (Restriction Fragment Length Polymorphism) e os SSR (Simple Sequence Repeats ou microssatélites); e b) marcadores loco não específicos, como os RAPD (Random Amplified Polymorphic DNA) e os AFLP (Amplified Fragment Length Polymorphism).

Os AFLP desenvolvidos por Zabeau (1993) se baseiam na variação de comprimento de fragmentos de restrição amplificados seletivamente via PCR, reduzindo o trabalho exigido na produção dos RFLP. O AFLP se baseia no polimorfismo detectado que se traduz em padrão de fragmentos originados pela digestão do DNA genômico por duas enzimas de restrição, uma de corte raro, e uma de corte freqüente, sendo os fragmentos, neste caso, identificados por amplificação seletiva via reação de PCR (Polimerase Chain Reaction). Após a digestão, os fragmentos de restrição recebem

\footnotetext{
${ }^{4}$ COELHO, A.S.G.; SILVA, H.D. Construção de mapas genéticos e mapeamento de QTL’s. Piracicaba, 2002. 65 p. (apostila).
} 
seqüências específicas, denominadas adaptadores, que se ligam às suas extremidades. São então amplificados, seletivamente, em reações de PCR, utilizando-se como iniciadores as seqüências complementares às dos adaptadores acrescidos de 1 a 3 nucleotídeos arbitrários, que realizam a seleção dos fragmentos que serão amplificados. A separação dos fragmentos obtidos se dá em gel de poliacrilamida (gel de sequenciamento), de modo que os fragmentos de corte raro-freqüente sejam prioritariamente visualizados. Padrões diferentes de fragmentos podem ser obtidos modificando-se a combinação dos nucleotídeos adicionais aos adaptadores. Para detalhes da técnica, recomenda-se a leitura de Lopes et al. (2003).

O polimorfismo detectado pelos AFLP decorre principalmente da presença ou ausência do sítio de restrição para a enzima de corte freqüente, conferindo a estas marcas um caráter dominante, como nos RAPD. São marcadores extremamente poderosos por permitirem a realização de mapas com um número bastante reduzido de géis, pois, neste caso, cada gel é capaz de revelar a variação em até mais de uma centena de fragmentos (locos) simultaneamente (Coelho \& Silva, 2002) ${ }^{5}$. Para se obter polimorfismos em espécies com relativo baixo nível de heterozigosidade, a técnica de AFLP é mais recomendada comparativamente ao RAPD. A técnica de AFLP permite a detecção de um número maior de pontos de mutação por reação, pois é muito sensitiva para uma simples mudança de base nucleotídica que pode causar a perda ou o ganho de um sítio de restrição (Vos et al., 1995; Young et al., 1999; Yin et al., 2001).

Vários trabalhos relatam a facilidade de se gerar mapas de ligação altamente saturados a partir da técnica de AFLP (Vuylsteke et al., 1999). Além disso, segundo esses autores, ao compararem dois mapas de duas populações diferentes, a maioria dos marcadores AFLP foi comum para ambas populações, indicando que esse tipo de marcador é predominantemente de locos únicos.

\footnotetext{
${ }^{5}$ COELHO, A.S.G.; SILVA, H.D. Construção de mapas genéticos e mapeamento de QTL’s. Piracicaba, 2002. 65p. (apostila).
} 


\subsection{Mapa genético em populações $F_{1}$}

As primeiras idéias sobre mapeamento genético surgiram com os trabalhos do grupo formado por Morgan e seus colaboradores. Foi Sturtevant, em 1913, quem sugeriu a utilização da freqüência de recombinantes como uma medida da distância entre dois genes, permitindo então a construção de mapas, nos quais a posição relativa dos genes de um determinado organismo poderia ser representada. Estas idéias se desenvolveram a partir de então, ao longo das décadas de 20,30 e 40, com a participação de pesquisadores como R. A. Fisher, J. B. S. Haldane, D. D. Kosambi, A. R. G. Owen entre outros (Bailey, 1961; Provine, 1971).

As populações mais utilizadas para o mapeamento genético são provenientes de retrocruzamentos, gerações $\mathrm{F}_{2}$, conjuntos de linhagens puras recombinantes derivadas de plantas $F_{2}$ e conjuntos de linhagens duplo-haplóides obtidas de gametas de plantas $F_{1}$. Esses delineamentos genéticos possuem em comum o fato de que gerações em desequilíbrio de ligação para os locos segregantes são produzidas, permitindo a realização da análise de ligação. O desequilíbrio de ligação devido à ligação física dos locos está no seu ponto máximo nas populações derivadas de cruzamentos controlados, e como conseqüência, a capacidade de se detectar a ligação entre dois locos fisicamente ligados também está em seu ponto máximo (Coelho \& Silva, 2002) ${ }^{6}$.

Entretanto, ao se considerar espécies que possuam, por exemplo, elevado período juvenil e elevada depressão causada pela endogamia, como espécies florestais e algumas frutíferas, esses delineamentos genéticos não são muito recomendados. Portanto, foram desenvolvidas estratégias alternativas para estas situações (Ritter et al., 1990; Grattapaglia \& Sederoff, 1994; Maliepaard et al., 1997), as quais já estão sendo aplicadas a plantas cultivadas (Maliepaard et al., 1998; Carneiro et al., 2002; Lopes, 2003).

\footnotetext{
${ }^{6}$ COELHO, A.S.G.; SILVA, H.D. Construção de mapas genéticos e mapeamento de QTL's. Piracicaba, 2002. 65p. (apostila).
} 
Como este trabalho representa uma continuação dos estudos realizados por Lopes (2003), o qual utilizou marcadores moleculares com base no polimorfismo de comprimento de fragmentos amplificados (AFLP), em uma população de indivíduos $\mathrm{F}_{1}$, geneticamente segregante, algumas considerações serão realizadas para fundamentar o presente estudo.

Marcadores dominantes, como os AFLP, são altamente polimórficos e detectam apenas um alelo (presença da banda no gel) e todos os outros alelos detectados serão tidos como nulos (ausência da banda no gel). Assim, se uma planta for heterozigótica para um marcador dominante e a outra planta tiver genótipo nulo (outras formas alélicas não detectadas), a $F_{1}$ segrega 1:1 para a presença e ausência do segmento do marcador dominante detectado (Ferreira \& Grattapaglia, 1996).

Esta estratégia de mapeamento é conhecida como pseudocruzamento teste, pois a fase de ligação não pode ser conhecida à priori, como em um cruzamento teste clássico, e sim ser inferida a posteriori, após análise de segregação, onde a geração $F_{1}$, resultante de cruzamentos deste tipo, é geneticamente heterogênea. Após a genotipagem de uma amostra de várias dezenas de indivíduos $F_{1}$ para os marcadores selecionados que segreguem 1:1, dois conjuntos distintos de marcadores são gerados, sendo um para cada genitor do cruzamento, resultando em dois mapas de ligação. Assim, o termo mais apropriado é duplo pseudocruzamento teste ("two-way pseudo-testcross") (Grattapaglia \& Sederoff, 1994; Ferreira \& Grattapaglia, 1996).

Entretanto, a terminologia duplo pseudocruzamento teste apresenta-se confusa, pois segregações do tipo 3:1, para marcadores dominantes, 1:2:1 e 1:1:1:1, para marcadores co-dominantes, caso ambos genitores forem heterozigóticos, podem ser usadas em adição aos marcadores de segregação 1:1, quando somente um dos genitores for heterozigótico para determinado loco (Maliepaard et al., 1998).

Utilizando-se apenas os marcadores com segregação 1:1, dois conjuntos distintos de marcadores são detectados na progênie, cada conjunto oriundo de um genitor, resultando em dois mapas de ligação, ou seja, os mapas são indivíduo-específicos e não 
podem ser alinhados ou integrados como tais, a não ser que sejam utilizados outros marcadores comuns a ambos os mapas (Grattapaglia \& Sederoff, 1994).

De acordo com Maliepaard \& Van Ooijen, 1994, citados por Maliepaard et al., (1998), ambos os mapas gerados podem ser utilizados separadamente no mapeamento de QTL. Entretanto, como os QTL podem estar presentes em ambos os genitores, é melhor analisá-los com base em um único mapa integrado, com uma abordagem biométrica que possa envolver todos os marcadores. Tendo os marcadores comuns a ambos genitores, não seria preciso realizar a construção de dois mapas, pois, na verdade, o mapa é do cruzamento e deve representar todos os genótipos da população segregante.

Vários trabalhos relatam a possibilidade da integração dos mapas dos dois genitores envolvendo somente marcadores dominantes (Maliepaard et al, 1997; Maliepaard et al., 1998; Seefelder et al., 2000; Yin et al., 2001; Atienza et al., 2002). De acordo com Atienza et al. (2002), para a integração dos grupos homólogos, ou seja, dos grupos formados separadamente por marcadores informativos de cada genitor, devem existir, pelo menos, dois marcadores bi-parentais segregando em cada grupo de ligação, os quais serão utilizados como ponte.

De acordo com Maliepaard (1997), ao considerar a possibilidade de se integrar os mapas dos dois genitores, obtidos a partir de um duplo pseudocruzamento teste envolvendo os marcadores 1:1, através da utilização dos marcadores 3:1, algumas considerações devem ser feitas. Existem três possíveis configurações envolvendo os possíveis pares entre esses marcadores (entenda-se $a, b$ e 0 como alelos de um loco para um marcador):

- Tipo "1": loco 1 ( $a b \times a a)$ X loco 2 ( $a b \times a a)$, ou seja, entre marcadores informativos dentro de um mesmo genitor;

- Tipo "4": loco 1 ( $a b \times a a)$ X loco 2 ( $a 0 \times a 0)$, ou seja, marcador informativo para um dado genitor e um marcador bi-parental, o qual é um loco heterozigótico em ambos genitores; e finalmente 
- Tipo "14": loco $1(a 0 \times a 0) \times$ loco $2(a 0 \times a 0)$, ou seja, configuração envolvendo dois locos bi-parentais.

Há uma grande diferença entre estas configurações quanto ao poder de detecção de ligação. Esta diferença está relacionada à quantidade de informação presente. Para o “tipo 1" a detecção de ligação é realizada sem reservas, mesmo com freqüência de recombinação superior a 0,30, com uma população de 100 indivíduos. Neste caso, está sendo utilizada a estratégia do pseudocruzamento teste propriamente dita, onde os marcadores dominantes são tão informativos quanto os codominantes, pois permitem identificar ambas as classes genotípicas (homozigota e heterozigota) que ocorrem na progênie segregante (Hemmat et al., 1994; Crouzillat et al., 1996). A detecção de ligação, realizada sem problemas, também acontece para o "tipo 14" com freqüências de recombinação superiores a 0,20. Entretanto, para esse tipo de configuração, os locos devem estar em associação nos dois genitores (associação x associação) (Maliepaard et al., 1997).

Considerando a configuração "tipo 4", com uma população de 100 indivíduos, há a necessidade da freqüência de recombinação ser inferior a 0,10, para se conseguir, com mais de $90 \%$ de probabilidade, detectar significância para essa ligação, sendo que este poder de detecção decresce rapidamente quando a freqüência de recombinação aumenta. Esse poder de deteç̧ão é menor para a configuração "tipo 14" quando os locos estiverem em repulsão nos dois genitores (repulsão x repulsão), ficando ainda mais prejudicado quando os locos estiverem em associação em um dos genitores e no outro em repulsão, ou seja, (associação x repulsão) ou (repulsão x associação).

Como não existe informação para estudar a ligação entre locos $a b \times a a$, ou seja, um loco informativo no genitor feminino, e $a a x a b$, informativo para o genitor masculino, para se realizar a integração dos dois mapas, gerados no pseudocruzamento teste, a informação contida nos locos obtidos do cruzamento entre $a 0 \times a 0$, ou seja, locos bi-parentais, deve ser utilizada. Entretanto, a ligação somente será detectada caso o loco bi-parental estiver fortemente ligado aos locos oriundos tanto do cruzamento $a b \times a a$, quanto os do $a a x a b$. Em simulações considerando que as configurações do "tipo 14" 
podem envolver locos em (repulsão x repulsão), (repulsão x associação) ou (associação $\mathrm{x}$ repulsão), a detecção de ligação entre os locos, visando à integração dos mapas, somente foi obtida para freqüências de recombinação iguais a zero, devido ao problema da baixa probabilidade de se encontrar recombinantes visíveis nestas configurações. Dessa forma, a utilização desses marcadores causa imprecisão na estimação nas freqüências de recombinação (Maliepaard et al., 1997).

Um aspecto que, portanto, deve ser abordado é a acurácia dessas estimativas de ligação. Embora se detecte ligação significativa para um determinado par de marcas, isso não implica que a medida da estimativa da freqüência de recombinação seja acurada. Nos processos de mapeamento não há somente a preocupação de se detectar ligação entre os marcadores, mas também estimativas acuradas são necessárias para se determinar a ordem e a distância entre os marcadores. Embora os marcadores $a 0$ x $a 0$ possam ser utilizados para combinar os marcadores $a b$ x $a a$ com os $a a$ x $a b$, seu uso para estabelecer a correta ordem entre esses dois grupos será muito limitado considerando-se pequenas populações.

Os intervalos de confiança para as estimativas de freqüência de recombinação podem ser muito afetadas de acordo com a configuração existente entre os locos. $\mathrm{Na}$ configuração "tipo 1", para uma estimativa de recombinação de 0,10 entre locos, envolvendo uma população de 100 indivíduos, o intervalo, com 95\% de confiança, é de $[0,05 ; 0,18]$. Para a configuração do "tipo 4 " o intervalo é de $[0,02 ; 0,28]$ e para o "tipo 14" ( $a$ x $a$ - ou seja, os dois locos em associação nos dois genitores) o intervalo é de $[0,04 ; 0,19]$. De forma similar, intervalos de $[0,02 ; 0,32]$ e $[0,01 ; 0,44]$ são encontrados para configurações do "tipo 14" (associação x repulsão) e (repulsão x repulsão), respectivamente. Portanto, a amplitude desses intervalos de confiança indica claramente a dificuldade que pode ser esperada para se ordenar marcadores dominantes. Embora marcadores bi-parentais $(a 0 \times a 0)$ possam também ser utilizados para combinar os marcadores $a b \times a a$ e $a a \times a b$, seu uso em estabelecer a correta ordem entre os marcadores será muito limitado ao se considerar pequenas populações. 
Ainda segundo o texto de Maliepaard et al. (1997), antes da detecção de ligação, a determinação da fase de ligação entre as marcas deve ser determinada. Considerando simulações, a escolha da fase de ligação, com base em um "LOD score" significativo e a estimativa da freqüência de recombinação foram obtidas corretamente para quase todas as configurações entre marcadores envolvendo populações com tamanhos superiores a 50 indivíduos. Entretanto, em algumas situações, a obtenção das fases não pode ser determinada, sendo portanto necessária a utilização de marcadores mais informativos, pois tendo "LOD scores" não significativos, não há confiabilidade na escolha da fase de ligação. Do ponto de vista teórico, é interessante o desenvolvimento de um procedimento que estime simultaneamente a freqüência de recombinação e a fase de ligação para todos os marcadores. Entretanto, os resultados serão redundantes com os que não apresentaram problemas nas simulações.

$\mathrm{Wu} \& \mathrm{Ma}$ (2002) descrevem uma metodologia que estima, simultaneamente, as ligações e as fases. Entretanto, não há, ainda, um programa computacional que realize estas análises.

\subsection{Detecção e Mapeamento de QTL}

\subsubsection{Base Genética}

Uma razão pelo interesse de alocar um QTL é a de fornecer meios para se responder algumas questões fundamentais sobre o controle genético das características quantitativas. Quantos locos são? São muitos, como sugerido para produtividade, ou são apenas poucos genes de maior efeito segregando, enquanto os demais são pequenos e sem importância? Como estes genes estão distribuídos no genoma? Eles são localizados em um determinado cromossomo ou distribuídos ao acaso? Ao considerar estas questões, deve-se ter em mente que em cada cruzamento, ou população sob estudo, somente alguns genes estarão segregando para determinada característica. Embora existam potencialmente centenas de genes que possam afetar a produtividade, somente 
uma pequena porção pode estar segregando em determinada instância. A genética quantitativa pode nada resolver considerando locos monomórficos, pois não contribuem para a variação (Kearsey \& Pooni, 1996).

O mapeamento de genes de resistência por meio de marcadores moleculares tem contribuído decisivamente para um melhor entendimento sobre as bases genéticas da resistência de plantas a fitopatógenos. O uso de marcadores possui como objetivo primário a caracterização fenotípica dos diversos genes de resistência que podem estar segregando em um dado cruzamento e utilizar esta informação para escolher, dentre os vários, quais possuem efeitos fenotípicos desejáveis e que, portanto, são bons candidatos a serem selecionados (Camargo, 2001).

Uma grande aplicação dos marcadores moleculares é no estudo das bases genéticas das resistências ditas poligênicas. Os marcadores permitem individualizar o efeito fenotípico de cada poligene e acompanhar a sua segregação, como se fossem fatores genéticos discretos (Lander \& Botstein, 1989). Esta separação é a que ficou informalmente chamada de "mendelização" de características poligênicas (Camargo, 2001). Tais fatores genéticos são denominados de QTL ou, no caso específico de locos de resistência a doenças, de QRL, siglas estas já utilizadas nesta revisão.

Através dos métodos de detecção da ligação entre um QTL e o marcador molecular, pode-se também mensurar os efeitos dos QTL que controlam o caráter em estudo, investigando, assim, a arquitetura das características quantitativas, ou seja, o número, a posição, a ação gênica, a magnitude de efeito e as interações entre QTL (Melo, 2000).

As técnicas empregadas para a estimação dos efeitos e das posições de QTL são extensões dos métodos clássicos para o mapeamento de genes qualitativos e exigem desequilíbrio de ligação entre os alelos do loco marcador e o QTL. Os requerimentos para mapeamento de QTL são, portanto, (i) um mapa de ligação de marcadores polimórficos que cubra adequadamente o genoma, e (ii) variação para a característica quantitativa entre ou dentro da população (Falconer \& Mackay, 1996). 
O princípio usado para identificação do QTL pela ligação ao loco marcador é conceitualmente simples: os indivíduos são classificados quanto ao seu genótipo molecular e o seu fenótipo para a característica quantitativa. Como dito, a detecção de ligação genética entre marcadores e QTL depende da existência de desequilíbrio de ligação, entre os alelos do loco marcador e do QTL, o qual gera efeitos quantitativos associados ao marcador, que podem ser detectados e estimados por meio de análises estatísticas adequadas. Se existe diferença entre as médias dos fenótipos referentes às classes de marcas moleculares, então se pode inferir que há um QTL ligado ao marcador (Falconer \& Mackay, 1996).

O fenótipo de um indivíduo não é condicionado apenas pelo genótipo, mas também pela interação genótipo x ambiente. Isto sugere que um QTL importante em um ambiente pode não ser tão importante em outro ambiente. Quando os genótipos são avaliados em mais de um ambiente, existe a possibilidade de identificar e estimar o efeito da interação genótipos por ambientes, sendo considerados como diferentes ambientes, principalmente, os vários locais, anos e épocas de cultivo em que os genótipos são avaliados. Stuber et al. (1992), em estudos com milho, envolvendo sete caracteres agronômicos, em uma mesma população, em seis diferentes ambientes, relatam que QTL detectados em um ambiente foram, freqüentemente, detectados em outros ambientes, sugerindo uma pequena interação QTL por ambientes.

Falconer \& Mackay (1996) afirmam que as estimativas do número de QTL são estimativas mínimas do verdadeiro número de locos que afetam a característica. Segundo os autores, isto é devido a três razões: (i) os experimentos possuem limitado poder de separação de locos proximamente ligados, podendo dessa forma se apresentar como se fossem um único loco, se em associação, ou não serem detectados se estiverem em repulsão; (ii) existência de outros locos com efeitos tão pequenos para serem detectados por um experimento de um tamanho particular e (iii) os locos encontrados foram devidos às diferenças genéticas entre os dois indivíduos envolvidos no cruzamento, sendo possível encontrar mais locos em outros cruzamentos. 
Como são utilizadas técnicas estatísticas para verificar a ligação entre o QTL e o marcador, Coelho \& Silva $(2002)^{7}$ relatam que nesse procedimento se está sujeito ao erro Tipo I que, no caso, equivale à identificação de um QTL inexistente, também chamado QTL “fantasma”. Desse modo, a afirmação de Falconer \& Mackay (1996) pode nem sempre ser verdadeira. Da mesma forma, vale relatar que o erro Tipo II referese a não se considerar a presença de um QTL em um local onde o mesmo realmente exista (Jansen, 1994).

O tamanho da população segregante e o número de marcadores polimórficos utilizados assume grande importância neste tipo de análise.

Coelho (2000) relata que o número de indivíduos genotipados estabelece o nível de resolução máximo que pode ser alcançado com um número ilimitado de marcadores no mapa genético. A influência do número de marcadores genéticos utilizados, por outro lado, está relacionada ao quanto da resolução preestabelecida pelo número de indivíduos genotipados será de fato realizada. Tanto o grau de cobertura do genoma quanto a densidade do mapa a ser construído são funções diretas do número de marcadores utilizados. Assim, aumentando-se o número de marcadores espera-se que o mapa fique mais saturado, tornando maiores as chances de se encontrar QTL mais próximos aos marcadores. Segundo Grattapaglia (2000), progênies de tamanho muito grandes teriam que ser geradas para se obter uma probabilidade razoável de recuperar os genótipos com combinações favoráveis de alelos na maioria dos QTL de interesse.

O tamanho da população utilizada depende da precisão desejada e do tipo de característica a ser mapeada: geralmente 50 a 100 indivíduos constituem a população para a construção do mapa genético de uma espécie. Outro fator importante é o tipo de população segregante e as características do marcador. Melhores resultados são obtidos com populações $F_{2}$ e marcadores codominantes (RFLP ou microssatélites) devido ao menor grau de distorção da freqüência dos alelos associado ao conhecimento completo

\footnotetext{
${ }^{7}$ COELHO, A.S.G.; SILVA, H.D. Construção de mapas genéticos e mapeamento de QTL's. Piracicaba, 2002. 65 p. (apostila).
} 
do genótipo (distinção entre heterozigoto e homozigoto) dos indivíduos em cada loco (Souza, 2001).

A precisão da localização do QTL depende mais do tamanho da população utilizada que da densidade de marcadores utilizados. A eficiência de todos os métodos será maior quanto maior for o tamanho populacional e a herdabilidade da característica a ser analisada (Kearsey \& Pooni, 1996).

Alguns mapas chegam a ter apenas poucos centimorgans (cM) entre os marcadores. Entretanto, o que é encontrado como um QTL é um segmento de cromossomo com essas distâncias, o qual pode conter um ou mais locos afetando a característica, não necessariamente na mesma direção. Portanto, é mais desejável que muitos QTL sejam detectados quando os alelos estão em associação comparativamente quando em repulsão (Falconer \& Mackay, 1996).

Preferentemente, todos os alelos deveriam estar em associação, ou seja, os alelos favoráveis para uma determinada característica deveriam estar em homozigose em um determinado genitor, e os alelos desfavoráveis fixados no outro genitor. Homozigose e o arranjo de QTL em associação são mais fáceis de serem encontrados se os genitores forem resultado de seleção artificial divergente para a característica de interesse, e tenham sido cruzados subseqüentemente. Se cada linhagem possui alguns alelos favoráveis ou desfavoráveis fixados, os alelos estão em repulsão; nestas circunstâncias ainda é possível localizar QTL, mas com menos chance do que seriam encontrados caso estivessem em associação.

Ainda segundo o texto de Falconer \& Mackay (1996), em muitos estudos, QTL com grandes efeitos aditivos têm sido detectados, sendo que nem todos possuem o mesmo efeito. Um padrão encontrado para diferentes características demonstra que poucos QTL de grande efeito explicam a divergência entre as linhagens genitoras, com um grande número de QTL de menores efeitos que explicam o restante da diferença.

QTL com efeitos maiores têm sido identificados para a grande parte dos caracteres estudados, mas a maioria é de pequeno efeito, pois considera-se que a maioria 
dos genes segregantes numa população, provavelmente, tenha algum pequeno efeito sobre outros caracteres. Este pequeno efeito de um QTL pode ainda ser detectado pelos marcadores dependendo de alguns fatores: (i) distância entre marcador e QTL, pois quanto mais próximos estiverem, menor será a recombinação e, portanto, mais robusto é este marcador; (ii) tamanho da população segregante (quanto maior a população, maior a probabilidade de detecção de QTL com menor efeito fenotípico); (iii) herdabilidade do caráter (quanto maior o efeito do ambiente em um caráter, isto é, menor a herdabilidade, menor a probabilidade de um QTL de grande efeito ser detectado); (iv) nível de probabilidade de erro usado para declarar um efeito do QTL como significativo, pois quanto mais alta a precisão exigida, menor será a chance de identificar QTL de efeito menor (Melo, 2000).

Embora estimativas de herdabilidade de uma característica sejam específicas para materiais genéticos e ambientes distintos, estes valores podem ser úteis para fornecer uma pista inicial. Intuitivamente, a probabilidade da existência de genes de maior efeito para características de baixa herdabilidade é menor do que para características de herdabilidade alta. Porém isto não pode ser usado com parâmetro para descartar possíveis experimentos de mapeamento de QTL. Mesmo com baixa herdabilidade, as características ainda poderiam exibir QTL de maior efeito, podendo, portanto fazer com que a seleção assistida por marcadores tenha maior impacto (Grattapaglia, 2001).

\subsubsection{Métodos de Mapeamento}

A associação entre marcador e QTL pode ser avaliada utilizando-se uma, duas ou mais marcas simultaneamente. Na análise de marcas simples, a distribuição dos valores do caráter é examinada separadamente para cada marcador. Assim, cada teste é realizado independentemente da informação dos outros locos e, deste modo, um cromossomo com $t$ marcas fornece $t$ testes de marcas simples. Esse tipo de análise é, geralmente, uma boa 
opção quando o objetivo é simplesmente a detecção de QTL ligados à marca em detrimento da estimação da posição e dos efeitos do mesmo (Coelho \& Silva, 2002) ${ }^{8}$.

As análises de marcas simples não apresentam aspectos computacionais complicados e não é necessário o conhecimento da posição dos marcadores no genoma (mapa de marcadores) (Coelho \& Silva, 2002) ${ }^{7}$. Entretanto, Liu (1998) cita as seguintes desvantagens: (i) o efeito de um determinado QTL fica confundido com sua localização, ou seja, não é possível distinguir um QTL de pequeno efeito, situado muito próximo ao marcador de um QTL de grande efeito, situado mais distante; (2) a posição do QTL não pode ser precisamente determinada, devido à não independência entre os testes de hipóteses para ligação, que confundem o efeito do QTL e sua posição.

O método da máxima verossimilhança para análise de marcas simples foi apresentado por Weller (1986), sendo que uma de suas grandes vantagens é a de estimar a posição do QTL, separando a freqüência de recombinação $(c)$ dos efeitos aditivos $(a)$ e de dominância $(d)$.

O mapeamento por intervalo, proposto por Lander \& Botstein (1989), é uma extensão do método de máxima verossimilhança para marcas simples, sendo implementado com base nas freqüências conjuntas de um par de marcas adjacentes e um QTL pontual, flanqueado por essas duas marcas. As análises são realizadas considerando cada par de marcas adjacentes, resultando, então, em $t-1$ testes de associação QTL/marcador por cromossomo com $t$ marcas (um teste para cada intervalo). Essa metodologia de mapeamento oferece um incremento no poder de detecção de QTL e estimativas mais precisas da posição e dos efeitos do mesmo.

A máxima vantagem da análise por intervalo sobre a análise por marcas simples ocorre quando marcadores ligados estão razoavelmente separados $(>20 \mathrm{cM})$. Nestas condições, provavelmente, existirão algumas permutas entre os marcadores e o QTL, que podem ser compensadas pela análise por intervalo. Segundo Stuber et al. (1992), quando a densidade de marcadores é alta $(<15 \mathrm{cM})$, as análises por ponto ou intervalo

\footnotetext{
${ }^{7}$ COELHO, A.S.G.; SILVA, H.D. Construção de mapas genéticos e mapeamento de QTL's. Piracicaba, 2002. 65 p. (apostila).
} 
dão resultados praticamente idênticos. Quando os locos marcadores são muito distantes ( $>35 \mathrm{cM})$, constantemente a análise por intervalo se mostra ineficiente para detectar QTL no intervalo entre dois locos marcadores. De acordo com Ferreira \& Grattapaglia, (1996), qualquer que seja a abordagem estatística, o mapeamento de intervalos clássico sofre um problema de resolução quando dois QTL estão ligados no mesmo cromossomo.

Tanto o mapeamento por intervalo quanto às análises de marcas simples são viesadas quando múltiplos QTL estão ligados ao intervalo/marca considerado. Uma desvantagem atribuída ao mapeamento por intervalo clássico é a de que os outros QTL fora do intervalo em questão são ignorados. Isso pode ter duas conseqüências principais. Toda a variação genética devida a estes outros QTL é residual, o que pode diminuir a precisão das estimativas e o poder dos testes. Além disso, eventuais QTL que estejam ligados ao intervalo em questão interferem no processo de estimação. Caso ambos possuírem o mesmo sinal, ou seja, estiverem em associação, pode-se, em casos extremos, se declarar a existência de um QTL, quando na realidade não há nenhum QTL presente (erro Tipo I). Por outro lado, caso estes QTL estejam em repulsão, ou seja, com sinais opostos, se neutralizando, o método por intervalo não irá detectar esses QTL (erro Tipo II) (Jansen, 1994; Bearzoti, 2000).

Em vista disso, Jansen (1993; 1994), Jansen \& Stam (1994) e Zeng (1994) propuseram uma estratégia que combina, em um único modelo, técnicas de mapeamento, por intervalo e regressão múltipla, com o método da máxima verossimilhança, no intuito de eliminar as influências de outros QTL sobre o intervalo considerado. A denominação proposta por Zeng (1994) foi a de mapeamento por intervalo composto (Composite Interval Mapping - CIM), enquanto a proposta por Jansen $(1993$; 1994) e Jansen \& Stam (1994) foi de mapeamento múltiplo de QTL (Multiple QTL Models - MQM).

O enfoque desse tipo de mapeamento é de impedir que QTL adjacentes, com algum marcador entre eles, interfiram nos valores estimados em cada intervalo. Já quando existem dois QTL adjacentes, sem marcadores entre eles, a eliminação dessa interferência não é possível. No entanto, em mapas saturados (pequenas distâncias entre 
marcas adjacentes), a probabilidade de ocorrência de QTL adjacentes é muito baixa (Melo, 2000; Bearzoti, 2000; Coelho \& Silva9 , 2002).

Para caracteres poligênicos, existem interações epistáticas envolvendo dois, três ou mais locos. Nos estudos de genética quantitativa, a variância genética atribuída à epistasia tem sido freqüentemente referida como interação genótipo por genótipo. No passado, raramente, era possível determinar se tais interações ocorriam entre poligenes específicos ou medir precisamente a natureza específica desta interação. Tanksley (1993) relata que a disponibilidade de mapas e de QTL individualmente caracterizados, via técnicas de mapeamento molecular, aumentou as possibilidades de detecção e caracterização das interações entre QTL específicos. A significância dessa interação sugere que o efeito devido a vários QTL não é simplesmente a soma de seus efeitos independentes.

A metodologia denominada de mapeamento por intervalos múltiplos (Multiple Interval Mapping - MIM), apresentada por Kao et al., (1999), pode levar a um aumento na precisão e no poder da detecção de QTL, além de permitir a estimação e análise dos efeitos de interação entre QTL (epistasia). Segundo Melo (2000), esse é um método múltiplo, pois simultaneamente busca estimativas de número, posições, efeitos e interações entre diferentes QTL. As vantagens dessa metodologia são maior eficiência e precisão na identificação de QTL; ajuda a entender e identificar padrões epistáticos; os efeitos dos QTL são estimados sem viés, na presença de epistasia, ao contrário dos outros métodos; pode aumentar a eficiência da seleção assistida por marcadores, pois capitaliza os efeitos epistáticos entre os QTL.

Vale relatar que qualquer fenótipo mensurável é, em princípio, sensível a análises de QTL. Para uma característica quantitativa há potencialmente muitos genes contribuindo para essa variação (Yin et al., 2002). Entretanto, o número de QTL para uma característica, detectado com as abordagens existentes de mapeamento, raramente é superior a oito, pois dependendo do tamanho da população de mapeamento, um grande

\footnotetext{
${ }^{9}$ COELHO, A.S.G.; SILVA, H.D. Construção de mapas genéticos e mapeamento de QTL's. Piracicaba, 2002. 65 p. (apostila).
} 
número de QTL possuem efeitos inferiores ao limiar de significância (Kearsey \& Farquhar, 1998).

\subsubsection{Mapeamento de QTL em populações $F_{1}$}

Para as análises de QTL vale relatar que o delineamento genético utilizando dois genitores heterozigóticos $\left(\mathrm{F}_{1}\right)$ possui duas limitações. Primeiro, os únicos QTL que podem ser potencialmente detectados são aqueles que, por acaso, encontram-se em heterozigose nos genitores do cruzamento e quando o efeito diferencial entre alelos alternativos aos QTL seja relativamente grande para permitir detecção estatística com o tamanho amostral da progênie disponível. Em segundo lugar, devido à possível heterozigosidade dos locos QTL em ambos os genitores, e o fato do polimorfismo ser de dose única e herança dominante, nenhuma interação intraloco específica pode ser levada em consideração e nenhuma classificação (ranking) de alelos por magnitude de efeito de substituição pode ser realizada. Esta situação de informação genética incompleta pode resultar em erros Tipo I e II na detecção de QTL e estimativa imprecisa de magnitude do efeito de QTL. Este fato sugere claramente que somente marcadores multialélicos codominantes permitirão o rastreio, compreensão e manipulação adequada de toda a variabilidade alélica que segrega aos QTL (Grattapaglia, 2001).

Esta estratégia serve, portanto, para a realização de estudos envolvendo o cruzamento entre indivíduos heterozigóticos, dentro de diferentes espécies. A detecção e expressão de QTL, que controlam características quantitativas, irá depender dos "backgrounds" genéticos envolvidos no cruzamento, pois a expressão de um determinado alelo de QTL proveniente de um dos genitores na progênie irá variar de acordo com o conjunto genético existente, ou seja, dependerá do genótipo do outro genitor envolvido. O fato de os QTL não detectados em um primeiro cruzamento serem detectados em outro, pode ser explicado por, pelo menos, três maneiras: os genitores do primeiro cruzamento serem efetivamente ou funcionalmente homozigóticos para o QTL, 
de forma que nenhuma diferença estatística entre os alelos poderia ser detectada; pela óbvia hipótese de multialelismo dos QTL; esses resultados sejam decorrentes de expressão dependente do genoma (epistasia) e do efeito amostral (Grattapaglia, 2001).

Algumas considerações, igualmente às relatadas para a cultura do eucalipto (Grattapaglia, 2001), podem, portanto, serem feitas para a cultura do maracujazeiro. A associação de um alelo a um QTL, detectado em determinado cruzamento, pode não ser o melhor alelo que existe na população de melhoramento, pois outros alelos de efeito igual ou até melhor muito provavelmente existam. Como o processo de domesticação de populações de maracujazeiros é extremamente recente, há uma grande variabilidade alélica ainda presente para ser explorada. Portanto, a seleção assistida por marcadores dependerá da capacidade de se descobrir, mapear e medir a magnitude do efeito dos alelos existentes dos QTL de maior efeito em populações de melhoramento. Somente através da alteração das freqüências dos alelos de grande efeito relativos aos QTL mais relevantes é que a seleção assistida por marcadores suplantará a seleção fenotípica convencional e será, de fato, útil para o melhoramento genético. 


\section{MATERIAL E MÉTODOS}

\subsection{Material}

Este trabalho representa uma continuação dos estudos realizados por Lopes (2003) que realizou o primeiro trabalho de mapeamento de QRL para Xanthomonas axonopodis pv. passiflorae, em maracujá-amarelo, utilizando marcadores moleculares com base no polimorfismo de comprimento de fragmentos amplificados (AFLP), em uma população de indivíduos $\mathrm{F}_{1}$, geneticamente segregante.

A população segregante foi originalmente obtida por Carneiro et al. (2002), a partir de um cruzamento simples entre dois acessos de Passiflora edulis Sims f. flavicarpa Deg. pertencentes ao Lote de Introdução e Seleção de Materiais do Instituto Agronômico do Paraná (IAPAR), Londrina - PR. Os acessos foram o IAPAR-123, usado como genitor feminino, apresentando boas características agronômicas além de ser considerado resistente a Xanthomonas axonopodis pv. passiflorae, e o IAPAR-06, genitor masculino, que é uma introdução do Marrocos, apresentando características agronômicas inferiores às do acesso IAPAR-123 e tido como susceptível à moléstia. Estes contrastes fenotípicos indicaram a possibilidade de detecção de polimorfismos moleculares entre os genitores os quais, de fato, foram obtidos e permitiram a construção de um mapa de ligação com base em marcadores RAPD (Carneiro, 2001). 


\subsection{Métodos}

\subsubsection{Inoculação do isolado patogênico}

No trabalho realizado por Lopes (2003) foi estabelecido que cada planta corresponderia a uma parcela, sendo que três folhas foram inoculadas por planta. $\mathrm{O}$ valor fenotípico de cada parcela era formado pela média dos valores das áreas lesionadas das três folhas. Por essa estratégia, não foi possível verificar se havia diferença entre as lesões, devido ao efeito da idade das folhas. Portanto, novos estudos eram necessários para verificar a existência ou não dessa diferença, quanto à influência da idade das folhas na severidade da bacteriose.

Grattapaglia (2001) relata que é esperado obter interações QTL x ambiente ao se considerar a presença de interação genótipo $\mathrm{x}$ ambiente, sendo esta expectativa também válida ao considerar diferentes épocas de avaliação que favorecem a detecção dessas interações.

Nos trabalhos realizados por Nakatani (2001) e Lopes (2003), as mensurações das lesões bacterianas foram realizadas aos 20 dias após a inoculação, não sendo possível saber, por exemplo, se a severidade avaliada aos 20 dias, seria igual à apresentada em outras datas. Portanto, foram realizados estudos para se detectar os efeitos da interação data de mensuração x genótipos, com mensurações realizadas a cada dois dias.

\subsubsection{Primeiro experimento}

Para avaliação de resistência à bacteriose, 104 indivíduos da população segregante, juntamente com os genitores IAPAR-06 e IAPAR-123, foram submetidos à inoculação com o isolado "1", oriundo da região de Vera Cruz - SP e o isolado "18b", oriundo da região de São Miguel Arcanjo - SP. Estes isolados de Xanthomonas 
axonopodis pv. passiflorae são oriundos da coleção de bactérias pertencente ao Laboratório de Genética Molecular do Departamento de Entomologia, Fitopatologia e Zoologia Agrícola da ESALQ/USP, que está preservada em glicerol sob $-80{ }^{\circ} \mathrm{C}$.

Esses isolados foram utilizados no presente estudo por terem se destacado quanto à agressividade da moléstia, em maracujazeiro-amarelo, no trabalho realizado por Nakatani (2001). O isolado "18b" além de ser agressivo, permitiu uma melhor discriminação entre os genitores IAPAR-06 e IAPAR-123, segundo Lopes (2003). A utilização desse isolado tornou possível verificar se há interação QRL x ambiente, já que o mesmo já havia sido utilizado por Lopes (2003), em avaliação anterior, no mesmo local e época do ano que os do presente estudo, em 2001.

As plantas utilizadas foram obtidas por estaquia a partir da população segregante, mantida isolada em casa de vegetação. Os genótipos estão relatados na Tabela 1.

Tabela 1. População segregante. Indivíduos utilizados para inoculação com isolados de Xanthomonas axonopodis pv. passiflorae e identificados com o seguinte código: os números fora dos parênteses se referem aos frutos obtidos do cruzamento e os números dentro dos parênteses se referem às mudas obtidas, a partir de sementes, do respectivo fruto ${ }^{1 /}$

\begin{tabular}{|c|c|c|c|c|c|c|c|c|c|}
\hline IAPAR - 06* & $4(2)^{*}$ & $8(4)^{*}$ & $12(6)$ & $13(9)^{*}$ & $17(15)$ & $17(33)$ & $18(2)$ & $\mathrm{III}(6)$ & $\mathrm{XV}(4)$ \\
\hline IAPAR - $123^{*}$ & $4(5)^{*}$ & $8(8)^{*}$ & $12(9)$ & $14(1)^{*}$ & $17(17)^{*}$ & $17(34)^{*}$ & $18(5)$ & $\mathrm{III}(7)^{*}$ & $\mathrm{XV}(5)$ \\
\hline $1(3)^{*}$ & $4(7)^{*}$ & $9(1)$ & $12(10)^{*}$ & $15(2)$ & 17(18)* & $17(35)$ & $18(7)$ & $\operatorname{III}(8)^{*}$ & $X V(7)^{*}$ \\
\hline $2(1)^{*}$ & $5(2)^{*}$ & $9(3)^{*}$ & $12(13)^{*}$ & $17(1)^{*}$ & $17(22)^{*}$ & $17(36)^{*}$ & $19(1)$ & III(10) & $\mathrm{XV}(8)^{*}$ \\
\hline $2(3) *$ & $5(4) *$ & $9(4)^{*}$ & $12(15)^{*}$ & $17(2)^{*}$ & $17(23)$ & $17(37)^{*}$ & $20(1)^{*}$ & $\operatorname{III}(11)^{*}$ & $X V(10)$ \\
\hline $2(5) *$ & $5(5)^{*}$ & $8(10)^{*}$ & $12(17)$ & $17(3)^{*}$ & $17(24)$ & $17(38) *$ & $21(1)^{*}$ & III(12) & $X V(11)$ \\
\hline $2(7)^{*}$ & $6(1)^{*}$ & $8(12)^{*}$ & 12(19)* & $17(4)$ & $17(26)^{*}$ & $17(39) *$ & $21(5)^{*}$ & $\operatorname{III}(13)^{*}$ & $X V(12)$ \\
\hline $3(6)^{*}$ & $6(3)^{*}$ & $8(13)$ & $12(20)$ & $17(6)$ & $17(28)^{*}$ & $17(40)$ & $\operatorname{III}(2)^{*}$ & $\operatorname{III}(16)^{*}$ & \\
\hline $3(10)^{*}$ & $7(1)$ & $10(5)^{*}$ & $12(23)^{*}$ & $17(7)$ & $17(29)$ & $17(41)^{*}$ & $\operatorname{III}(3)^{*}$ & III $(17)^{*}$ & \\
\hline $3(12)^{*}$ & $8(1)^{*}$ & $11(1)^{*}$ & $13(3)^{*}$ & $17(8)$ & $17(30)^{*}$ & $17(42)^{*}$ & $\operatorname{III}(4)^{*}$ & $\operatorname{III}(18)^{*}$ & \\
\hline $3(13)$ & $8(2)^{*}$ & $12(2)^{*}$ & $13(8)$ & $17(11)^{*}$ & $17(31)$ & $17(43)^{*}$ & $\operatorname{III}(5)$ & $\mathrm{XV}(2)^{*}$ & \\
\hline
\end{tabular}

O estaqueamento foi realizado em $26 / 10 / 2002$, sendo colocadas duas estacas em cada copo plástico transparente para, dessa forma, favorecer a visualização do desenvolvimento das raízes. Foi utilizado como substrato o condicionador de solo comercial PLANTMAX - HORTALIÇAS HA (Eucatex Química e Mineral Ltda.). 
Para a obtenção dos clones, foi levado em consideração o local de retirada de cada estaca, pois como as plantas matrizes estavam bem desenvolvidas, os ramos estavam grandes e fortes, podendo, portanto, fornecer estacas com diferentes características de desenvolvimento (Salomão et al., 2002). Foram formados três grupos: a) estacas apicais, ou seja, da ponteira do ramo, que é uma região mais tenra; b) estacas de regiões medianas do ramo e c) estacas provenientes de regiões basais, ou seja, de partes mais lenhosas. Essa estratégia foi utilizada para a obtenção de mudas mais uniformes.

Após apresentarem raízes bem desenvolvidas, foi realizado o plantio definitivo em 12/12/2002. As mudas foram transplantadas para sacos plásticos de polietileno $20 \mathrm{x}$ $25 \mathrm{~cm}$, tendo como substrato uma mistura, em partes iguais, do condicionador de solo comercial PLANTMAX $^{\circledR}$ com terra de barranco peneirada.

Para todos os genótipos, as mudas obtidas das regiões medianas do ramo foram escolhidas para inoculação por terem apresentado um desenvolvimento mais vigoroso e uniforme. A transferência para o telado de inoculação foi realizada em 28/02/2003.

As plantas foram tutoradas com hastes de bambus, de forma a possibilitar crescimento vertical, o que favoreceu um melhor arranjo das parcelas no experimento e permitiu melhor controle químico de pragas e doenças. Além disso, essa forma de tutoração foi muito importante devido ao tamanho do telado de inoculação e o número de plantas utilizadas (Figura 2). No período em que estiveram no telado, ocorreram ataques de septoriose (Septoria passiflorae), ácaro vermelho (Tetranychus mexicanus) e de uma joaninha amarela, a qual se alimentava das folhas mais jovens. Para o controle da septoriose, foi aplicado o fungicida sistêmico Benlate ${ }^{\circledR} 500$ (Du Pont $\left.{ }^{\circledR}\right)$, grupo químico benzimidazol, com dosagem $3,5 \mathrm{~g} / 5 \mathrm{~L}$, aplicado 10 dias antes da inoculação. Para o controle dos ácaros e demais insetos foi aplicado o produto comercial Azodrin 400 (Cyanamid Química do Brasil Ltda.), um inseticida e acaricida do grupo dos organofosforados, com a dose 1,0 mL/litro, sendo este aplicado conforme a necessidade, mesmo após a inoculação. 

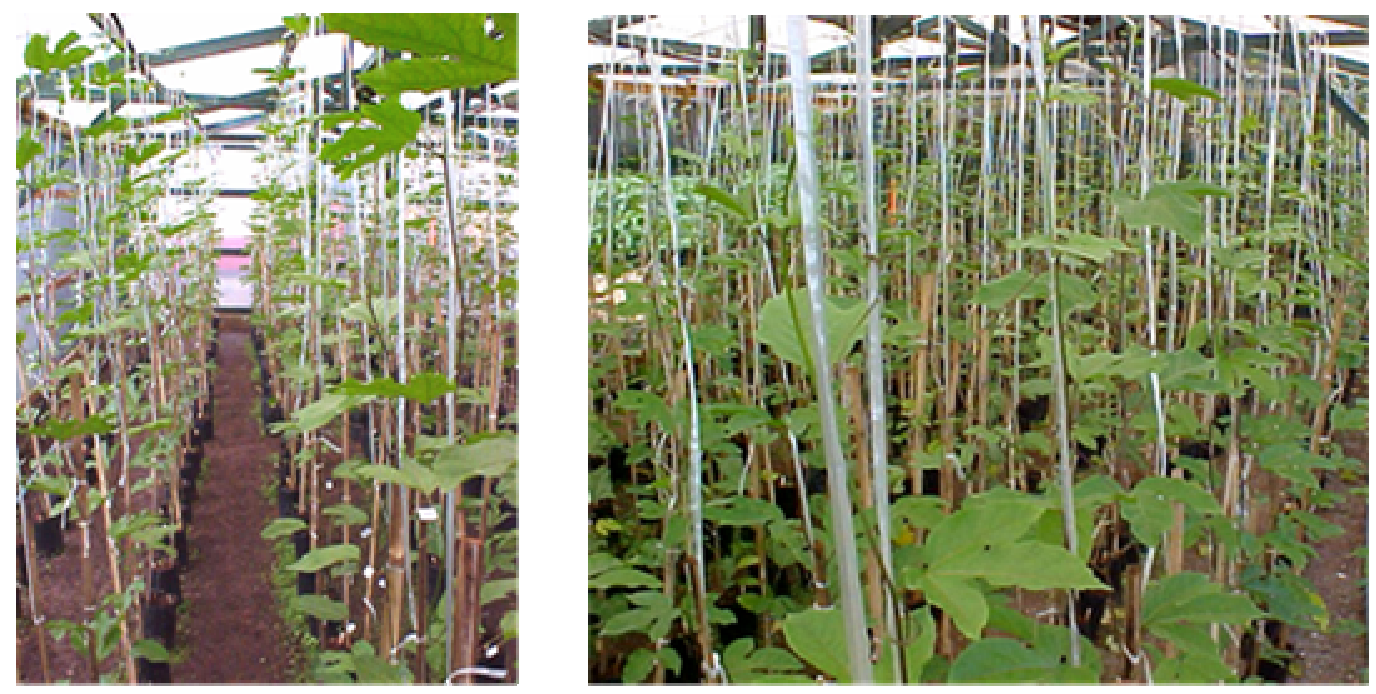

Figura 2 - A) Mudas tutoradas verticalmente; B) Vista geral demonstrando elevado número de plantas no interior do telado de inoculação, após 100 dias do plantio definitivo

As adubações foram realizadas semanalmente, com $40 \mathrm{~mL}$ por planta do adubo químico Ouro Verde ${ }^{\circledR}$ (Empresa Paulista de Produtos Químicos - EPPQ Ltda.), composição 15-15-20, com macronutrientes secundários e micronutrientes, com dosagem de $30 \mathrm{~g}$ dissolvidos em $8 \mathrm{~L}$ de água.

Durante o período que as mudas estiveram no telado de inoculação, dados de desenvolvimento das plantas, como velocidade de crescimento, número de folhas, distância dos entrenós das folhas inoculadas, diâmetro dos ramos, tamanho de pecíolo e a pigmentação de ramos e gavinhas foram obtidos (dados não apresentados). $\mathrm{O}$ experimento foi conduzido em uma casa de vegetação com 5,30 m x 9,90 m que foi, longitudinalmente, dividido em três blocos. Foi colocado um termômetro em cada bloco para verificar a homogeneidade de temperaturas nos blocos, durante o passar do dia. Dados de temperatura foram tomados às 08:00, 12:00, 16:00 e 18:30. Na região central do telado, a uma altura de $2 \mathrm{~m}$, foi colocado um higrômetro para se medir a umidade. As folhas inoculadas estavam a uma altura média de 1,0 m.

Tomou-se cuidado para evitar erros de avaliação, garantindo que o valor da lesão mensurada refira-se ao respectivo genótipo. Esse tipo de problema poderia ocorrer 
eventualmente após a queda das folhas ou durante seus destacamentos para as mensurações. Cada folha foi identificada por bloco de avaliação, genótipo avaliado e posição na planta (Figura 3).

Por exemplo, considere o segundo contorno da curva, realizado em uma segunda oportunidade de mensuração: caso uma folha tenha caído, por motivos diversos, como a senescência, os dados obtidos até então (contornos) poderiam ser coletados, com a simples digitalização da folha destacada, com o auxílio de um "scanner".
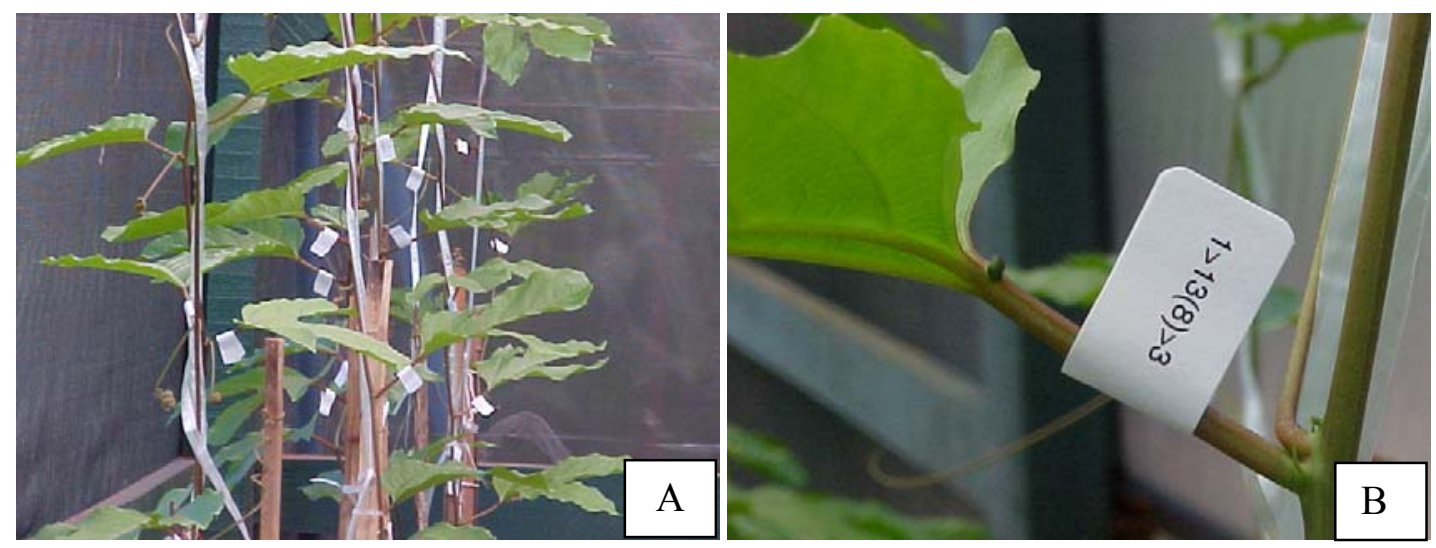

Figura 3 - A) Identificação das folhas inoculadas; B) Forma de identificação adotada na etiqueta: primeira repetição, indivíduo 13 (8), folha 3

Tendo as mudas se adaptado ao novo local, apresentando pleno crescimento, o telado de inoculação teve suas paredes cobertas com plástico em 16/03/2003, em toda sua superfície (Figura 4). Dois dias antes da inoculação, realizada em 20/03/2003, o piso, de terra batida, e as laterais do telado foram excessivamente irrigadas com o auxílio de uma mangueira, possibilitando a formação de um ambiente úmido e abafado, propício para um melhor desenvolvimento da bacteriose (Figura 5). As plantas foram irrigadas diretamente no pé, evitando-se molhar as folhas. Em intervalos de sete dias, as folhas também eram irrigadas de forma a lavar a poeira que se acumulava, facilitando a demarcação do crescimento das lesões. 
Esse método de irrigação foi utilizado no intuito de evitar o acúmulo diário de água nas folhas, fato este que contribuiu para perdas de parcelas no trabalho realizado por Lopes (2003). O higrômetro determinava a necessidade da realização de novas irrigações.

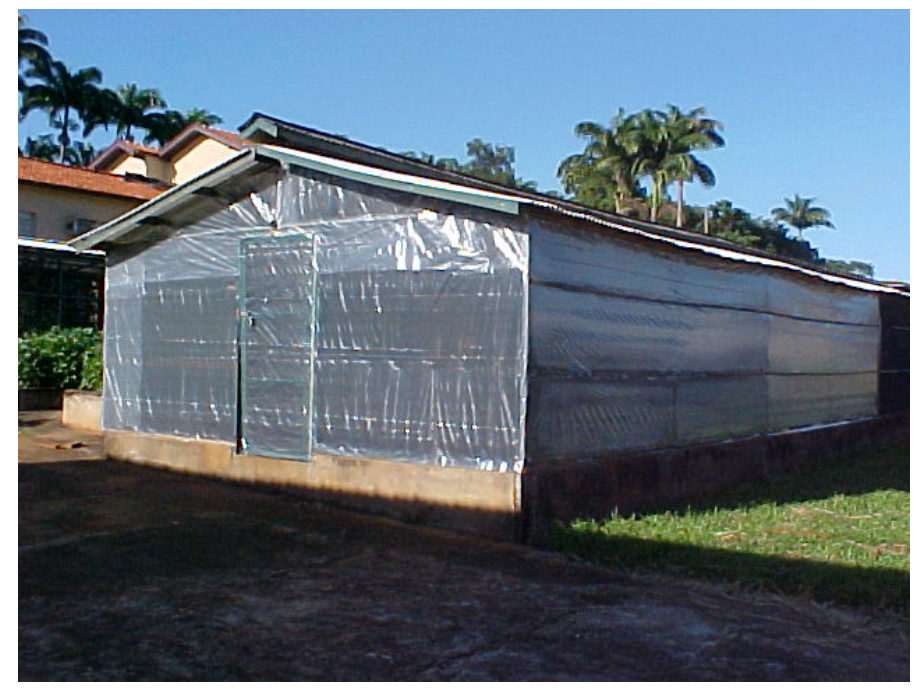

Figura 4 - Vista geral do telado de inoculação, com as laterais cobertas com plástico em toda sua superfície
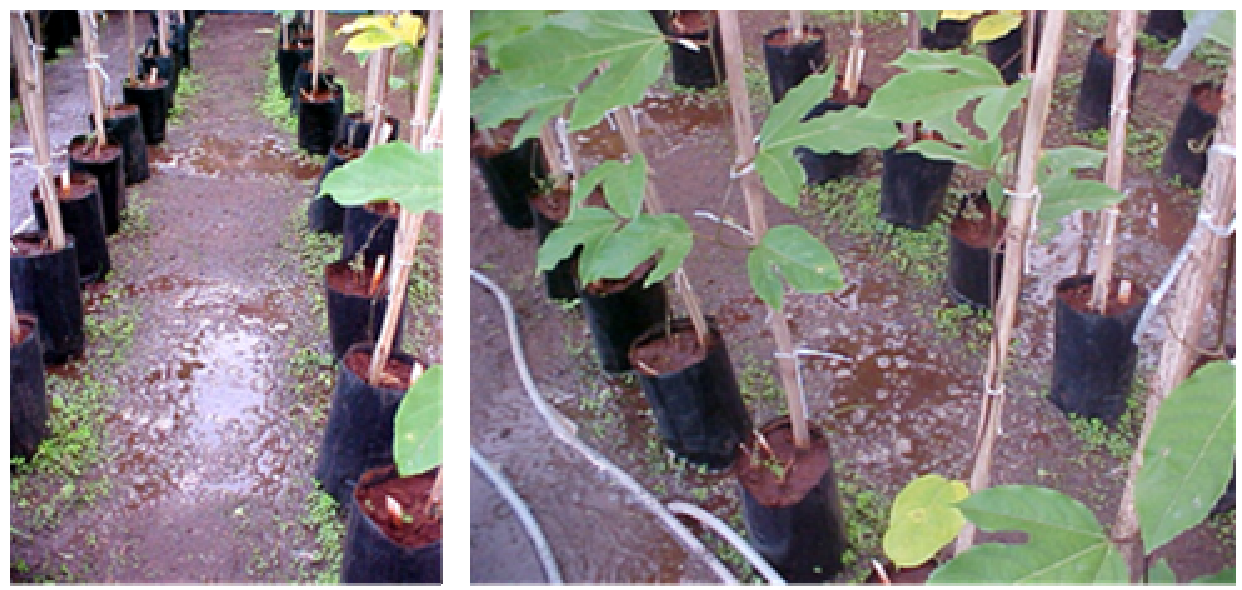

Figura 5 - Irrigação do piso de terra batida, realizada manualmente, para a criação de um ambiente úmido no interior do telado de inoculação

Os indivíduos da população segregante foram inoculados seguindo o procedimento adotado por Lopes (2003) no qual folhas completamente desenvolvidas 
foram inoculadas pelo método de corte dos bordos. Foram efetuados cortes de $3 \mathrm{~cm}$ no lóbulo central de três folhas por planta, usando tesoura mergulhada em suspensão bacteriana, padronizada em espectrofotômetro (comprimento de onda de $600 \mathrm{~nm}$ e densidade óptica de 0,3) (Figura 6).
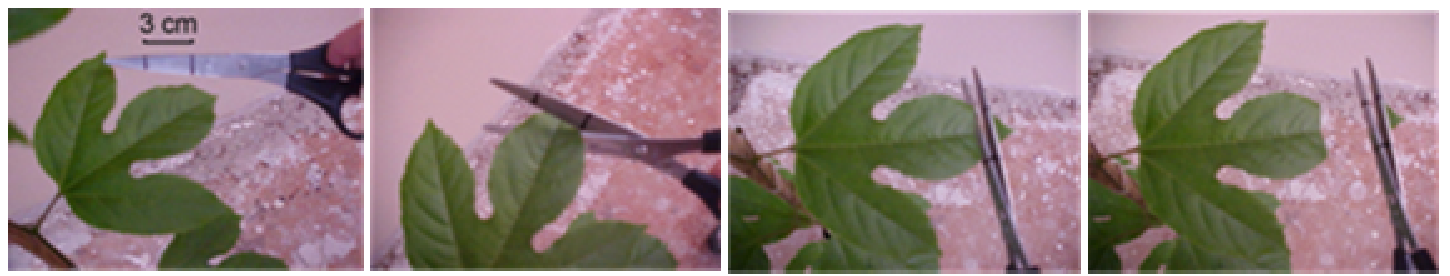

Figura 6 - Seqüência da metodologia adotada para inoculação, usando tesoura mergulhada em suspensão bacteriana

Devido à própria variabilidade genética, os indivíduos apresentaram diferenças de crescimento vegetativo e, conseqüentemente, caso fossem escolhidas folhas situadas em uma determinada altura a partir do solo, as mesmas teriam diferenças de idade entre os genótipos (indivíduos).

Como o ápice da planta apresenta contínuo crescimento e formação de folhas novas, este foi, realmente, o ponto de partida para a escolha das folhas a serem inoculadas. Tendo a folha mais nova atingido seu completo desenvolvimento, esta se tornava apta a ser inoculada. Tomou-se o cuidado em se avaliar as folhas que possuíssem a mesma idade entre os genótipos e também mesmo tamanho dentro de cada parcela. A última folha a ser inoculada, de cada genótipo, foi a sexta folha contada a partir do ápice para a base da planta, já completamente desenvolvida, sendo, portanto, a folha mais nova a ser inoculada. A folha mais velha foi denominada como folha 1 e a mais nova como folha 3 (Figura 7). 


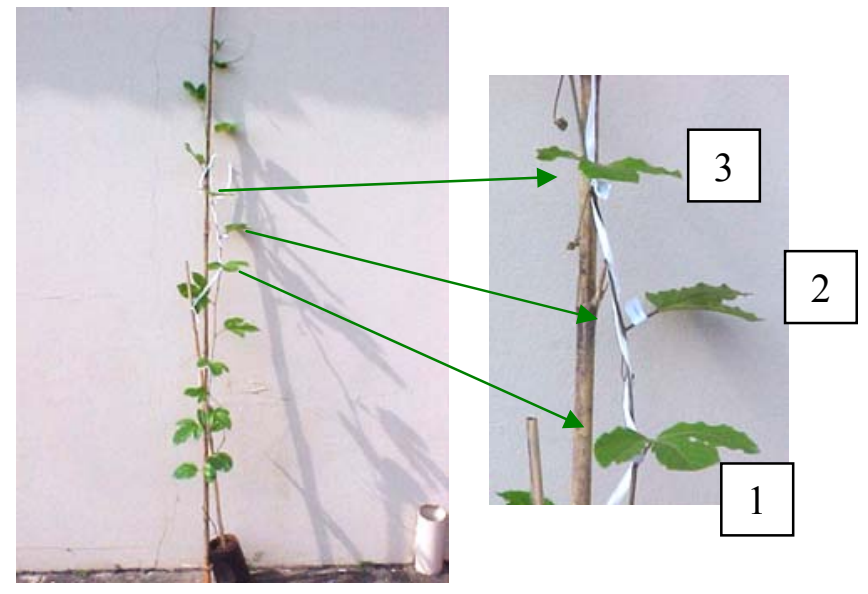

67

Figura 7 - Determinação das folhas para proceder a inoculação: os números indicam a posição das folhas na muda

Foram utilizadas em todos os genótipos folhas que possuíam a mesma idade, considerando cada posição. Entretanto, o crescimento diferenciado fez com que a altura de inoculação entre os genótipos ficasse diferente. Por exemplo, considerando a média das três repetições, para cada genótipo, a altura da folha número 2 variou entre 0,5 e 1,5 m.

\subsubsection{Segundo experimento}

Para o segundo experimento, as plantas do experimento anterior foram reaproveitadas. Duas semanas após a retirada das folhas inoculadas, foi realizado teste de exsudação das plantas (Figura 8), sendo confirmado a ação sistêmica da bacteriose em todos os genótipos. Entretanto, não foi possível discriminar se havia diferenças entre os genótipos, ou seja, se um genótipo possuía maior exsudação bacteriana que os demais. 


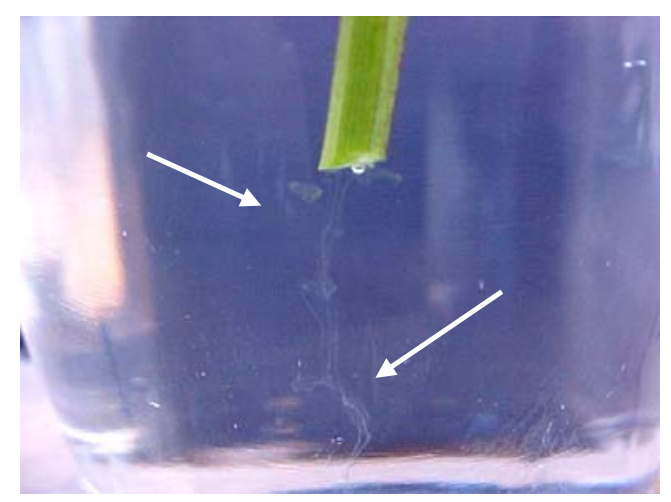

Figura 8 - Teste de exsudação bacteriana (setas) realizado após o primeiro experimento, no qual foi usado o isolado " $18 \mathrm{~b}$ "

Como não foi verificado o desenvolvimento da moléstia nas plantas, após dois dias da retirada das folhas inoculadas, foram realizadas novas adubações e, em dias alternados, novos tratamentos com Benlate ${ }^{\circledR} 500$ e Azodrin 400. Para inoculação, neste segundo experimento, foi utilizada uma mistura em igual volume e concentração de ambos isolados bacterianos.

\subsubsection{Avaliação de metodologias para medição de lesões foliares em maracujá- amarelo}

Durante a avaliação da severidade das lesões, as mensurações foram realizadas com três metodologias, comparando-se sua precisão, confiabilidade e praticidade. A idéia central foi identificar qual seria o melhor método a ser utilizado nas análises de identificação e localização de QRL.

No $17^{\circ}$ dia após a inoculação, as folhas inoculadas tiveram sua última área demarcada, pois em alguns genótipos a lesão havia chegado ao pecíolo e não havia como realizar uma próxima mensuração (Figura 9). 

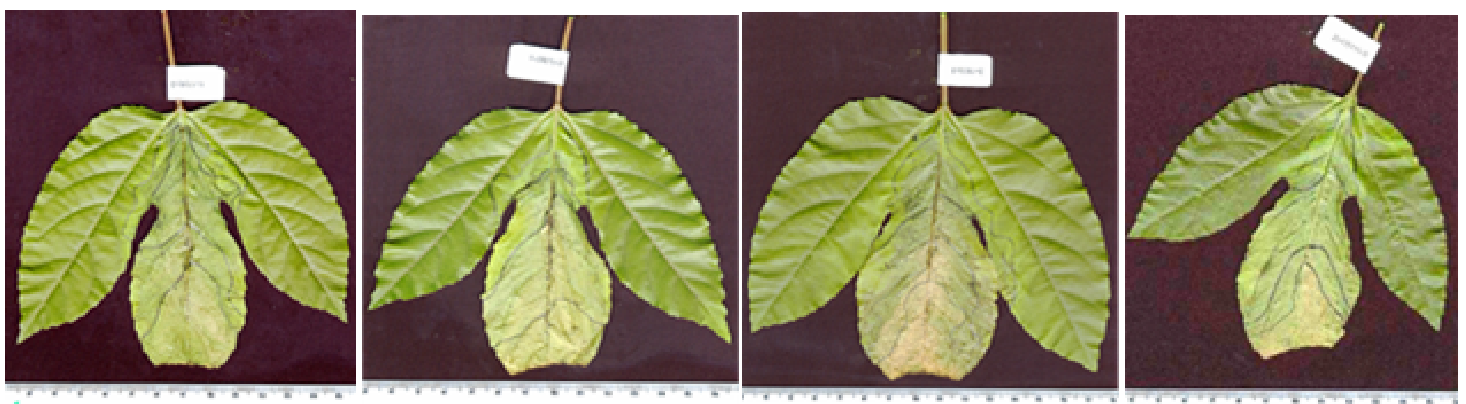

Figura 9 - Aspecto das folhas indicando o desenvolvimento da clorose até o pecíolo

No dia seguinte, as folhas inoculadas foram destacadas das plantas e submetidas à avaliação pelas seguintes metodologias:

a) A área da última lesão, a mais externa, foi desenhada em plástico transparente para depois se obter uma cópia em papel. As lesões foram então recortadas e medidas através de um medidor de área foliar Li-cor (Li-3100, Nebraska, EUA) de acordo com Nakatani (2001) e Lopes (2003) (Figura 10).
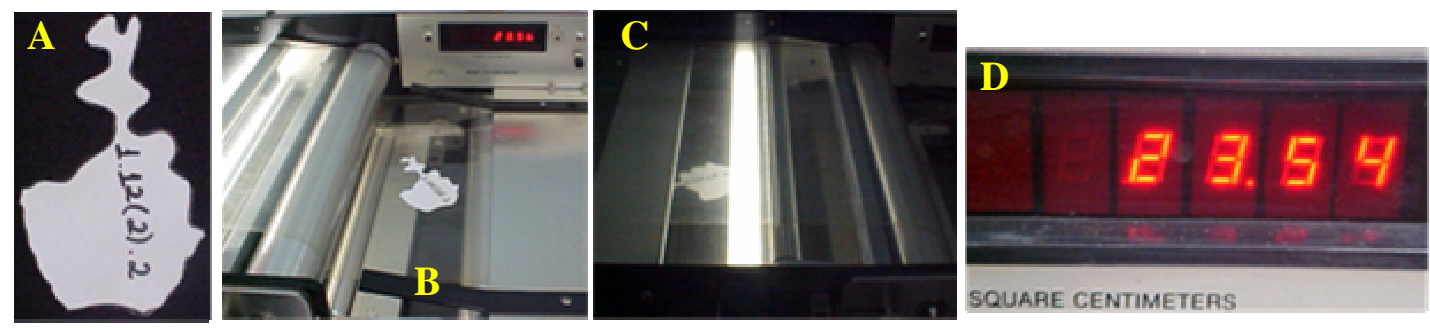

Figura 10 - A) Exemplo de um recorte da cópia do desenho de uma lesão desenhada em papel; B) Entrada do recorte na esteira da máquina; C) Recorte passando pela lâmpada; D) Resultado da área, em $\mathrm{cm}^{2}$, no painel da máquina

Esse recorte foi inserido na máquina Li-cor por três vezes, obtendo-se uma média para redução de possíveis erros na mensuração. Essa máquina trabalha com a medição da área pela projeção de sua sombra produzida quando o recorte passa por uma lâmpada, levado por uma esteira transparente, e que é captada por uma câmera. O resultado é liberado por em um painel $\left(\mathrm{em}^{2} \mathrm{~cm}^{2}\right.$. 
Esse método é bastante utilizado (Díaz et al., 2001; Jadão et al., 2004; Martins et al., 2004), pois apresenta resultados de forma rápida e com boa confiança. Este é um método menos subjetivo, comparando-se com o método visual. Entretanto, tal como foi utilizado por Nakatani (2001) e Lopes (2003), podem aparecer alguns erros, pois ao fazer a cópia em xerox, as imagens saem um pouco distorcidas, como demonstram as Figuras 17A e 17B.

b) Uso de uma escala diagramática (Figura 11), tal como proposto por Miranda (2004) e, por avaliação visual, foi obtida a porcentagem de área lesionada por folha.

Por envolver muita subjetividade, o valor fenotípico, para cada genótipo, foi obtido a partir do valor médio, calculado a partir de mensurações obtidas por quatro pessoas diferentes.
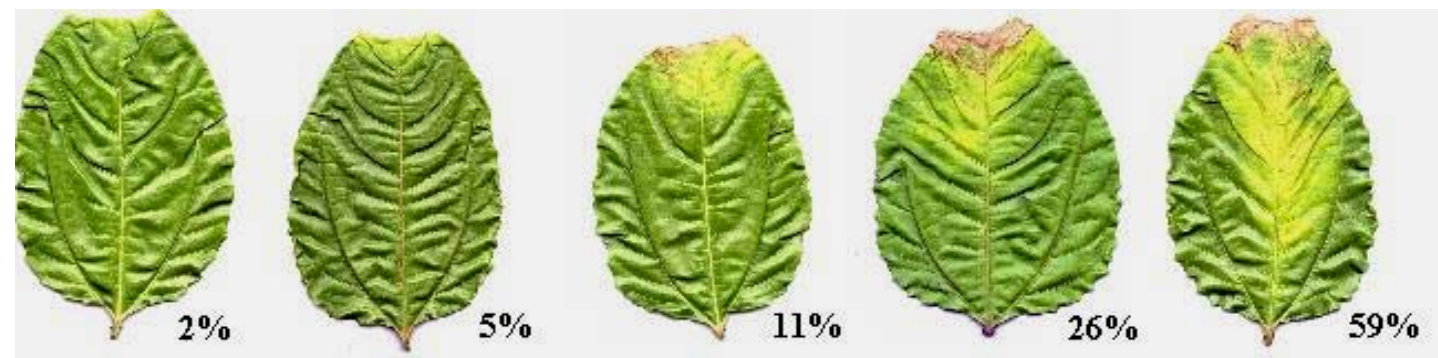

Figura 11 - Escala diagramática adotada para análise visual, proposta por Miranda (2004)

c) Uso do programa computacional QUANT (Liberato, 2004), o qual foi desenvolvido para quantificar a severidade de sintomas de doenças de plantas, a partir de imagens digitalizadas obtidas por meio de um "scanner" ou máquinas fotográficas digitais. Dessa forma, foram analisadas as imagens das folhas inoculadas, digitalizadas com o auxílio de um "scanner" (Figura 12). 

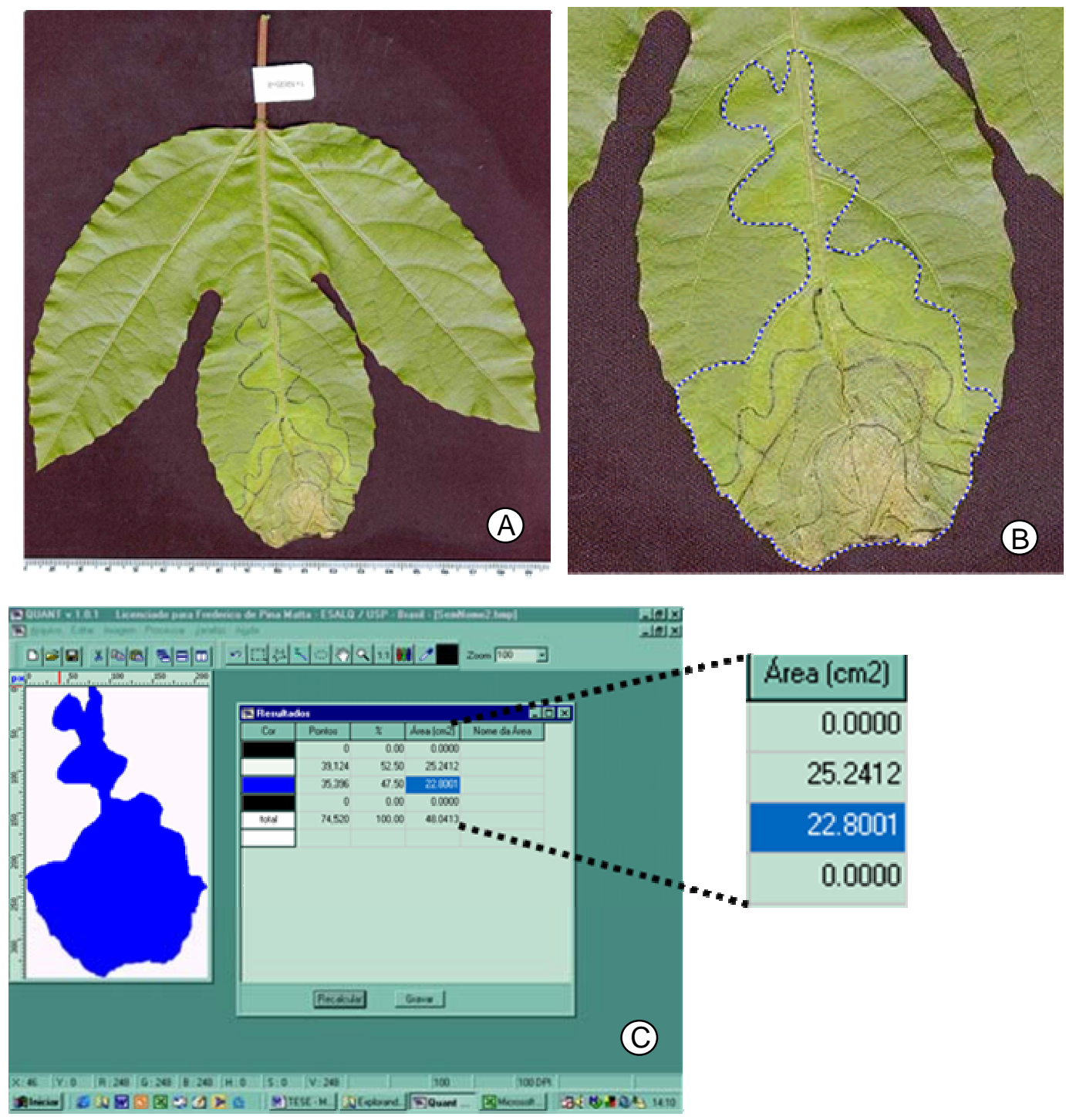

Figura 12 - A) Imagem digitalizada de uma folha inoculada; B) Uso do programa computacional QUANT para obtenção da área lesionada, através da demarcação da lesão de interesse; C) Resultado, destacado em azul, mostrando que a lesão tem $22,80 \mathrm{~cm}^{2}$

O delineamento estatístico utilizado para a avaliação das metodologias foi o de blocos completos casualizados, com parcelas sub-subdivididas, em três repetições, totalizando 318 plantas mantidas em telado. Cada parcela foi composta por uma planta, tutorada verticalmente. A primeira divisão, em sub-parcelas, foi com base no efeito do 
posicionamento da folha, sendo analisada a quarta área demarcada de três folhas definitivas. A segunda divisão, em sub-subparcelas, foi base nas três metodologias de avaliação. Vale salientar que a idade das folhas, em cada posição, foi considerada igual para todos os genótipos. As mudas foram dispostas com $15 \mathrm{~cm}$ entre plantas e $40 \mathrm{~cm}$ entre linhas (Figura 13).
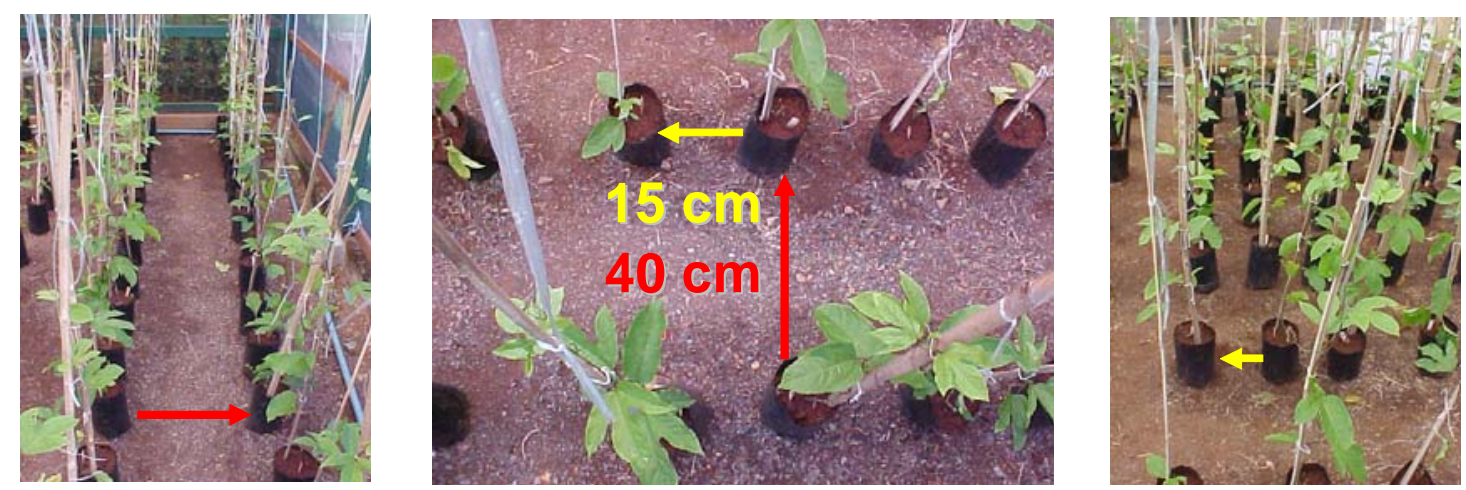

Figura 13 - Disposição das plantas no telado de inoculação, em fase inicial de desenvolvimento vegetativo

As mensurações das lesões obtidas em $\mathrm{cm}^{2}$ (QUANT e Li-cor) foram transformadas para porcentagem através da utilização das áreas das folhas. Para tanto, foram obtidas as áreas foliares com o auxílio do programa computacional QUANT.

\subsubsection{Análise do desenvolvimento da bacteriose em maracujá-amarelo}

A metodologia utilizada para a análise do desenvolvimento da doença foi a do programa computacional QUANT (Liberato, 2004), por possibilitar uma mensuração mais fiel à área de lesão, conforme será demonstrado pelos resultados a serem apresentados e discutidos posteriormente.

No primeiro experimento, a avaliação da severidade da doença foi realizada aos $11,13,15$ e 17 dias após a inoculação e no segundo, somente aos 13, 15 e 17 dias. Para 
determinar a evolução das lesões entre esses períodos, foi demarcada, em cada folha, uma curva delimitando o avanço de cada lesão no período correspondente, com o auxílio de uma caneta de retroprojetor, de tinta preta, com ponta fina e macia. Assim, ao final do primeiro e do segundo experimentos, cada planta possuía as três folhas demarcadas com quatro e três curvas, respectivamente (Figuras 14 e 15).
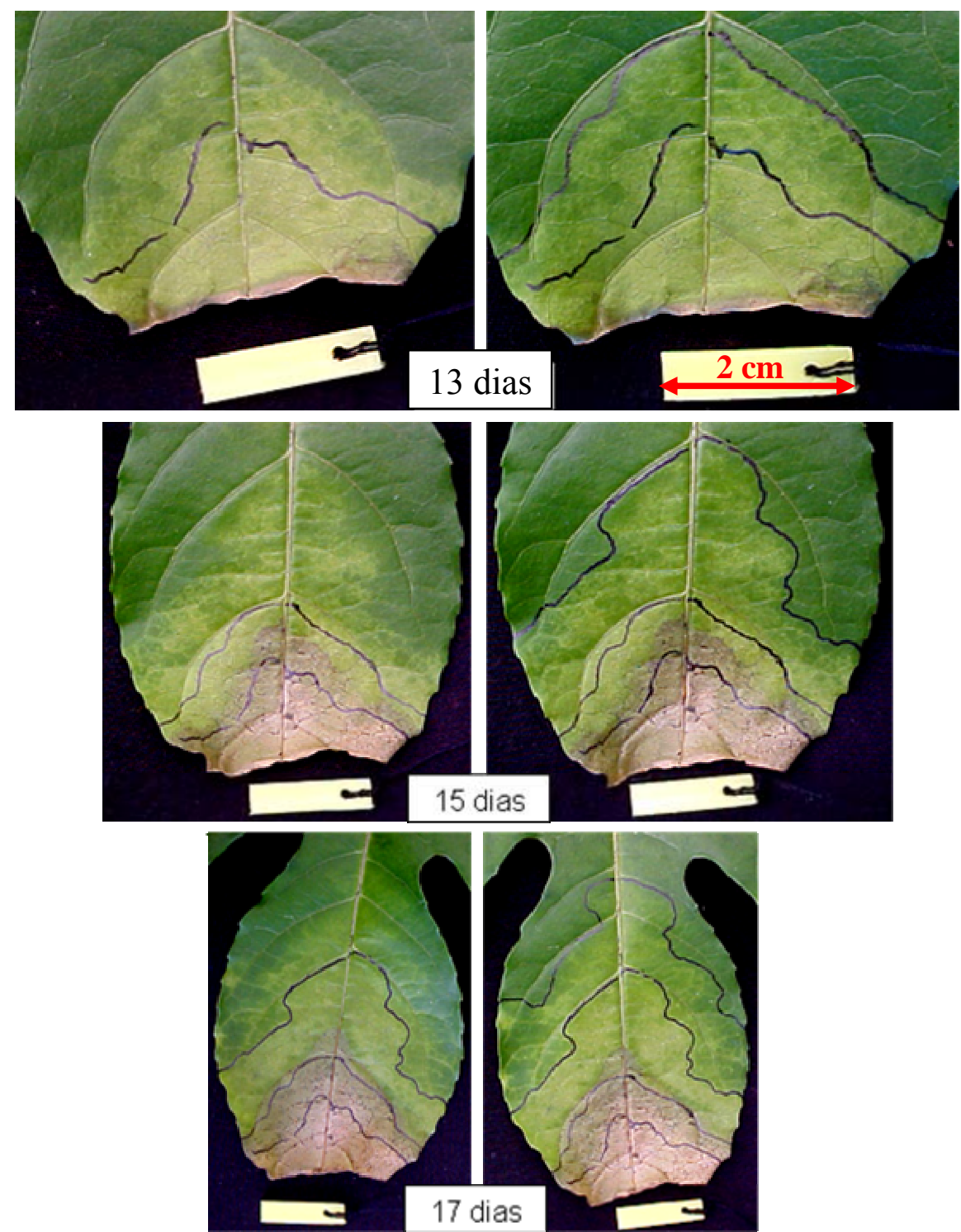

Figura 14 - Primeiro experimento. Exemplo da demarcação do avanço da bacteriose aos 13, 15 e 17 dias após a inoculação do genótipo 17(35), folha 2 da terceira repetição. $\mathrm{O}$ objeto amarelo possui $2 \mathrm{~cm}$ de largura 

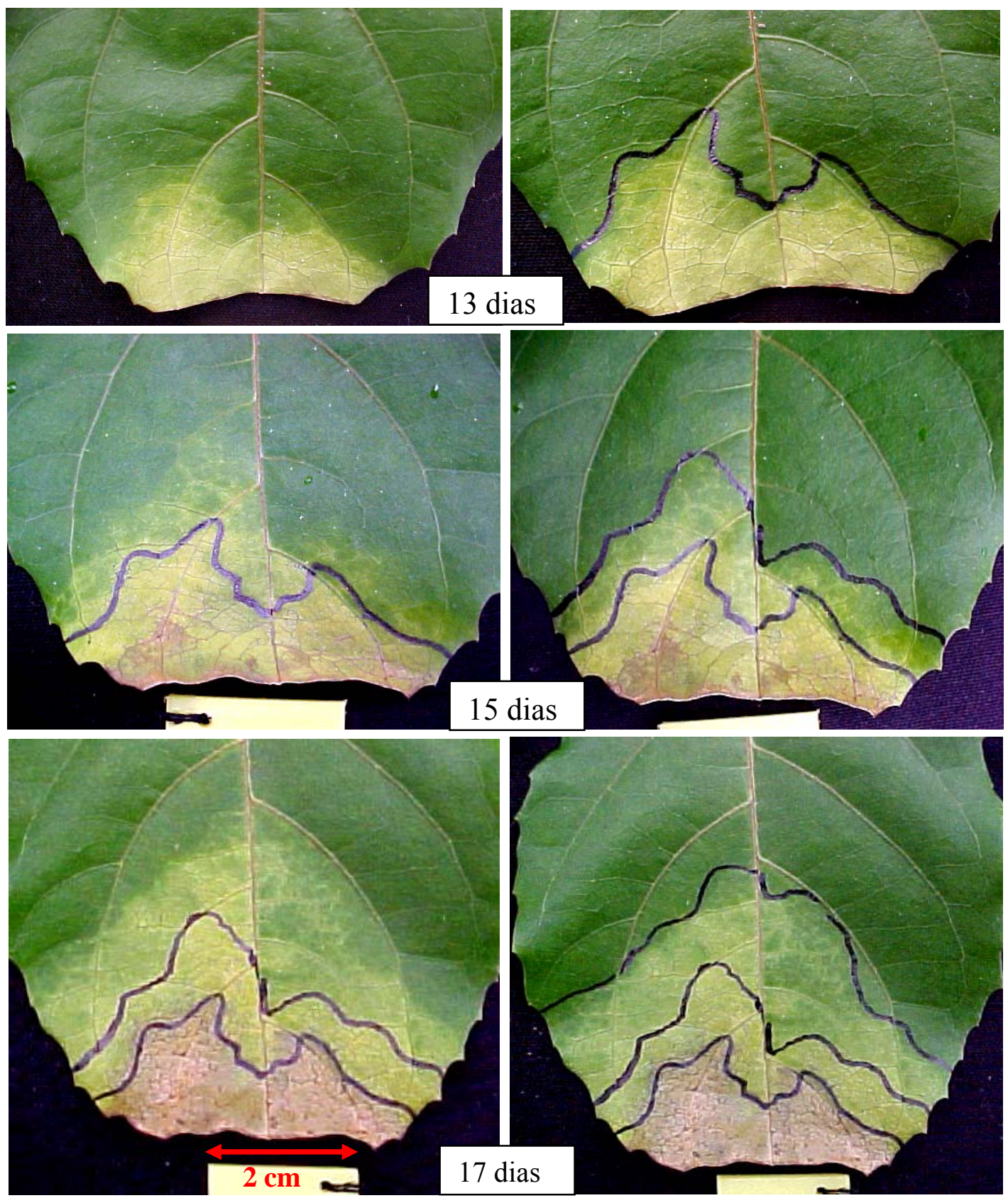

Figura 15 - Segundo experimento. Exemplo da demarcação do avanço da bacteriose aos 13, 15 e 17 dias após a inoculação do genótipo 11(1), folha 1 da primeira repetição

O delineamento utilizado para o estudo do desenvolvimento da bacteriose também foi o de blocos completos casualizados, com parcelas sub-subdivididas, em três 
repetições, sendo cada parcela composta por uma planta; para cada sub-parcela foi avaliado o efeito do posicionamento da folha e, em cada folha, para as sub-subparcelas foi considerada a evolução das lesões mensuradas nas diferentes oportunidades.

Quanto à unidade de avaliação poderiam ser utilizadas tanto as porcentagens das folhas lesionadas quanto as áreas, em $\mathrm{cm}^{2}$, limitadas pelos contornos das lesões. Entretanto, optou-se pela utilização das áreas, devido à existência de diferenças de tamanho das folhas entre os genótipos, já observadas durante a formação das mudas. Como a inoculação foi realizada com base em um corte de $3 \mathrm{~cm}$, nas três folhas, a área foliar lesionada pôde ser comparada, sendo as diferenças de tamanho apresentadas entre os genótipos explicadas pela dificuldade de colonização dos indivíduos mais resistentes, comparativamente aos mais susceptíveis.

\subsubsection{Análises estatísticas}

A análise de variância para a avaliação das metodologias utilizadas para medição de lesões foliares foi realizada segundo o modelo:

$Y_{i j k l}=\mu+g_{i}+b_{j}+g b_{i j}+f_{k}+g f_{i k}+b f_{j k}+b g f_{i j k}+m_{l}+g m_{i l}+f m_{k l}+g f m_{i k l}+e_{i j k l}$, sendo:

$Y_{i j k l}$ o valor fenotípico do i-ésimo indivíduo na repetição $\mathrm{j}$, na folha $\mathrm{k}$ e com a metodologia 1;

$\mu$ a média geral do experimento;

$g_{i}$ o efeito do genótipo i;

$b_{j}$ o efeito do bloco $\mathrm{j}$;

$g b_{i j}$ o efeito da interação entre genótipo e bloco; 
$f_{k}$ o efeito da posição da folha inoculada;

$g f_{i k}$ o efeito da interação entre genótipo e a posição da folha lesionada;

$b f_{j k}$ o efeito da interação entre blocos e a posição da folha lesionada;

$b f_{i j k}$ o efeito da interação entre blocos, genótipo e a posição da folha lesionada;

$m_{l}$ o efeito da metodologia utilizada para mensuração das lesões;

$g m_{i l}$ o efeito da interação entre genótipo e metodologia utilizada para mensuração das lesões;

$f m_{k l}$ o efeito da interação entre posição da folha lesionada e metodologia utilizada para mensuração das lesões;

$g f_{i k l}$ o efeito da interação entre genótipo, posição da folha inoculada e a metodologia utilizada para mensuração das lesões;

$e_{i j k l}$ o erro aleatório associado a observação $\mathrm{Y}_{\mathrm{ijkl}}$.

Nessa análise o interesse foi inferir acerca das três metodologias utilizadas. Os efeitos de posição das folhas e das metodologias foram considerados como fixos e os efeitos de blocos e genótipos foram considerados aleatórios. As premissas associadas a esse modelo são:

(i) $\mathrm{G}_{\mathrm{i}} \sim \mathrm{N}\left(0, \sigma_{\mathrm{g}}^{2}\right)$, independentes;

(ii) $\mathrm{B}_{\mathrm{j}} \sim \mathrm{N}\left(0, \sigma_{\mathrm{b}}^{2}\right)$, independentes;

(iii) $\mathrm{GB}_{\mathrm{ij}} \sim \mathrm{N}\left(0, \sigma_{\mathrm{gb}}^{2}\right)$, independentes;

(iv) $\mathrm{F}_{\mathrm{k}}$, fixo, $\therefore \mathrm{E}\left(\mathrm{f}_{\mathrm{k}}\right)=\mathrm{f}_{\mathrm{k}}, \mathrm{E}\left(\mathrm{f}_{\mathrm{k}}^{2}\right)=\mathrm{f}_{\mathrm{k}}^{2} \mathrm{e} \sum_{\mathrm{k}} \mathrm{f}_{\mathrm{k}}=0$; 
(v) $\mathrm{GF}_{\mathrm{ik}} \sim \mathrm{N}\left(0, \sigma_{\mathrm{gf}}^{2}\right)$, independentes;

(vi) $\mathrm{BF}_{\mathrm{jk}} \sim \mathrm{N}\left(0, \sigma_{\mathrm{bf}}^{2}\right)$, independentes;

(vii) $\mathrm{BGF}_{\mathrm{ijk}} \sim \mathrm{N}\left(0, \sigma_{\mathrm{bgf}}^{2}\right)$, independentes;

(viii) $M_{l}$, fixo, $\therefore E\left(m_{l}\right)=m_{l}, E\left(m_{l}^{2}\right)=m_{l}^{2} \mathrm{e} \sum_{l} m_{l}=0$;

(ix) $G M_{i l} \sim \mathrm{N}\left(0, \sigma_{g m}^{2}\right)$, independentes;

(x) $F M_{k l}$, fixo, $\therefore E\left(f m_{k l}\right)=f m_{k l}, E\left(f m_{k l}^{2}\right)=f m_{k l}^{2}$ e $\sum_{k} f m_{k l}=\sum_{l} f m_{k l}=\sum_{k l} f m_{k l}=0$;

(xi) $G F M_{i k l} \sim \mathrm{N}\left(0, \sigma_{g f m}^{2}\right)$, independentes;

(xii) $\mathrm{e}_{\mathrm{ijkl}} \sim\left(0, \sigma^{2}\right)$, independentes; $\mathrm{e}$

(xiii) $\mathrm{G}_{\mathrm{i}}, \mathrm{B}_{\mathrm{j}}, \mathrm{GB}_{\mathrm{ij}}, \mathrm{GF}_{\mathrm{ik}}, \mathrm{BF}_{\mathrm{jk}}, \mathrm{BGF}_{\mathrm{jik}}, G M_{i l}, G F M_{i k l}$ e $\mathrm{e}_{\mathrm{ijkl}}$ são efeitos aleatórios independentes, para todo $\mathrm{i}, \mathrm{j}, \mathrm{k}$ e $\mathrm{l}$.

$\mathrm{Na}$ análise de variância, para avaliação do desenvolvimento da bacteriose, o interesse foi inferir acerca da população segregante. Da mesma forma, os efeitos de blocos e genótipos foram considerados aleatórios. Os efeitos de posição das folhas e das áreas, mensuradas a cada dois dias, foram considerados como fixos. Essa análise foi realizada segundo o modelo:

$\mathrm{Y}_{\mathrm{ijkl}}=\mu+\mathrm{g}_{\mathrm{i}}+\mathrm{b}_{\mathrm{j}}+\mathrm{gb}_{\mathrm{ij}}+\mathrm{f}_{\mathrm{k}}+\mathrm{gf}_{\mathrm{ik}}+\mathrm{bf}_{\mathrm{jk}}+\mathrm{bgf}_{\mathrm{ijk}}+\mathrm{a}_{1}+\mathrm{ga}_{\mathrm{il}}+\mathrm{fa}_{\mathrm{kl}}+\mathrm{gfa}_{\mathrm{ikl}}+\mathrm{e}_{\mathrm{ijkl}}$,

sendo:

$Y_{i j k l}$ o valor fenotípico do i-ésimo indivíduo na repetição j, na folha k e com a área l;

$\mu$ a média geral do experimento; 
$g_{i}$ o efeito do genótipo i;

$b_{j}$ o efeito do bloco $\mathrm{j}$;

$g b_{i j}$ o efeito da interação entre genótipo e bloco;

$f_{k}$ o efeito da posição da folha inoculada;

$g f_{i k}$ o efeito da interação entre genótipo e a posição da folha inoculada;

$b f_{j k}$ o efeito da interação entre blocos e a posição da folha inoculada;

$b g f_{i j k}$ o efeito da interação entre blocos, genótipo e a posição da folha inoculada;

$a_{l}$ o efeito da data de mensuração, obtida pelas áreas das lesões, mensuradas a cada dois dias;

$g a_{i l}$ o efeito da interação entre genótipo e data de mensuração das lesões;

$f a_{k l}$ o efeito da interação entre posição da folha inoculada e data de mensuração das lesões;

$g f a_{i k l}$ o efeito da interação entre genótipo, posição da folha inoculada e a data de mensuração das lesões;

$e_{i j k l}$ o erro aleatório associado a observação $\mathrm{Y}_{\mathrm{ijkl}}$.

Da mesma forma, as premissas normalmente associadas a esse modelo considerado são:

(i) $\mathrm{G}_{\mathrm{i}} \sim \mathrm{N}\left(0, \sigma_{\mathrm{g}}^{2}\right)$, independentes;

(ii) $\mathrm{B}_{\mathrm{j}} \sim \mathrm{N}\left(0, \sigma_{\mathrm{b}}^{2}\right)$, independentes; 
(iii) $\mathrm{GB}_{\mathrm{ij}} \sim \mathrm{N}\left(0, \sigma_{\mathrm{gb}}^{2}\right)$, independentes;

(iv) $\mathrm{F}_{\mathrm{k}}$, fixo, $\therefore \mathrm{E}\left(\mathrm{f}_{\mathrm{k}}\right)=\mathrm{f}_{\mathrm{k}}, \mathrm{E}\left(\mathrm{f}_{\mathrm{k}}^{2}\right)=\mathrm{f}_{\mathrm{k}}^{2} \mathrm{e} \sum_{\mathrm{k}} \mathrm{f}_{\mathrm{k}}=0$;

(v) $\mathrm{GF}_{\mathrm{ik}} \sim \mathrm{N}\left(0, \sigma_{\mathrm{gf}}^{2}\right)$, independentes;

(vi) $\mathrm{BF}_{\mathrm{jk}} \sim \mathrm{N}\left(0, \sigma_{\mathrm{bf}}^{2}\right)$, independentes;

(vii) $\mathrm{BGF}_{\mathrm{ijk}} \sim \mathrm{N}\left(0, \sigma_{\mathrm{bgf}}^{2}\right)$, independentes;

(viii) $\mathrm{A}_{1}$, fixo, $\therefore \mathrm{E}\left(\mathrm{a}_{1}\right)=\mathrm{a}_{1}, \mathrm{E}\left(\mathrm{a}_{1}^{2}\right)=\mathrm{a}_{1}^{2} \mathrm{e} \sum_{1} \mathrm{a}_{1}=0$;

(ix) $\mathrm{GA}_{\mathrm{il}} \sim \mathrm{N}\left(0, \sigma_{\mathrm{ga}}^{2}\right)$, independentes;

(x) $\mathrm{FA}_{\mathrm{kl}}$, fixo, $\therefore \mathrm{E}\left(\mathrm{fa}_{\mathrm{kl}}\right)=\mathrm{fa}_{\mathrm{kl}}, \mathrm{E}\left(\mathrm{fa}_{\mathrm{kl}}^{2}\right)=\mathrm{fa}_{\mathrm{kl}}^{2} \mathrm{e} \sum_{\mathrm{k}} \mathrm{fa}_{\mathrm{kl}}=\sum_{\mathrm{l}} \mathrm{fa}_{\mathrm{kl}}=\sum_{\mathrm{kl}} \mathrm{fa}_{\mathrm{kl}}=0$;

(xi) $\mathrm{GFA}_{\mathrm{ikl}} \sim \mathrm{N}\left(0, \sigma_{\mathrm{gfa}}^{2}\right)$, independentes;

(xii) $\mathrm{e}_{\mathrm{ijkl}} \sim\left(0, \sigma^{2}\right)$, independentes; $\mathrm{e}$

(xiii) $\mathrm{G}_{\mathrm{i}}, \mathrm{B}_{\mathrm{j}}, \mathrm{GB}_{\mathrm{ij}}, \mathrm{GF}_{\mathrm{ik}}, \mathrm{BF}_{\mathrm{jk}}, \mathrm{BGF}_{\mathrm{jik}}, \mathrm{GA}_{\mathrm{il}}, \mathrm{GFA}_{\mathrm{ikl}}$ e $\mathrm{e}_{\mathrm{ijkl}}$ são efeitos aleatórios independentes, para todo $\mathrm{i}, \mathrm{j}, \mathrm{k}$ e $\mathrm{l}$.

As análises de variâncias, seguindo os modelos estatísticos apresentados, foram realizadas utilizando o programa estatístico SAS - Statistical Analysis System (SAS Institute Inc., 1990). Alguns cálculos adicionais foram necessários, pois todos os testes $\mathrm{F}$ foram realizados com um mesmo resíduo, ou seja, o resíduo do modelo. Somente os testes $\mathrm{F}$ apresentados pelas fontes de variação contidas em nível de sub-subparcela estavam corretos, sendo necessário, portanto, identificar os verdadeiros testadores referentes às demais fontes de variação do modelo.

Como os dois modelos possuem a mesma estrutura, será apresentado um mesmo esquema para as análises de variâncias. $\mathrm{O}$ esquema recebeu a seguinte codificação: 1) O 
fator efeito de genótipo passa a ser denominado como fator $\mathrm{G}$; 2) O fator efeito da posição das folhas passa a ser denominado como fator $\mathrm{P}$; 3) Tanto os fatores efeito da data de mensuração (área) quanto o efeito das metodologias utilizadas passam a ser considerados, em sua respectiva análise, como Fator $C$.

O esquema para as análises de variâncias considerando os modelos apresentados encontra-se no Quadro 1 (Steel et al., 1997). As esperanças dos quadrados médios $\mathrm{E}(\mathrm{QM})$ foram obtidas pelo método prático proposto por Hicks (1973).

Quadro 1. Esquema das análises de variâncias para estudo das metodologias e do desenvolvimento da bacteriose, utilizando delineamento em blocos casualizados com parcelas sub-subdivididas, indicando os graus de liberdade, quadrados médios (QM) e suas respectivas esperanças E(QM)

\begin{tabular}{|c|c|c|c|}
\hline Fonte de Variação & Graus de liberdade & $\mathrm{QM}$ & $\mathrm{E}(\mathrm{QM})^{1}$ \\
\hline Blocos & $\mathrm{J}-1$ & $Q M_{b}$ & $\sigma^{2}+L \sigma_{g b p}^{2}+I L \sigma_{b p}^{2}+K L \sigma_{g b}^{2}+I K L \sigma_{b}^{2}$ \\
\hline Fator G & $\mathrm{I}-1$ & $Q M_{g}$ & $\sigma^{2}+J \sigma_{g p c}^{2}+J K \sigma_{g c}^{2}+L \sigma_{g b p}^{2}+J L \sigma_{g p}^{2}+K L \sigma_{g b}^{2}+J K L \sigma_{g}^{2}$ \\
\hline Blocos x Fator G & $(\mathrm{I}-1)(\mathrm{J}-1)$ & $Q M_{b g}$ & $\sigma^{2}+\mathrm{L} \sigma_{\mathrm{gbp}}^{2}+\mathrm{KL} \sigma_{\mathrm{gb}}^{2}$ \\
\hline Parcelas & $(\mathrm{IJ}-1)$ & & \\
\hline Fator P & $(\mathrm{K}-1)$ & $Q M_{p}$ & $\sigma^{2}+J \sigma_{g p c}^{2}+L \sigma_{g b p}^{2}+I L \sigma_{b p}^{2}+J L \sigma_{g p}^{2}+I J L \Phi_{p}$ \\
\hline Fator G x Fator $\mathrm{P}$ & $(\mathrm{I}-1)(\mathrm{K}-1)$ & $Q M_{g p}$ & $\sigma^{2}+J \sigma_{g p c}^{2}+L \sigma_{g b p}^{2}+J L \sigma_{g p}^{2}$ \\
\hline Blocos $\mathrm{x}$ Fator $\mathrm{P}$ & $(\mathrm{J}-1)(\mathrm{K}-1)$ & $Q M_{b p}$ & $\sigma^{2}+\mathrm{L} \sigma_{\mathrm{gbp}}^{2}+\mathrm{IL} \sigma_{\mathrm{bp}}^{2}$ \\
\hline $\begin{array}{l}\text { Blocos } \mathrm{x} \text { Fator } \mathrm{G} x \\
\text { Fator } \mathrm{P}\end{array}$ & $(\mathrm{J}-1)(\mathrm{I}-1)(\mathrm{K}-1)$ & $Q M_{b g p}$ & $\sigma^{2}+\mathrm{L} \sigma_{\mathrm{gbp}}^{2}$ \\
\hline Subparcelas & IJK -1 & & \\
\hline Fator $C$ & $\mathrm{~L}-1$ & $Q M_{c}$ & $\sigma^{2}+J \sigma_{g p c}^{2}+J K \sigma_{g c}^{2}+I J K \Phi_{c}$ \\
\hline Fator $\mathrm{G} \times$ Fator $C$ & $(\mathrm{I}-1)(\mathrm{L}-1)$ & $Q M_{g c}$ & $\sigma^{2}+J \sigma_{g p c}^{2}+J K \sigma_{g c}^{2}$ \\
\hline Fator $\mathrm{P} \times$ Fator $\mathrm{C}$ & $(\mathrm{K}-1)(\mathrm{L}-1)$ & $Q M_{p c}$ & $\sigma^{2}+J \sigma_{g p c}^{2}+I J \Phi_{p c}$ \\
\hline $\begin{array}{l}\text { Fator } \mathrm{G} \times \text { Fator } \mathrm{P} x \\
\quad \text { Fator C }\end{array}$ & $(\mathrm{I}-1)(\mathrm{K}-1)(\mathrm{L}-1)$ & $Q M_{g p c}$ & $\sigma^{2}+J \sigma_{g p c}^{2}$ \\
\hline Resíduo & $\operatorname{IK}(\mathrm{L}-1)(\mathrm{J}-1)$ & $Q M_{\text {resíduo }}$ & $\sigma^{2}$ \\
\hline Total & IJKL -1 & & \\
\hline
\end{tabular}


De acordo com as esperanças dos quadrados médios, os testes $\mathrm{F}$ realizados a partir desse modelo são:

- Teste F para o fator genótipo: $\frac{Q M_{g}+Q M_{b g p}+Q M_{g p c}}{Q M_{g p}+Q M_{g c}+Q M_{b g}}$, com $\mathrm{n}_{1}$ e $\mathrm{n}_{2}$ graus de liberdade;

- Para o fator posição das folhas: $\frac{\mathrm{QM}_{\mathrm{p}}+\mathrm{QM}_{\mathrm{bgp}}}{\mathrm{QM}_{\mathrm{gp}}+\mathrm{QM}_{\mathrm{bp}}}, \operatorname{com} \mathrm{n}_{3}$ e $\mathrm{n}_{4}$ graus de liberdade;

- Para o Fator C: $\frac{Q M_{c}}{Q M_{g c}}$ com os respectivos graus de liberdade;

- Para o fator interação genótipo x posição: $\frac{Q M_{g p}+Q M_{\text {resíduo }}}{Q M_{b g p}+Q M_{g p c}}$ com $\mathrm{n}_{5}$ e $\mathrm{n}_{6}$ graus de liberdade;

- Para o fator interação genótipo x Fator $C: \frac{Q M_{g c}}{Q M_{g p c}}$ com os respectivos graus de liberdade;

- Para o fator interação posição x Fator $C: \frac{Q M_{p c}}{Q M_{g p c}}$ com os respectivos graus de liberdade;

- Para o fator interação genótipo x posição x Fator $C: \frac{Q M_{g p c}}{Q M_{\text {resíduo }}}$ com os respectivos graus de liberdade.

Quando há uma adição de quadrados médios no numerador ou denominador do teste F, os graus de liberdade a serem utilizados devem ser estimados a partir da fórmula de Satterthwaite (1946). Portanto, os graus de liberdade $\mathrm{n}_{1}, \mathrm{n}_{2}, \mathrm{n}_{3}, \mathrm{n}_{4}, \mathrm{n}_{5}$ e $\mathrm{n}_{6}$ foram calculados da seguinte forma: 


$$
\begin{aligned}
& n_{1}=\frac{\left(Q M_{g}+Q M_{b g p}+Q M_{g p c}\right)^{2}}{\left(\frac{Q M_{g}}{I-1}\right)^{2}+\left(\frac{Q M_{b g p}}{(J-1)(I-1)(K-1)}\right)^{2}+\left(\frac{Q M_{g p c}}{(I-1)(K-1)(L-1)}\right)^{2}} \\
& n_{2}=\frac{\left(Q M_{g p}+Q M_{g c}+Q M_{b g}\right)^{2}}{\left(\frac{Q M_{g p}}{(I-1)(K-1)}\right)^{2}+\left(\frac{Q M_{g c}}{(I-1)(L-1)}\right)^{2}+\left(\frac{Q M_{b g}}{(I-1)(J-1)}\right)^{2}} \\
& \mathrm{n}_{3}=\frac{\left(\mathrm{QM}_{\mathrm{p}}+\mathrm{QM}_{\mathrm{bgp}}\right)^{2}}{\left(\frac{\mathrm{QM}_{\mathrm{p}}}{(\mathrm{K}-1)}\right)^{2}+\left(\frac{\mathrm{QM}_{\mathrm{bgp}}}{(\mathrm{J}-1)(\mathrm{I}-1)(\mathrm{K}-1)}\right)^{2}} ; \mathrm{n}_{4}=\frac{\left(\mathrm{QM}_{\mathrm{gp}}+\mathrm{QM}_{\mathrm{bp}}\right)^{2}}{\left(\frac{\mathrm{QM}_{\mathrm{gp}}}{(\mathrm{I}-1)(\mathrm{K}-1)}\right)^{2}+\left(\frac{\mathrm{QM}_{\mathrm{bp}}}{(\mathrm{J}-1)(\mathrm{K}-1)}\right)^{2}} ; \\
& n_{5}=\frac{\left(Q M_{g p}+Q M_{\text {residuo }}\right)^{2}}{\left(\frac{Q M_{g p}}{(I-1)(K-1)}\right)^{2}+\left(\frac{Q M_{\text {residuo }}}{I K(L-1)(J-1)}\right)^{2}} ; \mathrm{e} \\
& n_{6}=\frac{\left(Q M_{b g p}+Q M_{g p c}\right)^{2}}{\left(\frac{Q M_{b g p}}{(J-1)(I-1)(K-1)}\right)^{2}+\left(\frac{Q M_{g p c}}{(I-1)(K-1)(L-1)}\right)^{2}} \text {. }
\end{aligned}
$$

Vale ressaltar que foram realizadas análises prévias para verificar o comportamento dos dados quanto à obediência das premissas básicas do modelo matemático (Eisenhart, 1947): a) os parâmetros do modelo estatístico devem ser aditivos, ou seja, os efeitos se somarem; b) os erros experimentais devem ser independentes, ou seja, a probabilidade de que o erro de uma observação qualquer ter um particular valor não deve depender dos valores dos erros de outras observações; c) os erros experimentais devem ter uma variância comum, pois admitindo isso como verdadeiro, é possível usar um erro médio para todas as comparações de tratamentos; d) os erros experimentais devem ser normalmente distribuídos.

Entretanto, como tais condições, na prática, raramente são verificadas, prejudicando a aplicação dos testes de significância, alguns procedimentos podem ser 
utilizados com o fim de reparar, pelo menos aproximadamente, a falta de verificação dessas condições, como, por exemplo, mudar a escala de medida por uma transformação adequada (Gomes, 1990; Steel et al., 1997; Ferreira, 2000; Ramalho et al., 2000; Montgomery, 2001).

De acordo com alguns resultados encontrados, certas análises tiveram que ser realizadas seguindo o delineamento em blocos casualizados com parcelas subdivididas. Portanto, foi adotado o seguinte modelo estatístico:

$$
Y_{i j k}=\mu+g_{i}+b_{j}+(g b)_{i j}+f_{k}+g f_{i k}+e_{i j k}
$$

sendo:

$Y_{i j k}$ o valor fenotípico do i-ésimo indivíduo na repetição j, na posição de folha k;

$\mu$ a média geral do experimento;

$g_{i}$ o efeito do genótipo i;

$b_{j}$ o efeito do bloco $\mathrm{j}$;

$(g b)_{i j}$ o efeito da interação entre genótipo e bloco;

$f_{k}$ o efeito da posição da folha avaliada;

$g f_{i k}$ o efeito da interação entre tratamento e a posição da folha avaliada;

$e_{i j k}$ o erro aleatório associado a observação $Y_{i j k}$.

Da mesma forma, as premissas normalmente associadas a esse modelo considerado são:

(i) $G_{i} \sim \mathrm{N}\left(0, \sigma_{\mathrm{g}}^{2}\right)$, independentes; 
(ii) $\mathrm{B}_{\mathrm{j}} \sim \mathrm{N}\left(0, \sigma_{\mathrm{b}}^{2}\right)$, independentes;

(iii) $\mathrm{GB}_{\mathrm{ij}} \sim \mathrm{N}\left(0, \sigma_{\mathrm{gb}}^{2}\right)$, independentes;

(iv) $\mathrm{F}_{\mathrm{k}}$, fixo, $\therefore \mathrm{E}\left(\mathrm{f}_{\mathrm{k}}\right)=\mathrm{f}_{\mathrm{k}}, \mathrm{E}\left(\mathrm{f}_{\mathrm{k}}^{2}\right)=\mathrm{f}_{\mathrm{k}}^{2} \mathrm{e} \sum_{\mathrm{k}} \mathrm{f}_{\mathrm{k}}=0$;

(v) $\mathrm{GF}_{\mathrm{ik}} \sim \mathrm{N}\left(0, \sigma_{\mathrm{gf}}^{2}\right)$, independentes;

(xii) $e_{i j k} \sim\left(0, \sigma^{2}\right)$, independentes; e

(xiii) $G_{i}, \mathrm{~B}_{\mathrm{j}}, \mathrm{GB}_{\mathrm{ij}}$, e $e_{i j k}$ são efeitos aleatórios independentes, para todo i, j e k.

O esquema para as análises de variâncias considerando o modelo apresentado encontra-se no Quadro 2 (Barbin, 1993).

Quadro 2. Esquema das análises de variâncias utilizando delineamento em blocos casualizados com parcelas subdivididas, indicando os graus de liberdade, quadrados médios (QM) e suas respectivas esperanças $\mathrm{E}(\mathrm{QM})$

\begin{tabular}{cccc}
\hline Fonte de Variação & Graus de liberdade & $\mathrm{QM}$ & $\mathrm{E}(\mathrm{QM})^{1}$ \\
\hline Blocos & $\mathrm{J}-1$ & $Q M_{b}$ & $\sigma^{2}+K \sigma_{g b}^{2}+I K \sigma_{b}^{2}$ \\
Genótipos & $\mathrm{I}-1$ & $Q M_{g}$ & $\sigma^{2}+J \sigma_{g p}^{2}+K \sigma_{g b}^{2}+J K \sigma_{g}^{2}$ \\
Blocos x Genótipos & $(\mathrm{I}-1)(\mathrm{J}-1)$ & $Q M_{b g}$ & $\sigma^{2}+K \sigma_{g b}^{2}$ \\
Posição da Folha & $(\mathrm{K}-1)$ & $Q M_{p}$ & $\sigma^{2}+J \sigma_{g p}^{2}+I J \Phi_{p}$ \\
Genótipo x Posição & $(\mathrm{I}-1)(\mathrm{K}-1)$ & $Q M_{g p}$ & $\sigma^{2}+J \sigma_{g p}^{2}$ \\
\hline Resíduo & $\mathrm{I}(\mathrm{K}-1)(\mathrm{J}-1)$ & $Q M_{\text {resíduo }}$ & $\sigma^{2}$ \\
\hline Total & $\mathrm{IJK}-1$ & &
\end{tabular}

${ }^{1}$ Onde $\Phi_{p}=\frac{\sum_{k} p_{k}^{2}}{K-1}$

Com base nas esperanças dos quadrados médios, os testes $\mathrm{F}$ realizados a partir desse modelo são: 
- Teste F para o fator genótipo: $\frac{Q M_{g}+Q M_{\text {residuo }}}{Q M_{g p}+Q M_{b g}}$, com $\mathrm{n}_{1}$ e $\mathrm{n}_{2}$ graus de liberdade;

- Para o fator posição das folhas: $\frac{Q M_{p}}{Q M_{g p}}$, com os respectivos graus de liberdade;

- Para o fator interação genótipo x posição: $\frac{Q M_{g p}}{Q M_{\text {resíduo }}}$ com os respectivos graus de liberdade;

Portanto, os graus de liberdade $\mathrm{n}_{1}, \mathrm{n}_{2}$ devem ser calculados da seguinte forma (Satterthwaite, 1946):

$$
n_{1}=\frac{\left(Q M_{g}+Q M_{\text {residuo }}\right)^{2}}{\left(\frac{Q M_{g}}{(I-1)}\right)^{2}+\left(\frac{Q M_{\text {residuo }}}{I(K-1)(J-1)}\right)^{2}} \text { e } n_{2}=\frac{\left(Q M_{g p}+Q M_{b g}\right)^{2}}{\left(\frac{Q M_{g p}}{(I-1)(K-1)}\right)^{2}+\left(\frac{Q M_{b g}}{(I-1)(J-1)}\right)^{2}} \text {. }
$$

\subsubsection{Análise conjunta das avaliações realizadas com 0 isolado “18b”}

Para se realizar uma análise conjunta, envolvendo diferentes experimentos, devem ser verificadas algumas premissas, como a utilização de um mesmo delineamento estatístico, inclusão dos mesmos tratamentos e se há homogeneidade das variâncias entre os experimentos. De acordo com Gomes (1990), se existir uma razão entre os quadrados médios dos resíduos inferior a 7,0, pode-se realizar a análise conjunta dos dois experimentos. Entretanto, Ferreira (2000) relata que este valor deveria ser 4,0, para que a análise fosse realizada sem restrições.

Como o delineamento utilizado por Lopes (2003) foi em blocos casualizados e os dados fenotípicos de cada indivíduo se referem à média das três folhas de cada planta, os dados deste trabalho foram convertidos para ficarem sob o mesmo delineamento. Dessa 
forma, desconsiderando o efeito de posição das folhas, foi obtida, a média das três folhas, dentro de cada repetição, para compor os valores da cada parcela.

Assim, inicialmente, foram realizadas análises de variância para cada experimento individualmente, considerando o modelo aleatório. As análises foram realizadas de acordo com o seguinte modelo estatístico:

$$
Y_{i j}=\mu+t_{i}+b_{j}+e_{i j}, \text { sendo: }
$$

$Y_{i j}$ o valor fenotípico do i-ésimo indivíduo na repetição j;

$\mu$ a média geral do experimento;

$t_{i}$ o efeito do tratamento $\mathrm{i}$;

$b_{j}$ o efeito do bloco $\mathrm{j}$;

$e_{i j}$ o erro aleatório associado a observação $Y_{i j}$.

As premissas normalmente associadas a esse modelo são:

(i) $\mathrm{T}_{\mathrm{i}} \sim \mathrm{N}\left(0, \sigma_{\mathrm{t}}^{2}\right)$, independentes;

(ii) $\mathrm{B}_{\mathrm{j}} \sim \mathrm{N}\left(0, \sigma_{\mathrm{b}}^{2}\right)$, independentes;

(iii) $\mathrm{e}_{\mathrm{ij}} \sim \mathrm{N}\left(0, \sigma^{2}\right)$, independentes;

(iv) $T_{i}, B_{j}$ e $e_{i j}$ são efeitos aleatórios independentes, para todo i e j.

Ao se verificar a adequação dos dados quanto às premissas básicas de uma análise de variância, foi verificado que a transformação da escala dos dados deveria ser do tipo logarítmica em ambos experimentos (Montgomery, 2001).

Sendo possível realizar a análise conjunta, foi utilizado o seguinte modelo estatístico, considerando os efeitos aleatórios:

$$
Y_{i j k}=\mu+p_{k}+b_{j(k)}+t_{i}+p t_{i k}+e_{i j k}, \text { sendo: }
$$


$Y_{i j}$ o valor fenotípico do i-ésimo indivíduo na repetição j, na época k;

$\mu$ a média geral;

$p_{k}$ o efeito da época $\mathrm{k}$;

$b_{j(k)}$ o efeito do bloco j dentro da época $\mathrm{k}$;

$t_{i}$ o efeito do tratamento i;

$p t_{i k}$ o efeito da interação entre o tratamento i e a época k;

$e_{i j k}$ o erro aleatório associado a observação $\mathrm{Y}_{\mathrm{ijk}}$.

As premissas normalmente associadas a esse modelo são:

(i) $\mathrm{P}_{\mathrm{k}} \sim \mathrm{N}\left(0, \sigma_{\mathrm{e}}^{2}\right)$, independentes;

(ii) $B_{j(k)} \sim \mathrm{N}\left(0, \sigma_{b(p)}^{2}\right)$, independentes;

(iii) $\mathrm{T}_{\mathrm{i}} \sim \mathrm{N}\left(0, \sigma_{\mathrm{t}}^{2}\right)$, independentes;

(iv) $\mathrm{PT}_{\mathrm{ik}} \sim \mathrm{N}\left(0, \sigma_{\mathrm{te}}^{2}\right)$, independentes;

(v) $\mathrm{e}_{\mathrm{ijk}} \sim \mathrm{N}\left(0, \sigma^{2}\right)$, independentes;

(vi) $\mathrm{P}_{\mathrm{k}}, B_{j(k)}, \mathrm{T}_{\mathrm{i}}, \mathrm{PT}_{\mathrm{ik}}$ e $\mathrm{e}_{\mathrm{ijk}}$ são efeitos aleatórios independentes, para todo i, j e k.

Novamente, os dados dos dois experimentos foram utilizados em conjunto para verificar o seu comportamento quanto à obediência das premissas básicas do modelo matemático. A análise foi realizada utilizando o programa estatístico SAS (SAS Institute Inc., 1990). 


\subsubsection{Genotipagem molecular dos indivíduos $\mathbf{F}_{1}$}

A população analisada por Lopes (2003) continha 117 indivíduos e os dois genitores. Entretanto, mesmo recebendo os tratamentos culturais condizentes com a cultura, em casa de vegetação, algumas plantas acabaram morrendo. Neste trabalho, para a realização de novas avaliações fenotípicas foram incluídos novos indivíduos e, com isso, foi necessária a realização de novas genotipagens. Portanto, a população segregante, para fins de mapeamento, passou a ser composta por 160 indivíduos. Sementes remanescentes do cruzamento IAPAR-06 x IAPAR-123 foram usadas para obtenção de tais indivíduos adicionais.

\subsubsection{Extração do DNA genômico}

O DNA total de 45 indivíduos (43 indivíduos $\mathrm{F}_{1}$ e os dois genitores) foi extraído utilizando o método CTAB (brometo de cetiltrimetilamônio) descrito por Murray \& Thompson (1980), com modificações. Folhas jovens e frescas foram lavadas individualmente com água destilada, e secas com papel absorvente, antes de iniciar o processo de extração.

Foram utilizadas aproximadamente $250 \mathrm{mg}$ de tecido fresco de cada planta. Após a maceração em nitrogênio líquido, o material foi colocado em tubos para centrífuga (Eppendorf) de $2 \mathrm{~mL}$, contendo $1 \mathrm{~mL}$ de tampão de extração CTAB previamente aquecido a $65{ }^{\circ} \mathrm{C}$. O material foi homogeneizado com auxílio de uma espátula, e mantido a $65{ }^{\circ} \mathrm{C}$ por 30 minutos, em banho-maria, com agitações brandas e periódicas. Os tubos foram retirados do banho-maria e foi acrescentada uma solução de $700 \mu \mathrm{L}$ de clorofórmio : álcool isoamílico $(24: 1)$.

Por movimentos de inversões dos tubos essa mistura foi homogeneizada e depois colocada em uma microcentrífuga Eppendorf sob 14000 rpm por 15 minutos. Foram 
recuperados $700 \mu \mathrm{L}$ do sobrenadante, os quais foram transferidos para novos tubos de 2 $\mathrm{mL}$. Para a precipitação do DNA, foram acrescentados $520 \mu \mathrm{L}$ de isopropanol, invertendo-se cuidadosamente os tubos, mantendo-os por 30 minutos sob temperatura ambiente. O DNA precipitado foi recuperado por meio de centrifugação sob $1000 \mathrm{rpm}$ por 10 minutos. O isopropanol foi descartado e os resíduos removidos com o auxílio de uma espátula.

Foi adicionado aos tubos $1 \mathrm{~mL}$ de solução de lavagem, deixando o DNA em imersão por 30 minutos. A solução de lavagem foi descartada e os resíduos foram eliminados seguindo os mesmos procedimentos para eliminação do isopropanol.

Foram acrescentados $100 \mu \mathrm{L}$ de tampão TE (Tris-EDTA; Tris: tris(hidroximetil)-aminometano; EDTA: ácido etileno diamino tetracético) aos tubos, os quais ficaram sob temperatura de aproximadamente $4^{\circ} \mathrm{C}$ por cerca de 2 horas, até a ressuspensão completa do DNA que foi novamente precipitado acrescentando-se $50 \mu \mathrm{L}$ de acetato de amônio (7,5 M) e $375 \mu \mathrm{L}$ de etanol absoluto. O conteúdo de cada tubo foi misturado por inversões suaves e o DNA precipitado foi recuperado através de centrifugação sob $14000 \mathrm{rpm}$ por 15 minutos. O sobrenadante foi descartado e uma última lavagem foi realizada adicionando-se $500 \mu \mathrm{L}$ de etanol $70 \%$ durante 20 minutos. O etanol foi descartado e os resíduos eliminados. Dessa forma, o DNA de cada planta foi ressuspendido em $100 \mu \mathrm{L}$ de tampão TE.

\subsubsection{Quantificação do DNA genômico}

A quantificação foi realizada após eletroforese $(3 \mathrm{Volts} / \mathrm{cm})$ de alíquotas de cada amostra, comparando-as com uma série de concentrações conhecidas de DNA (20, 40, 60, 80 e $100 \mathrm{ng}$ ) do fago Lambda (Invitrogen - BRL), realizada em géis de agarose a $1,0 \%(\mathrm{p} / \mathrm{v})$. 
A concentração de DNA foi estimada a partir da comparação visual das intensidades das bandas, reveladas pela coloração com brometo de etídeo $(1,0 \mu \mathrm{g} / \mathrm{mL})$. A fluorescência é proporcional à concentração de DNA. Dessa forma, foi obtida, para cada amostra, uma diluição contendo $15 \mathrm{ng} / \mu \mathrm{L}$.

\subsubsection{Genotipagem para marcadores AFLP}

O DNA genômico foi digerido através de uma combinação de duas enzimas, sendo sempre uma de corte freqüente e uma de corte raro. Duas combinações de enzimas foram utilizadas na digestão: combinações envolvendo enzimas EcoR1 e Pst1 (cortes raros) com a enzima Mse 1 (cortes freqüentes).

O protocolo utilizado para amplificação foi $\mathrm{o}$ proposto no site http://www.msu.edu/user/hazensam/aflp/AFLPprotocolMSU.html, adaptado por Lopes (2003), e o protocolo utilizado para revelação dos géis foi o proposto por Creste et al., (2001). A seguir serão descritas todas as etapas para a genotipagem dos 45 indivíduos da população segregante.

Considerando, por exemplo, a combinação Mse1 com EcoR1, para cada reação foram utilizados $250 \mathrm{ng}$ de DNA genômico; 5,0 $\mu \mathrm{L}$ de tampão "One Phor All” 10X (OPA; Amersham); 0,5 $\mu \mathrm{L}$ de solução de albumina de soro bovino (BSA) $(10 \mu \mathrm{g} / \mu \mathrm{L})$; $1,25 \mu \mathrm{L}$ da enzima Mse1 (4 unidades/ $\mu \mathrm{L}$; New England Biolabs) e 0,5 $\mu \mathrm{L}$ da enzima EcoR1 (10 unidades/ $\mu \mathrm{L}$; Invitrogen). O volume foi completado para $50 \mu \mathrm{L}$ com água ultrapura autoclavada. As reações de restrição foram realizadas sob $37{ }^{\circ} \mathrm{C}$ durante 3 horas, sendo cuidadosamente agitadas a intervalos de uma hora. Após a digestão, as reações foram submetidas a um tratamento térmico por 15 minutos a $70{ }^{\circ} \mathrm{C}$ para inativar as enzimas de restrição.

Para verificar o resultado da digestão, $10 \mu \mathrm{L}$ da reação de digestão foram submetidos à eletroforese em gel de agarose $1 \%$ por 3 horas em tampão TEB (tris 0,09 
M, ácido bórico 0,09 M, EDTA $2 \mathrm{mM}) 1 \mathrm{X}(2,5 \mathrm{~V} / \mathrm{cm})$. Após a corrida, os géis foram corados com brometo de etídeo $(1,0 \mu \mathrm{g} / \mathrm{mL})$ durante 15 minutos e posteriormente fotografados sob luz UV.

Os adaptadores foram preparados em quantidade suficiente para a realização de ligações em 120 amostras. O preparo dos adaptadores se deu da seguinte forma: adaptador EcoR1 - Foram misturados: 3,4 $\mu \mathrm{L}(1 \mu \mathrm{g} / \mu \mathrm{L})$ de EcoR1-oligo 1 (5'CTC GTA GAC TGC GTA CC 3') e 3,0 $\mu \mathrm{L}(1 \mu \mathrm{g} / \mu \mathrm{L})$ de EcoR1-oligo 2 (5'AAT TGG TAC GCA GTC TAC 3'), 6,0 $\mu \mathrm{L}$ de tampão de PCR OPA 10X (“One Phor All”, Amersham) e 107,6 $\mu \mathrm{L}$ de água ultrapura autoclavada; adaptador Mse 1 - Foram misturados: 32,0 $\mu \mathrm{L}$ $(1,0 \mu \mathrm{g} / \mu \mathrm{L})$ de Mse1-oligo 1 (5'GAC GAT GAG TCC TGA G 3'); 28,0 $\mu \mathrm{L}(1,0 \mu \mathrm{g} / \mu \mathrm{L})$ de Mse1-oligo 2 (5'TAC TCA GGA CTC AT 3'); 7,0 $\mu \mathrm{L}$ do tampão de PCR OPA 10X (“Open Phor All”, Amersham) e 53,0 $\mu \mathrm{L}$ de água ultrapura autoclavada. Após os componentes serem misturados e homogeneizados, em um tubo de $500 \mu \mathrm{L}$, a solução foi submetida a uma seqüência de 10 minutos sob $65{ }^{\circ} \mathrm{C}$, 10 minutos sob $37{ }^{\circ} \mathrm{C}$ e 10 minutos sob $25^{\circ} \mathrm{C}$, sendo depois mantida sob $-20^{\circ} \mathrm{C}$.

Considerando apenas uma reação de ligação foram utilizados: $2,0 \mu \mathrm{L}$ do tampão da enzima T4 DNA ligase 5X (Invitrogen), 1,0 $\mu \mathrm{L}$ dos adaptadores das enzimas EcoR1 ou Pst 1, 1,0 $\mu \mathrm{L}$ do adaptador da enzima Mse 1, 1,0 $\mu \mathrm{L}$ de T4 DNA ligase (1 unidade/ $\mu \mathrm{L}$ , Invitrogen), 5,0 $\mu \mathrm{L}$ de água ultrapura autoclavada e $40 \mu \mathrm{L}$ da reação da digestão descrita acima. As reações de ligação foram realizadas sob $20^{\circ} \mathrm{C}$ durante 3 horas, sendo cuidadosamente agitadas a intervalos de 1 hora. As amostras foram armazenadas sob $20^{\circ} \mathrm{C}$.

Foram desenvolvidas duas reações consecutivas para a amplificação do DNA. Na primeira, reação de pré-amplificação, foram utilizados "iniciadores” de EcoR1 e Mse 1 ou de Pst1 e Mse1, com extensão de 1 nucleotídeo seletivo na extremidade 3'. Os produtos da reação de pré-amplificação foram diluídos e utilizados como molde ("template") na segunda reação de PCR, amplificação seletiva, na qual foram utilizados 3 nucleotídeos seletivos adicionados à extremidade 3' dos iniciadores, sendo o primeiro 
nucleotídeo correspondente àquele utilizado na pré-amplificação. Ambas reações foram efetuadas em termociclador PTC-100 (MJ Research).

Os iniciadores EcoR1 utilizados nas reações de pré-amplificação foram representados por $\mathrm{E}+\mathrm{N}$, sendo $\mathrm{N}$ o nucleotídeo seletivo adicionado ao terminal $3^{\prime}$ do iniciador. Os iniciadores das enzimas $M s e 1$ e Pst 1 foram representados por $\mathrm{M}+\mathrm{N}$ e $\mathrm{P}+\mathrm{N}$, respectivamente. Foram utilizadas 34 combinações de iniciadores (Quadro 4).

As reações de pré-amplificação foram compostas por: $0,5 \mu \mathrm{L}$ do iniciador da enzima de corte raro EcoR $1+\mathrm{N}$ oligo $(50 \mathrm{ng} / \mu \mathrm{L}), 0,5 \mu \mathrm{L}$ do iniciador da enzima de corte freqüente Mse $1+\mathrm{N}$ oligo $(50 \mathrm{ng} / \mu \mathrm{L}) ; 1,0 \mu \mathrm{L}$ de dNTP $10 \mathrm{mM}$ (Invitrogen); 2,0 $\mu \mathrm{L}$ de tampão sem $\mathrm{MgCl}_{2}$ 10X (Fermentas), 1,2 $\mu \mathrm{L} \mathrm{MgCl}_{2} 25 \mathrm{mM}$ (Fermentas), 0,6 $\mu \mathrm{L}$ de Taq DNA polimerase (5,0 unidades/ $\mu \mathrm{L}$; Fermentas) e $8,2 \mu \mathrm{L}$ de água ultrapura autoclavada. A esse coquetel de pré-amplificação foram adicionados $3,0 \mu \mathrm{L}$ da solução com o DNA digerido e ligado ao adaptador.

A pré-amplificação foi realizada de acordo com o seguinte protocolo: $94{ }^{\circ} \mathrm{C}, 2$ minutos (passo 1); $94{ }^{\circ} \mathrm{C}, 1$ minuto (passo 2, desnaturação); $56{ }^{\circ} \mathrm{C}, 1$ minuto (passo 3 , hibridização); e $72{ }^{\circ} \mathrm{C}, 1$ minuto (passo 4, extensão). Os passos 2 a 4 foram repetidos por 26 vezes. O ciclo final foi seguido de 5 minutos a $72{ }^{\circ} \mathrm{C}$. Os produtos da reação foram diluídos em $80 \mu \mathrm{L}$ de água ultrapura e armazenados sob $-20^{\circ} \mathrm{C}$.

$\mathrm{Na}$ amplificação seletiva foram utilizadas combinações de iniciadores EcoR1 com Mse 1 e Pst1 com Mse1, sendo ambos com extensão de 3 pares de bases adicionados ao adaptador na extremidade 3'. Nessas reações foram utilizados: 0,5 $\mu \mathrm{L}(50 \mathrm{ng} / \mu \mathrm{L})$ do iniciador da enzima de corte raro, EcoR $1+\mathrm{NNN}$ ou $P s t 1+\mathrm{NNN}, 0,6 \mu \mathrm{L}$ do iniciador da enzima de corte freqüente $M s e 1+\mathrm{NNN}(50 \mathrm{ng} / \mu \mathrm{L}), 0,8 \mu \mathrm{L}$ de dNTP $5 \mathrm{mM}$ (Invitrogen), 2,0 $\mu \mathrm{L}$ de tampão da Taq DNA polimerase 10X (Fermentas), $1,2 \mu \mathrm{L}$ de $\mathrm{MgCl}_{2} 25 \mathrm{mM}$ (Fermentas), 0,32 $\mu \mathrm{L}$ de Taq DNA polimerase (5 unidades / $\mu \mathrm{L}$; Fermentas), 12,28 $\mu \mathrm{L}$ de água ultrapura autoclavada e $1,5 \mu \mathrm{L}$ da reação de pré-amplificação diluído. O programa de amplificação foi realizado de acordo com o seguinte protocolo: inicialmente procedeu-se uma desnaturação inicial a $94{ }^{\circ} \mathrm{C}$ durante 2 minutos, seguida de 12 ciclos de 
$94{ }^{\circ} \mathrm{C}$ por 30 segundos; $65^{\circ} \mathrm{C}$ por 30 segundos, com redução de $0,7{ }^{\circ} \mathrm{C}$ por ciclo; $72{ }^{\circ} \mathrm{C}$ por 1 minuto, seguidos por 23 ciclos de $94{ }^{\circ} \mathrm{C}$ por 30 segundos; $56^{\circ} \mathrm{C}$ por 30 segundos e $72{ }^{\circ} \mathrm{C}$ por 1 minuto encerrando os ciclos com $72{ }^{\circ} \mathrm{C}$ por 2 minutos. Após o término, a reação foi mantida sob $4^{\circ} \mathrm{C}$, para ser realizada a corrida em eletroforese no dia seguinte, podendo ser armazenada sob $-20^{\circ} \mathrm{C}$, por período indeterminado.

As placas utilizadas na montagem do gel foram cuidadosamente limpas utilizando-se etanol 95\%. Na placa maior foram aplicados 1,4 mL de REPEL (Amersham), em duas etapas, sendo a primeira com $600 \mu \mathrm{L}$ e, após 5 minutos, uma segunda etapa com $800 \mu \mathrm{L}$. Após cada aplicação, o produto foi cuidadosamente espalhado, utilizando-se lenços de papel Kimwipes EX-L (Kimberly - Clark®), por toda a placa . Para o tratamento da placa menor, foram misturados, em tubo falcon de $15 \mathrm{~mL}$, $995 \mu \mathrm{L}$ de etanol 95\%, $5 \mu \mathrm{L}$ de ácido acético glacial e $5 \mu \mathrm{L}$ de BIND (Amersham). Em seguida, o produto foi aplicado sobre a placa e cuidadosamente espalhado utilizando os lenços de papel com movimentos circulares.

Para o preparo de 1 litro da solução matriz de poliacrilamida $6 \%$, foram utilizados $420 \mathrm{~g}$ de uréia, $200 \mathrm{~mL}$ de TEB $5 \mathrm{X}, 150 \mathrm{~mL}$ de acrilamida/bisacrilamida $40 \%$ (19:1), sendo o volume final ajustado para 1 L com água ultrapura. A matriz foi filtrada em membrana HA em éster de celulose, com $0,45 \mu \mathrm{m}$ de poro e $47 \mathrm{~mm}$ de diâmetro (Millipore), e armazenada em frascos de vidro de cor âmbar, envoltos em papel alumínio e mantidos em refrigerador.

Para o preparo de um gel utilizou-se $120 \mathrm{~mL}$ da solução matriz, $120 \mu \mathrm{L}$ de TEMED (Invitrogen) e $800 \mu \mathrm{L}$ de persulfato de amônio (Sigma) 10\%. A cuba contendo ambas as placas e o gel foi montado e deixado para polimerização durante 12 horas. Para se evitar o ressecamento do gel na região da aplicação do pente, foi colocado um lenço de papel embebido com solução TEB 1X.

Juntamente a $20 \mu \mathrm{L}$ do produto final de cada reação de amplificação, foram adicionados $10 \mu \mathrm{L}$ da seguinte solução: $10 \mu \mathrm{L}$ de tampão de carregamento (formamida 98\%, EDTA 0,5M pH 8,0; azul de bromofenol 0,002\% p/v e xileno cianol 0,002\% p/v). 
Depois de misturadas as soluções, as amostras foram desnaturadas a $95^{\circ} \mathrm{C}$ por 5 minutos. Antes da aplicação das amostras, o gel foi submetido a uma eletroforese inicial ("précorrida") sob uma potência constante de $80 \mathrm{~W}$ por 1 hora. Após esse passo, os poços foram cuidadosamente limpos, com a própria solução de TEB 1X, utilizando uma agulha acoplada a uma seringa e então iniciada a aplicação de $15 \mu \mathrm{L}$ de cada amostra. Foi utilizado o sistema eletroforético "Sequi-Gen GT" (Biorad) de 38 x $50 \mathrm{~cm}$ e pentes para 50 ou 65 amostras.

Para a corrida das amostras, na parte superior da cuba foi utilizado TEB 1X e, na parte inferior, TEB $1 \mathrm{X} /$ acetato de sódio $0,375 \mathrm{M}$. A corrida eletroforética foi desenvolvida a $80 \mathrm{~W}$ (potência constante, 40-50 V/cm) utilizando tampão TEB 1X. A corrida foi interrompida após 4,5 horas.

A coloração do gel foi com base no protocolo proposto por Creste et al., (2001), modificado por Lopes (2003). Após a eletroforese, as placas foram cuidadosamente separadas e o gel aderido a placa menor foi corado com nitrato de prata. Para tanto, o gel foi imerso em 2 L em solução para fixação (etanol 10\% e ácido acético 1\%), agitando lentamente por 10 minutos. Após a fixação, foi realizada uma lavagem com água ultrapura gelada, durante 1 minuto, com leve agitação.

O procedimento de pré-tratamento foi realizado com $2 \mathrm{~L}$ de solução de oxidação (ácido nítrico 1,5\%) durante 3 minutos. $\mathrm{O}$ gel foi então lavado sob lenta agitação em $2 \mathrm{~L}$ de água ultrapura, durante 1 minuto. A impregnação do gel foi realizada com a solução de nitrato de prata $\left(\mathrm{AgNO}_{3}\right)$ 0,2\% durante 20 minutos, sob agitação leve. Duas novas lavagens foram realizadas, com água ultrapura, com duração de 30 segundos cada.

A revelação dos géis se deu em solução contendo $2 \mathrm{~L}$ de água ultrapura, $60 \mathrm{~g}$ de carbonato de sódio anidro (Mallinckrodt) e 1,4 mL de formaldeído (Promega) (37\%). Nesta etapa, 1 litro foi aplicado sobre o gel até começarem a surgir as bandas. Após este passo, a solução foi descartada e o outro litro adicionado para finalizar o processo de revelação. Após a revelação da placa, a solução foi descartada. 
O bloqueio da revelação foi realizado em solução de ácido acético $5 \%$ durante 5 minutos, sob agitação leve, seguindo-se uma nova lavagem com água ultrapura durante 1 minuto. Após este passo, para a secagem do gel, a placa foi colocada em posição vertical em um local seco e arejado, sob temperatura ambiente, possibilitando a análise das bandas presentes.

O peso molecular dos locos polimórficos foi determinado a partir de uma equação de regressão, obtida com base nas distâncias de migração dos fragmentos de DNA de um padrão de peso molecular de 100 pb (Invitrogen).

As seqüências dos adaptadores e dos iniciadores utilizados na avaliação das combinações de pré-amplificação e amplificação seletiva estão no Quadro 3.

Quadro 3. Seqüência dos adaptadores e iniciadores utilizados nas reações de préamplificação

\begin{tabular}{|c|c|}
\hline Especificação & Seqüência \\
\hline Adaptador EcoR1 & $\begin{array}{l}5^{\prime} \text { - CTCGTAGACTGCGTACC -3' } \\
3^{\prime}-\text { - CATCTGACGCATGGTTAA -5' }\end{array}$ \\
\hline Iniciadores da pré-amplificação EcoR1 & $\begin{array}{l}\text { 5'- GACTGCGTACCAATTC } \underline{\mathbf{A}}-3^{\prime} \text { ou } \\
\text { 5'- GACTGCGTACCAATTC } \underline{\mathbf{T}}-3^{\prime}\end{array}$ \\
\hline Adaptador Mse 1 & $\begin{array}{c}5^{\prime}-\text { GACGATGAGTCCTGAG -3' } \\
\text { 3'- TACTCAGGACTCAT - } 5^{\prime} \\
\end{array}$ \\
\hline Iniciadores da pré-amplificação $M s e 1$ & 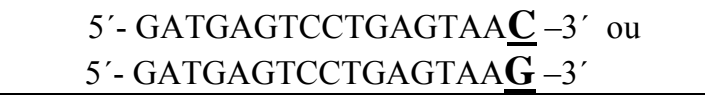 \\
\hline Adaptador Pst1 & $\begin{array}{c}\text { 5' }^{\prime} \text { - CTCGTAGACTGCGTACATGCA }-3^{\prime} \\
\text { 3'- CATCTGACGCATGT -5' } \\
\end{array}$ \\
\hline Iniciador da pré-amplificação Pst1 & 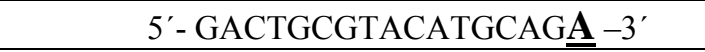 \\
\hline
\end{tabular}

Para realizar a identificação dos marcadores foi adotado um código no qual os dois primeiros caracteres são as letras que correspondem às enzimas de restrição (EcoR1 $=\mathrm{E}, P s t 1=\mathrm{P}$ e $M s e 1=\mathrm{M})$, o terceiro e o quarto caracteres são números que identificam as combinações de acordo com a variação nas extensões dos iniciadores (Quadro 4). O código de identificação dos locos AFLP é composto pelos quatro caracteres que identificam a combinação, seguidos do tamanho do fragmento do loco em pares de base. 
Quadro 4. Códigos atribuídos às 34 combinações de iniciadores AFLP usadas para as amplificações seletivas. Em negrito estão os 3 nucleotídeos seletivos adicionados à extremidade $3^{\prime}$ dos iniciadores, para a realização da amplificação seletiva

\begin{tabular}{|c|c|}
\hline Códigos & Combinações \\
\hline EM01 & 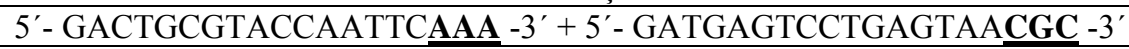 \\
\hline EM02 & 5'- GACTGCGTACCAATTCAAA -3' + 5' - GATGAGTCCTGAGTAACTA -3' \\
\hline EM03 & 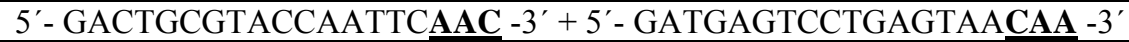 \\
\hline EM04 & 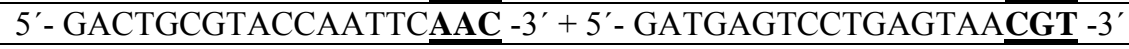 \\
\hline EM05 & 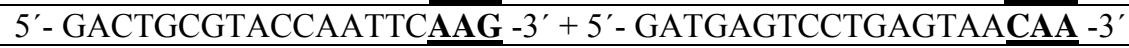 \\
\hline EM06 & 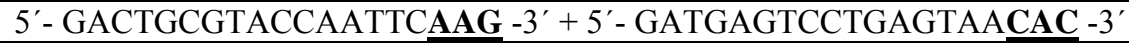 \\
\hline EM07 & 5'- GACTGCGTACCAATTCEAC $-3^{\prime}+$ 5' $^{\prime}$ - GATGAGTCCTGAGTAA $\overline{\overline{\mathbf{C T C}}}-3^{\prime}$ \\
\hline EM08 & 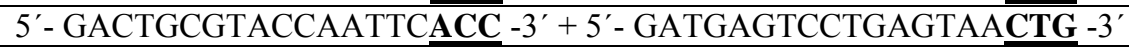 \\
\hline EM09 & 5' - GACTGCGTACCAATTCACC -3' + 5' - GATGAGTCCTGAGTAACTT -3' \\
\hline EM10 & 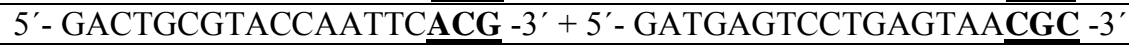 \\
\hline EM11 & 5' - GACTGCGTACCAATTC $\underline{A C G}-3^{\prime}+5^{\prime}$ - GATGAGTCCTGAGTAA $\underline{\mathbf{C T T}}-3^{\prime}$ \\
\hline EM12 & 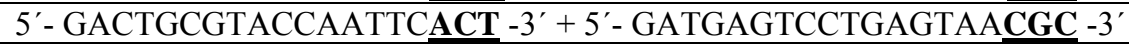 \\
\hline EM13 & 5' - GACTGCGTACCAATTC \\
\hline EM14 & 5'- GACTGCGTACCAATTCA $\overline{\overline{\mathbf{A G G}}}-3^{\prime}+5^{\prime}$ - GATGAGTCCTGAGTAA $\overline{\overline{\mathbf{C A G}}}-3^{\prime}$ \\
\hline EM15 & 5' - GACTGCGTACCAATTCEAG $-3^{\prime}+5^{\prime}$ - GATGAGTCCTGAGTAA $\overline{\overline{\mathbf{C T T}}}-3^{\prime}$ \\
\hline EM16 & 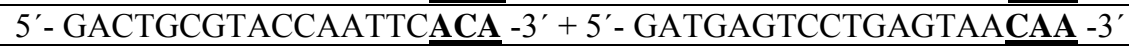 \\
\hline EM17 & 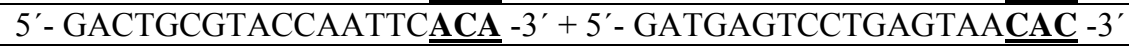 \\
\hline EM18 & 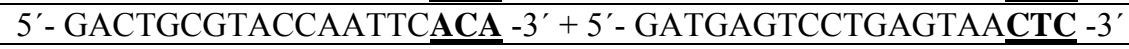 \\
\hline EM19 & 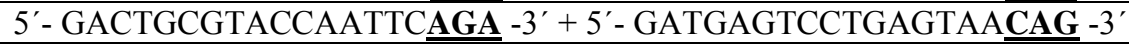 \\
\hline EM20 & 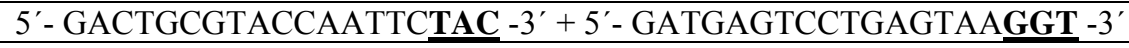 \\
\hline EM21 & 5' - GACTGCGTACCAATTCTAG $-3^{\prime}+5^{\prime}$ - GATGAGTCCTGAGTAAGCT $-3^{\prime}$ \\
\hline EM22 & 5'- GACTGCGTACCAATTCEAT $-3^{\prime}+5^{\prime}$ - GATGAGTCCTGAGTAAGGC $-3^{\prime}$ \\
\hline EM23 & 5'- GACTGCGTACCAATTCETA $-3^{\prime}+$ 5' $^{\prime}$ - GATGAGTCCTGAGTAAGGT $-3^{\prime}$ \\
\hline EM24 & 5' - GACTGCGTACCAATTC \\
\hline PM01 & 5' - GACTGCGTACATGCAGACA $-3^{\prime}+5^{\prime}$ - GATGAGTCCTGAGTAA $\underline{\overline{\mathbf{C A C}}}-3^{\prime}$ \\
\hline PM02 & 5' - GACTGCGTACATGCAGACA -3' + 5' - GATGAGTCCTGAGTAACAG -3' \\
\hline PM03 & 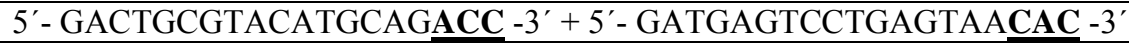 \\
\hline PM04 & 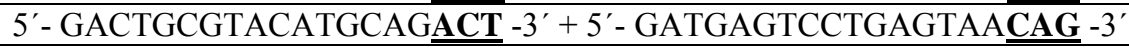 \\
\hline PM05 & 5' - GACTGCGTACATGCAGAGC -3' + 5' - GATGAGTCCTGAGTAAEGT -3' \\
\hline PM06 & 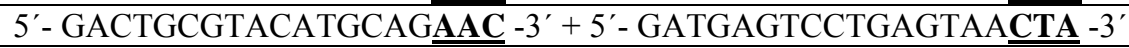 \\
\hline PM07 & 5' - GACTGCGTACATGCAGACG -3' + 5' - GATGAGTCCTGAGTAA $\overline{\overline{\mathbf{C T G}}}-3^{\prime}$ \\
\hline PM08 & 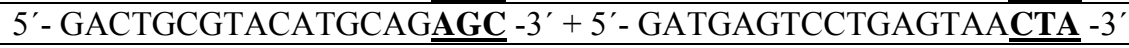 \\
\hline PM09 & 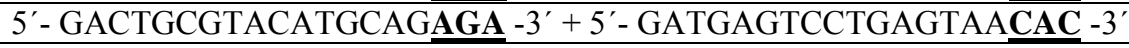 \\
\hline PM10 & 5' - GACTGCGTACATGCAGAAA -3' + 5' - GATGAGTCCTGAGTAA $\underline{\mathbf{C A C}}$-3' \\
\hline
\end{tabular}

Como neste trabalho havia a necessidade de se repetir os padrões moleculares obtidos por Lopes (2003), com o intuito de se aumentar o número de indivíduos da população segregante, em algumas combinações foram utilizadas algumas amostras das reações realizadas por Lopes (2003), armazenadas sob $-20^{\circ} \mathrm{C}$. A intenção era verificar a repetibilidade dessa técnica molecular. 


\subsubsection{Construção dos mapas de ligação}

Considerando um cruzamento entre dois acessos heterozigóticos e marcadores dominantes AFLP, podem ser observados três tipos de segregação: a) Segregação do tipo (ㅇ) $a b \times a a\left({ }^{\Uparrow}\right)$, ou seja, informativo por parte do genitor feminino, cuja segregação na progênie é do tipo 1:1, como resultado da heterozigose desse loco no genitor feminino e homozigose no genitor masculino; b) Segregação do tipo () $a a$ x $a b\left({ }_{0}\right)$, ou seja, informativo por parte do genitor masculino, cuja segregação na progênie é do tipo $1: 1$, como resultado da heterozigose desse loco no genitor masculino e homozigose no genitor feminino; c) Segregação do tipo (†) $a 0$ × $a 0(\widehat{\overbrace{}})$, ou seja, loco heterozigótico em ambos genitores, cuja segregação esperada na progênie é do tipo $3: 1$.

Neste trabalho foram utilizados os marcadores com segregação 1:1 e 3:1. As análises de ligação e de distorção na segregação mendeliana foram realizadas com o auxílio do programa computacional JoinMap ${ }^{\circledR}$, versão 3.0, (Van Ooijen \& Voorrips, 2001). O procedimento de mapeamento utilizado foi o CP ("Cross Pollinators"), o qual é recomendado para o mapeamento de uma população resultante de um cruzamento entre dois genitores heterozigóticos, cujas fases de ligação dos locos são originalmente desconhecidas.

Para tanto, os dados do genitor IAPAR-06 receberam a codificação $<\operatorname{lm} \times \mathrm{mm}>$ sendo que genótipos $\mathrm{Im}$ e $\mathrm{mm}$ corresponderam à presença e ausência de bandas, respectivamente. Os dados do genitor IAPAR-123 receberam a codificação $<n n \times n p>$, sendo que os genótipos $n p$ e $n n$ corresponderam à presença e ausência de bandas, respectivamente. Para os marcadores bi-parentais foi adotada a codificação foi $<h k \mathrm{x}$ $h k>$, sendo a segregação do tipo $(h-, k k)$; os genótipos $h$ - e $k k$ corresponderam à presença e ausência de bandas, respectivamente.

A utilização de marcadores com segregação 3:1 é inédita em estudos de mapeamento de Passiflora uma vez que os trabalhos anteriores desenvolvidos por Carneiro et al. (2002) e Lopes (2003) se limitaram a usar as segregações do tipo 1:1. 


\subsubsection{Mapeamento de QRL}

Após a construção dos mapas de ligação foram obtidos os QRL com base no método de mapeamento múltiplo de QTL (Multiple QTL Models - MQM), proposto por Jansen (1993; 1994) e Jansen \& Stam (1994), utilizando o programa computacional MAPQTL 4.0 (Van Ooijen et al., 2000). Esse método de mapeamento combina o mapeamento por intervalo, o qual utiliza princípios de máxima verossimilhança, e regressão linear múltipla, que utiliza os marcadores como variáveis regressoras (cofatores).

$\mathrm{O}$ uso desses marcadores co-fatores torna-se interessante, pois com base em resultados de regressões múltiplas e considerando uma progênie de tamanho elevado, é verificado que o efeito de um QTL é absorvido somente pelos marcadores flanqueadores, e que os efeitos demonstrados pelas demais marcas próximas a este QTL são redundantes. Desde que as localizações dos QTL são geralmente desconhecidas, o próximo passo é se determinar quais marcas devem ser utilizadas como co-fatores no MQM e, dessa forma, procedimentos padrões para seleção de variáveis regressoras podem ser adotados (Jansen, 1994).

Como neste trabalho o número de marcadores é muito maior que o número de indivíduos utilizados, a análises de regressão envolvendo todas as marcas, não pôde ser realizada devido aos intrínsecos problemas matemáticos. Para eliminar esse tipo de problema, após a realização dos testes de marcas simples, somente os marcadores que estivessem ligados às variáveis fenotípicas, ao nível de 5\% de probabilidade, foram utilizadas nas análises de regressão múltipla.

Para a análise regressão múltipla foi utilizado o método de construção de modelos passo a passo ("stepwise") proposto por Draper \& Smith (1998), de forma que ficassem no modelo de regressão apenas aquelas marcas com evidências de estarem ligadas a algum QRL, evitando redundância de informação entre elas. Segundo Bearzoti (2000), de uma maneira simplificada, no processo "stepwise", inicialmente, coloca-se no 
modelo de regressão somente o marcador com maior valor de F parcial que tenha sido significativo. Em seguida, testa-se o marcador, dentre os candidatos a entrar no modelo, que tem o valor mais alto de F parcial, na presença do primeiro marcador. Dentre os marcadores do modelo recém formado, aqueles que apresentarem teste $F$ não significativo são retirados do modelo e os que apresentarem $\mathrm{F}$ significativos são mantidos. Estes testes são efetuados um por um, a cada passo. O processo continuará até que todos os marcadores candidatos a entrar no modelo sejam testados e até que todos os marcadores do modelo tenham $\mathrm{F}$ parciais significativos.

Tendo encontrado os marcadores co-fatores, o mapeamento foi realizado determinando os seguintes parâmetros: a) A distância entre duas posições consecutivas, nas quais foram realizados os testes de hipótese para presença de QRL, foi de $1 \mathrm{cM}$, ou seja, os testes foram realizadas a cada $1 \mathrm{cM}$ ao longo de cada grupo de ligação; b) $\mathrm{O}$ ponto de corte para declarar a presença de um QRL em uma determinada posição foi feito com base em testes de permutações como descrito por Churchil \& Doerge (1994), nos quais foram realizadas 1000 permutações usando o nível de significância de 5\%.

Vale relatar que o programa computacional MAPQTL não utiliza a estratégia do "window size" para o controle do "background" genético, durante os procedimentos de mapeamento dos QRL.

A função do window size é a de "proteger" o QTL que está sendo analisado dentro de um dado intervalo entre marcas no mapa. Considerando um window size de 10 $\mathrm{cM}$, significa que este intervalo estará protegido $10 \mathrm{cM}$ tanto à esquerda quanto à direita do efeito de possíveis QTL localizados em intervalos adjacentes. Portanto, nesse processo, evita-se que outros QTL inseridos no window size entrem como co-fator das análises. Esta situação vale para as marcas consideradas co-fatoras nas análises de regressão múltipla, pois se as mesmas estiverem dentro dos intervalos abrangidos pelo window size, os efeitos destas marcas não serão consideradas, evitando, portanto, a detecção de QTL fantasmas (Coelho \& $\operatorname{Silva}^{10}$, 2002).

\footnotetext{
${ }^{10}$ COELHO, A.S.G.; SILVA, H.D. Construção de mapas genéticos e mapeamento de QTL's. Piracicaba, 2002. 65p. (apostila).
} 
A estratégia do MAPQTL não é utilizar um window size que possa abranger várias marcas de uma só vez, mas retirar o efeito das marcas co-fatoras quando estas fizerem parte do determinado intervalo que está sendo analisado. Quando um determinado intervalo estiver sendo flanqueado por uma marca co-fatora, obtida pelas análises de regressão múltipla, essa marca será desconsiderada temporariamente nesta análise. Dessa forma, o conjunto de marcadores co-fatores do modelo de mapeamento sendo alterado, os testes de verossimilhança, para as hipóteses de ausência ou presença de QRL, são recalculados (J.W. van Ooijen - comunicação pessoal). 


\section{RESULTADOS E DISCUSSÃO}

\section{Considerações iniciais}

As médias dos dados referentes às temperaturas e umidades, coletados durante os dois experimentos de avaliação fenotípica, conduzidos em telado, estão na Tabela 2. Durante todos os dias em que as plantas ficaram no telado foram anotadas as temperaturas e umidades às 8:00, 12:00, 16:00 e 18:30 horas. Como o segundo experimento foi realizado entre 15/04/03 e 05/05/03, verificou-se que, em geral, as temperaturas apresentadas foram inferiores àquelas do primeiro experimento, conduzido entre 14/03/03 e 06/04/03. Da mesma forma, explica-se a umidade superior encontrada no segundo experimento, em determinados horários.

Tabela 2. Temperaturas e umidades médias, máximas e mínimas apresentadas durante o primeiro e o segundo experimento de inoculação e desenvolvimento da bacteriose

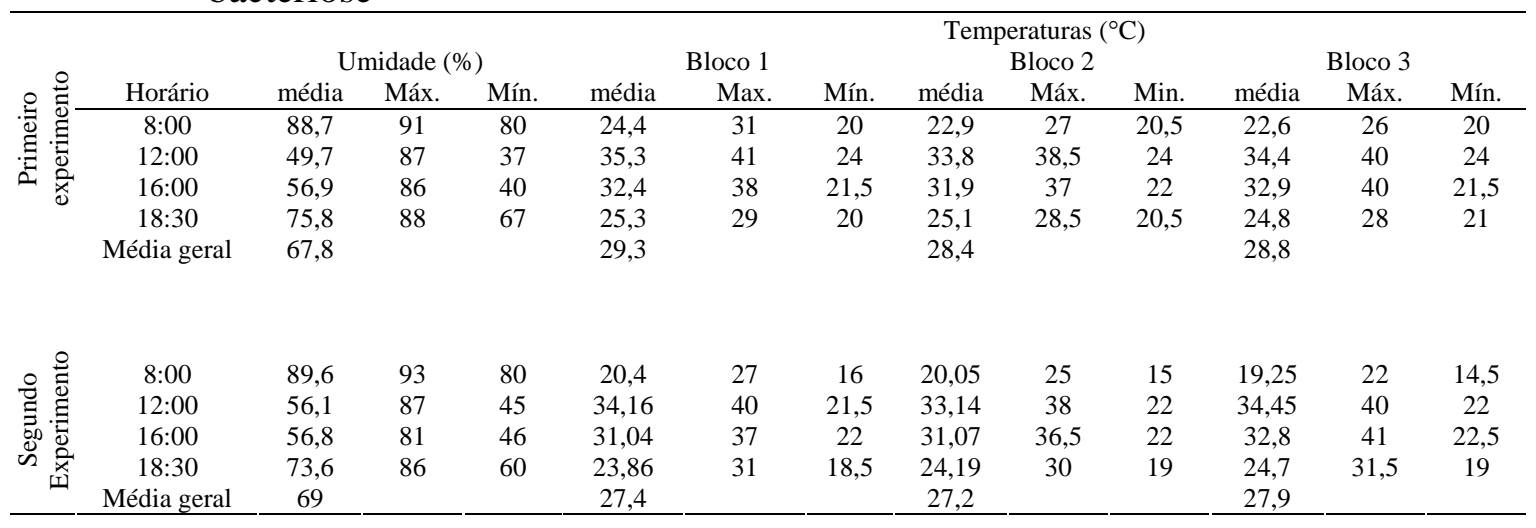


Também, foram obtidos os valores referentes à temperatura ambiente, na proximidade ao local do experimento, ou seja, externamente à área de inoculação (Tabela 3) ${ }^{1}$.

Tabela 3. Valores médios obtidos para temperaturas máxima, média e mínima encontradas durante os dois experimentos, do período de inoculação à data da última mensuração de lesão

\begin{tabular}{cccccc}
\hline \multicolumn{3}{c}{ Primeiro Experimento $\left({ }^{\circ} \mathrm{C}\right)$} & \multicolumn{3}{c}{ Segundo Experimento $\left({ }^{\circ} \mathrm{C}\right)$} \\
\hline Máxima $^{2 /}$ & Média & Mínima $^{2 /}$ & Máxima $^{2 /}$ & Média & Mínima $^{2 /}$ \\
$28,76(32,00 / 22,70)$ & 23,00 & $17,20(19,00 / 15,70)$ & $28,93(32,6 / 21,1)$ & 22,28 & $15,59(18,6 / 9,90)$ \\
\hline${ }^{2 /}$ Legenda: Valor médio (valor máximo/ valor mínimo) & & &
\end{tabular}

Ao se comparar as temperaturas do interior do telado de inoculação com aquelas do lado externo, no período entre a inoculação das plantas até a última tomada dos dados, verifica-se que as temperaturas internas foram, em média, $5,83{ }^{\circ} \mathrm{C}$ e $5,22{ }^{\circ} \mathrm{C}$ superiores às externas, relativamente ao primeiro e segundo experimentos. De acordo com Dias (2000), verifica-se que as condições ambientais observadas neste trabalho foram consideradas adequadas para o desenvolvimento da bacteriose.

\subsection{Inoculação do isolado patogênico}

As inoculações ocorreram nos dias 20/03/2003, para o primeiro experimento, e 18/04/2003, para o segundo experimento. As mensurações tiveram início após ter sido verificado o desenvolvimento de lesões em todos os genótipos. Assim, a primeira mensuração foi realizada somente aos 11 e aos 13 dias após a inoculação para o primeiro e segundo experimentos, respectivamente. Novas mensurações foram realizadas a cada dois dias, fazendo-se um novo contorno ao redor da lesão. Depois de observadas lesões nas proximidades do pecíolo, em alguns genótipos, foi delimitado o último contorno da lesão bacteriana. As últimas avaliações ocorreram nos dias 06/04/2003 e 05/05/2003

\footnotetext{
${ }^{1}$ Fonte: Base de dados do Posto Agrometeorológico (ESALQ - USP).
} 
para o primeiro e segundo experimentos, respectivamente. Portanto, foram realizadas quatro avaliações durante o primeiro experimento e três durante o segundo. Vale relatar que os tecidos necrosados e os cloróticos, observados a partir do corte de inoculação, foram considerados como sintomas da doença.

Essas observações metodológicas estão inseridas neste item da tese, assim como outras, para facilitar a leitura do texto.

\subsubsection{Metodologias para medição de lesões foliares em maracujá-amarelo}

Para avaliação das três metodologias, optou-se pela utilização das mensurações obtidas na última oportunidade, em cada experimento, ou seja, no quarto delineamento do primeiro experimento e no terceiro delineamento do segundo experimento.

Inicialmente, foram digitalizadas as folhas destacadas de cada bloco, separadamente. De modo, concomitante, foram realizados os desenhos das lesões, ao sobrepor as folhas lesionadas com transparências e tirar cópias em papel de forma a possibilitar o recorte da região lesionada e, posteriormente, sua mensuração com base no medidor de área foliar Li-cor (Licor-3100, Nebraska, EUA). Com base nas imagens digitalizadas foi possível fazer as mensurações com o auxílio do programa computacional QUANT e também, as avaliações subjetivas por parte de quatro avaliadores, pelo método Visual.

Com base nos dados das três metodologias foram realizadas análises prévias, para cada experimento de inoculação, sendo constatado que os mesmos não estavam de acordo com as quatro premissas básicas para a realização das análises de variâncias. Através de uma análise de regressão, utilizando o logaritmo do desvio padrão, como variável dependente, e o logaritmo da média experimental, como variável independente, conforme descrito por Montgomery (2001), foi constatada a necessidade de se realizar a transformação logarítmica dos dados. Também, foi necessário o descarte de algumas 
observações, para o primeiro e o segundo experimento, pois com base nas análises de resíduos padronizados, os mesmos estavam sendo discrepantes aos demais apresentados.

Um resumo das análises de variâncias para os dois experimentos encontra-se na Tabela 4.

Tabela 4. Análise da avaliação das três metodologias adotadas para mensuração da severidade da bacteriose do maracujazeiro provocada pela inoculação com Xanthomonas axonopodis pv. passiflorae, nos dois experimentos

\begin{tabular}{|c|c|c|c|c|}
\hline \multirow{2}{*}{ Fonte de Variação } & \multicolumn{2}{|c|}{ Primeiro experimento } & \multicolumn{2}{|c|}{ Segundo experimento } \\
\hline & G.L. & Quadrado Médio & G.L. & Quadrado Médio \\
\hline Bloco & 2 & 0,7885 & 2 & 2,0950 \\
\hline Genótipo & 103 & $0,3634 *$ & 103 & $0,3935 *$ \\
\hline Bloco x Genótipo & 206 & $0,1441^{*}$ & 206 & $0,2099 *$ \\
\hline Parcela & 311 & & 311 & \\
\hline Posição da folha & 2 & $0,4673 *$ & 2 & $0,1615^{\mathrm{ns}}$ \\
\hline Genótipo x Posição da folha & 206 & $0,0478^{\text {ns }}$ & 206 & $0,0459^{\mathrm{ns}}$ \\
\hline Bloco x Posição da folha & 4 & $0,0605^{\mathrm{ns}}$ & 4 & $0,0364^{\mathrm{ns}}$ \\
\hline Bloco x Genótipo x Posição da folha & 399 & $0,0449 *$ & 387 & $0,0413^{*}$ \\
\hline Sub-parcela & 922 & & 910 & \\
\hline Metodologia & 2 & $1,2784^{*}$ & 2 & $7,2457^{*}$ \\
\hline Genótipo x Metodologia & 206 & $0,0022 *$ & 206 & $0,0057^{*}$ \\
\hline Posição da folha x Metodologia & 4 & $0,0027^{\mathrm{ns}}$ & 4 & $0,0004^{\mathrm{ns}}$ \\
\hline Genótipo x Posição da folha x Metodologia & 412 & $0,0012^{\mathrm{ns}}$ & 412 & $0,0017^{\mathrm{ns}}$ \\
\hline Resíduo & 1201 & 0,0013 & 1184 & 0,0027 \\
\hline Total & 2747 & & 2718 & \\
\hline $\mathrm{R}^{2}$ & & 0,98 & & 0,97 \\
\hline $\mathrm{CV}(\%)$ & & 3,07 & & 5,97 \\
\hline
\end{tabular}

*; ns : Significativo e não significativo, ao nível de $5 \%$ de probabilidade, respectivamente. $\mathrm{R}^{2}$ : Coeficiente de determinação do modelo; CV(\%): Coeficiente de variação

Os experimentos produziram alguns resultados semelhantes, permitindo realizar algumas inferências sobre as análises com maior consistência.

De acordo os resultados apresentados na Tabela 4, há diferenças genéticas na população segregante quanto à resistência à bacteriose. $\mathrm{O}$ primeiro experimento demonstrou que a posição das folhas interfere na resposta à agressividade da bactéria enquanto, no segundo, essa diferença não foi detectada.

Para ambos experimentos a interação posição das folhas $\mathrm{x}$ genótipo foi não significativa, indicando que as posições tiveram mesmo comportamento entre si para 
todos os genótipos, isto é, independente da posição da folha inoculada, a classificação dos indivíduos permanece estatisticamente inalterada.

Entretanto, ao considerar a interação genótipo x metodologia, verifica-se que dependendo da metodologia utilizada, há uma classificação (ranking) diferente dos genótipos quanto à resistência à bacteriose. A escolha da metodologia para os próximos estudos deve ser realizada com base na sua confiabilidade, evitando possíveis fontes de erros no processo de mensuração.

Apenas alguns resultados colhidos no segundo experimento foram discordantes. Entretanto, não há como saber se esses resultados discordantes se devem à reutilização das plantas do primeiro experimento, portanto, já com uma pré-inoculação, o que poderia, de certa forma, afetar a resposta de resistência por parte das plantas ou à utilização de um segundo isolado em associação com o “18b”. Também, um outro ponto a considerar refere-se ao fato dessa segunda avaliação ter sido em uma época com temperaturas mais amenas, principalmente durante o período noturno, o que poderia ter prejudicado o desenvolvimento da bacteriose (Tabela 2).

Neste trabalho, a comparação entre as três metodologias foi realizada sem distinguir, à priori, a mais adequada para as análises de mapeamento. Considerando apenas os dados do primeiro experimento, a simples visualização das dispersões das médias de cada indivíduo, obtidas pelas três metodologias, serviram para demonstrar que os resultados são similares (Figura 16), ou seja, independente do método usado, a dispersão dos fenótipos é semelhante na população segregante.

Os gráficos da Figura 16 foram elaborados da seguinte forma: à esquerda estão localizadas as dispersões dos dados para cada par de metodologias e à direita estão os mesmos dados organizados de forma a possibilitar uma melhor visualização das diferenças existentes entre as mesmas. Nos gráficos da direita, a abscissa corresponde aos genótipos ordenados de forma crescente quanto à suscetibilidade à bacteriose, fixando-se uma determinada metodologia. Na ordenada, são apresentados os valores fenotípicos das duas metodologias. 

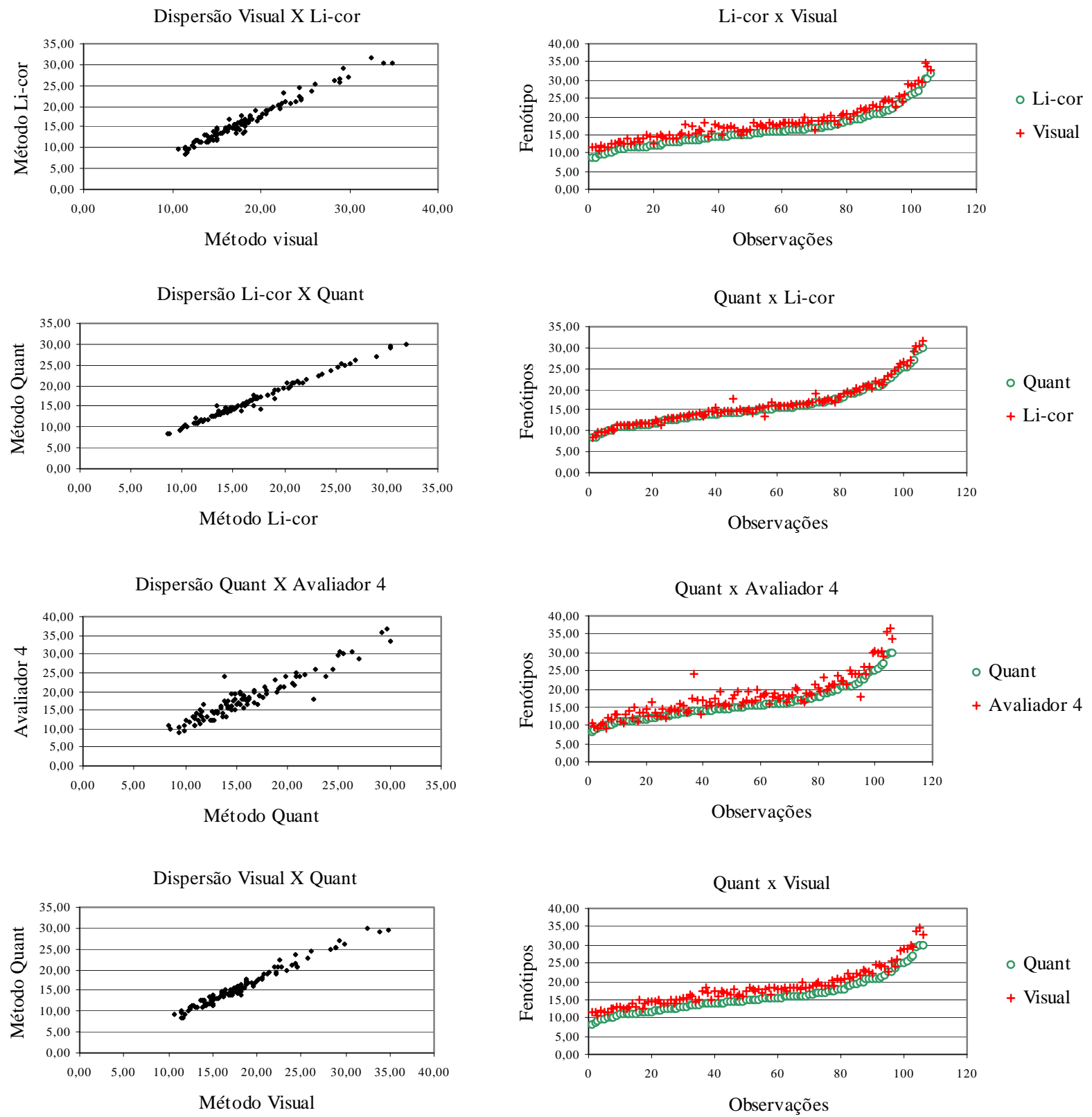

Figura 16 - Comportamento dos dados apresentados utilizando três metodologias para mensurações das lesões após inoculação da população segregante de maracujá-amarelo com Xanthomonas axonopodis pv. passiflorae 
Verifica-se que a distribuição dos dados obtidos pela metodologia Li-cor aproxima-se dos obtidos pelo programa computacional QUANT. Esperava-se que os resultados não fossem muito discrepantes, contudo, foram apresentadas algumas diferenças como, por exemplo, a verificada para o indivíduo 12(9), com 17,67 $\mathrm{cm}^{2}$ de lesão, pelo método Li-cor e de $14,51 \mathrm{~cm}^{2}$, pelo QUANT.

Durante o processo de avaliação pelo método Li-cor, foi possível identificar alguns erros que essa metodologia poderia acarretar. Ao sobrepor a transparência com sua respectiva cópia em papel, algumas discrepâncias apareceram. Ao procurar sobrepor cada lesão, foi verificado que a discrepância poderia ser maior ou menor, dependendo da posição em que se encontrava a lesão na transparência (Figura 17A). De uma forma geral, as linhas pontilhadas demonstram quanto distorcidas ficaram as cópias de seus respectivos originais em transparências (Figura 17B).

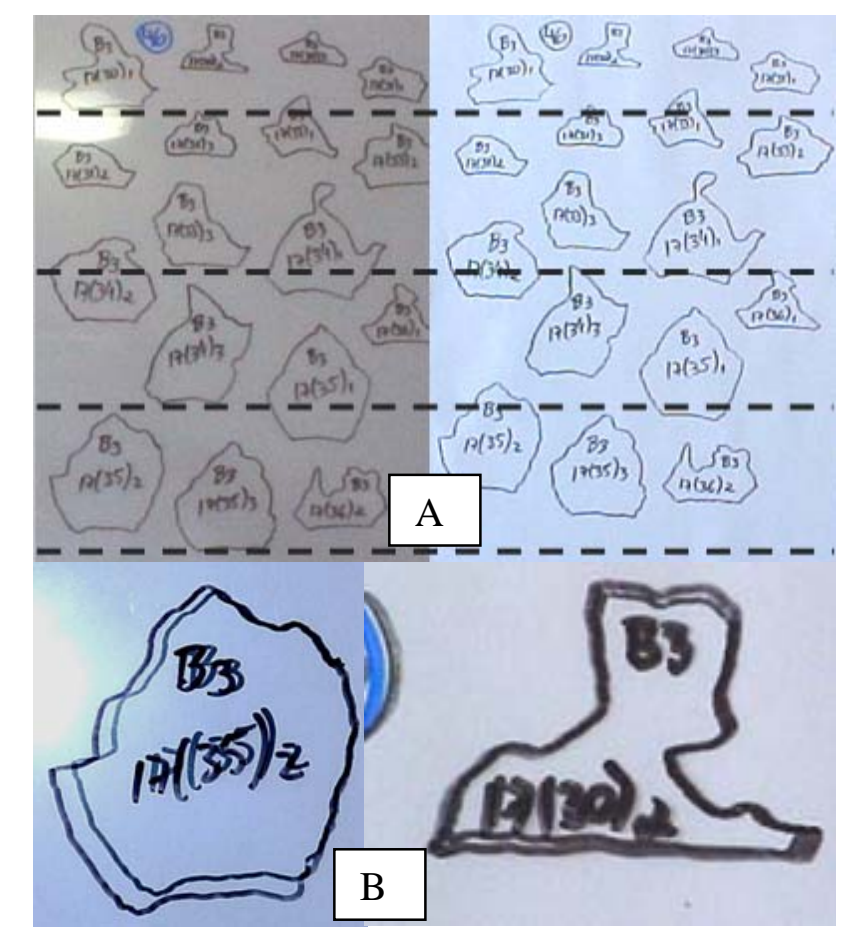

Figura 17 - Discrepâncias causadas pela cópia (A - à direita), podendo ser maiores ou menores em função da posição do desenho na transparência (B) 
Mesmo pelo método Visual, que tem uma característica subjetiva, os resultados apresentaram-se bem semelhantes aos demais. Vale salientar que os dados correspondem à média de quatro observações realizadas por diferentes pessoas, diminuindo, portanto, o problema da subjetividade.

Os resultados da avaliação Visual (Figura 16), mostram que a mensuração realizada por apenas um avaliador possui maiores discrepâncias (gráfico QUANT x Avaliador 4). Como esperado, a média das mensurações de quatro diferentes avaliadores se aproxima dos resultados apresentados pelas outras metodologias, as quais são consideradas mais precisas, pois não dependem da subjetividade durante as avaliações (gráficos QUANT x Visual e Li-cor x Visual). Ao se comparar os dados do programa computacional QUANT e do método Li-cor, com os apresentados pelo método Visual, verifica-se que este último apresenta uma tendência de superestimar os valores das lesões. Este fato também foi relatado por Miranda (2004).

No trabalho realizado por Miranda (2004), o foco das análises era validar uma escala diagramática, de forma a se obter um método de fácil utilização e capaz de fornecer uma rápida estimativa da doença. Para tanto, os dados de severidade, estimados visualmente por avaliadores, com base na escala diagramática, foram comparados com os dados obtidos pelo medidor de área foliar Li-cor, os quais foram considerados como padrão. De acordo com a autora, o uso da escala mostrou-se ser um método rápido, de boa precisão e acurácia. Entretanto, vale ressaltar que as plantas de maracujá-amarelo tinham apenas 30 dias de idade e as folhas inoculadas possuíam um único lóbulo, facilitando, portanto, as mensurações, pois o material foliar, neste estágio de desenvolvimento, apresenta grande homogeneidade no formato.

Por outro lado, como o material usado neste trabalho já se apresentava em estádio mais adiantado de desenvolvimento, com folhas trilobulares, isto dificultou realizar mensurações em porcentagens; além disso, os genótipos já apresentaram diferenças significativas no tamanho das folhas (Tabela 5). 
Tabela 5. Resumo da análise de variância para o tamanho das folhas inoculadas e indicação dos indivíduos com as maiores e menores médias ajustadas $\left(\mathrm{cm}^{2}\right)$ nos dois experimentos

\begin{tabular}{|c|c|c|c|c|}
\hline \multirow{2}{*}{ Fonte de Variação } & \multicolumn{2}{|c|}{ Primeiro experimento } & \multicolumn{2}{|c|}{ Segundo experimento } \\
\hline & G.L. & Quadrado Médio & G.L. & Quadrado Médio \\
\hline Bloco & 2 & 4865,9252 & 2 & 0,01003 \\
\hline Genótipo & 103 & $3053,8463 *$ & 103 & $0,04771^{*}$ \\
\hline Bloco x Genótipo & 206 & $1614,9331 *$ & 206 & $0,02773^{*}$ \\
\hline Posição da folha & 2 & $2195,3104^{*}$ & 2 & $0,04141^{*}$ \\
\hline Genótipo x Posição da folha & 206 & $277,9611^{\mathrm{ns}}$ & 206 & $0,00171^{*}$ \\
\hline Resíduo & 411 & 254,2007 & 393 & 0,00127 \\
\hline Total & 930 & & 912 & \\
\hline $\mathrm{R}^{2}$ & & 0,87 & & 0,96 \\
\hline $\mathrm{CV}(\%)$ & & 13,69 & & 1,67 \\
\hline Maior (Indivíduo/ média) & & $11(1) / 162,51$ & & $17(24) / 188,18$ \\
\hline Menor (Indivíduo/ média) & & $17(39) / 58,09$ & & $17(39) / 59,38$ \\
\hline
\end{tabular}

Foi significativo o efeito de posição das folhas (Tabela 5). Com base nas médias das três repetições, dos dados do primeiro experimento, para 31 genótipos as folhas mais jovens foram as maiores, enquanto para 36 genótipos, as folhas mais velhas foram as maiores. Como exemplo, o genótipo 1(3) apresentou como maior folha a de número 3, ou seja, a mais nova, com média de 140,27 $\mathrm{cm}^{2}$, enquanto para o genótipo 10(5), a maior folha foi a número 1, ou seja, a mais velha, com média de 143,41 cm².

O método Visual demonstrou-se viável, entretanto, há necessidade da mensuração ser realizada por mais avaliadores devido aos tamanhos diferentes e formato trilobular das folhas de maracujá. O método Li-cor, com recortes das lesões em papel, também se mostrou interessante, entretanto, deve ser observado que o processo de fotocópia pode causar algumas discrepâncias entre a área da transparência e a respectiva cópia em papel. Além disso, o desenho da lesão e seu recorte são processos manuais e, portanto, estão passíveis a erros. Vale salientar que essas duas metodologias ainda apresentam uma grande desvantagem, pois, após o processo de mensuração, as folhas são descartadas, impedindo reavaliações e comparações entre sintomas tomados em diferentes experimentos. Portanto, optou-se pela metodologia que tem por base o programa computacional QUANT, pois, além da confiabilidade, ela é a mais prática. 
A distribuição dos dados fenotípicos de cada metodologia foram semelhantes (Figura 18), demonstrando uma distribuição típica de caracteres quantitativos. Verificase, também, que os resultados apresentados pelos genitores foram próximos. Para a construção desses gráficos, os valores fenotípicos de cada genótipo, foram obtidos com base nas médias, considerando as três folhas e as três repetições, dos dados originais, em porcentagem.

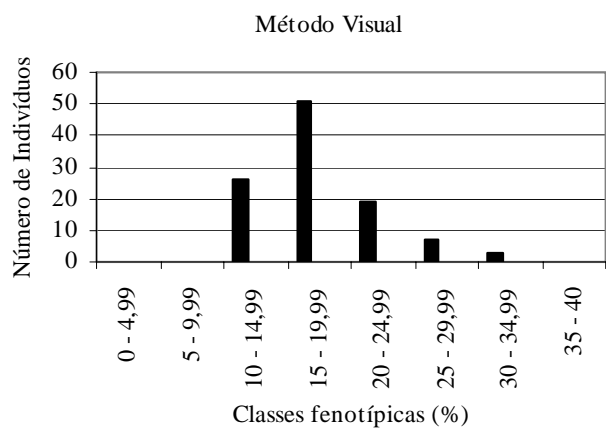

IAPAR-06 $=12,54 \%$ IAPAR-123 = 16,35\%

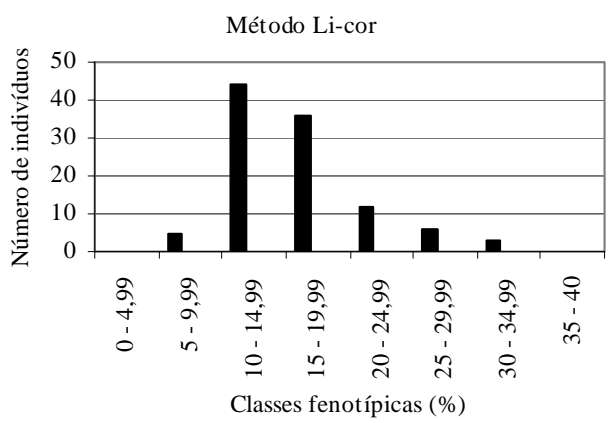

IAPAR-06 $=10,24 \%$ IAPAR-12.3 = 15.11\%

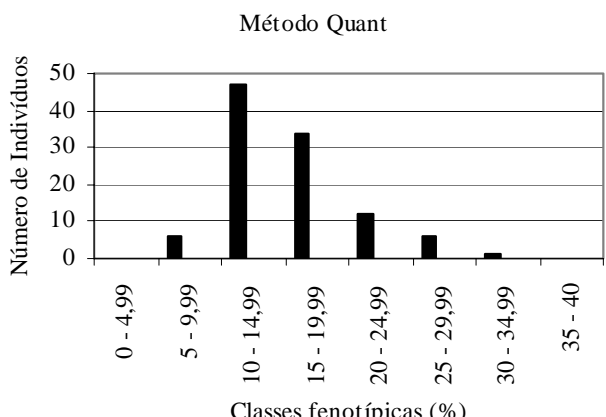

IAPAR-06 $=10,34 \%$ IAPAR-123 = 14,53\%

Figura 18 - Distribuição das médias fenotípicas dos dados obtidos pelas três metodologias de mensuração das lesões e valores apresentados pelos genitores (IAPAR-06 e IAPAR-123) 
Os genitores de uma população de mapeamento devem apresentar suficiente variação tanto para as seqüências de DNA (marcadores genéticos) quanto em nível fenotípico. A variação de DNA é essencial para se detectar os eventos de recombinação. Quanto maior a variação, maior será a facilidade de se encontrar marcadores polimórficos informativos. Na avaliação de Lopes (2003), envolvendo marcadores AFLP, os genitores aqui usados apresentaram 13,28\% (1.355/10.200) de locos polimórficos detectados em testes de combinações de iniciadores.

Quando o objetivo da pesquisa é a busca de genes que controlem uma característica particular, a variação genética entre os genitores é importante. Se os genitores são altamente diferentes fenotipicamente, então haverá uma razoável chance de que também exista variação genética entre os genitores. Por outro lado, a ausência de variação fenotípica entre os genitores não significa que não haja variação genética, pois diferentes conjuntos de genes podem resultar no mesmo fenótipo (Kearsey \& Pooni, 1996; Liu, 1998), o que possivelmente possa explicar o observado neste trabalho.

\subsubsection{Análise do desenvolvimento da bacteriose em maracujá-amarelo}

Os dados usados nas análises do desenvolvimento da bacteriose foram obtidos com base na diferença encontrada entre as lesões formadas no intervalo de dois dias, isto é, procurou-se trabalhar com o tecido clorótico que apareceu no intervalo a cada dois dias. Foi avaliado se o comportamento dos genótipos mensurados em certa data seria o mesmo apresentado em uma outra data.

Os dados da área 1 correspondem àquela obtida com a demarcação aos 11 dias após a inoculação; a área 2 foi obtida pela diferença da área encontrada com o segundo contorno, aos 13 dias, com a área da primeira lesão; a área 3 pela diferença da área da demarcação realizada aos 15 dias com a área obtida aos 13 dias; e, finalmente, a área 4 foi corresponde à diferença entre a área calculada na quarta demarcação, aos 17 dias, e a área da terceira demarcação, isto é, aos 15 dias após a inoculação. Esse artifício foi 
utilizado para avaliar a ocorrência de interação genótipo x data de avaliação, a qual poderia interferir nos resultados de detecção de QRL (Figura 19). O mesmo raciocínio foi utilizado para o segundo experimento.
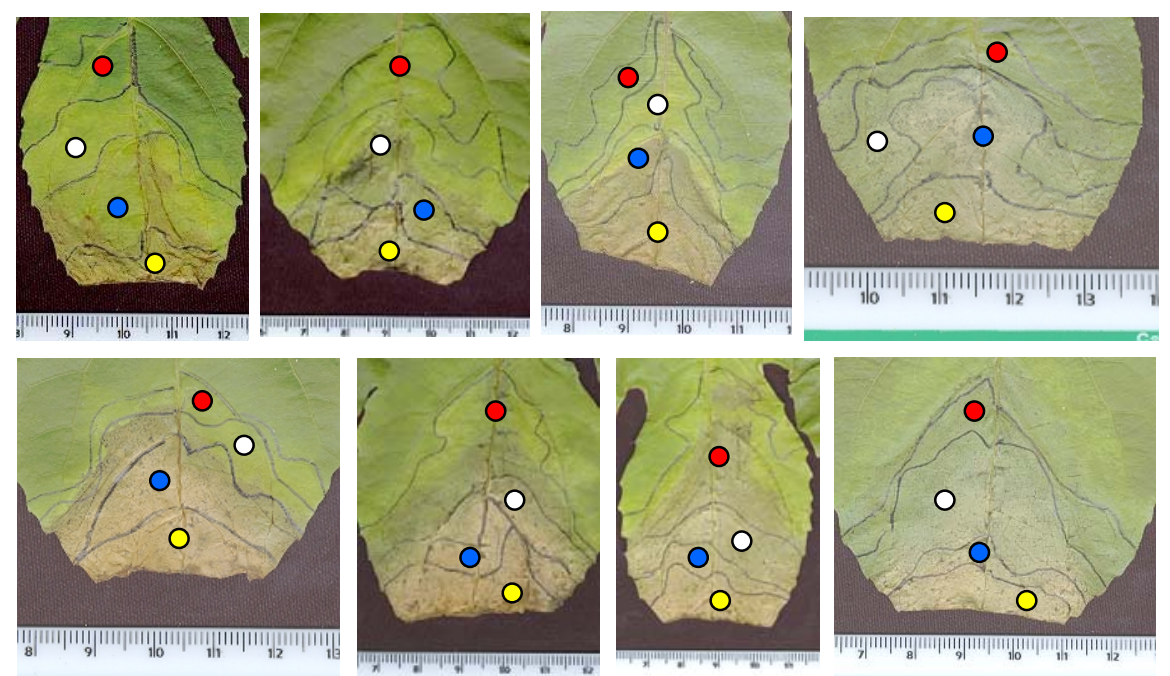

\section{Área 1}

Área 2

Área 3

Área 4

Figura 19 - Exemplo de crescimento desuniforme das lesões conforme mostram os contornos desenhados em cada folha, nas quatro áreas (representadas por cores diferentes) tomadas a cada dois dias

Note que há folhas com lesões que ultrapassam a última demarcação realizada (Figura 19). O processo de digitalização das imagens das folhas, em cada experimento, levou três dias para ser completado. Para não perder a qualidade do material foliar a ser digitalizado, cada bloco do experimento foi trabalhado por dia. Enquanto isso, as folhas dos demais blocos permaneciam nas plantas, dando a oportunidade para um maior avanço das lesões.

Caso os genótipos apresentassem uma mesma taxa de crescimento da lesão no período de dois dias, a possível interação data de avaliação x genótipos não seria detectada. Bastaria realizar somente uma mensuração das lesões, após certo período, pois os genótipos apresentariam o mesmo comportamento entre si, quanto à resistência. O que foi verificado é que os genótipos permitem a colonização com diferentes taxas de 
desenvolvimento com o passar do tempo. Empiricamente foi possível verificar taxas distintas de avanço das lesões nos diferentes genótipos (Figura 20). Isso também foi verificado para o segundo experimento (gráficos não demonstrados).
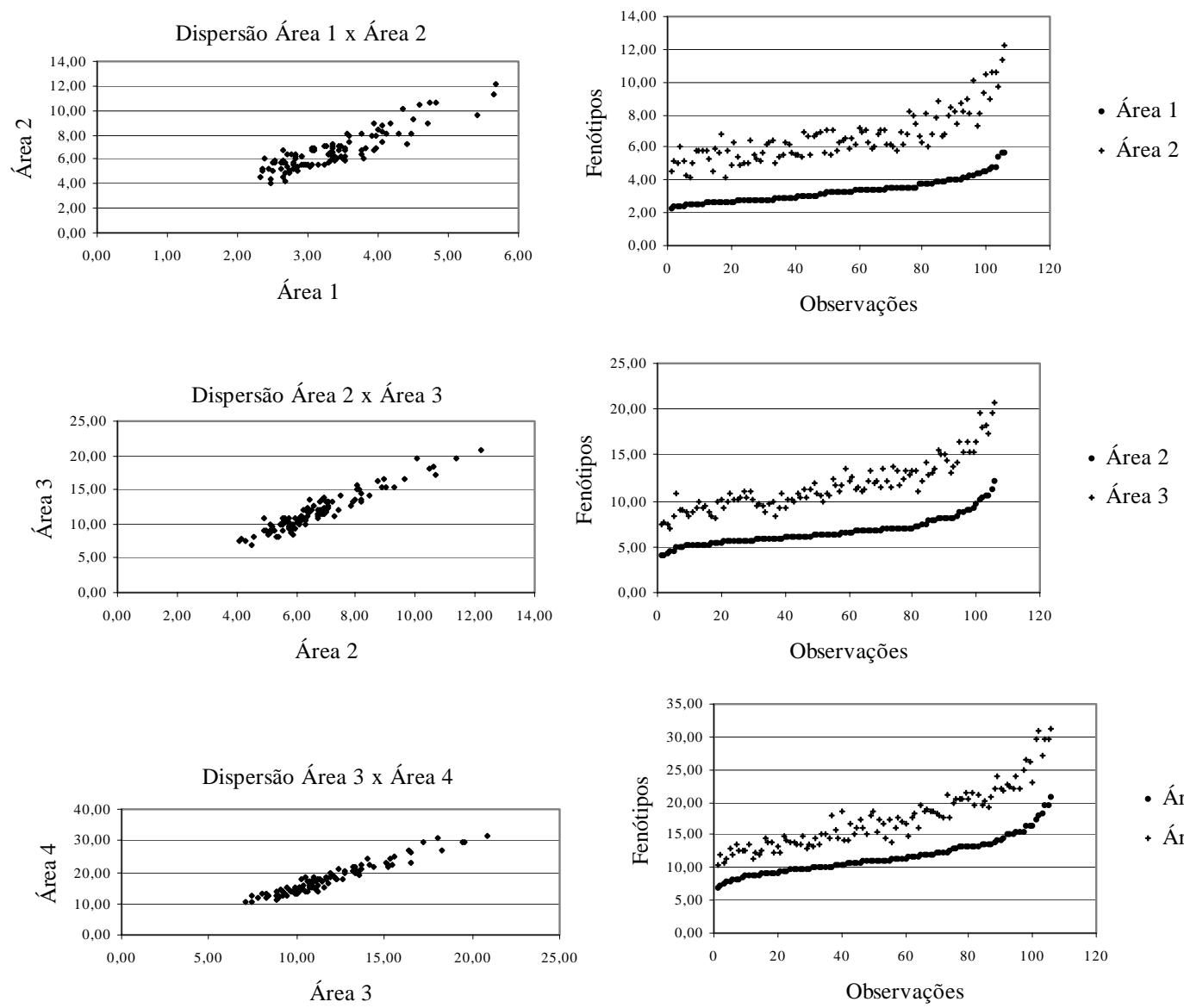

- Área 3

+ Área 4
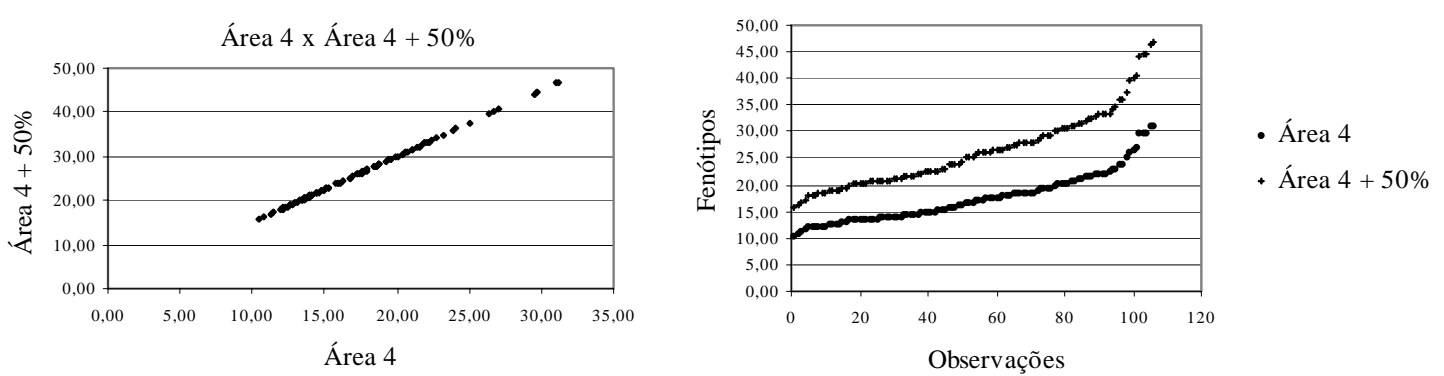

Figura 20 - Comparação entre as dispersões dos dados fenotípicos tomados a cada dois dias 
Verificou-se que existe uma maior disparidade entre os dados da área 1 com a sua subseqüente avaliação (área 2), comparativamente às dispersões entre os dados das áreas $2 \times 3$ e entre $3 \times 4$. Isso pode ser devido aos diferentes tempos de incubação que o isolado bacteriano possa ter apresentado para cada genótipo.

Os gráficos mostrados na Figura 20 mostram uma comparação entre os dados da quarta área e um hipotético conjunto de dados. Esse hipotético conjunto foi formado pelos valores da quarta área adicionando-se 50\% de avanço para a respectiva área, supondo uma progressão uniforme para todos os genótipos. A presença de duas linhas ao invés de uma "nuvem” de pontos, indica como seria o comportamento dos dados caso não houvesse um desenvolvimento diferenciado entre os genótipos, comparativamente aos valores mensurados na oportunidade anterior.

Para análise desses dados, também, foram realizadas análises prévias, para cada experimento, quanto à obediência dos mesmos às quatro premissas básicas da análise de variância. Novamente, foi constatada a necessidade de se realizar a transformação logarítmica dos dados e o descarte de algumas observações, para o primeiro e o segundo experimento (Tabela 6).

Tabela 6. Observações descartadas para garantir que as premissas básicas das análises de variância fossem atendidas ${ }^{1 /}$

\begin{tabular}{cccccccccc}
\hline & \multicolumn{3}{c}{ Primeiro Experimento } & \multicolumn{4}{c}{ Segundo Experimento } \\
Rep & Pos & Área & Trat & Fen & Rep & Pos & Área & Trat & Fen \\
\hline 1 & 2 & 4 & $12(6)$ & 0,34 & 3 & 2 & 1 & $12(9)$ & 8,80 \\
& & & & & 2 & 1 & 3 & $17(3)$ & 10,78 \\
& & & & & 1 & 1 & 3 & $17(36)$ & 1,04 \\
\hline
\end{tabular}

${ }^{1 /}$ Rep = repetição; Pos = posição da folha na planta; Área = respectiva área medida no intervalo de dois dias; Trat = genótipo avaliado e Fen = área lesionada obtida $\left(\mathrm{cm}^{2}\right)$

De acordo com Charnet et al. (1999), uma ou mais observações discrepantes, quando incorporadas em um modelo de regressão, podem vir a prejudicar o ajuste, dando uma falsa idéia da qualidade do modelo. Portanto, quando são detectadas observações discrepantes, deve-se procurar as suas origens. Se a razão da discrepância for devida, por exemplo, a algum erro de digitação, pode-se voltar à planilha de dados 
originais para ser feita a correção. Do contrário, deve-se eliminar essas observações e reajustar o modelo com o restante dos dados. Se os valores discrepantes forem de ocorrência rara, ocasionados, por exemplo, por condições específicas, esse fato deve ser analisado com atenção em cada caso, individualmente. Às vezes, o conhecimento de tais observações pode conduzir ao ajuste para outro modelo. É importante salientar que a eliminação de observações deve ser feita de maneira muito criteriosa, pois além de se estar diminuindo o conjunto de observações, pode-se estar eliminando informações pertinentes ao fenômeno biológico. Essa é uma das vantagens em se trabalhar com o QUANT.

Um resumo dos resultados das análises de variâncias, dos dois experimentos, encontra-se na Tabela 7.

Tabela 7. Análise de variância dos dados de severidade da bacteriose do maracujazeiro provocada pela inoculação com Xanthomonas axonopodis pv. passiflorae, em dois experimentos

\begin{tabular}{|c|c|c|c|c|}
\hline \multirow{2}{*}{ Fonte de Variação } & \multicolumn{2}{|c|}{ Primeiro experimento } & \multicolumn{2}{|c|}{ Segundo experimento } \\
\hline & G.L. & Quadrado Médio & G.L. & Quadrado Médio \\
\hline Bloco & 2 & 0,9004 & 2 & 2,4525 \\
\hline Genótipo & 103 & $0,2800 *$ & 103 & $0,2648 *$ \\
\hline Bloco x Genótipo & 206 & $0,1245^{*}$ & 206 & $0,1189 *$ \\
\hline Parcela & 311 & & 311 & \\
\hline Posição da folha & 2 & $0,3857^{*}$ & 2 & $0,2469 *$ \\
\hline Genótipo x Posição da folha & 206 & $0,0341 *$ & 206 & $0,0329^{\mathrm{ns}}$ \\
\hline Bloco x Posição da folha & 4 & $0,0458^{\mathrm{ns}}$ & 4 & $0,0286^{\mathrm{ns}}$ \\
\hline Bloco x Genótipo x Posição da folha & 407 & $0,0285^{*}$ & 390 & $0,0294 *$ \\
\hline Sub-parcela & 930 & & 913 & \\
\hline Área & 3 & $7,5526 *$ & 2 & $5,2697 *$ \\
\hline Genótipo x Área & 309 & $0,0308 *$ & 206 & 0,0299* \\
\hline Posição da folha x Área & 6 & $0,0413 *$ & 4 & $0,0532 *$ \\
\hline Genótipo x Posição da folha x Área & 618 & $0,0136^{\mathrm{ns}}$ & 412 & $0,0126^{\mathrm{ns}}$ \\
\hline Resíduo & 1840 & 0,0191 & 1200 & 0,0150 \\
\hline Total & 3706 & & 2737 & \\
\hline $\mathrm{R}^{2}$ & & 0,77 & & 0,84 \\
\hline $\mathrm{CV}(\%)$ & & 20,16 & & 21,51 \\
\hline
\end{tabular}

*; ns : Significativo e não significativo, ao nível de $5 \%$ de probabilidade, respectivamente. $\mathrm{R}^{2}$ : Coeficiente de determinação do modelo; CV(\%): Coeficiente de variação

Resultados semelhantes foram obtidos para ambos os experimentos, o que permite realizar inferências com maior consistência. Considerando que esta é uma população segregante para várias características (Carneiro et al., 2002), verificou-se 
haver, também, diferenças genéticas entre os indivíduos, quanto à resistência à bacteriose. Para ambos os experimentos foi possível constatar que a posição das folhas interfere na resposta à agressividade da bactéria. Esse resultado pode ser explicado pelo fato das folhas terem apresentado, em média, uma diferença de idade de 5,3 dias, o que corresponde a uma diferença média de 10,6 dias entre a folha inferior e a superior.

O primeiro experimento apontou haver interação significativa entre posição das folhas x genótipo (Tabela 7), ou seja, para cada posição da folha, há uma classificação distinta dos genótipos quanto à resistência a bacteriose. O segundo experimento revelou que essa interação foi não significativa, indicando que as posições das folhas tiveram mesmo comportamento entre si em todos os genótipos.

A ausência de interação entre posição das folhas e genótipos (segundo experimento) possibilita direcionar futuros trabalhos de inoculação (Tabela 7). Esse mesmo resultado foi obtido ao se retirar o efeito de metodologias de avaliação, nos dois experimentos (Tabela 4). O principal interesse de uma inoculação está na diferenciação, dos indivíduos quanto à resistência e, de acordo com os resultados obtidos neste trabalho, a idade (ou posição) das folhas interfere no grau de resposta, mas não interfere na classificação entre os genótipos.

Recomenda-se realizar inoculações com diferentes isolados e até mesmo com um conjunto deles, em uma dada época de inoculação e numa mesma planta. Poderiam ser realizados estudos de interação entre esses isolados, comparativamente às plantas inoculadas com um único isolado, e sobre possíveis alterações nas respostas de defesa, como aumento da senescência das folhas e até mesmo a morte das plantas. Como não há dificuldade para a obtenção de clones das plantas de maracujá, esses estudos podem ser realizados com relativa facilidade. Considerando um local (telado) maior para a inoculação, deveria ser utilizado um número maior de plantas por parcela.

Em ambos os experimentos, a interação área $\mathrm{x}$ genótipo foi significativa, indicando que a data de avaliação, considerando um mesmo experimento de inoculação, pode levar a diferentes classificações de genótipos quanto à resistência a bacteriose. Esse resultado pode ser muito importante dentro um programa de melhoramento, pois indica 
claramente que não há uma data fixa, a partir da inoculação, para se realizar a mensuração, mas que a avaliação da bacteriose não deve ser realizada em uma só oportunidade. Vale salientar que para generalizar esse tipo de resultado, é necessário um número maior de experimentos, em diferentes locais e, até mesmo, avaliar plantas cultivadas no campo.

A significância da interação data de avaliação x posição da folha, em ambos experimentos, demonstra que as folhas, mesmo com idades diferentes, apresentaram avanço de lesões de forma aleatória, ou seja, a cada dois dias, as lesões apresentaram avanços diferenciados para cada folha. Biologicamente, fica difícil explicar o motivo pelo qual a lesão avança mais rapidamente numa primeira avaliação nas folhas mais novas, numa segunda avaliação nas folhas mais velhas e em uma próxima avaliação, novamente, há um maior crescimento em folhas mais novas. Embora esse resultado tenha sido encontrado nos dois experimentos, novos estudos devem ser realizados para se fazer inferências a respeito.

Em resumo, os principais resultados obtidos indicaram que: a) existe variabilidade fenotípica para resistência à bacteriose possibilitando, portanto, a realização das análises de QRL; b) de acordo com a data de avaliação, os genótipos diferem quanto ao nível de resistência; c) é possível a realização das análises de QRL com os dados obtidos nas diferentes datas; d) o efeito significativo da idade das folhas deve ser considerado nas análises de QRL.

Os dados fenotípicos utilizados para as análises de QRL foram as médias ajustadas das áreas, considerando cada data de avaliação em separado. Foram calculadas as médias das três folhas de cada planta, considerando as áreas obtidas a partir do ponto de inoculação, mensuradas nas oportunidades determinadas. As análises para obtenção das médias ajustadas foram com base no delineamento em blocos com parcelas subdivididas, onde cada planta (genótipo) correspondeu a uma parcela e as posições das folhas, as subparcelas (Tabelas 8 e 9). 
Tabela 8. Resumo das análises de variância considerando as diferentes datas de avaliação do primeiro experimento, com as respectivas áreas de lesão $\left(\mathrm{cm}^{2}\right)$ obtidas em cada oportunidade ${ }^{1 /}$

\begin{tabular}{|c|c|c|c|c|c|c|c|c|}
\hline \multirow{2}{*}{ Fonte de Variação } & \multicolumn{2}{|r|}{ Data 1} & \multicolumn{2}{|c|}{ Data 2} & \multicolumn{2}{|r|}{ Data 3} & \multicolumn{2}{|r|}{ Data 4} \\
\hline & gl & $\mathrm{QM}$ & gl & $\mathrm{QM}$ & gl & $\mathrm{QM}$ & gl & $\mathrm{QM}$ \\
\hline Bloco & 2 & 0,4083 & 2 & 1,0491 & 2 & 0,6907 & 2 & 0,2754 \\
\hline Genótipo & 103 & $0,0431 *$ & 103 & $0,0647^{*}$ & 103 & $0,0902 *$ & 103 & $0,1201^{*}$ \\
\hline Bloco x Genótipo & 206 & $0,0283^{*}$ & 206 & $0,0365^{*}$ & 206 & $0,0447^{*}$ & 206 & $0,0575^{*}$ \\
\hline Posição & 2 & $0,2166^{*}$ & 2 & $0,1213^{*}$ & 2 & $0,1324^{*}$ & 2 & $0,0911 *$ \\
\hline Posição x Genótipo & 206 & $0,0101^{\text {ns }}$ & 206 & $0,0101 *$ & 206 & $0,0145^{*}$ & 206 & $0,0148 *$ \\
\hline Resíduo & 411 & 0,0087 & 405 & 0,0082 & 402 & 0,0107 & 400 & 0,0112 \\
\hline $\mathrm{R}^{2}$ & & 0,79 & & 0,85 & & 0,84 & & 0,86 \\
\hline CV(\%) & & 15,08 & & 10,56 & & 9,94 & & 8,75 \\
\hline $\mathrm{h}^{2}(\%)$ & & 29,22 & & 37,60 & & 41,87 & & 47,05 \\
\hline
\end{tabular}

de $5 \%$ de probabilidade, respectivamente; $\mathrm{R}^{2}$ : Coeficiente de determinação; CV(\%):

Coeficiente de variação do modelo; $h^{2}$ : herdabilidade no sentido amplo

Tabela 9. Resumo das análises de variância considerando as diferentes datas de avaliação do segundo experimento, com as respectivas áreas de lesão $\left(\mathrm{cm}^{2}\right)$ obtidas em cada oportunidade ${ }^{1 /}$

\begin{tabular}{|c|c|c|c|c|c|c|}
\hline \multirow{2}{*}{ Fonte de Variação } & \multicolumn{2}{|r|}{ Data 1} & \multicolumn{2}{|c|}{ Data 2} & \multicolumn{2}{|r|}{ Data 3} \\
\hline & gl & $\mathrm{QM}$ & gl & $\mathrm{QM}$ & gl & $\mathrm{QM}$ \\
\hline Bloco & 2 & 0,9009 & 2 & 1,0632 & 2 & 1,2505 \\
\hline Genótipo & 103 & $0,0820 *$ & 103 & $0,1122 *$ & 103 & $0,1359 *$ \\
\hline Bloco x Genótipo & 206 & $0,0422 *$ & 206 & $0,0556 *$ & 206 & $0,0654 *$ \\
\hline Posição & 2 & $0,0251^{\mathrm{ns}}$ & 2 & $0,0511^{*}$ & 2 & $0,1391 *$ \\
\hline Posição x Genótipo & 206 & $0,0111^{\mathrm{ns}}$ & 206 & $0,0165^{\mathrm{ns}}$ & 206 & $0,0185^{\mathrm{ns}}$ \\
\hline Resíduo & 393 & 0,0109 & 394 & 0,0147 & 393 & 0,0176 \\
\hline $\mathrm{R}^{2}$ & & 0,83 & & 0,83 & & 0,83 \\
\hline CV(\%) & & 19,78 & & 16,01 & & 13,63 \\
\hline $\mathrm{h}^{2}$ & & 54,46 & & 52,11 & & 53,90 \\
\hline
\end{tabular}

${ }^{1 /} * \mathrm{e}^{\text {ns }}$ : Significativo e não significativo estatisticamente ao nível de 5\% de probabilidade; R ${ }^{2}$ : Coeficiente de determinação; CV(\%): Coeficiente de variação do modelo; $\mathrm{h}^{2}$ : herdabilidade no sentido amplo 
Ao analisar as áreas obtidas em cada data, individualmente, ou seja, considerando blocos casualizados com parcelas subdivididas, os dados demonstram um fato interessante para um programa de melhoramento.

Como era de se esperar, considerando o primeiro experimento, quanto maior o período entre a data de inoculação e a data de mensuração das lesões, mais facilmente pode-se distinguir genótipos quanto à resistência à bacteriose. Isso pode ser observado pelo crescente valor de herdabilidade no decorrer do tempo, ou seja, a variabilidade genética quanto à resistência tende a ser mais pronunciada, quanto maior for o período após a inoculação. A interação posição das folhas x genótipo também passa a ser significativa quanto maior o tempo após a inoculação.

O segundo experimento conduziu a estimativas de herdabilidade semelhantes para cada data de avaliação; a interação entre posição das folhas x genótipos foi não significativa. Novos estudos sobre essa interação devem ser realizados para permitir inferências mais seguras.

Para verificar o efeito da posição nas análises de QRL, os dados fenotípicos obtidos a cada dois dias foram utilizados para a obtenção das médias ajustadas de forma análoga à utilizada para o estudo do efeito data de mensuração. As análises foram realizadas com base no delineamento em blocos, com parcelas subdivididas, sendo cada planta (genótipo) correspondente a uma parcela e as datas de mensuração, as subparcelas (Tabelas 10 e 11).

Com base nas análises das Tabelas 8, 9, 10 e 11 foram obtidas as médias ajustadas as quais foram utilizadas nos procedimentos de mapeamento de QRL (ver item 4.4). 
Tabela 10. Resumo das análises de variância do primeiro experimento considerando as três posições das folhas, com as respectivas áreas de lesão $\left(\mathrm{cm}^{2}\right)$ obtidas em intervalos de dois dias ${ }^{1 /}$

\begin{tabular}{|c|c|c|c|c|c|c|}
\hline \multirow{2}{*}{ Fonte de Variação } & \multicolumn{2}{|c|}{ Posição 1} & \multicolumn{2}{|c|}{ Posição 2} & \multicolumn{2}{|c|}{ Posição 3} \\
\hline & gl & $\mathrm{QM}$ & gl & $\mathrm{QM}$ & $\mathrm{gl}$ & QM \\
\hline Bloco & 2 & 0,261956 & 2 & 0,246977 & 2 & 0,435758 \\
\hline Genótipo & 103 & $0,117764 *$ & 103 & $0,105384 *$ & 103 & $0,126311 *$ \\
\hline Bloco x Genótipo & 203 & $0,054756 *$ & 204 & $0,051418 *$ & 206 & $0,076524 *$ \\
\hline Área & 3 & $2,094469 *$ & 3 & $3,266050 *$ & 3 & $2,41528 *$ \\
\hline Área x Genótipo & 309 & $0,019686^{\mathrm{ns}}$ & 309 & $0,022031^{\mathrm{ns}}$ & 309 & $0,017227^{\mathrm{ns}}$ \\
\hline Resíduo & 605 & 0,018325 & 612 & 0,0191063 & 618 & 0,018379 \\
\hline $\mathrm{R}^{2}$ & & 0,77 & & 0,77 & & 0,79 \\
\hline $\mathrm{CV}(\%)$ & & 20,18 & & 20,12 & & 19,29 \\
\hline
\end{tabular}

Coeficiente de variação do modelo

Tabela 11. Resumo das análises de variância do segundo experimento considerando as três posições de avaliação das folhas, com as respectivas áreas de lesão $\left(\mathrm{cm}^{2}\right)$ obtidas em intervalos de dois dias ${ }^{1 /}$

\begin{tabular}{|c|c|c|c|c|c|c|}
\hline \multirow{2}{*}{ Fonte de Variação } & \multicolumn{2}{|c|}{ Posição 1} & \multicolumn{2}{|c|}{ Posição 2} & \multicolumn{2}{|c|}{ Posição 3} \\
\hline & gl & $\mathrm{QM}$ & gl & $\mathrm{QM}$ & gl & $\mathrm{QM}$ \\
\hline Bloco & 2 & 0,823684 & 2 & 1,1024584 & 2 & 0,59148 \\
\hline Genótipo & 103 & $0,139761 *$ & 103 & $0,096587^{*}$ & 103 & $0,09640^{*}$ \\
\hline Bloco x Genótipo & 194 & $0,057146 *$ & 202 & $0,056741 *$ & 200 & $0,06715^{*}$ \\
\hline Área & 2 & $1,243604 *$ & 2 & $1,756401^{*}$ & 2 & $2,39989 *$ \\
\hline Área x Genótipo & 206 & $0,0179999^{\mathrm{ns}}$ & 206 & $0,018696^{*}$ & 206 & $0,01878 *$ \\
\hline Resíduo & 389 & 0,014996 & 407 & 0,014812 & 404 & 0,015279 \\
\hline $\mathrm{R}^{2}$ & & 0,85 & & 0,84 & & 0,84 \\
\hline $\mathrm{CV}(\%)$ & & 21,82 & & 21,77 & & 20,97 \\
\hline
\end{tabular}




\subsubsection{Análise conjunta das avaliações realizadas com o isolado “ $18 \mathrm{~b}$ ”}

Os dados obtidos neste trabalho e aqueles obtidos por Lopes (2003) foram primeiramente analisados de forma a verificar a possibilidade de se realizar uma análise conjunta. Vale salientar que o experimento 1 e aquele realizado por Lopes (2003) tiveram 69 indivíduos em comum.

Como os dados fenotípicos de cada indivíduo obtidos por Lopes (2003) eram referentes à média das três folhas de cada planta, foi necessário obter, para cada data de avaliação, a média das três folhas, dentro de cada repetição, para compor os valores de cada parcela. Desconsiderando o efeito de posição das folhas, foi possível fazer com que o presente experimento ficasse no mesmo delineamento estatístico utilizado por Lopes (2003), ou seja, em blocos casualizados.

Foram realizadas análises prévias dos dados, para cada época de avaliação, sendo constatado que os mesmos não estavam de acordo com as premissas básicas para proceder às análises de variância. Também, foi verificada a necessidade de se realizar a transformação logarítmica dos dados.

Os quadrados médios obtidos de cada análise, considerando somente os indivíduos em comum, nas duas avaliações com o isolado "18b”, foram comparados de forma a indicar qual das datas de avaliação seriam utilizadas na análise conjunta (Tabela 12); nesta tabela encontram-se, também, os valores máximos, médios e mínimos das áreas $\left(\mathrm{cm}^{2}\right)$ mensuradas em cada oportunidade.

De acordo com o critério indicado por Gomes (1990), os valores de cada respectiva data de avaliação, poderiam ser utilizados na análise conjunta com os dados obtidos por Lopes (2003). Entretanto, de acordo com o critério indicado por Ferreira (2000), somente os dados das datas 2 (área 2) e 3 (área 3) poderiam ser utilizados. Com o intuito de averiguação, optou-se pela realização das quatro análises conjuntas, ou seja, utilizando os dados obtidos por Lopes (2003) e os dados oriundos de cada data de avaliação (Tabela 13). 
Tabela 12. Resumo das análises de variância dos dados obtidos por Lopes (2003) e os obtidos nas quatro datas de avaliação do primeiro experimento, considerando apenas os 69 indivíduos da progênie $\mathrm{F}_{1}$ comuns às duas teses. Embaixo estão os valores ajustados máximos, médios e mínimos das áreas das lesões $\left(\mathrm{cm}^{2}\right)$ e o respectivo indivíduo ${ }^{1 /}$

\begin{tabular}{|c|c|c|c|c|c|c|c|c|c|c|}
\hline \multirow{2}{*}{$\begin{array}{l}\text { Fonte de } \\
\text { Variação }\end{array}$} & \multicolumn{2}{|r|}{ Lopes (2003) } & \multicolumn{2}{|r|}{ Data 1} & \multicolumn{2}{|r|}{ Data 2} & \multicolumn{2}{|r|}{ Data 3} & \multicolumn{2}{|r|}{ Data 4} \\
\hline & $\mathrm{gl}$ & QM & $\mathrm{Gl}$ & $\mathrm{QM}$ & gl & $\mathrm{QM}$ & $\mathrm{gl}$ & $\mathrm{QM}$ & $\mathrm{gl}$ & $\mathrm{QM}$ \\
\hline Bloco & 2 & 0,0149 & 2 & 0,0855 & 2 & 0,2045 & 2 & 0,1419 & 2 & 0,0776 \\
\hline Genótipo & 68 & $0,0512 *$ & 68 & 0,0139* & 68 & $0,0257 *$ & 68 & 0,0396* & 68 & $0,0435^{*}$ \\
\hline Resíduo & 99 & 0,0091 & 136 & 0,0097 & 135 & 0,0109 & 135 & 0,0139 & 136 & 0,0173 \\
\hline $\mathrm{CV}(\%)$ & & 9,04 & & 15,82 & & 12,12 & & 11,32 & & 10,78 \\
\hline Máximo & & III(11)/ 24,70 & & $17(43) / 6,54$ & & $17(43) / 13,20$ & & $17(43) / 20,69$ & & $3(6) / 30,97$ \\
\hline Média & & 12,26 & & 4,24 & & 7,46 & & 11,38 & & 17,27 \\
\hline Mínimo & & $\mathrm{XV}(7) / 4,73$ & & III(7)/ 3,24 & & $17(39) / 3,16$ & & $17(39) / 3,27$ & & $17(22) / 9,92$ \\
\hline
\end{tabular}

1/* : Significativo estatisticamente ao nível de 5\% de probabilidade; CV(\%): Coeficiente de variação

Tabela 13. Resumo das análises de variância conjunta considerando as duas épocas de avaliação: dados obtidos por Lopes (2003) e nas diferentes datas de avaliação do primeiro experimento ${ }^{1 /}$

\begin{tabular}{|c|c|c|c|c|c|c|c|c|}
\hline \multirow{2}{*}{ Fonte de Variação } & \multicolumn{2}{|c|}{ Lopes (2003) e Data 1} & \multicolumn{2}{|c|}{ Lopes (2003) e Data 2} & \multicolumn{2}{|c|}{ Lopes (2003) e Data 3} & \multicolumn{2}{|c|}{ Lopes (2003) e Data 4} \\
\hline & gl & $\mathrm{QM}$ & gl & $\mathrm{QM}$ & gl & QM & Gl & $\mathrm{QM}$ \\
\hline Éроса & 1 & $20,7193^{*}$ & 1 & $6,3154 *$ & 1 & $0,0343^{\mathrm{ns}}$ & 1 & $2,2965 *$ \\
\hline Bloco/ época & 4 & $0,0393 *$ & 4 & $0,1312^{*}$ & 4 & $0,0682 *$ & 4 & $0,0439 *$ \\
\hline Genótipo & 68 & 0,0316* & 68 & $0,0466 *$ & 68 & $0,0500^{*}$ & 68 & $0,0550 *$ \\
\hline Época x Genótipo & 68 & $0,0304^{*}$ & 68 & $0,0440 *$ & 68 & $0,0452 *$ & 68 & $0,0422 *$ \\
\hline Resíduo & 234 & 0,0082 & 233 & 0,0120 & 233 & 0,0111 & 234 & 0,0130 \\
\hline CV(\%) & & 10,81 & & 11,99 & & 10,03 & & 9,95 \\
\hline $\mathrm{R}^{2}$ & & 0,93 & & 0,82 & & 0,72 & & 0,75 \\
\hline
\end{tabular}

${ }^{1 / *},{ }^{\text {ns }}$ : Significativo e não significativo estatisticamente, ao nível de 5\% de probabilidade, respectivamente; CV(\%): Coeficiente de variação; $\mathrm{R}^{2}$ :

Coeficiente de determinação 
As análises demonstraram a existência de interação significativa entre genótipo e época de avaliação. Considerando que os 69 indivíduos avaliados e o isolado bacteriano foram os mesmos, essa interação demonstra um pronunciado efeito ambiental no desenvolvimento da bacteriose.

Verifica-se que, praticamente, não existe correlação entre o comportamento dos dados nas duas épocas de avaliação (Tabela 14).

Tabela 14. Correlações entre os dados obtidos por Lopes (2003) e os dados obtidos nas quatro oportunidades de avaliação para um mesmo experimento. Acima da diagonal estão as correlações de Pearson. Abaixo da diagonal estão as correlações de Spearman

\begin{tabular}{cccccc}
\hline & Lopes (2003) & Data 1 & Data 2 & Data 3 & Data 4 \\
\hline Lopes (2003) & & $0,0493^{\text {ns }}$ & $0,0827^{\text {ns }}$ & $0,1076^{\text {ns }}$ & $0,1457^{\text {ns }}$ \\
Data 1 & $-0,0236^{\text {ns }}$ & & $0,8997^{*}$ & $0,8511^{*}$ & $0,7989^{*}$ \\
Data 2 & $-0,0154^{\text {ns }}$ & $0,8670^{*}$ & & $0,9480^{*}$ & $0,9105^{*}$ \\
Data 3 & $0,0216^{\text {ns }}$ & $0,8271^{*}$ & $0,9325^{*}$ & & $0,9659^{*}$ \\
Data 4 & $0,0826^{\text {ns }}$ & $0,7674^{*}$ & $0,8693^{*}$ & $0,9552^{*}$ & \\
\hline
\end{tabular}

${ }^{1 / *}{ }^{\text {ns }}$ : Significativo e não significativo, ao nível de $5 \%$ de probabilidade, respectivamente

As correlações significativas demonstram apenas que os genótipos que apresentaram grandes áreas lesionadas em uma determinada data, também apresentaram grandes áreas de lesão em uma nova data de avaliação. Verifica-se que as correlações, entre os dados obtidos neste trabalho, tendem a reduzir com o passar do tempo, ilustrando a interação observada entre data de mensuração x genótipo, discutida anteriormente.

A análise visual da distribuição dos dados, com o auxílio de gráficos, também é útil para uma melhor visualização do efeito ambiental (Figura 21). 

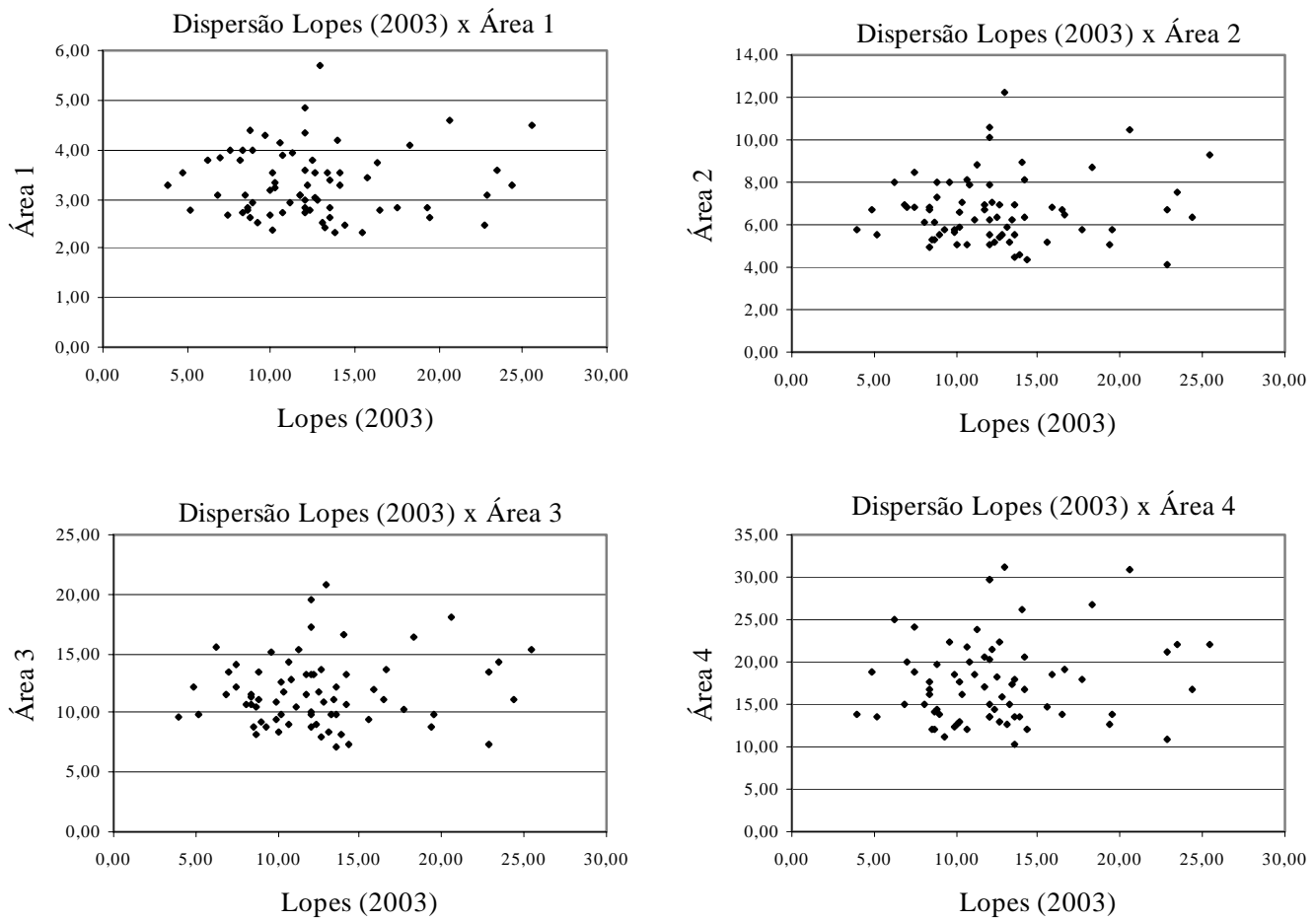

Figura 21 - Dispersão dos dados obtidos por Lopes (2003) e neste estudo, em diferentes datas de avaliação

A existência de interação significativa entre genótipos e época de avaliação (Tabela 13) prejudicaria a análise de QRL, pois seriam utilizadas médias ajustadas, que estariam viesadas devido ao efeito ambiental. Estas médias poderiam acarretar em um mapeamento equivocado dos QRL, indicando que o mapeamento deva ser realizado para cada experimento, individualmente.

\subsection{Genotipagem molecular dos indivíduos $F_{1}$}

Os indivíduos apresentados na Tabela 1, codificados sem os asteriscos, foram caracterizados molecularmente com as mesmas combinações de iniciadores utilizadas por Lopes (2003), para a construção do primeiro mapa genético do maracujazeiro com base em AFLP. 
A Figura 22 demonstra parte da imagem de um gel de AFLP corado com nitrato de prata: à esquerda do marcador de peso molecular (Ladder 100 pb - Invitrogen) estão os genitores IAPAR-06 e IAPAR-123 (canaletas 44 e 45, contadas a partir da esquerda), nas outras canaletas estão os indivíduos da população segregante.

As reações para genotipagem dos novos indivíduos utilizados neste trabalho foram aplicadas ao gel juntamente com algumas amostras das reações realizadas por Lopes (2003), que estavam armazenadas sob $-20^{\circ} \mathrm{C}$ (primeiras oito canaletas, contadas a partir da esquerda). Confirma-se a repetibilidade dessa técnica molecular, garantindo maior confiabilidade nas demais etapas deste trabalho. 
Indivíduos $\mathrm{F}_{1}$

obtidos por

Lopes (2003)

Novos indivíduos $\mathrm{F}_{1}$

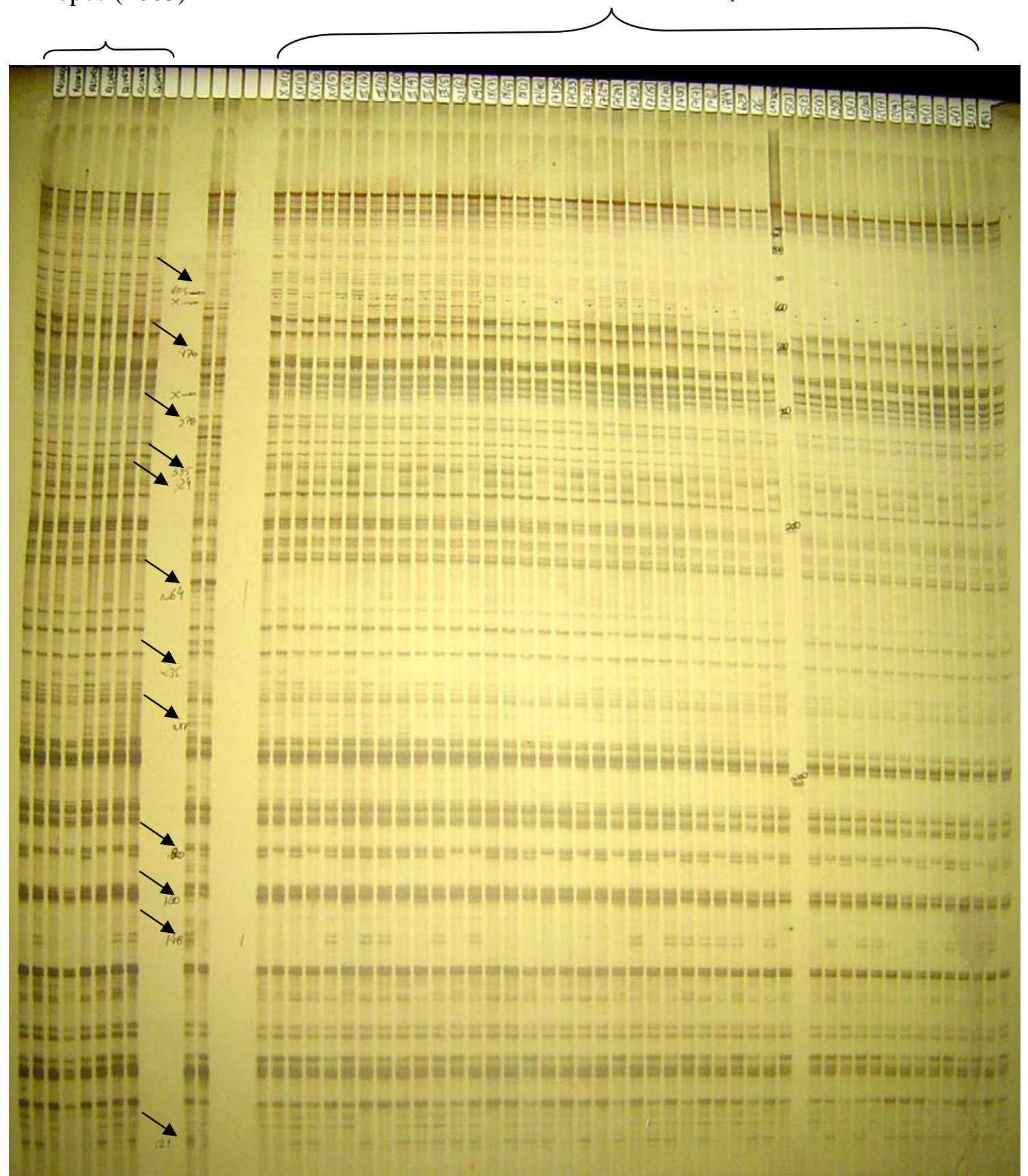

Figura 22 - Parte da imagem de um gel AFLP (combinação EM24) corado com nitrato de prata contendo indivíduos da população $F_{1}$, o marcador $100 \mathrm{pb}$, os genitores IAPAR-06 e IAPAR-123 (canaletas 44 e 45, a partir da esquerda) e algumas amostras de reações realizadas por Lopes (2003). Uma parte dos locos utilizados está indicada por setas 
Após a obtenção dos dados moleculares, referentes aos locos polimórficos, foi adotado o teste de aderência de $\chi^{2}$ (qui-quadrado), com nível de significância global e grau de liberdade igual a 1 , para verificar a hipótese nula $\left(\mathrm{H}_{0}\right)$ de segregação mendeliana (Tabela 15). Para tanto, foi utilizado o critério de Bonferroni (Rice, 1989), com um nível de significância dado por $\alpha \cong \alpha_{\mathrm{T}} / \mathrm{N}$, em que $\alpha_{\mathrm{T}}$ corresponde ao nível de significância global.

Caso fosse desconsiderado o nível de significância global e utilizado $\alpha=0,05$, haveria 54 marcadores (14,6\%) apresentando distorção de segregação. Entretanto, considerando $\alpha_{\mathrm{T}}=0,05$, tem-se $\alpha=(0,05 / 369)=0,000135$ e somente 5 marcadores com distorção. Das 54 marcas, 22 foram do tipo bi-parental e 32 informativas, sendo 15 oriundas do genitor IAPAR-06 e 17 do genitor IAPAR-123, indicando que as marcas informativas não são provenientes majoritariamente de um único genitor. Em lúpulo, ao contrário, considerando 224 marcadores utilizados para a construção de um mapa genético, 121 (54\%) foram oriundos do genitor feminino e apenas 49 (21,9\%) provenientes do genitor masculino (Seefelder et al. 2000).

Deve-se observar que, a rigor, os testes não são independentes, uma vez que aqueles marcadores pertencentes ao mesmo grupo de ligação co-segregam. Isso faz com que o critério de Bonferroni seja um pouco conservador, ou seja, o valor real de $\alpha_{\mathrm{T}}$ é menor do que o nominal, o que pode aumentar a dificuldade em se rejeitar $\mathrm{H}_{0}$ (Bearzoti, 2000). 
Tabela 15. Segregação dos marcadores AFLP, com o respectivo genitor informativo, número de indivíduos com os fenótipos moleculares observado na progênie, segregação esperada, valor do teste de qui-quadrado $\left(\chi^{2}\right)$, com 1 grau de liberdade, nível de significância e grupo de ligação ao qual a marca foi alocada

\begin{tabular}{|c|c|c|c|c|c|c|c|c|}
\hline \multirow{2}{*}{$\begin{array}{l}\text { Código do } \\
\text { marcador }\end{array}$} & \multirow{2}{*}{$\begin{array}{l}\text { Genitor } \\
\text { informativo }\end{array}$} & \multicolumn{3}{|c|}{ Fenótipos moleculares observados na progênie } & \multirow{2}{*}{$\begin{array}{l}\text { Segregação } \\
\text { esperada }\end{array}$} & \multirow{2}{*}{$\chi^{2}$} & \multirow{2}{*}{ "p-valor" } & \multirow{2}{*}{$\begin{array}{l}\text { Grupo de } \\
\text { ligação }\end{array}$} \\
\hline & & “0” & “1” & “ _ “ & & & & \\
\hline EM01161 & IAPAR-06 & 67 & 88 & 5 & {$[1: 1]$} & 2,85 & 0,091649 & 1 \\
\hline EM02208 & Ambos & 55 & 103 & 2 & {$[3: 1]$} & 8,11 & 0,004403 & $1^{*}$ \\
\hline EM04171 & IAPAR-06 & 86 & 74 & 0 & {$[1: 1]$} & 0,90 & 0,342782 & 1 \\
\hline EM04244 & IAPAR-123 & 88 & 72 & 0 & {$[1: 1]$} & 1,60 & 0,205903 & 1 \\
\hline EM07189 & IAPAR-06 & 70 & 84 & 6 & {$[1: 1]$} & 1,27 & 0,259256 & 1 \\
\hline EM07328 & IAPAR-06 & 85 & 75 & 0 & {$[1: 1]$} & 0,63 & 0,429195 & 1 \\
\hline EM10145 & IAPAR-123 & 88 & 69 & 3 & {$[1: 1]$} & 2,30 & 0,129427 & 1 \\
\hline EM12199 & IAPAR-123 & 89 & 70 & 1 & {$[1: 1]$} & 2,27 & 0,131862 & 1 \\
\hline EM13335 & IAPAR-123 & 87 & 69 & 4 & {$[1: 1]$} & 2,08 & 0,149541 & 1 \\
\hline EM151400 & IAPAR-123 & 74 & 86 & 0 & {$[1: 1]$} & 0,90 & 0,342782 & 1 \\
\hline EM15204 & IAPAR-123 & 88 & 67 & 5 & {$[1: 1]$} & 2,85 & 0,091649 & 1 \\
\hline EM15273 & IAPAR-123 & 71 & 81 & 8 & {$[1: 1]$} & 0,66 & 0,417304 & 1 \\
\hline EM16188 & IAPAR-06 & 86 & 73 & 1 & {$[1: 1]$} & 1,06 & 0,302557 & 1 \\
\hline EM16232 & IAPAR-123 & 88 & 70 & 2 & {$[1: 1]$} & 2,05 & 0,152143 & 1 \\
\hline EM16260 & IAPAR-123 & 88 & 71 & 1 & {$[1: 1]$} & 1,82 & 0,177598 & 1 \\
\hline EM16850 & Ambos & 30 & 83 & 47 & {$[3: 1]$} & 0,14 & 0,703806 & 1 \\
\hline EM1695 & Ambos & 35 & 111 & 14 & {$[3: 1]$} & 0,08 & 0,774349 & 1 \\
\hline EM18116 & IAPAR-06 & 79 & 81 & 0 & {$[1: 1]$} & 0,03 & 0,874367 & 1 \\
\hline EM1891 & Ambos & 71 & 88 & 1 & {$[3: 1]$} & 32,76 & 0,000000 & $1^{* * *}$ \\
\hline EM1892 & IAPAR-06 & 76 & 84 & 0 & {$[1: 1]$} & 0,40 & 0,527089 & 1 \\
\hline EM20321 & IAPAR-123 & 69 & 90 & 1 & {$[1: 1]$} & 2,77 & 0,095831 & 1 \\
\hline EM21161 & IAPAR-06 & 80 & 79 & 1 & {$[1: 1]$} & 0,01 & 0,936790 & 1 \\
\hline EM21304 & IAPAR-123 & 67 & 92 & 1 & {$[1: 1]$} & 3,93 & 0,047409 & $1^{*}$ \\
\hline EM22394 & IAPAR-06 & 70 & 86 & 4 & {$[1: 1]$} & 1,64 & 0,200185 & 1 \\
\hline EM24470 & IAPAR-123 & 85 & 71 & 4 & {$[1: 1]$} & 1,26 & 0,262332 & 1 \\
\hline PM02134 & IAPAR-06 & 64 & 53 & 43 & {$[1: 1]$} & 1,03 & 0,309177 & 1 \\
\hline PM06192 & IAPAR-123 & 86 & 72 & 2 & {$[1: 1]$} & 1,24 & 0,265374 & 1 \\
\hline PM08137 & IAPAR-123 & 76 & 82 & 2 & {$[1: 1]$} & 0,23 & 0,633124 & 1 \\
\hline PM08192 & IAPAR-123 & 82 & 74 & 4 & {$[1: 1]$} & 0,41 & 0,521839 & 1 \\
\hline PM10186 & IAPAR-06 & 91 & 68 & 1 & {$[1: 1]$} & 3,33 & 0,068149 & 1 \\
\hline EM01130 & IAPAR-06 & 69 & 87 & 4 & {$[1: 1]$} & 2,08 & 0,149541 & 2 \\
\hline EM01234 & IAPAR-06 & 80 & 76 & 4 & {$[1: 1]$} & 0,10 & 0,748774 & 2 \\
\hline EM01238 & IAPAR-123 & 60 & 96 & 4 & {$[1: 1]$} & 8,31 & 0,003948 & $2^{*}$ \\
\hline EM021037 & IAPAR-123 & 73 & 85 & 2 & {$[1: 1]$} & 0,91 & 0,339745 & 2 \\
\hline EM02144 & IAPAR-123 & 83 & 75 & 2 & {$[1: 1]$} & 0,41 & 0,524486 & 2 \\
\hline EM02145 & IAPAR-123 & 76 & 82 & 2 & {$[1: 1]$} & 0,23 & 0,633124 & 2 \\
\hline EM02242 & Ambos & 27 & 131 & 2 & {$[3: 1]$} & 5,27 & 0,021643 & $2 *$ \\
\hline EM03264 & IAPAR-123 & 67 & 92 & 1 & {$[1: 1]$} & 3,93 & 0,047409 & $2^{*}$ \\
\hline
\end{tabular}


Tabela 15. Segregação dos marcadores AFLP, com o respectivo genitor informativo, número de indivíduos com os fenótipos moleculares observado na progênie, segregação esperada, valor do teste de qui-quadrado $\left(\chi^{2}\right)$, com 1 grau de liberdade, nível de significância e grupo de ligação ao qual a marca foi alocada

\begin{tabular}{|c|c|c|c|c|c|c|c|c|}
\hline \multirow{2}{*}{$\begin{array}{l}\text { Código do } \\
\text { marcador }\end{array}$} & \multirow{2}{*}{$\begin{array}{l}\text { Genitor } \\
\text { informativo }\end{array}$} & \multicolumn{3}{|c|}{ Fenótipos moleculares observados na progênie } & \multirow{2}{*}{$\begin{array}{l}\text { Segregação } \\
\text { esperada }\end{array}$} & \multirow{2}{*}{$\chi^{2}$} & \multirow{2}{*}{ "p-valor" } & \multirow{2}{*}{$\begin{array}{l}\text { Grupo de } \\
\text { ligação }\end{array}$} \\
\hline & & “0” & “1” & “ _ “ & & & & \\
\hline EM03276 & IAPAR-123 & 92 & 67 & 1 & {$[1: 1]$} & 3,93 & 0,047409 & $2 *$ \\
\hline EM03424 & IAPAR-06 & 68 & 48 & 44 & {$[1: 1]$} & 3,45 & 0,063318 & 2 \\
\hline EM04138 & IAPAR-123 & 67 & 93 & 0 & {$[1: 1]$} & 4,23 & 0,039833 & $2 *$ \\
\hline EM05232 & IAPAR-06 & 82 & 78 & 0 & {$[1: 1]$} & 0,10 & 0,751830 & 2 \\
\hline EM05244 & IAPAR-123 & 67 & 93 & 0 & {$[1: 1]$} & 4,23 & 0,039833 & $2 *$ \\
\hline EM05262 & Ambos & 31 & 129 & 0 & {$[3: 1]$} & 2,70 & 0,100348 & 2 \\
\hline EM061227 & IAPAR-123 & 75 & 84 & 1 & {$[1: 1]$} & 0,51 & 0,475384 & 2 \\
\hline EM07460 & IAPAR-123 & 67 & 87 & 6 & {$[1: 1]$} & 2,60 & 0,107039 & 2 \\
\hline EM0799 & IAPAR-06 & 86 & 74 & 0 & {$[1: 1]$} & 0,90 & 0,342782 & 2 \\
\hline EM08114 & IAPAR-06 & 69 & 83 & 8 & {$[1: 1]$} & 1,29 & 0,256145 & 2 \\
\hline EM081497 & Ambos & 34 & 81 & 45 & {$[3: 1]$} & 1,28 & 0,258223 & 2 \\
\hline EM08570 & IAPAR-06 & 73 & 86 & 1 & {$[1: 1]$} & 1,06 & 0,302557 & 2 \\
\hline EM09121 & IAPAR-06 & 68 & 82 & 10 & {$[1: 1]$} & 1,31 & 0,252999 & 2 \\
\hline EM09177 & IAPAR-06 & 82 & 77 & 1 & {$[1: 1]$} & 0,16 & 0,691717 & 2 \\
\hline EM09380 & Ambos & 21 & 80 & 59 & {$[3: 1]$} & 0,95 & 0,328755 & 2 \\
\hline EM0970 & Ambos & 39 & 77 & 44 & {$[3: 1]$} & 4,60 & 0,032015 & $2 *$ \\
\hline EM10300 & IAPAR-123 & 73 & 84 & 3 & {$[1: 1]$} & 0,77 & 0,380000 & 2 \\
\hline EM12167 & IAPAR-123 & 92 & 67 & 1 & {$[1: 1]$} & 3,93 & 0,047409 & $2 *$ \\
\hline EM13100 & IAPAR-06 & 72 & 72 & 16 & {$[1: 1]$} & 0,00 & 1,000000 & 2 \\
\hline EM13121 & Ambos & 23 & 35 & 102 & [3:1] & 6,64 & 0,009951 & $2 *$ \\
\hline EM13224 & Ambos & 27 & 128 & 5 & {$[3: 1]$} & 4,75 & 0,029289 & $2 *$ \\
\hline EM13226 & IAPAR-06 & 74 & 83 & 3 & {$[1: 1]$} & 0,52 & 0,472586 & 2 \\
\hline EM13275 & IAPAR-06 & 72 & 81 & 7 & {$[1: 1]$} & 0,53 & 0,466854 & 2 \\
\hline EM13450 & Ambos & 25 & 76 & 59 & {$[3: 1]$} & 0,00 & 0,954188 & 2 \\
\hline EM13620 & IAPAR-06 & 80 & 75 & 5 & {$[1: 1]$} & 0,16 & 0,687971 & 2 \\
\hline EM14253 & Ambos & 22 & 72 & 66 & {$[3: 1]$} & 0,13 & 0,720871 & 2 \\
\hline EM14379 & IAPAR-123 & 74 & 86 & 0 & {$[1: 1]$} & 0,90 & 0,342782 & 2 \\
\hline EM14405 & IAPAR-06 & 79 & 76 & 5 & [1:1] & 0,06 & 0,809582 & 2 \\
\hline EM1478 & IAPAR-06 & 82 & 71 & 7 & {$[1: 1]$} & 0,79 & 0,373843 & 2 \\
\hline EM1484 & Ambos & 37 & 123 & 0 & [3:1] & 0,30 & 0,583882 & 2 \\
\hline EM14950 & IAPAR-123 & 52 & 54 & 54 & {$[1: 1]$} & 0,04 & 0,845975 & 2 \\
\hline EM1496 & Ambos & 42 & 118 & 0 & {$[3: 1]$} & 0,13 & 0,715001 & 2 \\
\hline EM16512 & IAPAR-06 & 78 & 81 & 1 & {$[1: 1]$} & 0,06 & 0,811947 & 2 \\
\hline EM16618 & Ambos & 17 & 51 & 92 & {$[3: 1]$} & 0,00 & 1,000000 & 2 \\
\hline EM16675 & IAPAR-123 & 65 & 92 & 3 & {$[1: 1]$} & 4,64 & 0,031175 & $2^{*}$ \\
\hline EM16715 & Ambos & 40 & 119 & 1 & {$[3: 1]$} & 0,00 & 0,963480 & 2 \\
\hline EM16910 & IAPAR-06 & 68 & 89 & 3 & {$[1: 1]$} & 2,81 & 0,093742 & 2 \\
\hline EM17125 & IAPAR-123 & 68 & 89 & 3 & {$[1: 1]$} & 2,81 & 0,093742 & 2 \\
\hline
\end{tabular}


Tabela 15. Segregação dos marcadores AFLP, com o respectivo genitor informativo, número de indivíduos com os fenótipos moleculares observado na progênie, segregação esperada, valor do teste de qui-quadrado $\left(\chi^{2}\right)$, com 1 grau de liberdade, nível de significância e grupo de ligação ao qual a marca foi alocada

\begin{tabular}{|c|c|c|c|c|c|c|c|c|}
\hline \multirow{2}{*}{$\begin{array}{l}\text { Código do } \\
\text { marcador }\end{array}$} & \multirow{2}{*}{$\begin{array}{l}\text { Genitor } \\
\text { informativo }\end{array}$} & \multicolumn{3}{|c|}{ Fenótipos moleculares observados na progênie } & \multirow{2}{*}{$\begin{array}{l}\text { Segregação } \\
\text { esperada }\end{array}$} & \multirow{2}{*}{$\chi^{2}$} & \multirow{2}{*}{ "p-valor" } & \multirow{2}{*}{$\begin{array}{l}\text { Grupo de } \\
\text { ligação }\end{array}$} \\
\hline & & “0” & “1” & “_ “ & & & & \\
\hline EM1790 & IAPAR-06 & 73 & 84 & 3 & {$[1: 1]$} & 0,77 & 0,380000 & 2 \\
\hline EM18137 & IAPAR-123 & 69 & 91 & 0 & {$[1: 1]$} & 3,03 & 0,081990 & 2 \\
\hline EM18139 & IAPAR-123 & 68 & 65 & 27 & {$[1: 1]$} & 0,07 & 0,794761 & 2 \\
\hline EM18217 & Ambos & 38 & 115 & 7 & {$[3: 1]$} & 0,00 & 0,962771 & 2 \\
\hline EM18218 & Ambos & 33 & 120 & 7 & {$[3: 1]$} & 0,96 & 0,326989 & 2 \\
\hline EM18332 & IAPAR-123 & 79 & 80 & 1 & {$[1: 1]$} & 0,01 & 0,936790 & 2 \\
\hline EM18489 & IAPAR-06 & 76 & 83 & 1 & {$[1: 1]$} & 0,31 & 0,578802 & 2 \\
\hline EM18506 & IAPAR-06 & 61 & 55 & 44 & {$[1: 1]$} & 0,31 & 0,577469 & 2 \\
\hline EM19276 & IAPAR-123 & 72 & 84 & 4 & {$[1: 1]$} & 0,92 & 0,336668 & 2 \\
\hline EM20107 & IAPAR-06 & 76 & 82 & 2 & {$[1: 1]$} & 0,23 & 0,633124 & 2 \\
\hline EM20201 & IAPAR-06 & 83 & 76 & 1 & {$[1: 1]$} & 0,31 & 0,578802 & 2 \\
\hline EM20261 & IAPAR-123 & 65 & 94 & 1 & {$[1: 1]$} & 5,29 & 0,021457 & $2 *$ \\
\hline EM20284 & Ambos & 36 & 123 & 1 & {$[3: 1]$} & 0,47 & 0,492207 & 2 \\
\hline EM20288 & Ambos & 37 & 122 & 1 & {$[3: 1]$} & 0,25 & 0,614504 & 2 \\
\hline EM20326 & IAPAR-06 & 87 & 72 & 1 & {$[1: 1]$} & 1,42 & 0,234213 & 2 \\
\hline EM21124 & IAPAR-123 & 71 & 88 & 1 & {$[1: 1]$} & 1,82 & 0,177598 & 2 \\
\hline EM21179 & IAPAR-06 & 82 & 77 & 1 & {$[1: 1]$} & 0,16 & 0,691717 & 2 \\
\hline EM21204 & IAPAR-123 & 73 & 86 & 1 & {$[1: 1]$} & 1,06 & 0,302557 & 2 \\
\hline EM21254 & IAPAR-123 & 78 & 81 & 1 & {$[1: 1]$} & 0,06 & 0,811947 & 2 \\
\hline EM21259 & IAPAR-123 & 64 & 95 & 1 & {$[1: 1]$} & 6,04 & 0,013953 & $2 *$ \\
\hline EM2161 & IAPAR-06 & 53 & 63 & 44 & {$[1: 1]$} & 0,86 & 0,353160 & 2 \\
\hline EM22151 & IAPAR-06 & 66 & 94 & 0 & {$[1: 1]$} & 4,90 & 0,026857 & $2 *$ \\
\hline EM22265 & IAPAR-06 & 76 & 84 & 0 & {$[1: 1]$} & 0,40 & 0,527089 & 2 \\
\hline EM22307 & IAPAR-06 & 65 & 95 & 0 & {$[1: 1]$} & 5,63 & 0,017706 & $2 *$ \\
\hline EM23198 & IAPAR-06 & 57 & 59 & 44 & {$[1: 1]$} & 0,03 & 0,852684 & 2 \\
\hline EM23222 & IAPAR-123 & 50 & 65 & 45 & {$[1: 1]$} & 1,96 & 0,161886 & 2 \\
\hline EM23317 & IAPAR-06 & 64 & 51 & 45 & {$[1: 1]$} & 1,47 & 0,225414 & 2 \\
\hline EM2378 & IAPAR-123 & 58 & 58 & 44 & {$[1: 1]$} & 0,00 & 1,000000 & 2 \\
\hline EM24124 & Ambos & 43 & 113 & 4 & {$[3: 1]$} & 0,55 & 0,459543 & 2 \\
\hline EM24264 & IAPAR-06 & 90 & 69 & 1 & {$[1: 1]$} & 2,77 & 0,095831 & 2 \\
\hline EM24605 & IAPAR-06 & 48 & 67 & 45 & {$[1: 1]$} & 3,14 & 0,076435 & 2 \\
\hline EM24750 & Ambos & 36 & 63 & 61 & {$[3: 1]$} & 6,82 & 0,009023 & $2 *$ \\
\hline EM2488 & IAPAR-123 & 67 & 92 & 1 & {$[1: 1]$} & 3,93 & 0,047409 & $2 *$ \\
\hline PM01332 & IAPAR-06 & 90 & 63 & 7 & {$[1: 1]$} & 4,76 & 0,029049 & $2^{*}$ \\
\hline PM02131 & IAPAR-123 & 51 & 65 & 44 & {$[1: 1]$} & 1,69 & 0,193647 & 2 \\
\hline PM02640 & Ambos & 18 & 42 & 100 & {$[3: 1]$} & 0,80 & 0,371093 & 2 \\
\hline PM03338 & IAPAR-123 & 47 & 70 & 43 & {$[1: 1]$} & 4,52 & 0,033474 & $2^{*}$ \\
\hline PM0368 & Ambos & 34 & 126 & 0 & {$[3: 1]$} & 1,20 & 0,273322 & 2 \\
\hline
\end{tabular}


Tabela 15. Segregação dos marcadores AFLP, com o respectivo genitor informativo, número de indivíduos com os fenótipos moleculares observado na progênie, segregação esperada, valor do teste de qui-quadrado $\left(\chi^{2}\right)$, com 1 grau de liberdade, nível de significância e grupo de ligação ao qual a marca foi alocada

\begin{tabular}{|c|c|c|c|c|c|c|c|c|}
\hline \multirow{2}{*}{$\begin{array}{l}\text { Código do } \\
\text { marcador }\end{array}$} & \multirow{2}{*}{$\begin{array}{l}\text { Genitor } \\
\text { informativo }\end{array}$} & \multicolumn{3}{|c|}{ Fenótipos moleculares observados na progênie } & \multirow{2}{*}{$\begin{array}{l}\text { Segregação } \\
\text { esperada }\end{array}$} & \multirow{2}{*}{$\chi^{2}$} & \multirow{2}{*}{ "p-valor" } & \multirow{2}{*}{$\begin{array}{l}\text { Grupo de } \\
\text { ligação }\end{array}$} \\
\hline & & “0” & “1” & “ - “ & & & & \\
\hline PM04531 & IAPAR-06 & 69 & 87 & 4 & {$[1: 1]$} & 2,08 & 0,149541 & 2 \\
\hline PM06226 & Ambos & 59 & 100 & 1 & {$[3: 1]$} & 12,43 & 0,000423 & $2 *$ \\
\hline PM06237 & IAPAR-06 & 69 & 90 & 1 & {$[1: 1]$} & 2,77 & 0,095831 & 2 \\
\hline PM06239 & IAPAR-123 & 67 & 91 & 2 & {$[1: 1]$} & 3,65 & 0,056219 & 2 \\
\hline PM07341 & Ambos & 37 & 122 & 1 & {$[3: 1]$} & 0,25 & 0,614504 & 2 \\
\hline PM09144 & IAPAR-06 & 78 & 69 & 13 & {$[1: 1]$} & 0,55 & 0,457901 & 2 \\
\hline PM09198 & IAPAR-123 & 78 & 65 & 17 & {$[1: 1]$} & 1,18 & 0,276986 & 2 \\
\hline PM10149 & IAPAR-123 & 97 & 63 & 0 & {$[1: 1]$} & 7,23 & 0,007190 & $2 *$ \\
\hline EM02369 & IAPAR-06 & 72 & 86 & 2 & {$[1: 1]$} & 1,24 & 0,265374 & 3 \\
\hline EM04114 & IAPAR-123 & 83 & 77 & 0 & {$[1: 1]$} & 0,23 & 0,635256 & 3 \\
\hline EM062644 & Ambos & 46 & 103 & 11 & {$[3: 1]$} & 2,74 & 0,097835 & 3 \\
\hline EM06684 & IAPAR-123 & 77 & 83 & 0 & {$[1: 1]$} & 0,23 & 0,635256 & 3 \\
\hline EM09146 & IAPAR-123 & 84 & 75 & 1 & {$[1: 1]$} & 0,51 & 0,475384 & 3 \\
\hline EM09155 & IAPAR-06 & 78 & 81 & 1 & {$[1: 1]$} & 0,06 & 0,811947 & 3 \\
\hline EM10233 & Ambos & 41 & 114 & 5 & {$[3: 1]$} & 0,17 & 0,676411 & 3 \\
\hline EM10236 & IAPAR-123 & 80 & 76 & 4 & {$[1: 1]$} & 0,10 & 0,748774 & 3 \\
\hline EM17240 & IAPAR-123 & 82 & 75 & 3 & {$[1: 1]$} & 0,31 & 0,576393 & 3 \\
\hline EM19162 & Ambos & 15 & 85 & 60 & {$[3: 1]$} & 5,33 & 0,020921 & $3 *$ \\
\hline EM20135 & IAPAR-06 & 77 & 82 & 1 & {$[1: 1]$} & 0,16 & 0,691717 & 3 \\
\hline EM22272 & Ambos & 39 & 121 & 0 & [3:1] & 0,03 & 0,855132 & 3 \\
\hline EM22433 & IAPAR-123 & 76 & 76 & 8 & {$[1: 1]$} & 0,00 & 1,000000 & 3 \\
\hline EM23650 & IAPAR-123 & 53 & 62 & 45 & {$[1: 1]$} & 0,70 & 0,401327 & 3 \\
\hline EM24217 & IAPAR-123 & 82 & 76 & 2 & {$[1: 1]$} & 0,23 & 0,633124 & 3 \\
\hline EM2484 & IAPAR-06 & 70 & 89 & 1 & {$[1: 1]$} & 2,27 & 0,131862 & 3 \\
\hline PM06161 & IAPAR-06 & 82 & 74 & 4 & {$[1: 1]$} & 0,41 & 0,521839 & 3 \\
\hline PM08161 & IAPAR-06 & 84 & 67 & 9 & {$[1: 1]$} & 1,91 & 0,166530 & 3 \\
\hline PM10267 & IAPAR-123 & 70 & 85 & 5 & {$[1: 1]$} & 1,45 & 0,228269 & 3 \\
\hline EM02230 & IAPAR-123 & 69 & 89 & 2 & [1:1] & 2,53 & 0,111584 & 4 \\
\hline EM03174 & IAPAR-06 & 101 & 58 & 1 & {$[1: 1]$} & 11,63 & 0,000649 & $4^{*}$ \\
\hline EM04158 & Ambos & 32 & 128 & 0 & {$[3: 1]$} & 2,13 & 0,144127 & 4 \\
\hline EM04192 & IAPAR-123 & 93 & 67 & 0 & {$[1: 1]$} & 4,23 & 0,039833 & $4^{*}$ \\
\hline EM0463 & IAPAR-06 & 60 & 57 & 43 & {$[1: 1]$} & 0,08 & 0,781511 & 4 \\
\hline EM04647 & IAPAR-06 & 91 & 69 & 0 & {$[1: 1]$} & 3,03 & 0,081990 & 4 \\
\hline EM06119 & IAPAR-06 & 92 & 62 & 6 & {$[1: 1]$} & 5,84 & 0,015629 & $4^{*}$ \\
\hline EM08348 & IAPAR-06 & 56 & 103 & 1 & {$[1: 1]$} & 13,89 & 0,000194 & $4^{*}$ \\
\hline EM11278 & IAPAR-06 & 67 & 90 & 3 & [1:1] & 3,37 & 0,066417 & 4 \\
\hline EM11321 & IAPAR-06 & 67 & 90 & 3 & {$[1: 1]$} & 3,37 & 0,066417 & 4 \\
\hline EM12182 & IAPAR-06 & 65 & 94 & 1 & {$[1: 1]$} & 5,29 & 0,021457 & $4^{*}$ \\
\hline
\end{tabular}


Tabela 15. Segregação dos marcadores AFLP, com o respectivo genitor informativo, número de indivíduos com os fenótipos moleculares observado na progênie, segregação esperada, valor do teste de qui-quadrado $\left(\chi^{2}\right)$, com 1 grau de liberdade, nível de significância e grupo de ligação ao qual a marca foi alocada

\begin{tabular}{|c|c|c|c|c|c|c|c|c|}
\hline \multirow{2}{*}{$\begin{array}{l}\text { Código do } \\
\text { marcador }\end{array}$} & \multirow{2}{*}{$\begin{array}{l}\text { Genitor } \\
\text { informativo }\end{array}$} & \multicolumn{3}{|c|}{ Fenótipos moleculares observados na progênie } & \multirow{2}{*}{$\begin{array}{l}\text { Segregação } \\
\text { esperada }\end{array}$} & \multirow{2}{*}{$\chi^{2}$} & \multirow{2}{*}{ "p-valor" } & \multirow{2}{*}{$\begin{array}{l}\text { Grupo de } \\
\text { ligação }\end{array}$} \\
\hline & & “0” & “1” & “ _ “ & & & & \\
\hline EM1387 & IAPAR-06 & 78 & 78 & 4 & {$[1: 1]$} & 0,00 & 1,000000 & 4 \\
\hline EM1392 & IAPAR-123 & 73 & 81 & 6 & {$[1: 1]$} & 0,42 & 0,519149 & 4 \\
\hline EM151050 & IAPAR-123 & 94 & 66 & 0 & {$[1: 1]$} & 4,90 & 0,026857 & $4^{*}$ \\
\hline EM15237 & IAPAR-06 & 84 & 71 & 5 & {$[1: 1]$} & 1,09 & 0,296400 & 4 \\
\hline EM15800 & Ambos & 32 & 128 & 0 & {$[3: 1]$} & 2,13 & 0,144127 & 4 \\
\hline EM16308 & IAPAR-123 & 80 & 78 & 2 & {$[1: 1]$} & 0,03 & 0,873581 & 4 \\
\hline EM16725 & Ambos & 40 & 119 & 1 & {$[3: 1]$} & 0,00 & 0,963480 & 4 \\
\hline EM17360 & IAPAR-06 & 80 & 76 & 4 & {$[1: 1]$} & 0,10 & 0,748774 & 4 \\
\hline EM1992 & Ambos & 33 & 121 & 6 & {$[3: 1]$} & 1,05 & 0,306056 & 4 \\
\hline EM1998 & Ambos & 56 & 98 & 6 & {$[3: 1]$} & 10,61 & 0,001127 & $4^{*}$ \\
\hline EM20131 & IAPAR-123 & 69 & 89 & 2 & {$[1: 1]$} & 2,53 & 0,111584 & 4 \\
\hline EM20172 & IAPAR-06 & 72 & 87 & 1 & {$[1: 1]$} & 1,42 & 0,234213 & 4 \\
\hline EM20231 & IAPAR-123 & 71 & 88 & 1 & {$[1: 1]$} & 1,82 & 0,177598 & 4 \\
\hline EM22112 & IAPAR-123 & 79 & 72 & 9 & {$[1: 1]$} & 0,32 & 0,568914 & 4 \\
\hline EM22164 & Ambos & 57 & 103 & 0 & {$[3: 1]$} & 9,63 & 0,001911 & $4^{*}$ \\
\hline EM2276 & IAPAR-123 & 78 & 75 & 7 & {$[1: 1]$} & 0,06 & 0,808365 & 4 \\
\hline EM2296 & IAPAR-123 & 86 & 74 & 0 & {$[1: 1]$} & 0,90 & 0,342782 & 4 \\
\hline EM24121 & IAPAR-123 & 68 & 91 & 1 & {$[1: 1]$} & 3,33 & 0,068149 & 4 \\
\hline EM24235 & IAPAR-123 & 90 & 67 & 3 & {$[1: 1]$} & 3,37 & 0,066417 & 4 \\
\hline PM01148 & IAPAR-123 & 72 & 81 & 7 & {$[1: 1]$} & 0,53 & 0,466854 & 4 \\
\hline PM06186 & IAPAR-123 & 75 & 84 & 1 & {$[1: 1]$} & 0,51 & 0,475384 & 4 \\
\hline PM10114 & IAPAR-123 & 71 & 89 & 0 & {$[1: 1]$} & 2,03 & 0,154729 & 4 \\
\hline EM011623 & IAPAR-06 & 82 & 73 & 5 & {$[1: 1]$} & 0,52 & 0,469743 & 5 \\
\hline EM01395 & IAPAR-06 & 85 & 71 & 4 & {$[1: 1]$} & 1,26 & 0,262332 & 5 \\
\hline EM01525 & IAPAR-123 & 78 & 78 & 4 & {$[1: 1]$} & 0,00 & 1,000000 & 5 \\
\hline EM02110 & IAPAR-06 & 89 & 69 & 2 & {$[1: 1]$} & 2,53 & 0,111584 & 5 \\
\hline EM02114 & Ambos & 47 & 111 & 2 & {$[3: 1]$} & 1,90 & 0,168220 & 5 \\
\hline EM02256 & IAPAR-06 & 66 & 92 & 2 & {$[1: 1]$} & 4,28 & 0,038598 & $5^{*}$ \\
\hline EM02309 & IAPAR-123 & 75 & 83 & 2 & {$[1: 1]$} & 0,41 & 0,524486 & 5 \\
\hline EM03234 & IAPAR-123 & 75 & 83 & 2 & {$[1: 1]$} & 0,41 & 0,524486 & 5 \\
\hline EM05183 & Ambos & 23 & 73 & 64 & {$[3: 1]$} & 0,06 & 0,813664 & 5 \\
\hline EM06146 & IAPAR-123 & 55 & 62 & 43 & {$[1: 1]$} & 0,42 & 0,517535 & 5 \\
\hline EM06204 & Ambos & 36 & 81 & 43 & {$[3: 1]$} & 2,08 & 0,149541 & 5 \\
\hline EM06273 & IAPAR-123 & 74 & 84 & 2 & {$[1: 1]$} & 0,63 & 0,426289 & 5 \\
\hline EM08243 & IAPAR-123 & 76 & 83 & 1 & {$[1: 1]$} & 0,31 & 0,578802 & 5 \\
\hline EM0881 & IAPAR-123 & 75 & 84 & 1 & {$[1: 1]$} & 0,51 & 0,475384 & 5 \\
\hline EM091050 & IAPAR-06 & 90 & 68 & 2 & {$[1: 1]$} & 3,06 & 0,080079 & 5 \\
\hline EM09127 & Ambos & 50 & 109 & 1 & {$[3: 1]$} & 3,52 & 0,060482 & 5 \\
\hline
\end{tabular}


Tabela 15. Segregação dos marcadores AFLP, com o respectivo genitor informativo, número de indivíduos com os fenótipos moleculares observado na progênie, segregação esperada, valor do teste de qui-quadrado $\left(\chi^{2}\right)$, com 1 grau de liberdade, nível de significância e grupo de ligação ao qual a marca foi alocada

\begin{tabular}{|c|c|c|c|c|c|c|c|c|}
\hline \multirow{2}{*}{$\begin{array}{l}\text { Código do } \\
\text { marcador }\end{array}$} & \multirow{2}{*}{$\begin{array}{l}\text { Genitor } \\
\text { informativo }\end{array}$} & \multicolumn{3}{|c|}{ Fenótipos moleculares observados na progênie } & \multirow{2}{*}{$\begin{array}{l}\text { Segregação } \\
\text { esperada }\end{array}$} & \multirow{2}{*}{$\chi^{2}$} & \multirow{2}{*}{ "p-valor" } & \multirow{2}{*}{$\begin{array}{l}\text { Grupo de } \\
\text { ligação }\end{array}$} \\
\hline & & “0” & “1” & “ _ “ & & & & \\
\hline EM0985 & Ambos & 35 & 81 & 44 & [3:1] & 1,66 & 0,198256 & 5 \\
\hline EM10121 & IAPAR-06 & 88 & 68 & 4 & {$[1: 1]$} & 2,56 & 0,109315 & 5 \\
\hline EM11291 & IAPAR-123 & 74 & 83 & 3 & {$[1: 1]$} & 0,52 & 0,472586 & 5 \\
\hline EM12555 & IAPAR-123 & 43 & 61 & 56 & {$[1: 1]$} & 3,12 & 0,077556 & 5 \\
\hline EM13340 & IAPAR-06 & 88 & 69 & 3 & {$[1: 1]$} & 2,30 & 0,129427 & 5 \\
\hline EM15248 & IAPAR-123 & 75 & 80 & 5 & {$[1: 1]$} & 0,16 & 0,687971 & 5 \\
\hline EM161100 & IAPAR-06 & 62 & 94 & 4 & {$[1: 1]$} & 6,56 & 0,010406 & $5^{*}$ \\
\hline EM16270 & Ambos & 43 & 116 & 1 & {$[3: 1]$} & 0,35 & 0,551690 & 5 \\
\hline EM16354 & IAPAR-06 & 65 & 94 & 1 & {$[1: 1]$} & 5,29 & 0,021457 & $5^{*}$ \\
\hline EM17219 & IAPAR-123 & 75 & 82 & 3 & {$[1: 1]$} & 0,31 & 0,576393 & 5 \\
\hline EM17230 & IAPAR-123 & 75 & 82 & 3 & {$[1: 1]$} & 0,31 & 0,576393 & 5 \\
\hline EM17270 & Ambos & 77 & 79 & 4 & {$[3: 1]$} & 49,37 & 0,000000 & $5^{* * *}$ \\
\hline EM18257 & Ambos & 48 & 112 & 0 & [3:1] & 2,13 & 0,144127 & 5 \\
\hline EM19226 & IAPAR-06 & 68 & 90 & 2 & {$[1: 1]$} & 3,06 & 0,080079 & 5 \\
\hline EM19246 & IAPAR-123 & 74 & 84 & 2 & {$[1: 1]$} & 0,63 & 0,426289 & 5 \\
\hline EM20155 & Ambos & 34 & 121 & 5 & {$[3: 1]$} & 0,78 & 0,378262 & 5 \\
\hline EM20219 & Ambos & 50 & 103 & 7 & {$[3: 1]$} & 4,81 & 0,028252 & $5^{*}$ \\
\hline EM21243 & IAPAR-06 & 91 & 68 & 1 & {$[1: 1]$} & 3,33 & 0,068149 & 5 \\
\hline EM21750 & IAPAR-123 & 75 & 84 & 1 & {$[1: 1]$} & 0,51 & 0,475384 & 5 \\
\hline EM2190 & Ambos & 44 & 113 & 3 & {$[3: 1]$} & 0,77 & 0,381316 & 5 \\
\hline EM2193 & IAPAR-06 & 62 & 93 & 5 & {$[1: 1]$} & 6,20 & 0,012775 & $5^{*}$ \\
\hline EM22525 & IAPAR-123 & 61 & 52 & 47 & {$[1: 1]$} & 0,72 & 0,397191 & 5 \\
\hline EM23750 & Ambos & 45 & 69 & 46 & {$[3: 1]$} & 12,74 & 0,000359 & $5^{*}$ \\
\hline EM24148 & IAPAR-123 & 73 & 72 & 15 & {$[1: 1]$} & 0,01 & 0,933815 & 5 \\
\hline EM24324 & IAPAR-06 & 66 & 92 & 2 & {$[1: 1]$} & 4,28 & 0,038598 & $5^{*}$ \\
\hline PM02546 & IAPAR-123 & 56 & 61 & 43 & {$[1: 1]$} & 0,21 & 0,643902 & 5 \\
\hline PM03113 & IAPAR-123 & 75 & 84 & 1 & {$[1: 1]$} & 0,51 & 0,475384 & 5 \\
\hline PM03141 & IAPAR-123 & 84 & 76 & 0 & {$[1: 1]$} & 0,40 & 0,527089 & 5 \\
\hline PM03182 & Ambos & 35 & 125 & 0 & {$[3: 1]$} & 0,83 & 0,361310 & 5 \\
\hline PM03188 & Ambos & 74 & 86 & 0 & {$[3: 1]$} & 38,53 & 0,000000 & $5^{* * *}$ \\
\hline PM03265 & Ambos & 33 & 125 & 2 & {$[3: 1]$} & 1,43 & 0,232392 & 5 \\
\hline PM04184 & Ambos & 44 & 113 & 3 & {$[3: 1]$} & 0,77 & 0,381316 & 5 \\
\hline PM04214 & Ambos & 49 & 105 & 6 & {$[3: 1]$} & 3,82 & 0,050699 & 5 \\
\hline PM04240 & IAPAR-06 & 77 & 76 & 7 & {$[1: 1]$} & 0,01 & 0,935565 & 5 \\
\hline PM04243 & IAPAR-123 & 64 & 92 & 4 & {$[1: 1]$} & 5,03 & 0,024975 & $5^{*}$ \\
\hline PM07170 & IAPAR-123 & 81 & 79 & 0 & {$[1: 1]$} & 0,03 & 0,874367 & 5 \\
\hline EM01156 & IAPAR-123 & 74 & 82 & 4 & {$[1: 1]$} & 0,41 & 0,521839 & 6 \\
\hline EM01800 & Ambos & 43 & 114 & 3 & {$[3: 1]$} & 0,48 & 0,489463 & 6 \\
\hline
\end{tabular}


Tabela 15. Segregação dos marcadores AFLP, com o respectivo genitor informativo, número de indivíduos com os fenótipos moleculares observado na progênie, segregação esperada, valor do teste de qui-quadrado $\left(\chi^{2}\right)$, com 1 grau de liberdade, nível de significância e grupo de ligação ao qual a marca foi alocada

\begin{tabular}{|c|c|c|c|c|c|c|c|c|}
\hline \multirow{2}{*}{$\begin{array}{l}\text { Código do } \\
\text { marcador }\end{array}$} & \multirow{2}{*}{$\begin{array}{l}\text { Genitor } \\
\text { informativo }\end{array}$} & \multicolumn{3}{|c|}{ Fenótipos moleculares observados na progênie } & \multirow{2}{*}{$\begin{array}{l}\text { Segregação } \\
\text { esperada }\end{array}$} & \multirow{2}{*}{$\chi^{2}$} & \multirow{2}{*}{ "p-valor" } & \multirow{2}{*}{$\begin{array}{l}\text { Grupo de } \\
\text { ligação }\end{array}$} \\
\hline & & “0” & “1” & “ _ “ & & & & \\
\hline EM021560 & IAPAR-06 & 87 & 70 & 3 & {$[1: 1]$} & 1,84 & 0,174861 & 6 \\
\hline EM02509 & Ambos & 30 & 128 & 2 & {$[3: 1]$} & 3,05 & 0,080916 & 6 \\
\hline EM03219 & IAPAR-123 & 78 & 81 & 1 & {$[1: 1]$} & 0,06 & 0,811947 & 6 \\
\hline EM08395 & IAPAR-123 & 72 & 87 & 1 & {$[1: 1]$} & 1,42 & 0,234213 & 6 \\
\hline EM11800 & IAPAR-123 & 78 & 79 & 3 & {$[1: 1]$} & 0,01 & 0,936389 & 6 \\
\hline EM13880 & IAPAR-123 & 77 & 75 & 8 & {$[1: 1]$} & 0,03 & 0,871131 & 6 \\
\hline EM16397 & IAPAR-06 & 94 & 64 & 2 & {$[1: 1]$} & 5,70 & 0,017002 & $6^{*}$ \\
\hline EM16406 & IAPAR-123 & 79 & 80 & 1 & {$[1: 1]$} & 0,01 & 0,936790 & 6 \\
\hline EM16920 & IAPAR-123 & 68 & 80 & 12 & {$[1: 1]$} & 0,97 & 0,323940 & 6 \\
\hline EM17190 & IAPAR-06 & 60 & 97 & 3 & {$[1: 1]$} & 8,72 & 0,003148 & $6^{*}$ \\
\hline EM173068 & Ambos & 26 & 89 & 45 & {$[3: 1]$} & 0,35 & 0,553703 & 6 \\
\hline EM17400 & Ambos & 45 & 107 & 8 & [3:1] & 1,72 & 0,189783 & 6 \\
\hline EM21122 & Ambos & 32 & 84 & 44 & {$[3: 1]$} & 0,41 & 0,520051 & 6 \\
\hline EM21128 & Ambos & 47 & 111 & 2 & {$[3: 1]$} & 1,90 & 0,168220 & 6 \\
\hline EM23215 & IAPAR-06 & 60 & 54 & 46 & {$[1: 1]$} & 0,32 & 0,574149 & 6 \\
\hline EM24108 & Ambos & 48 & 109 & 3 & {$[3: 1]$} & 2,60 & 0,106806 & 6 \\
\hline PM01254 & IAPAR-123 & 80 & 73 & 7 & {$[1: 1]$} & 0,32 & 0,571451 & 6 \\
\hline PM02108 & Ambos & 29 & 88 & 43 & {$[3: 1]$} & 0,00 & 0,957432 & 6 \\
\hline PM023558 & IAPAR-123 & 61 & 56 & 43 & {$[1: 1]$} & 0,21 & 0,643902 & 6 \\
\hline PM02536 & Ambos & 24 & 93 & 43 & {$[3: 1]$} & 1,26 & 0,262332 & 6 \\
\hline PM03242 & IAPAR-06 & 70 & 90 & 0 & {$[1: 1]$} & 2,50 & 0,113846 & 6 \\
\hline PM06337 & IAPAR-06 & 86 & 73 & 1 & {$[1: 1]$} & 1,06 & 0,302557 & 6 \\
\hline PM0783 & IAPAR-123 & 76 & 84 & 0 & {$[1: 1]$} & 0,40 & 0,527089 & 6 \\
\hline PM10129 & IAPAR-123 & 80 & 80 & 0 & {$[1: 1]$} & 0,00 & 1,000000 & 6 \\
\hline EM01158 & Ambos & 28 & 86 & 46 & {$[3: 1]$} & 0,01 & 0,913879 & 7 \\
\hline EM0168 & IAPAR-123 & 86 & 70 & 4 & {$[1: 1]$} & 1,64 & 0,200185 & 7 \\
\hline EM02132 & Ambos & 37 & 120 & 3 & {$[3: 1]$} & 0,17 & 0,678363 & 7 \\
\hline EM02337 & IAPAR-06 & 73 & 85 & 2 & {$[1: 1]$} & 0,91 & 0,339745 & 7 \\
\hline EM02425 & IAPAR-123 & 70 & 88 & 2 & {$[1: 1]$} & 2,05 & 0,152143 & 7 \\
\hline EM03272 & IAPAR-123 & 83 & 76 & 1 & {$[1: 1]$} & 0,31 & 0,578802 & 7 \\
\hline EM03288 & IAPAR-06 & 78 & 81 & 1 & {$[1: 1]$} & 0,06 & 0,811947 & 7 \\
\hline EM0388 & Ambos & 40 & 119 & 1 & {$[3: 1]$} & 0,00 & 0,963480 & 7 \\
\hline EM0398 & Ambos & 44 & 115 & 1 & {$[3: 1]$} & 0,61 & 0,436347 & 7 \\
\hline EM05150 & Ambos & 27 & 72 & 61 & [3:1] & 0,27 & 0,601508 & 7 \\
\hline EM06113 & Ambos & 60 & 100 & 0 & {$[3: 1]$} & 13,33 & 0,000261 & $7 *$ \\
\hline EM06175 & IAPAR-06 & 80 & 80 & 0 & [1:1] & 0,00 & 1,000000 & 7 \\
\hline EM061940 & Ambos & 32 & 80 & 48 & {$[3: 1]$} & 0,76 & 0,382733 & 7 \\
\hline EM06252 & Ambos & 36 & 121 & 3 & {$[3: 1]$} & 0,36 & 0,549167 & 7 \\
\hline
\end{tabular}


Tabela 15. Segregação dos marcadores AFLP, com o respectivo genitor informativo, número de indivíduos com os fenótipos moleculares observado na progênie, segregação esperada, valor do teste de qui-quadrado $\left(\chi^{2}\right)$, com 1 grau de liberdade, nível de significância e grupo de ligação ao qual a marca foi alocada

\begin{tabular}{|c|c|c|c|c|c|c|c|c|}
\hline \multirow{2}{*}{$\begin{array}{l}\text { Código do } \\
\text { marcador }\end{array}$} & \multirow{2}{*}{$\begin{array}{l}\text { Genitor } \\
\text { informativo }\end{array}$} & \multicolumn{3}{|c|}{ Fenótipos moleculares observados na progênie } & \multirow{2}{*}{$\begin{array}{l}\text { Segregação } \\
\text { esperada }\end{array}$} & \multirow{2}{*}{$\chi^{2}$} & \multirow{2}{*}{ "p-valor" } & \multirow{2}{*}{$\begin{array}{l}\text { Grupo de } \\
\text { ligação }\end{array}$} \\
\hline & & “0” & “1” & “ - “ & & & & \\
\hline EM07236 & IAPAR-06 & 82 & 78 & 0 & {$[1: 1]$} & 0,10 & 0,751830 & 7 \\
\hline EM07314 & Ambos & 28 & 132 & 0 & {$[3: 1]$} & 4,80 & 0,028460 & $7^{*}$ \\
\hline EM07480 & IAPAR-123 & 71 & 87 & 2 & {$[1: 1]$} & 1,62 & 0,203057 & 7 \\
\hline EM0774 & IAPAR-06 & 57 & 54 & 49 & {$[1: 1]$} & 0,08 & 0,775838 & 7 \\
\hline EM08390 & IAPAR-06 & 79 & 80 & 1 & {$[1: 1]$} & 0,01 & 0,936790 & 7 \\
\hline EM08400 & Ambos & 42 & 117 & 1 & {$[3: 1]$} & 0,17 & 0,680280 & 7 \\
\hline EM09187 & IAPAR-123 & 86 & 73 & 1 & {$[1: 1]$} & 1,06 & 0,302557 & 7 \\
\hline EM09360 & IAPAR-123 & 80 & 72 & 8 & {$[1: 1]$} & 0,42 & 0,516412 & 7 \\
\hline EM0975 & Ambos & 33 & 83 & 44 & {$[3: 1]$} & 0,74 & 0,391064 & 7 \\
\hline EM12249 & Ambos & 35 & 81 & 44 & {$[3: 1]$} & 1,66 & 0,198256 & 7 \\
\hline EM12622 & IAPAR-123 & 67 & 83 & 10 & {$[1: 1]$} & 1,71 & 0,191419 & 7 \\
\hline EM13370 & Ambos & 26 & 67 & 67 & [3:1] & 0,43 & 0,510183 & 7 \\
\hline EM1383 & Ambos & 39 & 114 & 7 & {$[3: 1]$} & 0,02 & 0,888638 & 7 \\
\hline EM14142 & Ambos & 28 & 73 & 59 & {$[3: 1]$} & 0,40 & 0,527430 & 7 \\
\hline EM14192 & IAPAR-123 & 88 & 72 & 0 & {$[1: 1]$} & 1,60 & 0,205903 & 7 \\
\hline EM15234 & IAPAR-06 & 78 & 77 & 5 & {$[1: 1]$} & 0,01 & 0,935981 & 7 \\
\hline EM15594 & IAPAR-123 & 88 & 72 & 0 & {$[1: 1]$} & 1,60 & 0,205903 & 7 \\
\hline EM15700 & IAPAR-123 & 71 & 89 & 0 & {$[1: 1]$} & 2,03 & 0,154729 & 7 \\
\hline EM16575 & IAPAR-06 & 81 & 78 & 1 & {$[1: 1]$} & 0,06 & 0,811947 & 7 \\
\hline EM16760 & IAPAR-123 & 88 & 71 & 1 & {$[1: 1]$} & 1,82 & 0,177598 & 7 \\
\hline EM17140 & IAPAR-123 & 87 & 70 & 3 & {$[1: 1]$} & 1,84 & 0,174861 & 7 \\
\hline EM17160 & Ambos & 37 & 120 & 3 & {$[3: 1]$} & 0,17 & 0,678363 & 7 \\
\hline EM17460 & Ambos & 47 & 109 & 4 & {$[3: 1]$} & 2,19 & 0,139087 & 7 \\
\hline EM17475 & IAPAR-123 & 72 & 85 & 3 & {$[1: 1]$} & 1,08 & 0,299497 & 7 \\
\hline EM18305 & IAPAR-06 & 82 & 76 & 2 & {$[1: 1]$} & 0,23 & 0,633124 & 7 \\
\hline EM18363 & IAPAR-06 & 75 & 84 & 1 & {$[1: 1]$} & 0,51 & 0,475384 & 7 \\
\hline EM18463 & Ambos & 39 & 119 & 2 & {$[3: 1]$} & 0,01 & 0,926807 & 7 \\
\hline EM19135 & IAPAR-123 & 83 & 75 & 2 & {$[1: 1]$} & 0,41 & 0,524486 & 7 \\
\hline EM19154 & IAPAR-06 & 69 & 81 & 10 & {$[1: 1]$} & 0,96 & 0,327187 & 7 \\
\hline EM19531 & IAPAR-123 & 73 & 85 & 2 & {$[1: 1]$} & 0,91 & 0,339745 & 7 \\
\hline EM19790 & IAPAR-123 & 79 & 68 & 13 & {$[1: 1]$} & 0,82 & 0,364267 & 7 \\
\hline EM1995 & IAPAR-06 & 76 & 81 & 3 & {$[1: 1]$} & 0,16 & 0,689861 & 7 \\
\hline EM20139 & Ambos & 46 & 111 & 3 & {$[3: 1]$} & 1,55 & 0,213465 & 7 \\
\hline EM21162 & Ambos & 26 & 128 & 6 & {$[3: 1]$} & 5,41 & 0,020007 & $7 *$ \\
\hline EM21184 & Ambos & 44 & 114 & 2 & {$[3: 1]$} & 0,68 & 0,408369 & 7 \\
\hline EM21201 & Ambos & 37 & 120 & 3 & {$[3: 1]$} & 0,17 & 0,678363 & 7 \\
\hline EM22100 & IAPAR-123 & 87 & 73 & 0 & {$[1: 1]$} & 1,23 & 0,268382 & 7 \\
\hline EM22123 & IAPAR-06 & 77 & 83 & 0 & {$[1: 1]$} & 0,23 & 0,635256 & 7 \\
\hline
\end{tabular}


Tabela 15. Segregação dos marcadores AFLP, com o respectivo genitor informativo, número de indivíduos com os fenótipos moleculares observado na progênie, segregação esperada, valor do teste de qui-quadrado $\left(\chi^{2}\right)$, com 1 grau de liberdade, nível de significância e grupo de ligação ao qual a marca foi alocada

\begin{tabular}{|c|c|c|c|c|c|c|c|c|}
\hline \multirow{2}{*}{$\begin{array}{l}\text { Código do } \\
\text { marcador }\end{array}$} & \multirow{2}{*}{$\begin{array}{l}\text { Genitor } \\
\text { informativo }\end{array}$} & \multicolumn{3}{|c|}{ Fenótipos moleculares observados na progênie } & \multirow{2}{*}{$\begin{array}{l}\text { Segregação } \\
\text { esperada }\end{array}$} & \multirow{2}{*}{$\chi^{2}$} & \multirow{2}{*}{ "p-valor" } & \multirow{2}{*}{$\begin{array}{l}\text { Grupo de } \\
\text { ligação }\end{array}$} \\
\hline & & “0” & “1” & “ - “ & & & & \\
\hline EM23111 & IAPAR-123 & 51 & 65 & 44 & {$[1: 1]$} & 1,69 & 0,193647 & 7 \\
\hline EM23324 & Ambos & 33 & 83 & 44 & {$[3: 1]$} & 0,74 & 0,391064 & 7 \\
\hline EM24180 & IAPAR-06 & 74 & 84 & 2 & {$[1: 1]$} & 0,63 & 0,426289 & 7 \\
\hline EM24335 & IAPAR-123 & 87 & 71 & 2 & {$[1: 1]$} & 1,62 & 0,203057 & 7 \\
\hline EM24378 & IAPAR-06 & 74 & 70 & 16 & {$[1: 1]$} & 0,11 & 0,738883 & 7 \\
\hline PM01232 & Ambos & 46 & 104 & 10 & {$[3: 1]$} & 2,57 & 0,108984 & 7 \\
\hline PM02179 & IAPAR-06 & 57 & 59 & 44 & {$[1: 1]$} & 0,03 & 0,852684 & 7 \\
\hline PM02250 & IAPAR-123 & 53 & 64 & 43 & {$[1: 1]$} & 1,03 & 0,309177 & 7 \\
\hline PM0272 & Ambos & 38 & 79 & 43 & {$[3: 1]$} & 3,49 & 0,061740 & 7 \\
\hline PM04108 & IAPAR-123 & 84 & 73 & 3 & {$[1: 1]$} & 0,77 & 0,380000 & 7 \\
\hline PM04132 & Ambos & 40 & 115 & 5 & {$[3: 1]$} & 0,05 & 0,816639 & 7 \\
\hline PM04142 & IAPAR-123 & 84 & 73 & 3 & {$[1: 1]$} & 0,77 & 0,380000 & 7 \\
\hline PM041708 & IAPAR-06 & 55 & 48 & 57 & {$[1: 1]$} & 0,48 & 0,490364 & 7 \\
\hline PM04216 & Ambos & 48 & 104 & 8 & {$[3: 1]$} & 3,51 & 0,061045 & 7 \\
\hline PM0481 & Ambos & 43 & 114 & 3 & [3:1] & 0,48 & 0,489463 & 7 \\
\hline PM05342 & IAPAR-123 & 81 & 77 & 2 & {$[1: 1]$} & 0,10 & 0,750316 & 7 \\
\hline PM06264 & IAPAR-123 & 78 & 81 & 1 & {$[1: 1]$} & 0,06 & 0,811947 & 7 \\
\hline PM07149 & Ambos & 50 & 110 & 0 & {$[3: 1]$} & 3,33 & 0,067889 & 7 \\
\hline PM09160 & Ambos & 61 & 76 & 23 & [3:1] & 27,86 & 0,000000 & $7 * * *$ \\
\hline PM09188 & IAPAR-06 & 87 & 61 & 12 & {$[1: 1]$} & 4,57 & 0,032583 & $7^{*}$ \\
\hline PM10161 & IAPAR-06 & 83 & 74 & 3 & {$[1: 1]$} & 0,52 & 0,472586 & 7 \\
\hline EM012292 & IAPAR-123 & 77 & 71 & 12 & {$[1: 1]$} & 0,24 & 0,621873 & 8 \\
\hline EM03102 & Ambos & 39 & 113 & 8 & {$[3: 1]$} & 0,04 & 0,851412 & 8 \\
\hline EM03291 & Ambos & 40 & 119 & 1 & {$[3: 1]$} & 0,00 & 0,963480 & 8 \\
\hline EM05318 & Ambos & 47 & 113 & 0 & {$[3: 1]$} & 1,63 & 0,201243 & 8 \\
\hline EM06717 & IAPAR-06 & 86 & 73 & 1 & {$[1: 1]$} & 1,06 & 0,302557 & 8 \\
\hline EM0986 & IAPAR-123 & 75 & 79 & 6 & {$[1: 1]$} & 0,10 & 0,747203 & 8 \\
\hline EM11128 & Ambos & 26 & 132 & 2 & {$[3: 1]$} & 6,15 & 0,013127 & $8^{*}$ \\
\hline EM12477 & Ambos & 31 & 108 & 21 & {$[3: 1]$} & 0,54 & 0,462612 & 8 \\
\hline EM16163 & Ambos & 47 & 111 & 2 & {$[3: 1]$} & 1,90 & 0,168220 & 8 \\
\hline EM16165 & Ambos & 45 & 113 & 2 & {$[3: 1]$} & 1,02 & 0,312259 & 8 \\
\hline EM18124 & IAPAR-06 & 85 & 75 & 0 & {$[1: 1]$} & 0,63 & 0,429195 & 8 \\
\hline EM19112 & IAPAR-06 & 76 & 81 & 3 & {$[1: 1]$} & 0,16 & 0,689861 & 8 \\
\hline EM21550 & IAPAR-123 & 84 & 75 & 1 & {$[1: 1]$} & 0,51 & 0,475384 & 8 \\
\hline EM22110 & IAPAR-06 & 82 & 76 & 2 & {$[1: 1]$} & 0,23 & 0,633124 & 8 \\
\hline EM22560 & IAPAR-06 & 71 & 88 & 1 & {$[1: 1]$} & 1,82 & 0,177598 & 8 \\
\hline EM24160 & IAPAR-123 & 86 & 73 & 1 & {$[1: 1]$} & 1,06 & 0,302557 & 8 \\
\hline PM03245 & IAPAR-123 & 71 & 86 & 3 & {$[1: 1]$} & 1,43 & 0,231256 & 8 \\
\hline
\end{tabular}


Tabela 15. Segregação dos marcadores AFLP, com o respectivo genitor informativo, número de indivíduos com os fenótipos moleculares observado na progênie, segregação esperada, valor do teste de qui-quadrado $\left(\chi^{2}\right)$, com 1 grau de liberdade, nível de significância e grupo de ligação ao qual a marca foi alocada

\begin{tabular}{|c|c|c|c|c|c|c|c|c|}
\hline \multirow{2}{*}{$\begin{array}{l}\text { Código do } \\
\text { marcador }\end{array}$} & \multirow{2}{*}{$\begin{array}{l}\text { Genitor } \\
\text { informativo }\end{array}$} & \multicolumn{3}{|c|}{ Fenótipos moleculares observados na progênie } & \multirow{2}{*}{$\begin{array}{l}\text { Segregação } \\
\text { esperada }\end{array}$} & \multirow{2}{*}{$\chi^{2}$} & \multirow{2}{*}{ "p-valor" } & \multirow{2}{*}{$\begin{array}{l}\text { Grupo de } \\
\text { ligação }\end{array}$} \\
\hline & & “0” & “1” & “ _ “ & & & & \\
\hline PM06242 & IAPAR-123 & 66 & 45 & 49 & {$[1: 1]$} & 3,97 & 0,046236 & $8^{*}$ \\
\hline PM06244 & IAPAR-123 & 60 & 53 & 47 & {$[1: 1]$} & 0,43 & 0,510214 & 8 \\
\hline PM07222 & IAPAR-123 & 87 & 73 & 0 & {$[1: 1]$} & 1,23 & 0,268382 & 8 \\
\hline PM08302 & IAPAR-123 & 61 & 55 & 44 & {$[1: 1]$} & 0,31 & 0,577469 & 8 \\
\hline EM01236 & IAPAR-06 & 81 & 74 & 5 & {$[1: 1]$} & 0,32 & 0,573943 & - \\
\hline EM01290 & IAPAR-06 & 63 & 47 & 50 & {$[1: 1]$} & 2,33 & 0,127124 & - \\
\hline EM0477 & Ambos & 29 & 87 & 44 & {$[3: 1]$} & 0,00 & 1,000000 & - \\
\hline EM08115 & Ambos & 20 & 139 & 1 & [3:1] & 13,08 & 0,000298 & -* \\
\hline EM09410 & Ambos & 43 & 110 & 7 & {$[3: 1]$} & 0,79 & 0,375163 & - \\
\hline EM13277 & IAPAR-123 & 77 & 79 & 4 & {$[1: 1]$} & 0,03 & 0,872780 & - \\
\hline EM15125 & Ambos & 23 & 89 & 48 & {$[3: 1]$} & 1,19 & 0,275234 & - \\
\hline EM15213 & IAPAR-06 & 68 & 87 & 5 & {$[1: 1]$} & 2,33 & 0,126981 & - \\
\hline EM1593 & Ambos & 29 & 79 & 52 & {$[3: 1]$} & 0,20 & 0,656721 & - \\
\hline EM182543 & Ambos & 24 & 84 & 52 & {$[3: 1]$} & 0,44 & 0,504985 & - \\
\hline EM2160 & Ambos & 20 & 96 & 44 & [3:1] & 3,72 & 0,053631 & - \\
\hline EM2181 & IAPAR-06 & 73 & 86 & 1 & {$[1: 1]$} & 1,06 & 0,302557 & - \\
\hline EM23186 & Ambos & 33 & 83 & 44 & [3:1] & 0,74 & 0,391064 & - \\
\hline PM01262 & Ambos & 20 & 40 & 100 & [3:1] & 2,22 & 0,136037 & - \\
\hline PM02262 & IAPAR-06 & 63 & 53 & 44 & {$[1: 1]$} & 0,86 & 0,353160 & - \\
\hline PM02282 & Ambos & 10 & 56 & 94 & {$[3: 1]$} & 3,41 & 0,064640 & - \\
\hline PM02286 & Ambos & 50 & 64 & 46 & {$[3: 1]$} & 21,63 & 0,000003 & $-* * *$ \\
\hline PM03104 & Ambos & 28 & 67 & 65 & {$[3: 1]$} & 1,01 & 0,313938 & - \\
\hline PM0381 & Ambos & 42 & 114 & 4 & [3:1] & 0,31 & 0,579100 & - \\
\hline PM04277 & Ambos & 41 & 112 & 7 & [3:1] & 0,26 & 0,607646 & - \\
\hline PM05114 & Ambos & 40 & 118 & 2 & {$[3: 1]$} & 0,01 & 0,926807 & - \\
\hline PM06140 & Ambos & 46 & 111 & 3 & [3:1] & 1,55 & 0,213465 & - \\
\hline РM09317 & IAPAR-123 & 47 & 55 & 58 & {$[1: 1]$} & 0,63 & 0,428292 & - \\
\hline
\end{tabular}

* marcadores cuja segregação mostrou distorção da proporção esperada (5\% de probabilidade);

*** marcadores cuja segregação mostrou distorção após correção por Bonferroni (Rice, 1989)

Todas as marcas foram testadas quanto à possível associação (ligação genética) com os fenótipos relativos à bacteriose. Este tipo de avaliação não requer a construção de um mapa genético. A associação significativa entre uma marca simples e o fenótipo da característica em estudo através de uma análise de variância é interpretada como uma indicação da presença de um QTL ligado à marca em questão. Como estes testes 
consideram somente uma marca de cada vez, eles não requerem qualquer informação sobre os locos adjacentes, pois até esse ponto não há a necessidade do marcador estar alocado a um grupo de ligação.

Considerando que foi observado efeito do posicionamento das folhas, os testes de marcas simples foram realizados com base nas médias ajustadas dos dados transformados para cada situação, ou seja, o respectivo experimento, a data de avaliação e a posição das folhas. Os dados fenotípicos usados nessas análises estão apresentados na Tabela 16.

Tabela 16. Dados fenotípicos usados nas análises de QRL, considerando as médias ajustadas, com transformação logarítmica, o experimento, a data de avaliação e a posição das folhas ${ }^{1 /}$

\begin{tabular}{|c|c|c|c|c|c|c|c|c|c|c|c|c|c|}
\hline \multirow{2}{*}{ Indivíduo } & \multicolumn{7}{|c|}{ Primeiro Experimento } & \multicolumn{6}{|c|}{ Segundo Experimento } \\
\hline & DT1 & DT2 & DT3 & DT4 & P1 & P2 & P3 & 2DT1 & 2DT2 & 2DT3 & 2P1 & $2 \mathrm{P} 2$ & 2P3 \\
\hline $1(3)$ & 0,713 & 0,982 & 1,152 & 1,296 & 0,671 & 0,803 & 0,813 & 0,585 & 0,793 & 1,009 & 0,572 & 0,612 & 0,607 \\
\hline $2(1)$ & 0,577 & 0,840 & 1,047 & 1,250 & 0,569 & 0,721 & 0,735 & 0,429 & 0,627 & 0,761 & 0,427 & 0,343 & 0,470 \\
\hline $2(3)$ & 0,689 & 0,980 & 1,192 & 1,374 & 0,813 & 0,802 & 0,761 & 0,606 & 0,855 & 1,067 & 0,634 & 0,684 & 0,627 \\
\hline $2(5)$ & 0,563 & 0,796 & 0,944 & 1,079 & 0,567 & 0,603 & 0,550 & 0,568 & 0,765 & 0,938 & 0,634 & 0,617 & 0,406 \\
\hline $2(7)$ & 0,715 & 0,957 & 1,024 & 1,138 & 0,622 & 0,634 & 0,646 & 0,338 & 0,494 & 0,656 & 0,305 & 0,341 & 0,383 \\
\hline $3(6)$ & 0,724 & 1,047 & 1,248 & 1,473 & 0,922 & 0,880 & 0,864 & 0,761 & 1,034 & 1,285 & 0,856 & 0,805 & 0,838 \\
\hline $3(10)$ & 0,530 & 0,701 & 0,861 & 1,064 & 0,529 & 0,563 & 0,547 & 0,472 & 0,770 & 0,927 & 0,568 & 0,506 & 0,524 \\
\hline $3(12)$ & 0,597 & 0,895 & 1,117 & 1,298 & 0,718 & 0,753 & 0,778 & 0,546 & 0,760 & 0,993 & 0,532 & 0,551 & 0,672 \\
\hline $3(13)$ & 0,729 & 0,954 & 1,165 & 1,337 & 0,843 & 0,725 & 0,792 & 0,478 & 0,702 & 0,955 & 0,501 & 0,553 & 0,604 \\
\hline $4(2)$ & 0,562 & 0,758 & 1,009 & 1,172 & 0,712 & 0,639 & 0,596 & 0,423 & 0,620 & 0,763 & 0,332 & 0,409 & 0,491 \\
\hline $4(5)$ & 0,608 & 0,811 & 1,011 & 1,228 & 0,652 & 0,620 & 0,796 & 0,546 & 0,743 & 0,987 & 0,495 & 0,541 & 0,695 \\
\hline $4(7)$ & 0,665 & 0,922 & 1,090 & 1,284 & 0,681 & 0,792 & 0,752 & 0,452 & 0,713 & 0,960 & 0,553 & 0,501 & 0,589 \\
\hline $5(2)$ & 0,557 & 0,819 & 0,962 & 1,075 & 0,555 & 0,576 & 0,748 & 0,494 & 0,726 & 0,885 & 0,431 & 0,549 & 0,517 \\
\hline $5(4)$ & 0,705 & 0,982 & 1,205 & 1,413 & 0,843 & 0,876 & 0,823 & 0,600 & 0,823 & 1,047 & 0,639 & 0,636 & 0,630 \\
\hline $5(5)$ & 0,572 & 0,776 & 0,936 & 1,097 & 0,600 & 0,584 & 0,603 & 0,416 & 0,607 & 0,789 & 0,422 & 0,449 & 0,410 \\
\hline $6(1)$ & 0,521 & 0,858 & 0,961 & 1,056 & 0,482 & 0,518 & 0,602 & 0,490 & 0,615 & 0,772 & 0,490 & 0,332 & 0,454 \\
\hline $6(3)$ & 0,562 & 0,771 & 0,949 & 1,072 & 0,603 & 0,592 & 0,549 & 0,474 & 0,709 & 0,909 & 0,429 & 0,535 & 0,620 \\
\hline $7(1)$ & 0,557 & 0,821 & 1,038 & 1,231 & 0,704 & 0,714 & 0,671 & 0,592 & 0,794 & 1,014 & 0,546 & 0,557 & 0,703 \\
\hline $8(1)$ & 0,537 & 0,813 & 0,907 & 1,083 & 0,578 & 0,645 & 0,535 & 0,381 & 0,550 & 0,777 & 0,345 & 0,441 & 0,469 \\
\hline $8(2)$ & 0,633 & 0,825 & 1,021 & 1,222 & 0,669 & 0,715 & 0,703 & 0,476 & 0,728 & 0,947 & 0,513 & 0,558 & 0,562 \\
\hline $8(4)$ & 0,583 & 0,801 & 0,972 & 1,150 & 0,674 & 0,586 & 0,597 & 0,452 & 0,642 & 0,785 & 0,492 & 0,325 & 0,457 \\
\hline $8(8)$ & 0,517 & 0,788 & 0,969 & 1,161 & 0,702 & 0,583 & 0,648 & 0,466 & 0,672 & 0,860 & 0,491 & 0,540 & 0,485 \\
\hline $8(10)$ & 0,676 & 0,883 & 1,095 & 1,269 & 0,747 & 0,717 & 0,737 & 0,527 & 0,748 & 0,933 & 0,575 & 0,495 & 0,542 \\
\hline $8(12)$ & 0,522 & 0,777 & 0,917 & 1,093 & 0,569 & 0,622 & 0,601 & 0,495 & 0,715 & 0,889 & 0,556 & 0,474 & 0,493 \\
\hline $8(13)$ & 0,562 & 0,859 & 1,090 & 1,306 & 0,674 & 0,765 & 0,781 & 0,608 & 0,894 & 1,067 & 0,650 & 0,603 & 0,770 \\
\hline $9(1)$ & 0,617 & 0,889 & 1,094 & 1,250 & 0,647 & 0,787 & 0,746 & 0,539 & 0,816 & 1,047 & 0,790 & 0,488 & 0,599 \\
\hline $9(3)$ & 0,692 & 0,890 & 1,053 & 1,222 & 0,687 & 0,707 & 0,690 & 0,453 & 0,658 & 0,924 & 0,539 & 0,541 & 0,482 \\
\hline $9(4)$ & 0,539 & 0,817 & 1,054 & 1,210 & 0,681 & 0,713 & 0,691 & 0,565 & 0,771 & 1,000 & 0,580 & 0,540 & 0,647 \\
\hline
\end{tabular}


Tabela 16. Dados fenotípicos usados nas análises de QRL, considerando as médias ajustadas, com transformação logarítmica, o experimento, a data de avaliação e a posição das folhas ${ }^{1 /}$

\begin{tabular}{|c|c|c|c|c|c|c|c|c|c|c|c|c|c|}
\hline \multirow{2}{*}{ Indivíduo } & \multicolumn{7}{|c|}{ Primeiro Experimento } & \multicolumn{6}{|c|}{ Segundo Experimento } \\
\hline & DT1 & DT2 & DT3 & DT4 & P1 & P2 & P3 & 2DT1 & 2DT2 & 2DT3 & 2P1 & $2 \mathrm{P} 2$ & $2 \mathrm{P} 3$ \\
\hline 10(5) & 0,694 & 0,914 & 1,154 & 1,328 & 0,742 & 0,745 & 0,826 & 0,610 & 0,864 & 1,062 & 0,731 & 0,622 & 0,641 \\
\hline 11(1) & 0,658 & 0,926 & 1,148 & 1,342 & 0,790 & 0,790 & 0,783 & 0,782 & 1,033 & & ,843 & 0,836 & 0,810 \\
\hline $12(2)$ & 546 & 0,791 & 0,903 & 1,062 & 0,522 & 0,632 & 0,587 & 0,447 & 0,653 & 0,829 & 0,484 & 0,423 & 0,483 \\
\hline $12(6)$ & 0,584 & 0,815 & 1,009 & 1,155 & 0,636 & 0,692 & 0,637 & 0,514 & 0,739 & & 0,623 & 0,613 & 0,575 \\
\hline 12(9) & 0,636 & 0,834 & 0,956 & 1,109 & 0,645 & 0,629 & & 0,466 & 0,645 & 0,940 & 0,435 & 0,479 & 0,529 \\
\hline $12(10)$ & 0,556 & 0,814 & 0,987 & 1,218 & 0,741 & 0,648 & 0,667 & 0,516 & 0,761 & 0,988 & 0,567 & 0,652 & 0,542 \\
\hline $12(13)$ & 0,666 & 0,872 & 1,053 & 1,248 & 0,672 & 0,682 & 0,818 & 0,703 & 0,899 & 1,077 & 0,762 & 0,579 & 0,652 \\
\hline $12(15)$ & 0,560 & 0,786 & 0,928 & 1,074 & 0,652 & 0,629 & 0,488 & 0,492 & 0,697 & 0,858 & 0,501 & 0,476 & 0,429 \\
\hline $12(17)$ & 0,632 & 0,827 & 0,958 & 1,081 & 0,603 & 0,603 & 0,570 & 0,382 & 0,613 & 0,788 &, 458 & 0,396 & 0,410 \\
\hline $12(19)$ & 0,698 & 0,950 & 1,140 & 1,326 & 0,750 & 0,808 & 0,823 & 0,654 & 0,864 & 1,115 & 0,734 & 0,625 & 0,694 \\
\hline $12(20)$ & 0,632 & 0,894 & 1,075 & 1,230 & 0,600 & 0,767 & 0,743 & 0,519 & 0,719 & 1,051 & 0,601 & 0,560 & 0,665 \\
\hline $12(23)$ & 668 & 0,863 & 1,022 & 1,115 & 0,631 & 0,640 & & 0,476 & 0,702 & 0,854 & 0,480 & 0,474 & 0,573 \\
\hline 13(3) & 0,670 & 0,951 & 1,169 & 1,358 & 0,746 & 0,806 & 0,8 & 0,672 & 0,905 & 1,148 & 0,728 & 0,691 & 0,730 \\
\hline 13(8) & 0,607 & 0,752 & 0,958 & 1,103 & 0,631 & 0,593 & & 0,599 & 0,907 & 1,115 & 0,739 & 0,711 & 0,631 \\
\hline 13(9) & 0,758 & 1,054 & 1,231 & 1,455 & 0,921 & 0,857 & & 0,813 & 1,050 & 1,285 & 0,856 & 0,772 & 0,858 \\
\hline $14(1)$ & 0,719 & 1,033 & 1,281 & 1,460 & 0,885 & 0,898 & 0,892 & 0,651 & 0,894 & 1,138 & 0,740 & 0,663 & 0,706 \\
\hline $15(2)$ & 0,584 & 0,851 & 1,020 & 1,220 & 0,659 & 0,617 & 0,7 & 0,439 & 0,711 & 0,990 & 0,566 & 0,530 & 0,599 \\
\hline $17(1)$ & 0,645 & 0,889 & 1,125 & 1,341 & 0,785 & 0,783 & 0,7 & 0,527 & 0,741 & 0,960 & 0,463 & 0,604 & 0,585 \\
\hline $17(2)$ & 0,535 & 0,698 & 0,847 & 0,988 & 0,564 & 0,512 & & 595 & 0,834 & & 87 & 0,688 & 0,710 \\
\hline $17(3)$ & 0,692 & 0,971 & 1,140 & 1,368 & 0,812 & 0,765 & & 0,462 & 0,656 & 901 & & 528 & 0,515 \\
\hline $17(4)$ & 0,782 & 1,009 & 1,192 & 1,344 & 0,742 & 0,7 & 0,8 & 0,609 & 0,804 & 0,994 & 69 & 0,586 & 0,570 \\
\hline $17(6)$ & 0,541 & 0,822 & 0,974 & 1,142 & 0,651 & 0,636 & & 0,485 & 0,700 & 0,898 & 0,510 & 0,453 & 0,581 \\
\hline $17(7)$ & 0,522 & 0,766 & 0,935 & 1,099 & 0,608 & 0,555 & & 0,455 & 0,566 & 0,820 & 0,362 & 0,445 & 0,497 \\
\hline $17(8)$ & 0,630 & 0,845 & 1,0 & 1,211 & 0,770 & 0,674 & & 0,551 & 0,843 & 1,013 & 0,585 & 0,591 & 0,646 \\
\hline $17(11)$ & 0,645 & 0,825 & 0,955 & 1,077 & 0,510 & 0,549 & & 0,618 & 0,877 & & & 33 & 0,658 \\
\hline $17(15)$ & 0,607 & 0,818 & & 1,090 & & & & & 0,740 & & & 0,548 & 0,483 \\
\hline $17(17)$ & 0,688 & 0,964 & 1,186 & 1,409 & 0,767 & 0,815 & 0,926 & 0,692 & 0,926 & 1,168 & 0,829 & 0,817 & 0,574 \\
\hline $17(18)$ & 0,566 & 0,844 & 0,904 & 1,036 & 0,585 & 0,602 & & 0,567 & 0,801 & 0,980 & 0,4 & 0,649 & 0,662 \\
\hline $17(22)$ & 0,520 & 0,703 & 0,806 & 0,959 & 0,477 & 0,432 & 0,621 & 0,328 & 0,568 & 0,850 & 0,492 & 0,388 & 0,532 \\
\hline $17(23)$ & 0,624 & 0,806 & & 1,121 & & & & & 0,620 & & & & 0,403 \\
\hline $17(24)$ & 0,633 & 0,845 & 1,063 & 1,275 & 0,682 & 0,743 & 0,764 & 0,524 & 0,751 & 0,981 & 0,580 & 0,553 & 0,592 \\
\hline $17(26)$ & 0,615 & 0,889 & 1,054 & 1,201 & & & & & 0,705 & & & 0,447 & 0,652 \\
\hline $17(28)$ & 0,587 & 0,795 & 0,975 & 1,161 & 0,606 & 0,715 & 0,655 & 0,536 & 0,736 & 0,946 & 0,511 & 0,489 & 0,636 \\
\hline $17(29)$ & 0,558 & 0,696 & 0,853 & 1,011 & 0,533 & 0,559 & & 0,364 & 0,573 & 0,773 & 0,462 & 0,486 & 0,313 \\
\hline $17(30)$ & 0,568 & 0,854 & 1,024 & 1,193 & 0,671 & 0,677 & 0,684 & 0,485 & 0,712 & 0,973 & 0,678 & 0,540 & 0,486 \\
\hline $17(31)$ & 0,685 & 0,892 & 1,045 & 1,221 & 0,677 & 0,686 & & 0,521 & 0,779 & 1,027 & 0,580 & 0,595 & 0,670 \\
\hline $17(33)$ & 0,744 & 1,029 & 1,234 & 1,422 & 0,806 & 0,895 & & 0,489 & 0,742 & 1,035 & 0,572 & 0,639 & 0,614 \\
\hline $17(34)$ & 0,649 & 0,938 & 1,107 & 1,297 & 0,728 & 0,757 & 0,797 & 0,665 & 0,951 & 1,157 & 0,832 & 0,720 & 0,640 \\
\hline $17(35)$ & 0,745 & 0,990 & 1,183 & 1,333 & 0,733 & 0,820 & 0,834 & 0,615 & 0,934 & 1,221 & 0,707 & 0,751 & 0,776 \\
\hline $17(36)$ & 0,651 & 0,930 & 1,084 & 1,288 & 0,716 & 0,787 & 0,742 & 0,620 & 0,875 & 1,126 & 0,743 & 0,704 & 0,688 \\
\hline $17(37)$ & 0,565 & 0,772 & 0,926 & 1,111 & 0,543 & 0,621 & 0,661 & 0,381 & 0,574 & 0,701 & 0,269 & 0,395 & 0,438 \\
\hline $17(38)$ & 0,562 & 0,831 & 0,980 & 1,107 & 0,575 & 0,592 & 0,654 & 0,379 & 0,641 & 0,857 & 0,429 & 0,491 & 0,494 \\
\hline & & 0,608 & 0,658 & 0,919 & 0,802 & & & & 0,797 & 1,024 & 0,593 & 0,562 & 0,596 \\
\hline $17(40)$ & 0,508 & 0,802 & 0,964 & 1,152 & 0,633 & 0,648 & 0,634 & 0,489 & 0,701 & 0,921 & 0,517 & 0,525 & 0,559 \\
\hline $17(41)$ & 0,663 & 0,831 & 1,005 & 1,156 & 0,529 & 0,699 & 0,701 & 0,403 & 0,493 & 0,790 & 0,289 & 0,497 & 0,441 \\
\hline
\end{tabular}


Tabela 16. Dados fenotípicos usados nas análises de QRL, considerando as médias ajustadas, com transformação logarítmica, o experimento, a data de avaliação e a posição das folhas ${ }^{1 /}$

\begin{tabular}{|c|c|c|c|c|c|c|c|c|c|c|c|c|c|}
\hline \multirow{2}{*}{ Indivíduo } & \multicolumn{7}{|c|}{ Primeiro Experimento } & \multicolumn{6}{|c|}{ Segundo Experimento } \\
\hline & DT1 & DT2 & DT3 & DT4 & P1 & P2 & P3 & 2DT1 & 2DT2 & 2DT3 & $2 \mathrm{P} 1$ & $2 \mathrm{P} 2$ & $2 \mathrm{P} 3$ \\
\hline $17(42)$ & 0,621 & 0,834 & 1,002 & 1,201 & 0,726 & 0,678 & 0,636 & 0,445 & 0,644 & 0,842 & 0,475 & 0,435 & 0,564 \\
\hline $17(43)$ & 0,813 & 1,114 & 1,307 & 1,479 & 0,923 & 0,839 & 0,982 & 0,657 & 0,958 & 1,186 & 0,751 & 0,727 & 0,771 \\
\hline $18(2)$ & 0,643 & 0,899 & 1,117 & 1,328 & 0,787 & 0,728 & 0,802 & 0,529 & 0,743 & 0,947 & 0,475 & 0,568 & 0,614 \\
\hline 18(5) & 0,568 & 0,855 & 1,034 & 1,215 & 0,747 & 0,688 & 0,652 & 0,398 & 0,634 & 0,882 & 0,455 & 0,507 & 0,499 \\
\hline 18(7) & 0,593 & 0,788 & 0,987 & 1,125 & 0,549 & 0,586 & 0,720 & 0,465 & 0,729 & 0,943 & 0,567 & 0,520 & 0,539 \\
\hline 19(1) & 0,805 & 1,078 & 1,275 & 1,460 & 0,831 & 0,869 & 0,978 & 0,674 & 0,904 & 1,123 & 0,677 & 0,724 & 0,688 \\
\hline 20(1) & 0,593 & 0,781 & 1,031 & 1,142 & 0,660 & 0,579 & 0,692 & 0,607 & 0,837 & 1,097 & 0,644 & 0,644 & 0,702 \\
\hline $21(1)$ & 0,570 & 0,777 & 0,965 & 1,109 & 0,634 & 0,620 & 0,592 & 0,680 & 0,899 & 1,086 & 0,650 & 0,593 & 0,735 \\
\hline 21(5) & 0,594 & 0,878 & 1,110 & 1,306 & 0,755 & 0,806 & 0,694 & 0,565 & 0,762 & 0,933 & 0,473 & 0,573 & 0,591 \\
\hline III(2) & 0,641 & 0,888 & 1,071 & 1,262 & 0,691 & 0,706 & 0,778 & 0,500 & 0,752 & 0,941 & 0,537 & 0,493 & 0,625 \\
\hline III(3) & 0,621 & 0,867 & 1,079 & 1,296 & 0,671 & 0,792 & 0,771 & 0,601 & 0,838 & 1,007 & 0,558 & 0,664 & 0,601 \\
\hline III(4) & 0,686 & 0,938 & 1,114 & 1,285 & 0,754 & 0,787 & 0,753 & 0,433 & 0,736 & 0,978 & 0,541 & 0,594 & 0,550 \\
\hline III(5) & 0,619 & 0,808 & 1,006 & 1,193 & 0,712 & 0,672 & 0,615 & 0,415 & 0,641 & 0,855 & 0,423 & 0,540 & 0,455 \\
\hline III(6) & 0,553 & 0,816 & 1,021 & 1,161 & 0,617 & 0,595 & 0,695 & 0,553 & 0,807 & 0,950 & 0,550 & 0,505 & 0,619 \\
\hline $\operatorname{III}(7)$ & 0,505 & 0,725 & 0,892 & 1,114 & 0,647 & 0,576 & 0,581 & 0,432 & 0,680 & 0,914 & 0,380 & 0,568 & 0,602 \\
\hline III(8) & 0,575 & 0,771 & 0,952 & 1,151 & 0,603 & 0,634 & 0,649 & 0,506 & 0,795 & 1,050 & 0,646 & 0,559 & 0,676 \\
\hline III(10) & 0,675 & 0,936 & 1,111 & 1,299 & 0,734 & 0,694 & 0,851 & 0,578 & 0,780 & 0,969 & 0,620 & 0,457 & 0,643 \\
\hline III(11) & 0,624 & 0,852 & 1,033 & 1,210 & 0,623 & 0,691 & 0,709 & 0,531 & 0,739 & 0,977 & 0,605 & 0,548 & 0,556 \\
\hline III(12) & 0,641 & 0,904 & 1,102 & 1,303 & 0,786 & 0,745 & 0,720 & 0,623 & 0,860 & 1,134 & 0,725 & 0,651 & 0,688 \\
\hline III(13) & 0,630 & 0,886 & 1,079 & 1,244 & 0,747 & 0,678 & 0,717 & 0,566 & 0,820 & 1,066 & 0,677 & 0,638 & 0,626 \\
\hline III(16) & 0,587 & 0,812 & 1,030 & 1,192 & 0,595 & 0,698 & 0,711 & 0,672 & 0,836 & 0,986 & 0,588 & 0,518 & 0,612 \\
\hline III(17) & 0,599 & 0,861 & 1,036 & 1,230 & 0,666 & 0,743 & 0,682 & 0,566 & 0,880 & 1,118 & 0,672 & 0,678 & 0,693 \\
\hline III(18) & 0,524 & 0,828 & 0,999 & 1,134 & 0,479 & 0,677 & 0,763 & 0,467 & 0,678 & 0,817 & 0,484 & 0,417 & 0,484 \\
\hline$X V(2)$ & 0,606 & 0,862 & 1,088 & 1,231 & 0,652 & 0,652 & 0,799 & 0,444 & 0,708 & 0,886 & 0,471 & 0,485 & 0,540 \\
\hline XV(4) & 0,518 & 0,721 & 0,940 & 1,015 & 0,579 & 0,597 & 0,520 & 0,450 & 0,673 & 0,906 & 0,448 & 0,583 & 0,510 \\
\hline XV(5) & 0,634 & 0,830 & 0,981 & 1,107 & 0,484 & 0,704 & 0,654 & 0,501 & 0,763 & 0,988 & 0,598 & 0,527 & 0,673 \\
\hline XV(7) & 0,644 & 0,886 & 1,080 & 1,265 & 0,731 & 0,748 & 0,695 & 0,547 & 0,782 & 0,958 & 0,434 & 0,577 & 0,672 \\
\hline XV(8) & 0,533 & 0,783 & 0,982 & 1,158 & 0,637 & 0,671 & 0,630 & 0,422 & 0,675 & 0,932 & 0,524 & 0,519 & 0,532 \\
\hline$X V(10)$ & 0,563 & 0,804 & 0,988 & 1,130 & 0,602 & 0,588 & 0,687 & 0,612 & 0,878 & 1,034 & 0,625 & 0,627 & 0,604 \\
\hline $\mathrm{XV}(11)$ & 0,619 & 0,860 & 1,076 & 1,260 & 0,764 & 0,679 & 0,718 & 0,562 & 0,774 & 1,001 & 0,606 & 0,607 & 0,641 \\
\hline$X V(12)$ & 0,642 & 0,828 & 0,974 & 1,102 & 0,509 & 0,720 & 0,615 & 0,611 & 0,897 & 1,142 & 0,674 & 0,693 & 0,758 \\
\hline
\end{tabular}

No intuito de verificar as respostas dos testes de marcas simples, considerando os dados tomados a cada dois dias e o efeito das posições das folhas, foram considerados, somente para essa finalidade, todos os testes com p-valor inferior a $10 \%$ como significativos. A idéia foi verificar o comportamento das marcas na presença das interações significativas entre genótipo x data de avaliação e genótipo x posição da folha inoculada. O resultados de cada marca estão apresentados mais adiante (Tabela 20). 


\subsection{Construção dos mapas de ligação}

Neste estudo, foram utilizadas 114 (30,9\%) marcas informativas oriundas do genitor IAPAR-06, 139 (37,7\%) marcas informativas do genitor IAPAR-123 e 116 $(31,4 \%)$ marcadores bi-parentais. Como esperado, a proporção elevada de locos biparentais demonstra que os dois acessos são mais próximos geneticamante, comparativamente a cruzamentos interespecíficos, como o realizado por Yin et al. (2001) que verificaram haver somente $2 \%$ de marcadores RAPD bi-parentais no cruzamento entre Populus adenopoda e P. alba.

O programa computacional JoinMap permite a construção de mapas de ligação utilizando a mistura dos marcadores de segregação 1:1 com os de segregação 3:1. O resultado dos agrupamentos dos marcadores é visualizado em um tipo de "árvore”, com ramificações. Nesta “árvore” procurou-se obter os nove grupos de ligação correspondentes ao número haplóide de cromossomos da espécie (n=9). Entretanto, foram obtidos oito grupos de ligação, envolvendo 346 (93,8\%) marcadores. Portanto, somente 23 (6,2\%) dos marcadores não foram alocados (Figura 23). Nesta figura, os grupos estão indicados por setas. As setas direcionadas para direita indicam um determinado nó de origem dos grupos. Estes grupos foram formados a partir da fusão das ramificações adjacentes ao respectivo nó. As ramificações fusionadas a partir de cada nó estão indicadas por pequenas estrelas pretas, logo embaixo de cada seta. As setas direcionadas à esquerda representam determinado grupo formado sem a necessidade da fusão de ramificações. 


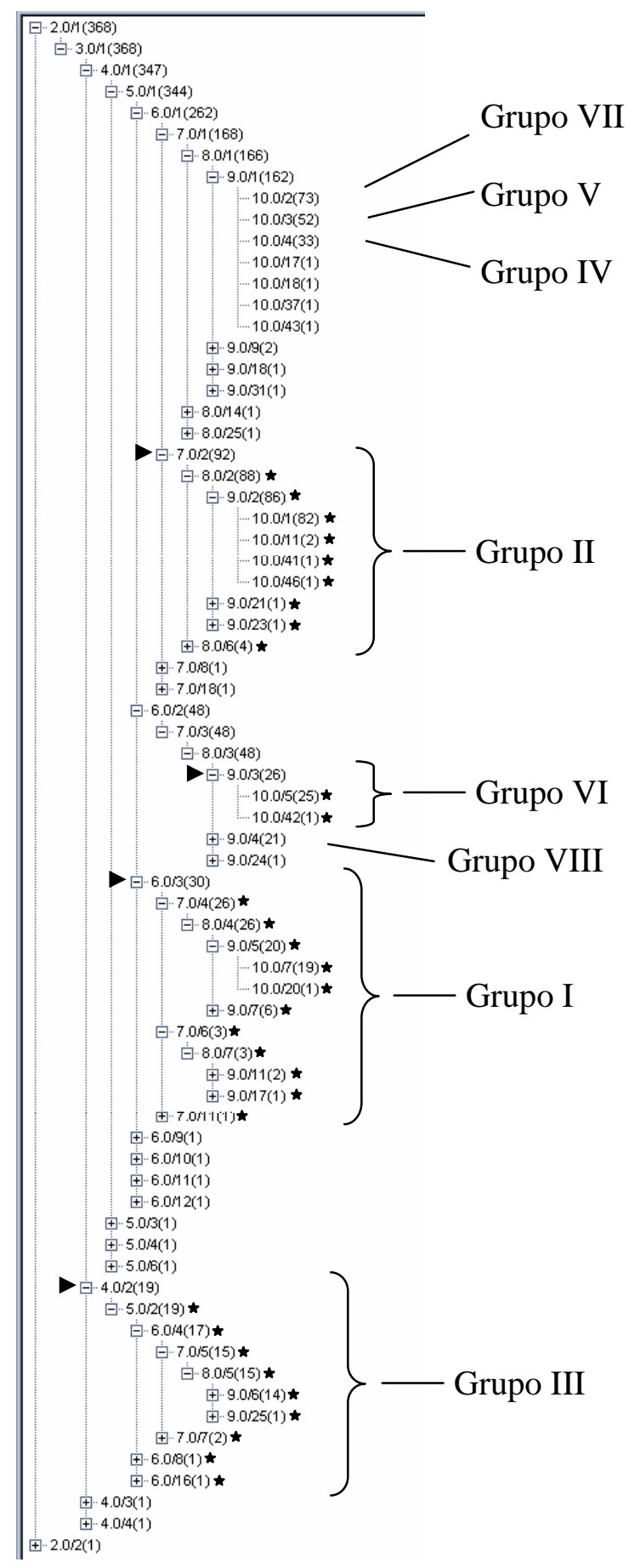

Figura 23 - Formação dos grupos de ligação usando o programa computacional JoinMap 
De acordo com esse procedimento de agrupamento dos marcadores, realizado pelo JoinMap, os grupos de ligação foram formados com razões de verossimilhança (LOD) distintas. O Grupo III foi formado com um LOD 4, o Grupo I com LOD 6, o Grupo II com LOD 7, os Grupos VI e VIII com LOD 9 e os Grupos IV, V e VII com LOD 10. Estes valores para a realização dos agrupamentos são muito rigorosos. Caso fosse adotado um LOD 9, como sendo o máximo, por exemplo, os grupos IV, V e VII seriam integrados em um só. Portanto, o número total de grupos seria ainda menor.

Esperava-se que fossem formados nove grupos correspondentes ao número de pares de cromossomos homólogos de maracujá-amarelo. No trabalho realizado por Lopes (2003), com 117 indivíduos, nove grupos para cada genitor foram gerados pelo programa computacional Mapmaker. Vale relatar que dois dos grupos formados (IAPAR-06) continham apenas três marcadores. O aumento do número de indivíduos para 160 pode ter favorecido a detecção de outras recombinações ou de um número maior entre certos pares de locos. A falta de correspondência com o número haplóide refere-se, possivelmente, à necessidade de se utilizar novos marcadores para análise da população de mapeamento.

Neste estudo, foi verificado que todos os grupos formados possuíam pelo menos quatro marcadores bi-parentais. Foram obtidos quatro marcadores bi-parentais para o Grupo I e Grupo III, seis para o Grupo IV, sete para o Grupo VIII, nove para o Grupo VI, 17 para o Grupo V, 23 para o Grupo II e 30 marcadores bi-parentais para o Grupo VII. Segundo Atienza et al. (2002) para a integração dos grupos homólogos, seriam necessários, pelo menos, dois marcadores bi-parentais segregando em cada grupo de ligação. A princípio, verificou-se não haver restrições para a realização dessa integração em maracujá-amarelo.

Atienza et al (2002) ao construírem um mapa genético para Miscanthus sinensis, relatam que utilizaram um determinado rigor para estabelecer a ligação e a ordem dos marcadores nos grupos. Foram utilizados os parâmetros LOD 4,0 para se considerar ligação entre as marcas, a ordem dos locos foi estimada com um LOD mínimo de 1,0 e o limiar de recombinação como sendo 0,40 cM. Entretanto, para um determinado grupo de 
ligação, foi necessária a redução do rigor para realizar as análises subseqüentes. Neste grupo, os autores precisaram utilizar um LOD mínimo de 0,40 para ordenação das marcas.

No presente trabalho, foram aplicados os parâmetros de LOD mínimo 2,0 para se estabelecer a ordem dos locos, limiar de recombinação de 0,40 cM e LOD mínimo de 1,0 para a determinação das fases de ligação. Para dois grupos, foi necessária a redução deste rigor para a realização das análises subseqüentes: o Grupo I teve LOD mínimo 0,65 para se estabelecer a ordem dos locos, limiar de recombinação de 0,40 cM e LOD mínimo de 0,64 para a determinação das fases de ligação e o Grupo II teve LOD mínimo 0,75 para se determinar o ordem dos locos, limiar de recombinação de 0,40 cM e LOD mínimo de 1,0 para a determinação das fases de ligação. O rigor utilizado para cada grupo de ligação encontra-se na Tabela 17.

Tabela 17. Rigor utilizado para determinação de cada grupo e das fases de ligação

\begin{tabular}{cccc}
\hline Grupo & Limiar de recombinação & $\begin{array}{c}\text { LOD mínimo para a ordenação } \\
\text { dos locos }\end{array}$ & $\begin{array}{c}\text { LOD mínimo para } \\
\text { determinação de fases }\end{array}$ \\
\hline 1 & 0,40 & 0,65 & 0,64 \\
2 & 0,40 & 0,75 & 1,00 \\
3 & 0,40 & 2,00 & 1,00 \\
4 & 0,40 & 2,00 & 1,00 \\
5 & 0,40 & 2,00 & 1,00 \\
6 & 0,40 & 2,00 & 1,00 \\
7 & 0,40 & 2,00 & 1,00 \\
8 & 0,40 & 2,00 & 1,00 \\
\hline
\end{tabular}

Todos os grupos de ligação que haviam sido obtidos para cada genitor pelo trabalho realizado por Lopes (2003) foram integrados com seus respectivos homólogos. A denominação do grupo se fez com base na ordem decrescente dos comprimentos (cM) obtidos. Portanto, a numeração dos grupos aqui adotada não corresponde àquela encontrada por Lopes (2003).

As fases de ligação foram codificadas com o auxílio de dois dígitos, os quais estão entre parênteses, para cada marcador alocado nos mapas. O primeiro dígito referese ao primeiro genitor, enquanto o segundo dígito ao outro genitor (Tabela 18). 
Os pares de locos que possuem o mesmo dígito na primeira posição estão em associação no primeiro genitor. Caso contrário, com dígitos diferentes, estão em repulsão. Como dito, o segundo dígito refere-se ao segundo genitor. Como exemplo, considere um loco A, do tipo bi-parental utilizado neste trabalho (hk $\mathrm{x}$ hk), com codificação de fase $\{00\}$, um loco B informativo, derivado do genitor IAPAR-06 (lm X $\mathrm{mm}$ ), com codificação de fase $\{0$ - $\}$ e um outro loco $\mathrm{C}$ informativo, oriundo do genitor IAPAR-123 (nn x np), com codificação de fase $\{-1\}$. Os dados moleculares do loco A possuem segregação do tipo 3:1 (h-:kk), e a presença de banda (alelo dominante) é representada pela letra “h”. Para o loco B, cuja segregação é do tipo 1:1 (lm:mm), o alelo dominante é representado pela letra “l”. Para o loco C, cuja segregação também é do tipo 1:1 (nn:np), o alelo dominante é representado pela letra “p” (Tabela 18).

Tabela 18. Codificação das fases de ligação entre os marcadores informativos dos genitores IAPAR-06 e IAPAR-123, individualmente, e entre os marcadores bi-parentais, informativos em ambos genitores

\begin{tabular}{ccc}
\hline Genitor informativo & Tipo de segregação & Codificação das fases \\
\hline IAPAR-06 & $\operatorname{lm} \times$ mm (1:1) & $\{0-\}$ ou $\{1-\}$ \\
IAPAR-123 & nn x np (1:1) & $\{-0\}$ ou $\{-1\}$ \\
Ambos & hk x hk, sendo (h-, kk), (3:1) & $\{00\},\{01\},\{10\}$ ou $\{11\}$ \\
\hline
\end{tabular}

As associações existentes entre esses três locos ligados são interpretadas da seguinte maneira: 1) os alelos do loco A estão em fase de associação com os alelos do loco B oriundo do primeiro genitor, ou seja, IAPAR-06. Entretanto, devido à falta de informação decorrente do tipo de marcador utilizado, não há como se determinar a fase de ligação entre os alelos desses dois locos para o segundo genitor, tendo em vista a não detecção de recombinação entre esses locos; 2) os alelos do loco A estão em fase de repulsão com os alelos do loco C oriundo do segundo genitor (IAPAR-123). Da mesma forma, não há como se determinar a fase de ligação entre os alelos desses dois locos para o primeiro genitor; e 3) não há informação quanto à fase de ligação existente entre os alelos dos locos B e C. Este exemplo está ilustrado na Figura 24. 


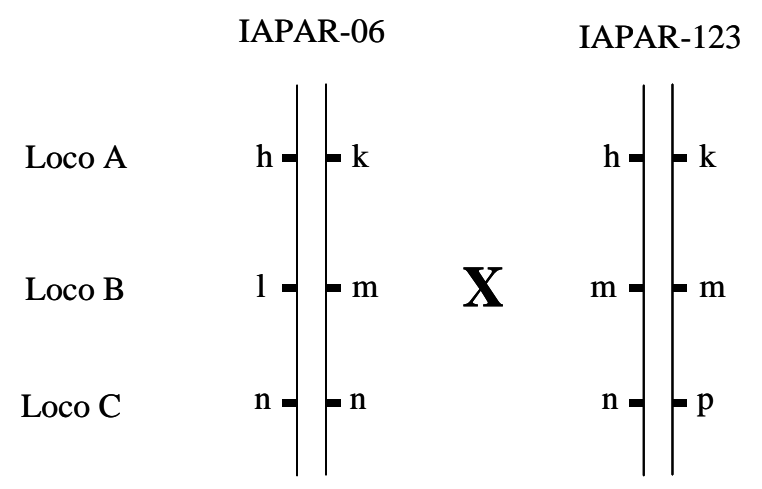

Figura 24 - Representação esquemática das possíveis fases de ligação entre três locos hipotéticos. Loco A, do tipo bi-parental; loco B informativo, oriundo do genitor IAPAR-06; loco C informativo, oriundo do genitor IAPAR-123. Pela estratégia duplo pseudocruzamento teste, somente os locos B e C seriam mapeados se usado, por exemplo, o programa computacional Mapmaker. O JoinMap permite a construção de um único mapa para estes três marcadores

O procedimento de mapeamento realizado pelo JoinMap envolve alguns passos que devem ser aqui discutidos. No primeiro passo ("round”), dentro de cada grupo, são trabalhadas somente as marcas que suportam um maior rigor de mapeamento (LOD 2,0). São testadas todas as marcas e aquelas que não se enquadram aguardam um próximo passo, o qual exige um menor rigor (LOD 1,0), procurando se utilizar as demais marcas para o mapeamento. Após esse passo, todas as demais marcas são alocadas no mapa sem o rigor dos passos anteriores.

Até o presente momento, para o maracujazeiro ainda não se tem a relação entre os mapas cromossômicos e os mapas genéticos já estabelecidos, ou seja, os mapas feitos com base em marcadores RAPD (Carneiro et al., 2002) e em AFLP (Lopes, 2003). O mapa cromossômico serviria como um padrão para as comparações entre os mapas gerados pelos diferentes estudos. Dada a inexistência de um mapa cromossômico e os problemas intrínsecos de ordenação dos marcadores dominantes, não há como saber a ordem mais correta dos locos dentro de cada grupo. Os resultados obtidos até o momento ficam à mercê do efeito de amostragem. Portanto, optou-se aqui pela 
utilização dos mapas oriundos do terceiro passo do processo de mapeamento realizado pelo JoinMap (Figuras 26 a 33).

Os grupos de ligação foram constituídos por 19 até 92 marcadores. O comprimento do menor grupo foi de 40,9 cM e o do maior 148,0 cM. O comprimento total do mapa, correspondente à soma do comprimento dos oito grupos, foi de 665,1 cM (Tabela 19).

Tabela 19. Número de marcadores AFLP e comprimento em cM (Haldane, 1919) de cada grupo de ligação do mapa integrado de maracujá-amarelo

\begin{tabular}{ccc}
\hline Grupo & Número de marcadores & Comprimento (cM) \\
\hline I & 30 & 148,0 \\
II & 92 & 106,6 \\
III & 19 & 91,9 \\
IV & 33 & 76,8 \\
V & 52 & 75,7 \\
VI & 26 & 63,0 \\
VII & $47(73)^{1 /}$ & 62,2 \\
VIII & 21 & 40,9 \\
Total & 320 & 665,1 \\
\hline
\end{tabular}

1/ Devido a complicações computacionais, para a análise de QRL, o Grupo VII teve 26 marcas descartadas, passando a conter 47 marcadores, ao invés de 73

O comprimento do mapa aqui apresentado, envolvendo o aumento de indivíduos da população segregante, a integração dos mapas dos dois genitores e a complementação com os marcadores 3:1, não pode ser comparado com o comprimento dos mapas obtidos por Lopes (2003), que calculou um comprimento total de 790,2 cM para o genitor IAPAR-06 e de 488,9 cM para o genitor IAPAR-123. Esses valores foram obtidos com base somente na soma das distâncias entre os marcadores que estavam ordenados em cada grupo. Lopes (2003) relata que foram desconsiderados os marcadores que não tiveram uma posição clara dentro do grupo, sendo, portanto, considerados como acessórios, sem entrarem nos cálculos para a obtenção dos comprimentos dos mapas.

Um outro ponto a ser considerado é que existe uma diferença no algoritmo de mapeamento entre os programas computacionais mais utilizados como o Mapmaker (Lander et al., 1987) e o JoinMap. Normalmente, o JoinMap produz mapas menores 
comparativamente aos do Mapmaker (Vuylsteke et al., 1999). Lopes (2003) utilizou o programa Mapmaker para realização de suas análises, mas como este programa computacional não trabalha com a mistura de marcadores com segregação 1:1 e 3:1, justifica-se o uso do programa JoinMap.

Para populações de tamanho infinito, as estimativas de máxima verossimilhança para as freqüências de recombinação são não-viesadas. Na prática, são utilizadas populações de tamanhos finitos. Neste caso, a ligação entre locos é testada e somente as estimativas de freqüência de recombinação com “LOD scores” significativos são mantidas nas análises. De forma geral, as estimativas envolvendo maiores freqüências de recombinação não ultrapassam este nível de significância, sendo ignoradas. Em populações finitas existe um viés para baixo no conjunto de valores das estimativas obtidas e consideradas como verdadeiras. Devido à pequena probabilidade de se observar recombinações para as configurações do “tipo 14” ( $r \times r, r \times a$ ou $a \times r)$, “LOD scores” significativos somente são obtidos, na maioria das vezes, quando as estimativas de recombinação correspondentes são iguais a zero (Maliepaard et al, 1997). Estes autores ainda relatam que estimativas iguais a zero foram alcançadas, mesmo sob elevados valores de freqüência de recombinação.

Vale salientar que o mapa construído até o momento, para este cruzamento, não é definitivo, pois o mesmo pode sofrer alterações de acordo com o aumento no número de indivíduos e/ou uso de diferentes tipos de marcadores, como os co-dominantes (microssatélites e outros), que poderão proporcionar mudanças na ordem das marcas, principalmente nas regiões mais adensadas do mapa.

Após as marcas terem sido atribuídas aos respectivos grupos de ligação, as estimativas das freqüências de recombinação, entre pares de marcadores, fornecem informações conflitantes quanto à ordenação dos locos. Isto é explicado pela presença de dados perdidos, ou devido a erros das estimativas das freqüências de recombinação, inerentes às configurações existentes entre os locos. Uma estratégia para solucionar esse problema é utilizada pelo JoinMap, usando todas as informações das freqüências de recombinação entre os pares de locos ponderadas pelos “LOD scores” visando estimar, 
simultaneamente, a ordem das marcas e as distâncias. Por exemplo, na determinação da distância B - C em um grupo formado por quatro marcadores na ordem $A-B-C-D$, a utilização das informações das estimativas entre A - B, A - C, B - C, B - D e C - D pode, ao final, fornecer uma estimativa mais acurada em relação ao uso isolado da estimativa B - C. O ideal seria que os marcadores A e D fossem do tipo $a b \times c d$, ou seja, marcadores totalmente informativos, podendo, por exemplo, B e C serem do tipo $a 0$ × $a 0$ (Maliepaard et al, 1997).

Regiões adensadas, aqui detectadas, podem ser conseqüência do tipo de marcador utilizado para o mapeamento. Vuylsteke et al. (1999) relatam que diversos estudos demonstram que a combinação das enzimas EcoR1/ Mse1 tende a revelar agrupamentos de locos (“clusters”) co-localizados com possíveis regiões centroméricas. Em contrapartida, combinações do tipo Pst1/ Mse1 produzem marcas com distribuição mais uniforme pelo genoma.

Agrupamentos de marcadores AFLP oriundos da combinação EcoR1/ Mse1 em regiões específicas dos cromossomos também apareceram nos mapas de batata (Van Eck et al., 1995), cevada (Becker et al., 1995), soja (Keim et al., 1997) e de Arabidopsis (Alonso-Blanco et al., 1998). De acordo com Rossi et al., 1996, citados por Vuylsteke et al. (1999), em Arabidopsis foi demonstrado que a região de heterocromatina pericentromérica fluoresce fortemente quando corada com o fluorocromo DAPI, o qual possui preferência por regiões do DNA ricas em Timina (T) e Adenina (A). Essa é uma explicação para a “clusterização” de marcadores oriundos da combinação EcoR1/ Mse1 nos centrômeros de Arabidopsis (Alonso-Blanco et al., 1998) e, possivelmente, nos genomas de outras espécies vegetais, pois essas enzimas têm sítios de restrição ricos em AT (Mse1 reconhece o sítio 5'-TTAA-3`, enquanto EcoR1 reconhece 5`-GAATTC-3`) (Saal \& Wricke, 2002). 


\subsection{Mapeamento de QRL}

Na Tabela 20 são mostradas as marcas ligadas a, pelo menos, uma das 13 variáveis fenotípicas, considerando os dois experimentos.

Levando-se em conta as análises de marcas simples, foram verificadas algumas diferenças quanto aos níveis de significância para cada data de avaliação e para posições das folhas. Esse fato pode ser explicado pelas interações significativas encontradas entre genótipo x data de avaliação e genótipo x posição das folhas, respectivamente. Essas interações também podem ser úteis para explicar a significância detectada para alguns marcadores isolados.

O teste de marca simples não revela o efeito do QTL, pois, como já relatado, a presença de um QTL de pequeno efeito próximo ao marcador ou a de um QTL de grande efeito longe do marcador, não podem ser discriminadas. Não há como associar uma marca de maior valor de significância com o possível local do QTL, pois o que deve ser analisado é o efeito dessas marcas em presença das demais dentro de um grupo de ligação devidamente construído. 
Tabela 20. Marcadores ligados a, pelo menos, uma das 13 variáveis fenotípicas, levando-se em conta os dois experimentos ( $p$-valor $<10 \%)$

\begin{tabular}{|c|c|c|c|c|c|c|c|c|c|c|c|c|c|c|c|}
\hline \multirow{2}{*}{ GL } & \multirow{2}{*}{ Locos } & \multicolumn{7}{|c|}{ Primeiro Experimento } & \multicolumn{6}{|c|}{ Segundo Experimento } & \multirow{2}{*}{ NIND } \\
\hline & & DT1 & DT2 & DT3 & DT4 & P1 & P2 & P3 & 2DT1 & 2DT2 & 2DT3 & $2 \mathrm{P} 1$ & $2 \mathrm{P} 2$ & $2 \mathrm{P} 3$ & \\
\hline 1 & EM16188 & & & & & & 0,063 & & & & 0,019 & 0,016 & 0,055 & & 104 \\
\hline 1 & EM21161 & 0,023 & 0,067 & 0,027 & 0,026 & & 0,067 & 0,047 & & & & & & 0,041 & 103 \\
\hline 1 & PM02134 & & & & & & 0,046 & & & & 0,022 & 0,021 & & 0,093 & 69 \\
\hline 1 & EM04244 & & & & & & 0,054 & & & & & & & & 104 \\
\hline 1 & EM10145 & & & & & & 0,033 & & & & & & & & 103 \\
\hline 1 & EM12199 & & & & & & 0,032 & & & & & & & & 103 \\
\hline 1 & EM13335 & & & & & & 0,057 & & & & 0,089 & 0,051 & & & 101 \\
\hline 1 & EM151400 & & & & & & 0,069 & & & & & & & & 104 \\
\hline 1 & EM15204 & & & & & & & 0,085 & & & & & & & 101 \\
\hline 1 & EM16260 & & & & & & 0,042 & & & & & & & & 104 \\
\hline 1 & EM16232 & & & & & & 0,045 & & & & & & & & 104 \\
\hline 1 & EM20321 & & & & & & 0,063 & & & & & & & & 103 \\
\hline 1 & EM21304 & & & & & & 0,054 & & & & & & & & 103 \\
\hline 1 & EM24470 & & & & & & 0,080 & & & & & & & & 101 \\
\hline 1 & PM06192 & & 0,096 & & & & 0,013 & 0,048 & & & & 0,086 & & & 103 \\
\hline 1 & EM16850 & & & & & 0,076 & & & & & 0,059 & 0,089 & & & 66 \\
\hline 1 & EM1695 & & & 0,091 & 0,017 & 0,012 & 0,014 & 0,066 & & & & & & & 97 \\
\hline 1 & EM1891 & & & & & & 0,052 & & & & 0,084 & & & 0,034 & 104 \\
\hline 2 & EM01234 & & 0,081 & 0,077 & 0,070 & 0,068 & & & & & & & & & 100 \\
\hline 2 & EM01130 & & & & & & 0,033 & & 0,031 & 0,030 & 0,052 & 0,016 & & & 100 \\
\hline 2 & EM05232 & & & & & & & & & & & & & 0,036 & 104 \\
\hline 2 & EM13620 & 0,056 & 0,021 & 0,074 & 0,085 & & & & & & & & & 0,023 & 100 \\
\hline 2 & EM13275 & & & & & & & & & & & & & 0,020 & 99 \\
\hline 2 & EM13226 & & & & & & & & & & & & & 0,045 & 102 \\
\hline 2 & EM14405 & & & & & & & & & & & & & 0,071 & 101 \\
\hline 2 & EM1478 & & & & & & & & & & & & & 0,083 & 100 \\
\hline 2 & EM1790 & & & & & & & & & & & & & 0,076 & 101 \\
\hline 2 & EM18489 & & & & & & & & & & & & & 0,029 & 104 \\
\hline 2 & EM20107 & & & & & & & & & & & & & 0,063 & 103 \\
\hline 2 & EM22265 & & & & & & & & & & & & & 0,052 & 104 \\
\hline 2 & EM23317 & & 0,057 & 0,090 & & & & & 0,056 & & & & & 0,083 & 67 \\
\hline 2 & РM09144 & & 0,082 & & & & & 0,018 & & & & & & & 95 \\
\hline 2 & EM01238 & & & & & & & & & 0,032 & 0,024 & 0,012 & 0,054 & & 100 \\
\hline 2 & EM021037 & & 0,035 & 0,013 & 0,028 & 0,019 & & 0,060 & 0,022 & 0,011 & 0,015 & & 0,015 & 0,001 & 102 \\
\hline 2 & EM02145 & & 0,078 & 0,038 & 0,071 & 0,048 & & 0,086 & & 0,052 & 0,045 & & 0,042 & 0,004 & 102 \\
\hline 2 & EM02144 & & 0,034 & 0,011 & 0,025 & 0,017 & & 0,060 & 0,049 & 0,022 & 0,027 & & 0,018 & 0,003 & 102 \\
\hline 2 & EM03276 & & & & & & & & & 0,032 & 0,019 & 0,015 & 0,030 & & 104 \\
\hline 2 & EM03264 & & & & & & & & & 0,030 & 0,018 & 0,010 & 0,038 & & 104 \\
\hline 2 & EM04138 & & & & & & & & & 0,030 & 0,018 & 0,010 & 0,038 & & 104 \\
\hline 2 & EM05244 & & & & & & & & & 0,030 & 0,018 & 0,010 & 0,038 & & 104 \\
\hline
\end{tabular}


Tabela 20. Marcadores ligados a, pelo menos, uma das 13 variáveis fenotípicas, levando-se em conta os dois experimentos ( $p$-valor $<10 \%)$

\begin{tabular}{|c|c|c|c|c|c|c|c|c|c|c|c|c|c|c|c|}
\hline \multirow{2}{*}{ GL } & \multirow{2}{*}{ Locos } & \multicolumn{7}{|c|}{ Primeiro Experimento } & \multicolumn{6}{|c|}{ Segundo Experimento } & \multirow{2}{*}{ NIND } \\
\hline & & DT1 & DT2 & DT3 & DT4 & P1 & P2 & P3 & 2DT1 & 2DT2 & 2DT3 & 2P1 & $2 \mathrm{P} 2$ & $2 \mathrm{P} 3$ & \\
\hline 2 & EM061227 & & 0,038 & 0,014 & 0,031 & 0,020 & & 0,070 & 0,051 & 0,022 & 0,028 & & 0,017 & 0,004 & 103 \\
\hline 2 & EM10300 & & 0,033 & 0,008 & 0,019 & 0,014 & & 0,055 & 0,059 & 0,024 & 0,027 & & 0,022 & 0,003 & 103 \\
\hline 2 & EM12167 & & & & & & & & & 0,025 & 0,024 & 0,006 & 0,045 & & 103 \\
\hline 2 & EM14379 & & & & & & & & & 0,041 & 0,023 & 0,022 & 0,020 & & 104 \\
\hline 2 & EM16675 & & & & & & & & & 0,042 & 0,022 & 0,017 & 0,035 & & 103 \\
\hline 2 & EM17125 & & & & & & & & & 0,076 & 0,039 & 0,024 & & & 101 \\
\hline 2 & EM18332 & & & 0,092 & & 0,020 & & & 0,084 & 0,088 & 0,058 & & 0,026 & 0,017 & 103 \\
\hline 2 & EM18139 & & 0,027 & 0,009 & 0,016 & 0,025 & & 0,024 & & & & & & 0,021 & 81 \\
\hline 2 & EM18137 & & & & & & & & & 0,087 & 0,054 & 0,024 & & & 104 \\
\hline 2 & EM19276 & & 0,064 & 0,027 & 0,064 & 0,044 & & 0,098 & 0,088 & 0,042 & 0,068 & & 0,073 & 0,012 & 102 \\
\hline 2 & EM20261 & & & & & & & & & 0,034 & 0,019 & 0,013 & 0,063 & 0,062 & 103 \\
\hline 2 & EM21259 & & & & & & & & & 0,036 & 0,026 & 0,014 & 0,050 & & 103 \\
\hline 2 & EM21254 & & & & & & & & 0,054 & 0,048 & & & & & 103 \\
\hline 2 & EM21204 & & & & & & & & 0,085 & 0,011 & 0,005 & 0,007 & 0,022 & 0,021 & 103 \\
\hline 2 & EM23222 & & & & & & & & & & & & 0,058 & & 67 \\
\hline 2 & EM2378 & & 0,008 & 0,002 & 0,007 & 0,025 & 0,076 & 0,010 & & & & & & 0,031 & 68 \\
\hline 2 & EM2488 & & & & & & & & 0,097 & 0,014 & 0,011 & 0,007 & 0,015 & 0,089 & 103 \\
\hline 2 & PM02131 & & & & & & & & & 0,086 & & & 0,022 & & 68 \\
\hline 2 & РМ03338 & & & & & & & & 0,031 & 0,013 & 0,044 & 0,034 & 0,045 & & 69 \\
\hline 2 & РM06239 & & & & & & & & & 0,054 & 0,028 & 0,015 & 0,068 & & 102 \\
\hline 2 & PM09198 & 0,045 & 0,007 & 0,006 & 0,052 & & 0,086 & 0,046 & & & 0,040 & & 0,091 & 0,022 & 94 \\
\hline 2 & PM10149 & & & & & & & & & 0,096 & 0,092 & 0,061 & 0,076 & & 104 \\
\hline 2 & EM02242 & & & & 0,086 & 0,064 & & & & & & & & & 102 \\
\hline 2 & EM05262 & & & & & & & & & & & 0,072 & & & 104 \\
\hline 2 & EM081497 & 0,042 & 0,034 & 0,020 & 0,049 & & & & & & & & & & 67 \\
\hline 2 & EM09380 & & & & & & & & & & & & & 0,098 & 66 \\
\hline 2 & EM0970 & 0,061 & 0,039 & 0,023 & 0,059 & & & & & & & & & & 69 \\
\hline 2 & EM13450 & & & & & & & & 0,087 & 0,058 & 0,019 & 0,030 & 0,030 & 0,054 & 65 \\
\hline 2 & EM14253 & & & & & 0,034 & & & & & & & & & 62 \\
\hline 2 & EM1484 & & & & & & & & 0,037 & 0,014 & 0,017 & 0,037 & 0,008 & 0,041 & 104 \\
\hline 2 & EM1496 & & & & & & & 0,089 & & & & & & & 104 \\
\hline 2 & EM16618 & 0,034 & 0,013 & 0,018 & 0,024 & 0,013 & 0,031 & 0,047 & 0,004 & 0,001 & 0,002 & 0,029 & 0,0004 & 0,002 & 43 \\
\hline 2 & EM16715 & & & 0,070 & & 0,098 & & 0,074 & & & & & & & 104 \\
\hline 2 & EM18217 & & & & & & & & & & & & 0,095 & & 100 \\
\hline 2 & EM20284 & & & & & & & & & & 0,096 & & 0,031 & & 103 \\
\hline 2 & EM20288 & & & & & & & & & & & 0,076 & & & 103 \\
\hline 2 & EM24124 & & & & & & & & 0,055 & 0,036 & 0,051 & 0,082 & 0,029 & & 100 \\
\hline 2 & EM24750 & & & 0,093 & & & & & & & & & & & 99 \\
\hline 2 & PM02640 & & 0,008 & 0,013 & 0,020 & 0,009 & 0,011 & 0,057 & 0,034 & 0,018 & 0,018 & 0,079 & 0,003 & 0,080 & 32 \\
\hline 2 & PM06226 & & & & & & & & & & & 0,063 & & & 103 \\
\hline
\end{tabular}


Tabela 20. Marcadores ligados a, pelo menos, uma das 13 variáveis fenotípicas, levando-se em conta os dois experimentos ( $p$-valor $<10 \%)$

\begin{tabular}{|c|c|c|c|c|c|c|c|c|c|c|c|c|c|c|c|}
\hline \multirow{2}{*}{ GL } & \multirow{2}{*}{ Locos } & \multicolumn{7}{|c|}{ Primeiro Experimento } & \multicolumn{6}{|c|}{ Segundo Experimento } & \multirow{2}{*}{ NIND } \\
\hline & & DT1 & DT2 & DT3 & DT4 & P1 & P2 & P3 & 2DT1 & 2DT2 & 2DT3 & 2P1 & $2 \mathrm{P} 2$ & $2 \mathrm{P} 3$ & \\
\hline 3 & EM20135 & & & & & 0,095 & & & & & & & & & 103 \\
\hline 3 & EM2484 & & & & & & 0,041 & & & & 0,057 & & 0,058 & 0,050 & 103 \\
\hline 3 & PM08161 & 0,098 & & & & & & & & & & & & & 98 \\
\hline 3 & EM04114 & & 0,064 & 0,039 & 0,016 & 0,088 & 0,028 & 0,014 & 0,011 & 0,022 & 0,011 & 0,045 & 0,021 & 0,018 & 104 \\
\hline 3 & EM06684 & 0,096 & 0,015 & 0,002 & 0,002 & 0,051 & 0,001 & 0,007 & 0,003 & 0,002 & 0,002 & 0,002 & 0,048 & 0,001 & 104 \\
\hline 3 & EM09146 & & 0,044 & 0,028 & 0,013 & 0,029 & 0,007 & 0,027 & 0,001 & 0,002 & 0,001 & 0,019 & 0,003 & 0,001 & 104 \\
\hline 3 & EM10236 & & 0,064 & 0,057 & 0,035 & 0,075 & 0,024 & 0,037 & 0,001 & 0,002 & 0,001 & 0,012 & 0,003 & 0,002 & 102 \\
\hline 3 & EM17240 & & 0,069 & 0,066 & 0,043 & 0,083 & 0,034 & 0,032 & 0,001 & 0,003 & 0,001 & 0,012 & 0,005 & 0,004 & 101 \\
\hline 3 & EM22433 & & 0,014 & 0,005 & 0,002 & 0,012 & 0,001 & 0,009 & 0,002 & 0,004 & 0,0009 & 0,009 & 0,003 & 0,001 & 99 \\
\hline 3 & EM24217 & & 0,032 & 0,024 & 0,012 & 0,027 & 0,007 & 0,020 & 0,001 & 0,003 & 0,001 & 0,014 & 0,002 & 0,002 & 102 \\
\hline 3 & PM10267 & 0,001 & 0,0003 & 0,0005 & 0,0008 & 0,014 & 0,003 & 0,0001 & 0,001 & 0,005 & 0,0003 & 0,001 & 0,002 & 0,003 & 101 \\
\hline 3 & EM062644 & & & & 0,081 & & 0,024 & & & & & & & & 94 \\
\hline 3 & EM10233 & & & & & 0,056 & 0,099 & & & 0,054 & 0,033 & & 0,088 & 0,024 & 101 \\
\hline 3 & EM22272 & & & & & & & 0,077 & 0,049 & & & & & & 104 \\
\hline 4 & EM0463 & & & & & & 0,082 & 0,081 & & & & & & & 69 \\
\hline 4 & EM11321 & & & & & & & 0,051 & & & & & & & 102 \\
\hline 4 & EM12182 & & & 0,034 & 0,046 & 0,034 & 0,098 & & & & & & & 0,078 & 103 \\
\hline 4 & EM15237 & & & 0,096 & 0,059 & & & 0,022 & 0,056 & 0,047 & & 0,018 & 0,055 & & 101 \\
\hline 4 & EM16308 & 0,055 & & & & & & & & & & & & & 103 \\
\hline 4 & EM20231 & 0,097 & & & & & & & & & & & & & 103 \\
\hline 4 & EM2276 & 0,090 & & & & & & & & & & & & & 99 \\
\hline 4 & PM06186 & 0,065 & & & & & & & & & & & & & 103 \\
\hline 5 & EM16354 & 0,093 & & & & & & & & & & & & & 104 \\
\hline 5 & EM15248 & & 0,027 & 0,072 & & & & 0,036 & & & & & & & 101 \\
\hline 5 & EM19246 & & & & & 0,079 & & & & & & & & & 103 \\
\hline 5 & PM04243 & 0,059 & 0,086 & & 0,068 & & & 0,040 & & & & & & & 103 \\
\hline 5 & EM16270 & & & & & 0,074 & & & & & & 0,069 & & & 104 \\
\hline 5 & EM20219 & & 0,084 & & & & & 0,050 & & & & & & & 97 \\
\hline 5 & PM03188 & & & & & & & 0,027 & & & & 0,080 & & & 104 \\
\hline 5 & PM03265 & & & & & & & & 0,063 & 0,087 & & & & & 102 \\
\hline 5 & PM04184 & & & & & & & & & & & & & 0,050 & 103 \\
\hline 5 & PM04214 & & & & & 0,049 & & & & & & & & & 101 \\
\hline 6 & EM021560 & 0,075 & 0,090 & & & & & & & & & & & 0,081 & 102 \\
\hline 6 & EM16397 & 0,015 & 0,032 & 0,038 & & & & & 0,011 & 0,033 & 0,096 & 0,021 & & & 103 \\
\hline 6 & EM17190 & 0,012 & 0,024 & 0,014 & 0,046 & & 0,082 & 0,092 & 0,048 & 0,064 & & 0,016 & & & 101 \\
\hline 6 & EM23215 & 0,010 & 0,020 & 0,004 & 0,004 & 0,024 & 0,048 & 0,034 & 0,022 & 0,058 & & & & 0,012 & 66 \\
\hline 6 & PM03242 & 0,001 & 0,012 & 0,012 & 0,032 & & 0,049 & & 0,032 & 0,053 & 0,073 & 0,016 & & & 104 \\
\hline 6 & EM01156 & 0,031 & 0,024 & 0,085 & 0,069 & 0,039 & 0,039 & 0,032 & & & & & 0,060 & & 100 \\
\hline 6 & EM03219 & 0,007 & 0,014 & 0,019 & 0,008 & 0,028 & 0,006 & 0,001 & 0,010 & 0,012 & 0,006 & 0,005 & 0,007 & & 104 \\
\hline 6 & EM08395 & 0,051 & & & & & & 0,007 & & & & & & & 103 \\
\hline
\end{tabular}


Tabela 20. Marcadores ligados a, pelo menos, uma das 13 variáveis fenotípicas, levando-se em conta os dois experimentos ( $p$-valor $<10 \%)$

\begin{tabular}{|c|c|c|c|c|c|c|c|c|c|c|c|c|c|c|c|}
\hline \multirow{2}{*}{ GL } & \multirow{2}{*}{ Locos } & \multicolumn{7}{|c|}{ Primeiro Experimento } & \multicolumn{6}{|c|}{ Segundo Experimento } & \multirow{2}{*}{ NIND } \\
\hline & & DT1 & DT2 & DT3 & DT4 & P1 & P2 & P3 & 2DT1 & 2DT2 & 2DT3 & $2 \mathrm{P} 1$ & $2 \mathrm{P} 2$ & $2 \mathrm{P} 3$ & \\
\hline 6 & EM11800 & 0,048 & 0,034 & 0,077 & 0,052 & & 0,041 & 0,004 & & & 0,063 & 0,047 & 0,045 & & 102 \\
\hline 6 & EM13880 & & & & & & & & & & & 0,047 & & & 97 \\
\hline 6 & PM023558 & & & & 0,081 & 0,068 & 0,091 & 0,044 & & & & & 0,056 & & 69 \\
\hline 6 & PM0783 & 0,013 & 0,013 & 0,029 & 0,022 & & 0,015 & 0,001 & & & 0,035 & 0,011 & 0,041 & & 104 \\
\hline 6 & PM10129 & 0,028 & 0,023 & 0,035 & 0,022 & 0,081 & 0,021 & 0,001 & 0,081 & 0,044 & 0,017 & 0,011 & 0,015 & & 104 \\
\hline 6 & EM01800 & & & & & 0,081 & & & & & & & 0,072 & & 101 \\
\hline 6 & EM17400 & 0,001 & 0,002 & 0,001 & 0,002 & 0,069 & 0,008 & 0,0003 & 0,041 & 0,013 & 0,007 & 0,0004 & 0,058 & & 98 \\
\hline 6 & EM21128 & $<0,0001$ & 0,0001 & 0,0003 & 0,0005 & 0,008 & 0,002 & 0,0002 & 0,002 & 0,001 & 0,0009 & $<0,0001$ & 0,003 & 0,062 & 102 \\
\hline 6 & EM24108 & $<0,0001$ & 0,0002 & 0,0002 & 0,0004 & 0,007 & 0,004 & 0,0002 & 0,001 & 0,001 & 0,001 & $<0,0001$ & 0,005 & 0,058 & 101 \\
\hline 7 & EM07236 & & & & & 0,090 & 0,040 & & & & & & & & 104 \\
\hline 7 & EM08390 & 0,096 & & & & & & & & & & & & & 103 \\
\hline 7 & EM15234 & & & & & & & & & & & 0,073 & & & 101 \\
\hline 7 & EM18305 & 0,016 & & & & & & & & & & & & & 102 \\
\hline 7 & EM1995 & 0,009 & & & & & & & & 0,046 & & & & 0,092 & 102 \\
\hline 7 & EM15594 & & & & & & & & & 0,083 & 0,041 & & & 0,079 & 104 \\
\hline 7 & EM13370 & & & & & & & & & 0,048 & & & & & 52 \\
\hline 7 & EM21162 & & & & & & & & 0,048 & & & & & 0,070 & 101 \\
\hline 8 & EM06717 & & & & & 0,097 & & & & & & & & & 103 \\
\hline 8 & EM18124 & & 0,069 & & & & & 0,055 & & & & & & & 104 \\
\hline 8 & EM0986 & & & & & & & & & 0,062 & 0,066 & & 0,052 & 0,031 & 101 \\
\hline 8 & РM03245 & & & & & & & & & 0,094 & & & & 0,017 & 101 \\
\hline 8 & PM06244 & & & & & & & & & & & & & 0,079 & 67 \\
\hline 8 & PM06242 & & & & & & & & & & 0,049 & 0,052 & 0,091 & 0,059 & 64 \\
\hline 8 & PM08302 & 0,098 & & & & & & & & & 0,078 & 0,098 & 0,093 & 0,082 & 68 \\
\hline 8 & EM03102 & 0,057 & 0,034 & 0,092 & & & & 0,029 & & & 0,031 & 0,040 & & 0,026 & 97 \\
\hline 8 & EM16165 & & & & & & & 0,090 & & & 0,032 & 0,095 & & 0,007 & 103 \\
\hline
\end{tabular}

Houve alguns problemas durante o processo de mapeamento dos QRL no Grupo VII. Das 13 variáveis fenotípicas, somente três tiveram suas análises realizadas sem problemas (DT2, DT4 e P2), mas, para as demais variáveis, o programa computacional MapQTL 4.0 não conseguiu executar as análises. Somente para este grupo, optou-se por utilizar o mapa oriundo do segundo passo do processo de mapeamento realizado pelo JoinMap. Com isso, o mapa passou a conter 73 ao invés de 47 marcas e um comprimento de 80,2 cM ao invés de 62,2 cM (Figura 25). 


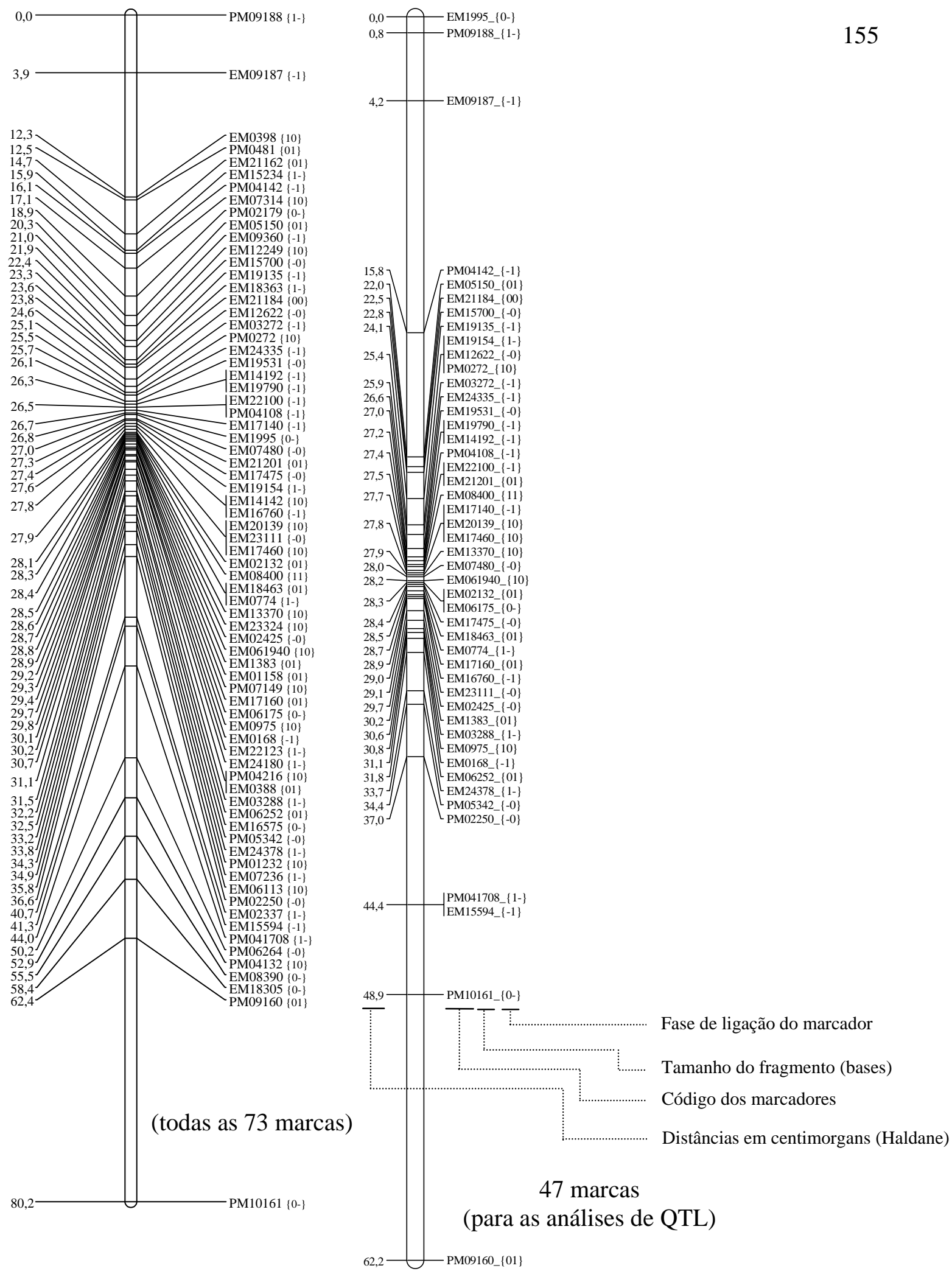

Figura 25 - Mapa genético - Grupo VII 
Para a construção do mapa genético todos os locos foram utilizados, mesmo possuindo dados perdidos. Entretanto, para a realização da regressão, para obtenção dos marcadores co-fatores, com vista ao mapeamento de QRL, os indivíduos e os locos com dados perdidos tornam-se problemáticos, pois não são considerados no processo de análise. Existem duas possibilidades para contornar esse problema: retirar-se os locos ou os indivíduos com dados perdidos das análises. Retirar os indivíduos não é uma boa alternativa para análises de QTL, sendo, mais indicada a retirada dos marcadores, a não ser que esses locos estejam ligados a QTL. Considere o seguinte exemplo hipotético (Tabela 21):

Tabela 21. Exemplo hipotético da caracterização molecular de 10 indivíduos para cinco locos marcadores

\begin{tabular}{cccccc}
\hline Indivíduo & Marca 1 & Marca 2 & Marca 3 & Marca 4 & Marca 5 \\
\hline 1 & 0 & 0 & 0 & 0 & 1 \\
2 & 1 & 1 & 0 & 1 & 1 \\
3 & - & 1 & 0 & 1 & 1 \\
4 & 1 & - & 0 & 1 & 1 \\
5 & 1 & 1 & 0 & 1 & 1 \\
6 & 0 & 1 & 1 & 1 & 1 \\
7 & 1 & 1 & 0 & 0 & 0 \\
8 & 1 & 0 & 0 & 1 & 1 \\
9 & 1 & 1 & 1 & 1 & 1 \\
10 & 0 & 0 & 1 & 0 & 0 \\
\hline
\end{tabular}

No processo de construção do modelo de regressão, os indivíduos 3 e 4 não seriam considerados, pois é como se eles não existissem. Os indivíduos 3 e 4 não possuem informação nos locos 1 e 2, respectivamente. Portanto, caso forem retirados da análise os locos 1 e 2, os 10 indivíduos poderiam ser considerados. No processo de construção da regressão múltipla são selecionadas as marcas que não possuam informações redundantes; dessa forma, cada marcador selecionado está, teoricamente, ligado a um QRL diferente e isso tem suas implicações:

a) Se os locos 1 e 2 não estiverem ligados a QRL, eles podem ser eliminados sem interferir na análise, pois não possuem informações sobre QRL; 
b) Se os locos 1 e/ou 2 estiverem ligados a QRL e existir algum outro loco ligado, este irá contemplar a informação perdida, até porque se o marcador que fica na regressão é o que deve estar mais fortemente ligado e os marcadores que não entraram na análise seriam descartados;

c) Se os locos 1 ou 2 estiverem ligados a QRL ao quais nenhum outro loco está ligado, então, haverá perda de informação. A solução seria realizar as análises com um número menor de indivíduos. No exemplo acima, seriam eliminados os indivíduos 3 e 4 e seriam usados todos os locos, sendo a população composta de 8 ao invés de 10 indivíduos.

Neste trabalho, existem dados perdidos para diferentes indivíduos e locos. Considerando os dados fenotípicos obtidos no primeiro experimento, 60 locos demonstraram estar ligados a pelo menos um dos sete fenótipos mensurados. No segundo experimento, um total de 75 locos demonstrou estar ligado a pelo menos um dos seis fenótipos mensurados (Tabela 16).

Para a realização da regressão linear múltipla, visando à obtenção das variáveis co-fatoras a serem utilizadas no mapeamento de QRL, algumas simulações foram realizadas para possibilitar uma situação intermediária, ou seja, aproveitar as informações de um número maior de indivíduos e abranger uma maior quantidade de marcas (Tabela 22). O mesmo estudo foi realizado para o segundo experimento.

Para ambos experimentos, foram considerados os resultados das simulações $D$ como as mais representativas. As análises de regressão múltipla foram realizadas para a obtenção das marcas co-fatoras, adotando o procedimento "stepwise", com níveis de significância de 0,05 tanto para os marcadores entrarem, como para permanecerem no modelo. Assim, para o primeiro experimento, as marcas co-fatoras obtidas para as sete variáveis foram obtidas com base nas informações provenientes de 48 marcas ligadas e um efetivo de 60 indivíduos. Para o segundo experimento, foram utilizadas as informações provenientes de 63 marcas ligadas e de 63 indivíduos. As marcas co-fatoras utilizadas para cada experimento estão representadas na Tabela 23. 
Tabela 22. Simulações realizadas de forma a possibilitar a utilização de um número representativo de indivíduos e marcadores para a construção dos modelos de regressão múltipla

\begin{tabular}{cccccccc}
\hline Simulação & $\begin{array}{c}\text { Primeiro Experimento } \\
\text { Número } \\
\text { de marcas }\end{array}$ & $\begin{array}{c}\text { Número de } \\
\text { indivíduos }\end{array}$ & $\begin{array}{c}\text { Indivíduos } \\
\text { efetivos }\end{array}$ & Simulação & $\begin{array}{c}\text { Segundo Experimento } \\
\text { de marcas }\end{array}$ & $\begin{array}{c}\text { Número de } \\
\text { indivíduos }\end{array}$ & $\begin{array}{c}\text { Indivíduos } \\
\text { efetivos }\end{array}$ \\
\hline A & 60 & 104 & 18 & $\mathrm{~A}$ & 75 & 104 & 18 \\
$\mathrm{~B}$ & 50 & 104 & 55 & $\mathrm{~B}$ & 64 & 104 & 56 \\
$\mathrm{C}^{1 /}$ & 50 & 102 & 55 & $\mathrm{C}$ & 64 & 102 & 56 \\
$\mathrm{D}$ & 48 & 102 & 60 & $\mathrm{D}$ & 63 & 102 & 63 \\
$\mathrm{E}$ & 35 & 102 & 87 & $\mathrm{E}$ & 49 & 102 & 85 \\
F & 20 & 102 & 102 & $\mathrm{~F}$ & 27 & 102 & 102 \\
\hline
\end{tabular}

A= Sem a exclusão de indivíduos e/ou marcadores; B= Exclusão das marcas quando havia menos que 94 indivíduos genotipados; $\mathrm{C}^{1 /}=$ Dois indivíduos foram retirados, pois apresentavam menos que 45 marcas; $\mathrm{C}^{2 /}=$ Dois indivíduos foram retirados, pois apresentavam menos que 58 marcas; $\mathrm{D}=$ Exclusão das marcas quando havia menos que 95 indivíduos; E= Exclusão das marcas quando havia menos que 100 indivíduos; e F=Exclusão de todas as marcas com dados perdidos, considerando os 102 indivíduos

Tabela 23. Marcas co-fatoras obtidas a partir das simulações para a construção dos modelos de regressão múltipla

\begin{tabular}{|c|c|c|c|c|c|c|}
\hline \multirow[b]{2}{*}{ Variável } & \multicolumn{3}{|c|}{ Primeiro Experimento } & \multicolumn{3}{|c|}{ Segundo Experimento } \\
\hline & Marcas co-fatoras & $\mathrm{R}^{2}$ Parcial & $\begin{array}{c}\text { Grupo de } \\
\text { ligação }\end{array}$ & Marcas co-fatoras & $\mathrm{R}^{2}$ Parcial & $\begin{array}{c}\text { Grupo de } \\
\text { ligação }\end{array}$ \\
\hline \multirow{5}{*}{ DT1 } & EM24108 & 0,201 & 6 & EM24108 & 0,131 & 6 \\
\hline & $\begin{array}{l}\text { EIV124100 } \\
\text { EM1995 }\end{array}$ & $\begin{array}{l}0,201 \\
0.119\end{array}$ & $\begin{array}{l}0 \\
7\end{array}$ & EM1995 & 0,094 & 7 \\
\hline & PM06192 & 0,119 & 1 & EM021037 & 0,076 & 2 \\
\hline & PIVI019192 & $\begin{array}{l}0,055 \\
0,049\end{array}$ & 1 & EM16188 & 0,052 & 1 \\
\hline & EM16232 & & & EM1484 & 0,043 & 2 \\
\hline \multirow{4}{*}{ DT2 } & & & & EM24108 & 0,134 & 6 \\
\hline & EM24108 & 0,216 & 6 & EM1995 & 0,091 & 7 \\
\hline & PM06192 & 0,055 & 1 & EM021037 & 0,080 & 2 \\
\hline & & & & EM12167 & 0,059 & 2 \\
\hline \multirow{5}{*}{ DT3 } & & & & EM21204 & 0,081 & 2 \\
\hline & EM24108 & 0,217 & 6 & EM1995 & 0,094 & 7 \\
\hline & EM1995 & 0,093 & 7 & EM16188 & 0,059 & 1 \\
\hline & PM06192 & 0,053 & 1 & EM021037 & 0,058 & 2 \\
\hline & & & & EM18332 & 0,046 & 2 \\
\hline DT4 & EM24108 & 0,195 & 6 & - & - & \\
\hline \multirow{5}{*}{$\mathrm{P} 1$} & EM24108 & 0,113 & 6 & & & \\
\hline & EM08395 & 0,108 & 6 & EM24108 & 0,157 & 6 \\
\hline & EM1995 & 0,089 & 7 & EM16188 & 0,090 & 1 \\
\hline & EM1695 & 0,065 & 1 & PM10267 & 0,067 & 3 \\
\hline & EM16397 & 0,045 & 6 & & & \\
\hline \multirow{5}{*}{ P2 } & & & & EM24108 & 0,128 & 6 \\
\hline & EM24108 & 0,167 & 6 & EM1995 & 0,083 & 7 \\
\hline & EM07236 & 0,090 & 7 & EM021037 & 0,071 & 2 \\
\hline & PM06192 & 0,083 & 1 & EM16188 & 0,047 & 1 \\
\hline & & & & EM1484 & 0,043 & 2 \\
\hline \multirow{4}{*}{ P3 } & EM24108 & 0,194 & 6 & PM03245 & 0,131 & 8 \\
\hline & PM06192 & 0,064 & 1 & EM021037 & 0,156 & 2 \\
\hline & PM03188 & $\begin{array}{l}0,062 \\
0,051\end{array}$ & $\begin{array}{l}5 \\
7\end{array}$ & EM1995 & 0,076 & 7 \\
\hline & $\begin{array}{c}\text { EM1995 } \\
\text { EM15248 }\end{array}$ & $\begin{array}{l}0,051 \\
0,049\end{array}$ & $\begin{array}{l}7 \\
5\end{array}$ & EM24108 & 0,048 & 6 \\
\hline
\end{tabular}

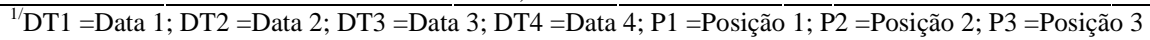


Embora os coeficientes de determinação parcial ( $\mathrm{R}^{2}$ parcial) indiquem o quanto determinado marcador explica a variação fenotípica da população segregante, isso não deve ser interpretado como o efeito do QRL, uma vez que esta estratégia não considera a ocorrência de recombinação entre o marcador e o QRL. Deve-se tomar esse tipo de informação como uma análise de marcas simples, via regressão múltipla. Vale salientar, também, que devido à presença de dados perdidos, como discutido anteriormente, esses valores estão relacionados aos dados usados nas simulações, as quais serviram para indicar as marcas a serem utilizadas como co-fatoras nas análises de mapeamento de QRL.

Foram realizadas as análises para cada variável e experimento separadamente. Também, foram realizadas as análises envolvendo os dados fenotípicos obtidos por Lopes (2003) com a finalidade de verificar o efeito do aumento do número de indivíduos e de se ter realizado a integração dos mapas dos genitores.

Ao lado de cada grupo de ligação estão apresentados os resultados das análises dos dois experimentos e dos dados obtidos por Lopes (2003). Algumas análises não foram realizadas, principalmente nos Grupos II e VII (Figuras 26 a 33). O desempenho do sistema computacional falhava bruscamente durante parte do processo das análises, tornando-as demasiadamente lentas ou até mesmo ocasionando algumas interrupções.

A barra colorida apresentada entre o grupo de ligação e o gráfico com as coordenadas LOD x posição no mapa, representa o intervalo de confiança de 95\% para o posicionamento do QRL (Lynch \& Walsh, 1998), ou seja, o intervalo formado considerando-se 1,0 LOD abaixo do maior pico de LOD apresentado pela variável em questão. As barras mostram diferentes amplitudes e diferentes posicionamentos, pois algumas análises apresentaram resultados distintos.

Existem dois limiares (“threshold”) para a deteç̧ão dos QTL (Van Ooijen, 1999), sendo um ao nível cromossômico e outro genômico, o qual é sempre maior. Como são procurados QTL em todo o genoma, o limiar ao nível genômico é o correto. Vale relatar que, em algumas situações, um pico somente seria significativo caso fosse utilizado o limiar cromossômico. Nesse caso, estatisticamente, não haveria evidência de 
um QTL e sim uma sugestão da presença dele. Para as análises do desenvolvimento da bacteriose, foram apresentados os intervalos de confiança somente para os picos que se apresentavam significativos para o limiar genômico ou para o cromossômico (Figuras 26 a 33). Entretanto, para as análises envolvendo as comparações das metodologias, foram apresentados os intervalos de confiança para cada metodologia, independentemente de serem significativos ou não (Figuras 34 e 35).

Um resumo de cada análise é apresentado, em forma de tabela, embaixo das Figuras 26 a 35. Em cada grupo de ligação são demonstrados os principais resultados referentes às variáveis mensuradas, por experimento, e os resultados obtidos por Lopes (2003). Nos gráficos, cada variável é ilustrada por uma cor. São demonstrados as posições dos maiores picos de LOD, os limiares genômico e cromossômico para, respectivamente, indicar a verdadeira ou sugestiva presença de QRL e efeito, o qual somente deve ser considerado se estatisticamente significativo. 


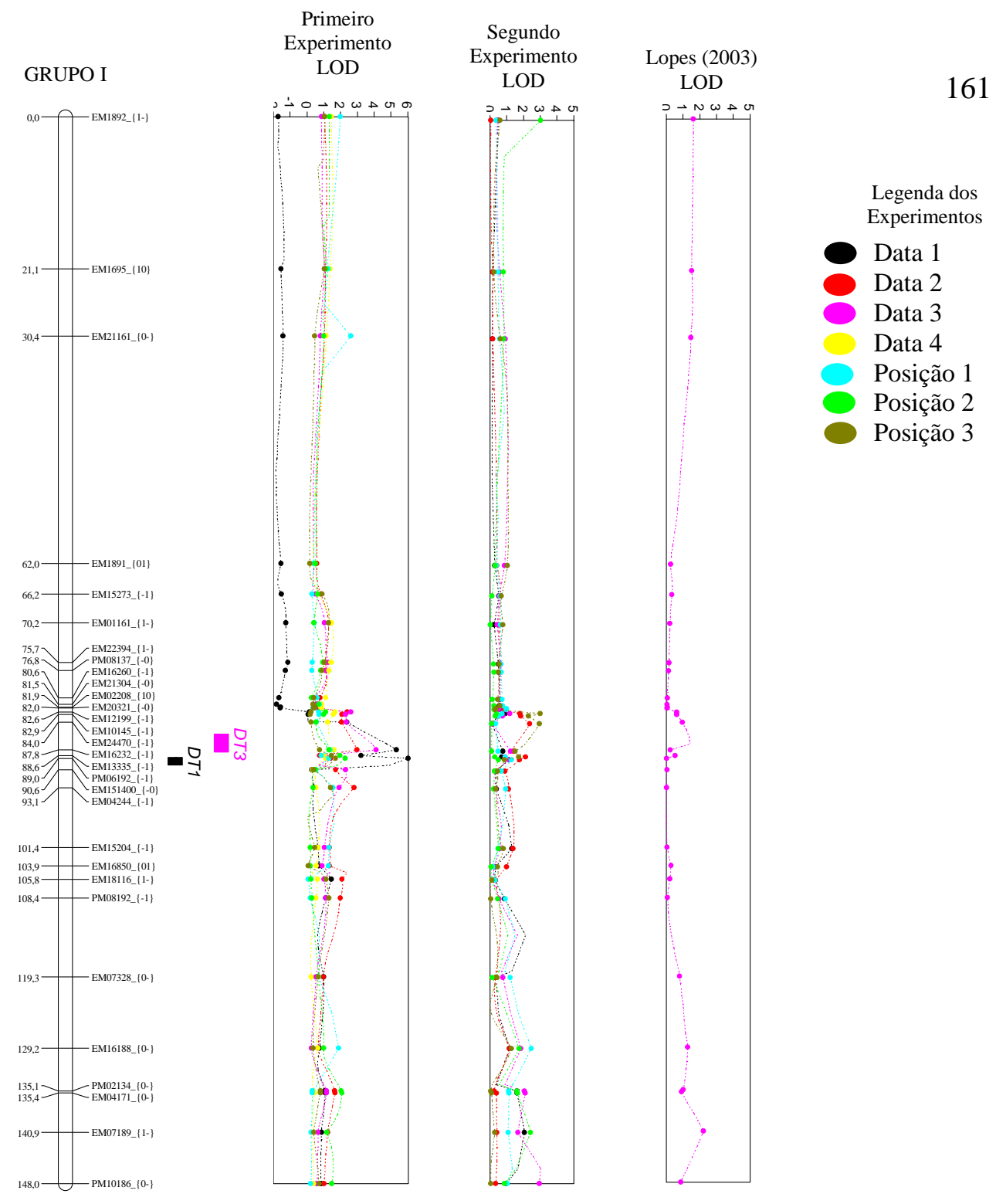

\begin{tabular}{cccccc}
\hline Variável $^{1 /}$ & LOD máximo & $\begin{array}{c}\text { Proporção da variação } \\
\text { fenotípica (\%) }\end{array}$ & Posição (cM) & Limiar genômico & Limiar cromossômico \\
\hline DT1 & 6,03 & 29,9 & 89,0 & 4,2 & 3,3 \\
DT2 & 2,98 & 20,5 & 87,8 & 4,2 & 3,3 \\
DT3 & 4,13 & 22,1 & 87,8 & 4,1 & 3,0 \\
DT4 & 1,68 & 19,8 & 82,6 & 4,3 & 3,1 \\
P1 & 2,62 & 64,0 & 30,4 & 4,3 & 3,3 \\
P2 & 2,27 & 11,9 & 89,0 & 4,2 & 3,3 \\
P3 & 1,70 & 7,2 & 89,0 & 4,3 & 3,4 \\
2DT1 & 2,14 & 20,5 & 113,4 & 4,2 & 3,2 \\
2DT2 & 2,38 & 29,6 & 84,0 & 4,2 & 3,2 \\
2DT3 & 3,02 & 50,6 & 145,9 & 4,0 & 3,2 \\
2P1 & 2,46 & 10,8 & 0,0 & 4,2 & 3,1 \\
2P2 & 3,02 & 60,3 & 82,6 & 4,2 & 2,9 \\
2P3 & 2,99 & 25,7 & 140,9 & 4,1 & 4,1 \\
Lopes & 2,22 & 18,0 & & \\
\hline 1/Primeiro experimento: DT1 =Data 1; DT2 =Data 2; DT3 =Data 3; DT4 =Data 4; P1 =Posição 1; P2 =Posição 2; P3 =Posição 3; \\
Segundo experimento: 2DT1 =Data 1; 2DT2 =Data 2; 2DT3 =Data 3; 2P1 =Posição 1; 2P2 =Posição 2; 2P3 =Posição 3
\end{tabular}

Figura 26 - Grupo I. Mapeamento de QRL à Xanthomonas axonopodis pv. passiflorae 

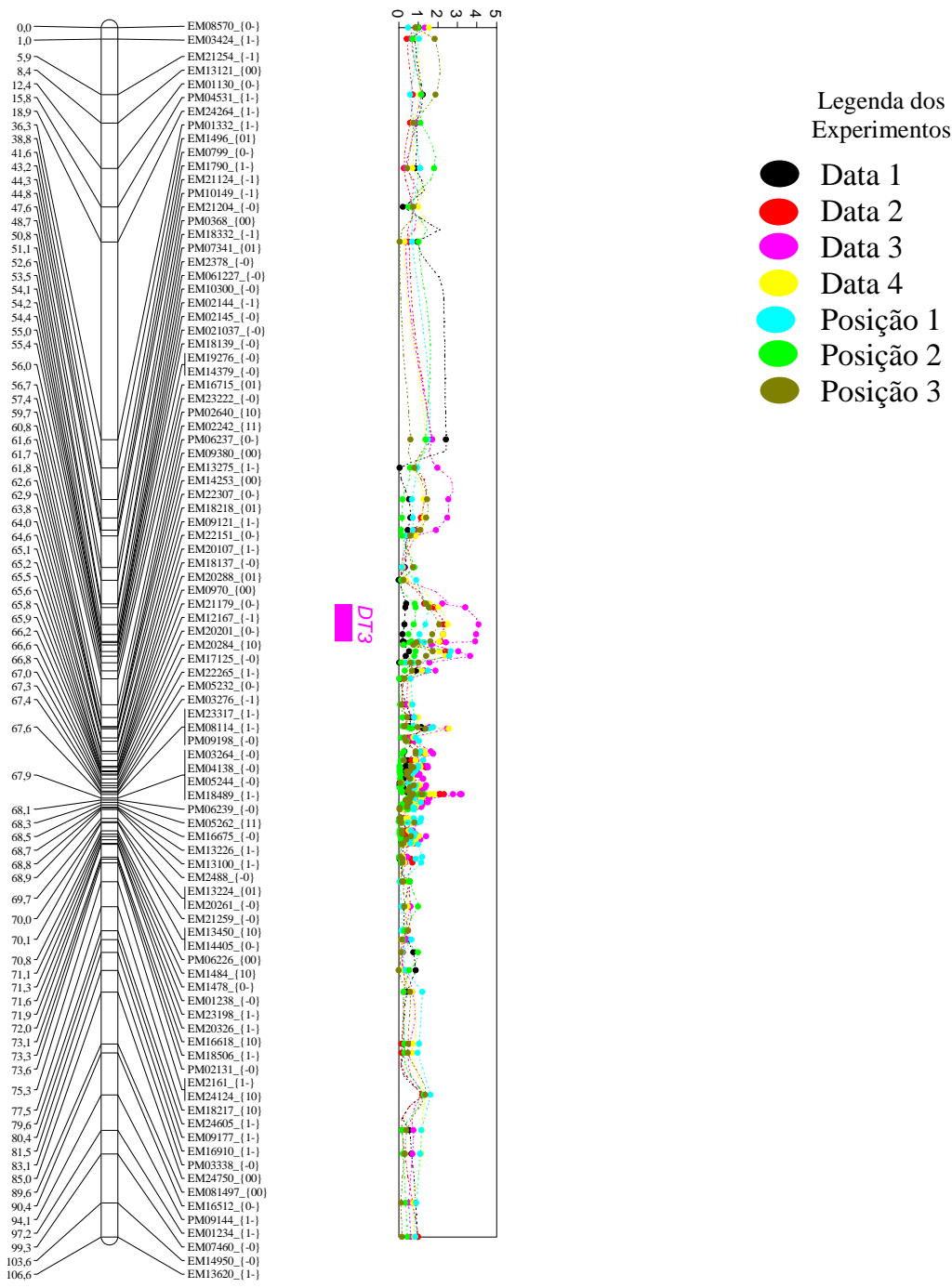

\begin{tabular}{cccccc}
\hline Variável $^{1 /}$ & LOD máximo & $\begin{array}{c}\text { Proporção da variação } \\
\text { fenotípica (\%) }\end{array}$ & Posição (cM) & Limiar genômico & Limiar cromossômico \\
\hline DT1 & 2,42 & 14,3 & 37,3 & 4,2 & 3,6 \\
DT2 & 2,56 & 8,9 & 55,4 & 4,2 & 3,6 \\
DT3 & 4,09 & 20,3 & 52,6 & 4,1 & 3,7 \\
DT4 & 2,57 & 10,5 & 61,8 & 3,6 \\
P1 & 2,67 & 13,3 & 55,0 & 4,3 & 3,6 \\
P2 & 1,86 & 10,1 & 11,4 & 3,6 \\
P3 & 2,11 & 13,5 & 4,0 & 4,2 & 3,7 \\
2DT1 & - & - & - & 4,3 & 3,7 \\
2DT2 & - & - & - & 4,2 & 3,6 \\
2DT3 & - & - & - & 4,2 & 3,7 \\
2P1 & - & - & - & 4,2 & 3,6 \\
2P2 & - & - & - & 4,2 & 3,7 \\
2P3 & - & - & - & 4,1 & 3,5 \\
Lopes & - & - & 4,1 & \\
\hline
\end{tabular}

${ }^{1 /}$ Primeiro experimento: DT1 =Data 1; DT2 =Data 2; DT3 =Data 3; DT4 =Data 4; P1 =Posição 1; P2 =Posição 2; P3 =Posição 3; Segundo experimento: 2DT1 =Data 1; 2DT2 =Data 2; 2DT3 =Data 3; 2P1 =Posição 1; 2P2 =Posição 2; 2P3 =Posição 3

Figura 27 - Grupo II. Mapeamento de QRL à Xanthomonas axonopodis pv. passiflorae 


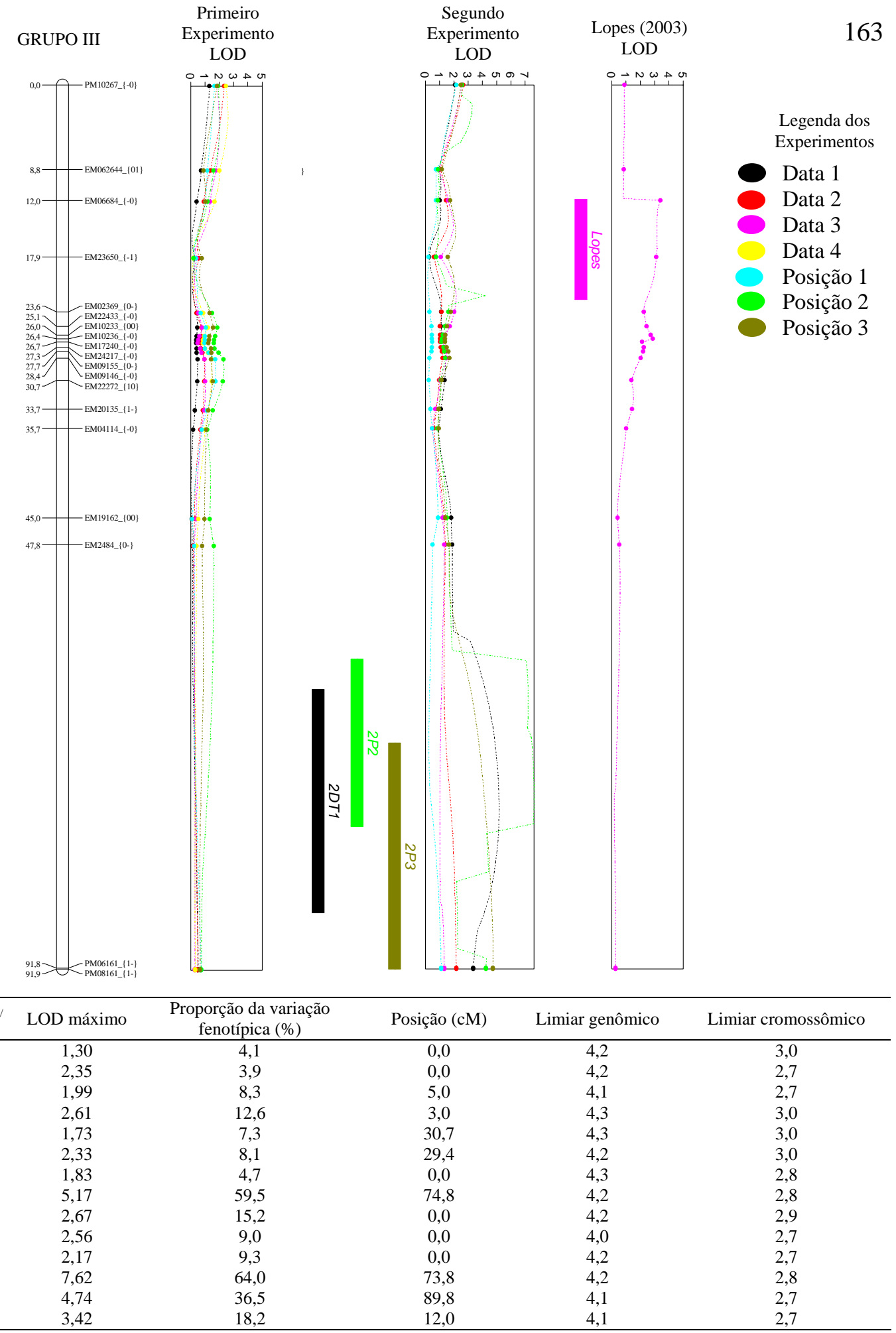

${ }^{1 /}$ Primeiro experimento: DT1 =Data 1; DT2 =Data 2; DT3 =Data 3; DT4 =Data 4; P1 =Posição 1; P2 =Posição 2; P3 =Posição 3; Segundo experimento: 2DT1 =Data 1; 2DT2 =Data 2; 2DT3 =Data 3; 2P1 =Posição 1; 2P2 =Posição 2; 2 P3 =Posição 3

Figura 28 - Grupo III. Mapeamento de QRL à Xanthomonas axonopodis pv. passiflorae 


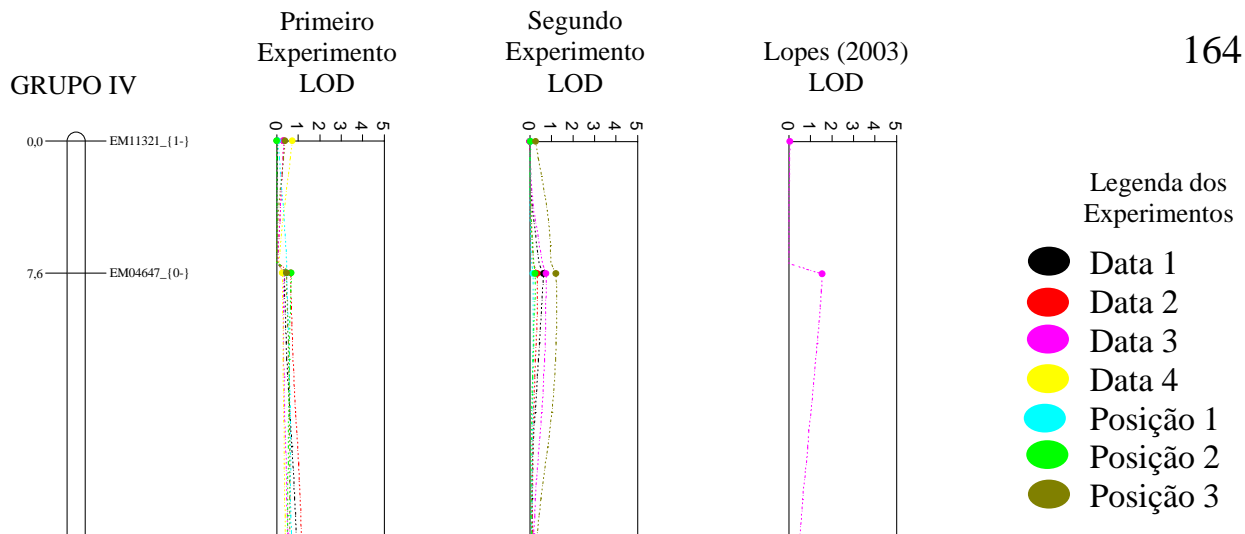

\begin{tabular}{cccccc} 
Variável $^{1 /}$ & LOD máximo & $\begin{array}{c}\text { Proporção da variação } \\
\text { fenotípica (\%) }\end{array}$ & Posição (cM) & Limiar genômico & Limiar cromossômico \\
\hline DT1 & 0,94 & 2,6 & 23,1 & 4,2 & 2,9 \\
DT2 & 1,24 & 8,8 & 24,1 & 4,2 & 3,0 \\
DT3 & 1,53 & 3,9 & 24,7 & 4,1 & 2,8 \\
DT4 & 1,13 & 5,0 & 44,6 & 4,3 & 3,0 \\
P1 & 3,38 & 15,2 & 24,7 & 2,9 \\
P2 & 1,76 & 7,5 & 46,2 & 4,3 & 3,1 \\
P3 & 1,05 & 3,3 & 31,6 & 4,2 & 3,0 \\
2DT1 & 0,96 & 3,2 & 31,7 & 4,3 & 2,0 \\
2DT2 & 1,25 & 5,9 & 31,7 & 4,2 & 3,0 \\
2DT3 & 0,96 & 5,7 & 24,7 & 4,0 & 3,1 \\
2P1 & 0,87 & 3,4 & 53,5 & 4,2 & 3,0 \\
2P2 & 0,87 & 4,2 & 24,7 & 3,2 & 3,0 \\
2P3 & 2,09 & 22,6 & 24,7 & 4,1 & 2,8 \\
Lopes & 1,55 & 12,1 & 7,6 & 4,1 & \\
\hline
\end{tabular}

${ }^{1 /}$ Primeiro experimento: DT1 =Data 1; DT2 =Data 2; DT3 =Data 3; DT4 =Data 4; P1 =Posição 1; P2 =Posição 2; P3 =Posição 3; Segundo experimento: 2DT1 =Data 1; 2DT2 =Data 2; 2DT3 =Data 3; 2P1 =Posição 1; 2P2 =Posição 2; 2P3 =Posição 3

Figura 29 - Grupo IV. Mapeamento de QRL à Xanthomonas axonopodis pv. passiflorae 


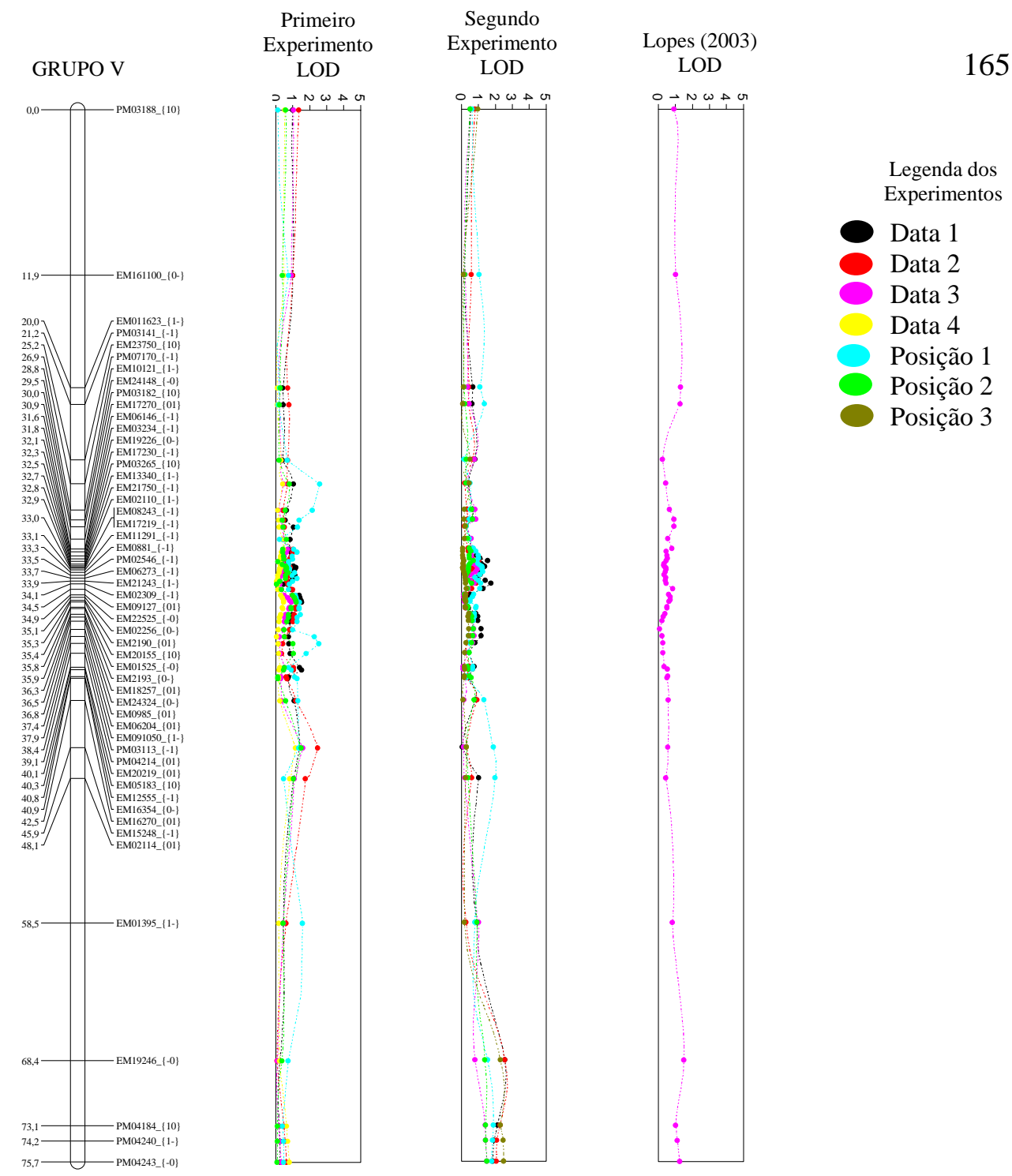

\begin{tabular}{|c|c|c|c|c|c|}
\hline Variável $^{1 /}$ & LOD máximo & $\begin{array}{l}\text { Proporção da variação } \\
\text { fenotípica (\%) } \\
\end{array}$ & Posição (cM) & Limiar genômico & Limiar cromossômico \\
\hline DT1 & 1,53 & 4,6 & 40,3 & 4,2 & 3,1 \\
\hline DT2 & 2,46 & 13,8 & 45,9 & 4,2 & 3,1 \\
\hline DT3 & 1,59 & 6,4 & 45,9 & 4,1 & 3,1 \\
\hline DT4 & 1,17 & 4,9 & 45,9 & 4,3 & 3,0 \\
\hline $\mathrm{P} 1$ & 2,58 & 17,5 & 26,9 & 4,3 & 3,0 \\
\hline $\mathrm{P} 2$ & 1,49 & 6,2 & 45,9 & 4,2 & 3,0 \\
\hline P3 & - & - & - & 4,3 & 3,2 \\
\hline 2DT1 & 2,63 & 16,0 & 69,4 & 4,2 & 3,2 \\
\hline 2DT2 & 2,70 & 14,5 & 70,4 & 4,2 & 3,1 \\
\hline 2DT3 & 1,50 & 5,8 & 75,7 & 4,0 & 2,9 \\
\hline 2P1 & 2,03 & 9,5 & 46,9 & 4,2 & 3,1 \\
\hline $2 \mathrm{P} 2$ & 1,50 & 5,2 & 75,7 & 4,2 & 3,1 \\
\hline 2P3 & 2,54 & 11,7 & 70,4 & 4,1 & 3,0 \\
\hline Lopes & 1,51 & 9,6 & 68,4 & 4,1 & 3,1 \\
\hline
\end{tabular}

Figura 30 - Grupo V. Mapeamento de QRL à Xanthomonas axonopodis pv. passiflorae 


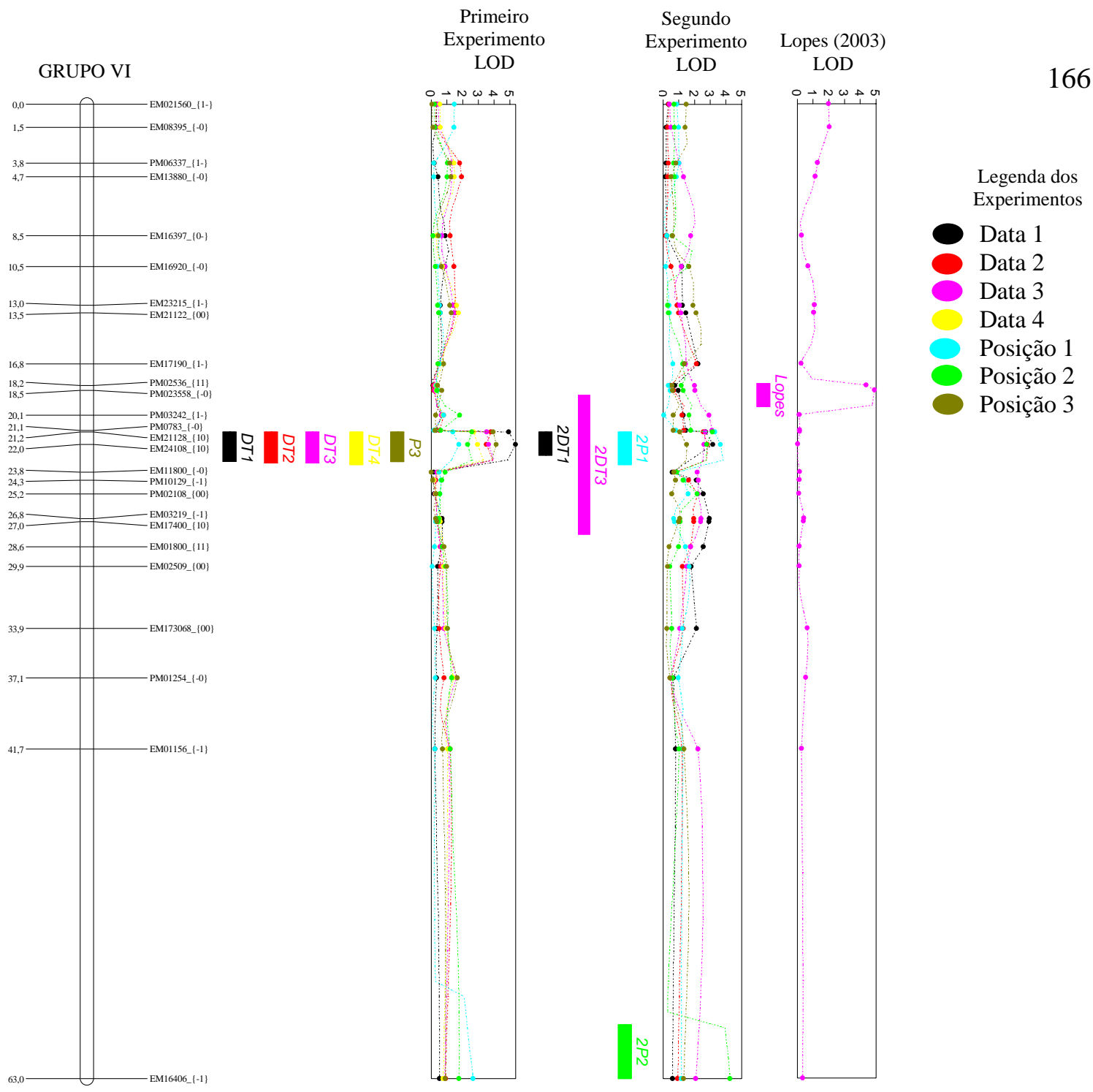

\begin{tabular}{|c|c|c|c|c|c|}
\hline Variável $^{1 /}$ & LOD máximo & $\begin{array}{l}\text { Proporção da variação } \\
\text { fenotípica (\%) }\end{array}$ & Posição (cM) & Limiar genômico & Limiar cromossômico \\
\hline DT1 & 5,38 & 8,7 & 22,0 & 4,2 & 3,0 \\
\hline DT2 & 3,91 & 24,4 & 23,0 & 4,2 & 2,9 \\
\hline DT3 & 4,00 & 22,9 & 23,0 & 4,1 & 2,8 \\
\hline DT4 & 3,32 & 16,4 & 23,0 & 4,3 & 3,0 \\
\hline $\mathrm{P} 1$ & 2,67 & 65,5 & 63,0 & 4,3 & 3,0 \\
\hline $\mathrm{P} 2$ & 2,59 & 13,2 & 23,0 & 4,2 & 3,0 \\
\hline P3 & 4,13 & 14,0 & 22,0 & 4,3 & 2,9 \\
\hline 2DT1 & 3,17 & 16,1 & 22,0 & 4,2 & 2,9 \\
\hline 2DT2 & 2,83 & 11,8 & 22,0 & 4,2 & 3,1 \\
\hline 2DT3 & 3,12 & 11,4 & 21,1 & 4,0 & 2,8 \\
\hline 2P1 & 3,81 & 11,5 & 23,0 & 4,2 & 3,0 \\
\hline $2 \mathrm{P} 2$ & 4,25 & 61,2 & 63,0 & 4,2 & 2,9 \\
\hline 2P3 & 2,43 & 12,9 & 14,5 & 4,1 & 3,0 \\
\hline Lopes & 4,92 & 17,6 & 18,5 & 4,1 & 2,9 \\
\hline
\end{tabular}

${ }^{1 /}$ Primeiro experimento: DT1 =Data 1; DT2 =Data 2; DT3 =Data 3; DT4 =Data 4; P1 =Posição 1; P2 =Posição 2; P3 =Posição 3; Segundo experimento: 2DT1 =Data 1; 2DT2 =Data 2; 2DT3 =Data 3; 2P1 =Posição 1; 2P2 =Posição 2; 2 P3 =Posição 3

Figura 31 - Grupo VI. Mapeamento de QRL à Xanthomonas axonopodis pv. passiflorae 


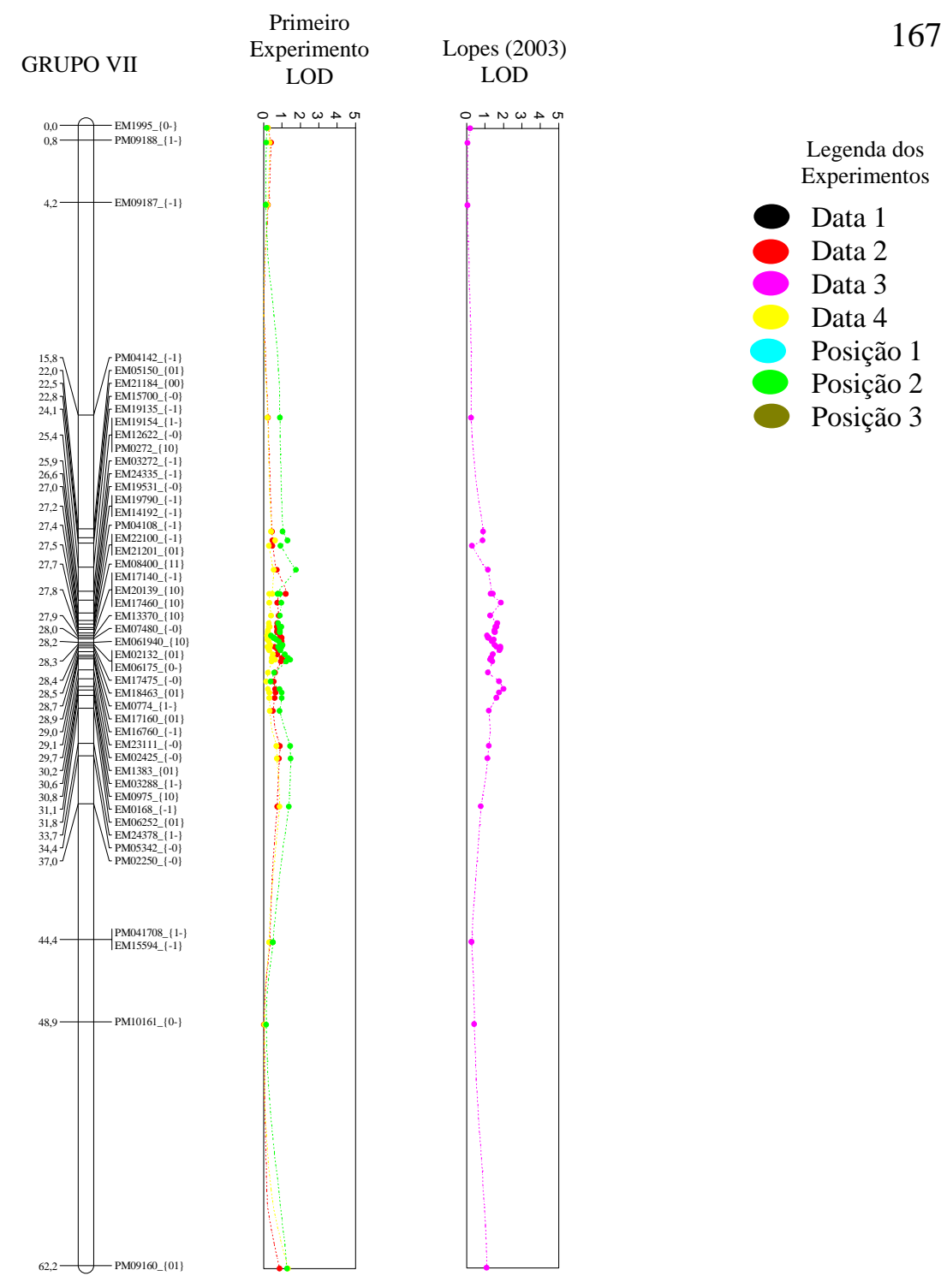

\begin{tabular}{cccccc}
\hline Variável $^{1 /}$ & LOD máximo & $\begin{array}{c}\text { Proporção da variação } \\
\text { fenotípica (\%) }\end{array}$ & Posição (cM) & Limiar genômico & Limiar cromossômico \\
\hline DT1 & - & - & - & 4,2 & 2,9 \\
DT2 & 1,22 & 1,5 & 25,4 & 4,2 & 2,9 \\
DT3 & - & - & - & 4,1 & 3,0 \\
DT4 & 1,33 & - & 62,2 & 4,3 & 3,0 \\
P1 & - & - & 4,3 & 3,1 \\
P2 & 1,76 & - & 24,1 & 4,2 & 3,0 \\
P3 & - & - & - & 4,3 & 2,9 \\
2DT1 & - & - & - & 4,2 & 3,0 \\
2DT2 & - & - & - & 4,2 & 2,9 \\
2DT3 & - & - & - & 4,0 & 3,0 \\
2P1 & - & - & - & 4,2 & 2,9 \\
2P2 & - & - & - & 4,2 & 2,9 \\
2P3 & - & 4,9 & 4,1 & 2,9 \\
Lopes & 2,01 & - & -1 & - \\
1/Primeiro experimento: DT1 =Data 1; DT2 2; DT3 =Data 3; DT4 =Data 4; P1 =Posição 1; P2 =Posição 2; P3 =Posição 3; \\
Segundo experimento: 2DT1 =Data 1; 2DT2 =Data 2; 2DT3 =Data 3; 2P1 =Posição 1; 2P2 =Posição 2; 2P3 =Posição 3
\end{tabular}

Figura 32 - Grupo VII. Mapeamento de QRL à Xanthomonas axonopodis pv. passiflorae 


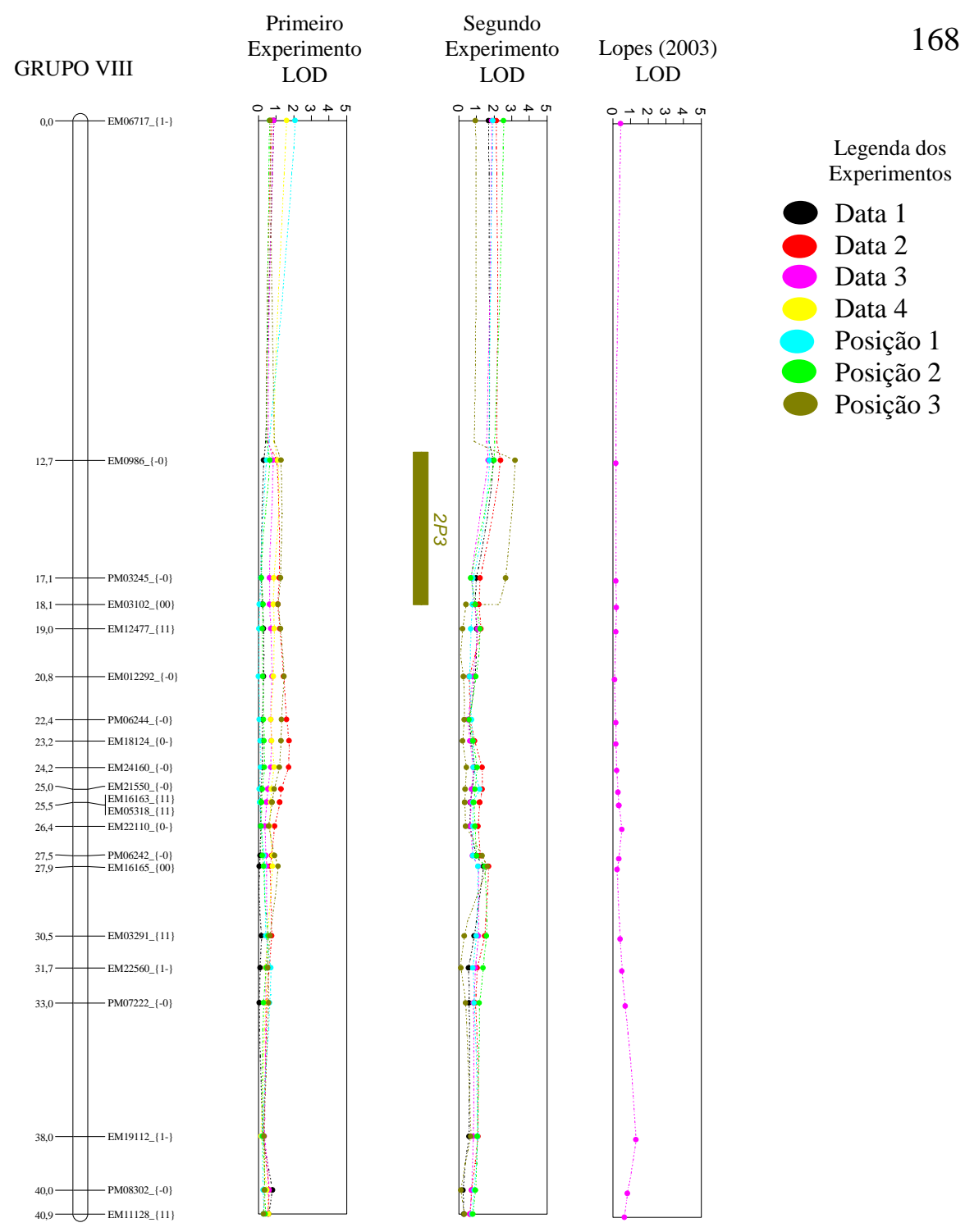

\begin{tabular}{|c|c|c|c|c|c|}
\hline Variável $^{1 /}$ & LOD máximo & $\begin{array}{l}\text { Proporção da variação } \\
\text { fentípica (\%) }\end{array}$ & Posição (cM) & Limiar genômico & Limiar cromossômico \\
\hline DT1 & 0,86 & 1,7 & 0,0 & 4,2 & 2,7 \\
\hline DT2 & 1,73 & 2,5 & 23,2 & 4,2 & 2,7 \\
\hline DT3 & 0,87 & 1,7 & 0,0 & 4,1 & 2,8 \\
\hline DT4 & 1,60 & 12,0 & 0,0 & 4,3 & 2,8 \\
\hline P1 & 2,09 & 12,7 & 0,0 & 4,3 & 2,7 \\
\hline P2 & 0,66 & 2,1 & 12,7 & 4,2 & 2,8 \\
\hline P3 & 1,45 & 4,5 & 20,8 & 4,3 & 2,7 \\
\hline 2DT1 & 1,97 & 11,5 & 12,7 & 4,2 & 2,8 \\
\hline 2DT2 & 2,36 & 10,6 & 12,7 & 4,2 & 2,6 \\
\hline 2DT3 & 1,81 & 10,7 & 0,0 & 4,0 & 2,6 \\
\hline 2P1 & 1,93 & 7,8 & 0,0 & 4,2 & 2,7 \\
\hline 2P2 & 2,55 & 26,7 & 0,0 & 4,2 & 2,7 \\
\hline $2 \mathrm{P} 3$ & 3,19 & 14,9 & 12,7 & 4,1 & 2,7 \\
\hline Lopes & 1,30 & 2,8 & 38,0 & 4,1 & 2,6 \\
\hline
\end{tabular}

Figura 33 - Grupo VIII. Mapeamento de QRL à Xanthomonas axonopodis pv. passiflorae 
Os resultados de mapeamento de locos quantitativos demonstraram que o uso de uma só data para mensuração do tamanho de lesão levaria a perdas de informações para a detecção de QRL. Ao utilizar diferentes datas, em um mesmo experimento, houve uma quantidade maior de dados que possibilitaram maiores chances de deteç̧ão e a realização de análises mais consistentes. De acordo com a data de avaliação e/ou idade da folha, foi possível encontrar resultados distintos, como a obtenção dos mesmos QRL com diferentes efeitos ou, até mesmo, QRL alocados em grupos distintos. Um resumo dos resultados de mapeamento, envolvendo os dois experimentos e os dados obtidos por Lopes (2003), está apresentado na Tabela 24.

Tabela 24. Mapeamento de QRL envolvendo os dois experimentos e os dados obtidos por Lopes (2003), grupos de ligação, posição correspondente, respectivo intervalo e teste de marca simples

\begin{tabular}{|c|c|c|c|c|c|}
\hline Variável & Situação $^{1 /}$ & $\begin{array}{l}\text { Grupo de } \\
\text { ligação }\end{array}$ & $\begin{array}{l}\text { Posição no } \\
\text { mapa (cM) }\end{array}$ & $\begin{array}{c}\text { Efeito do QRL } \\
(\%)\end{array}$ & Intervalo $^{2 /}$ \\
\hline DT1 & Evidência & I & 89,0 & 29,9 & PM06192 ${ }^{\mathrm{ns}}$ \\
\hline DT3 & Evidência & I & 87,8 & 22,1 & EM16232 ${ }^{\mathrm{ns}}$ \\
\hline DT3 & Sugestão & II & 52,6 & 20,3 & EM2378 * \\
\hline 2DT1 & Evidência & III & 74,8 & 59,5 & EM$_{2484}{ }^{\text {ns }} /$ PM06161 ${ }^{\text {ns }}$ \\
\hline $2 \mathrm{P} 2$ & Evidência & III & 73,8 & 64,0 & EM$_{2484}{ }^{\text {ns }} /$ PM06161 $1^{\text {ns }}$ \\
\hline 2P3 & Evidência & III & 89,8 & 36,5 & EM$_{2484}{ }^{\text {ns }} /$ PM06161 ${ }^{\text {ns }}$ \\
\hline Lopes (2003) & Sugestão & III & 12,0 & 18,2 & EM06684 * \\
\hline $\mathrm{P} 1$ & Sugestão & IV & 24,7 & 15,2 & EM12182 * \\
\hline DT1 & Evidência & VI & 22,0 & 8,7 & EM24108 * \\
\hline DT2 & Sugestão & VI & 23,0 & 24,4 & EM24108 */ EM11800* \\
\hline DT3 & Sugestão & VI & 23,0 & 22,9 & EM24108 */ EM11800 ns \\
\hline DT4 & Sugestão & VI & 23,0 & 16,4 & EM24108 */ EM11800 ${ }^{\text {ns }}$ \\
\hline P3 & Sugestão & VI & 22,0 & 14,0 & EM24108 * \\
\hline 2DT1 & Sugestão & VI & 22,0 & 16,1 & EM24108* \\
\hline 2DT3 & Sugestão & VI & 21,1 & 11,4 & PM0783 * \\
\hline 2P1 & Sugestão & VI & 23,0 & 11,5 & EM24108 */ EM11800* \\
\hline $2 \mathrm{P} 2$ & Evidência & VI & 63,0 & 61,2 & EM16406 ${ }^{\mathrm{ns}}$ \\
\hline Lopes (2003) & Evidência & VI & 18,5 & 17,6 & PM023558 * \\
\hline $2 \mathrm{P} 3$ & Sugestão & VIII & 12,7 & 14,9 & EM0986 * \\
\hline
\end{tabular}

${ }^{1 /}$ Evidência = significativo considerando-se o limiar genômico; Sugestão = significativo considerando-se o limiar cromossômico; ${ }^{2 /}$ Alguns picos de LOD apresentam-se posicionados sobre a marca; * $\mathrm{e}^{\text {ns: }}$ significativo e não significativo, ao nível de 5\% de probabilidade, respectivamente

Para cada grupo de ligação, a distribuição dos escores foi diferente de acordo com a variável considerada. Nas situações em que os maiores picos de LOD, das 
diferentes variáveis, se apresentaram próximos, foi considerado que há apenas um QRL, sendo esta pequena diferença de posicionamento explicada por serem análises distintas. Assim, os picos detectados no Grupo VI, nas posições 18,5 cM (Lopes, 2003), 21,1 cM (2DT3), 22,0 cM (DT1, P3 e 2DT1) e 23,0 cM (DT2, DT3, DT4 e 2P1), considerou-se tratarem-se de um mesmo QRL, com diferentes efeitos, de acordo com a variável em questão.

O Grupo I apresentou evidências de QRL (Figura 26). Este resultado deve ser avaliado com cautela, pois se tratam, possivelmente, de QRL fantasmas. Este é o caso, por exemplo, do marcador PM06192 e sua associação com a variável DT1. Como na análise de marcas simples não é controlada a variação em outras posições do genoma, o efeito do loco quantitativo, em outra região, pode fazer uma marca mais distante mostrar-se significativa. Da mesma forma, poderia ocorrer o inverso (Lynch \& Walsh, 1998). Vale relatar que a presença de “LOD scores” negativos, detectada no Grupo I, no primeiro experimento, significa apenas a ausência de QRL no local.

O QRL detectado no Grupo II, ligado ao marcador EM2378, foi igualmente encontrado por Lopes (2003) (Figura 27). Verifica-se que este QRL explica 20,3\% da variância fenotípica, com base na variável DT3, sendo proveniente do genitor IAPAR123 e está em associação com a marca. Neste caso, há a possibilidade de se realizar seleção para resistência à bacteriose assistida por este marcador.

No Grupo III há evidências de QRL, quando se consideram as variáveis 2DT1, 2P2 e 2P3, no segundo experimento. Um deles está localizado em uma região que apresenta poucos marcadores. As marcas que flanqueiam este QRL (EM2484 e PM06161), pelo teste de marca simples, foram não significativas, indicando a ocorrência de recombinação entre as marcas e o QRL. Portanto, não é aconselhável realizar seleção com base nessas marcas franqueadoras. Os dados fenotípicos obtidos por Lopes (2003) sugerem a existência de outro QRL na posição do marcador EM06684 (12,0cM), oriundo do genitor IAPAR-123 (dados não relatados). Com base no teste de marca simples verifica-se que esta marca apresenta-se em repulsão com o QRL não sendo justificável realizar a seleção assistida (Figura 28). 
Nas situações em que o marcador encontrava-se em repulsão com o QRL, o fenótipo molecular nulo (ausência de amplificação do DNA e, portanto, da banda no gel) foi responsável por conferir maior grau de tolerância à moléstia. Caso este marcador fosse codominante, isso não teria acontecido. Caso existir uma marca mais próxima ao loco em questão, em associação ao QRL, esta poderia ser investigada. Entretanto, podem ocorrer situações em que as marcas próximas sejam não significativas quanto ao QRL, podendo este fato ser devido a recombinações entre o QRL e o loco do marcador (Liu, 1998). O mesmo pode ser descrito para o QRL detectado no Grupo IV, o qual apresentase ligado ao marcador EM12182, proveniente do genitor IAPAR-06, e que também está em repulsão com o QRL, sendo as marcas mais próximas não significativas (Figura 29).

Recomenda-se a realização de novos estudos referentes à especificidade do QRL detectado no Grupo III, pois, no segundo experimento, foram utilizados dois isolados bacterianos provenientes do trabalho realizado por Nakatani, (2001). Este segundo ensaio foi conduzido no sentido de prever o que poderia acontecer no campo, onde se pressupõe haver mais de um isolado atacando o pomar. Como dito, os QRL podem se comportar como predito na teoria clássica gene-a-gene, a qual foi constatada em batata em estudos para resistência ao nematóide de cisto, Globodera pallida, sendo detectado um QRL para cada um dos dois determinantes avirulentos utilizados por Van der Voort et al. (2000).

Resultados muito semelhantes aos apresentados por Lopes (2003) ocorreram quando se analisou o Grupo VI (Figura 31), embora o QRL detectado por este autor e o aqui encontrado, considerando o primeiro experimento, não estejam localizados exatamente na mesma posição. Isso pode ser explicado pelo fato de haver somente 69 indivíduos comuns aos dois estudos. Verifica-se que esse QRL provavelmente esteja presente nos dois genitores, pois além da marca bi-parental EM24108 estar fortemente ligada ao QRL, as marcas do tipo monoparentais de ambos genitores também se apresentaram significativas (Tabela 20).

Considerando o segundo experimento, o Grupo VI também mostra um pico significativo, ao limiar genômico, na posição 63,0 cM, justamente sobre o marcador 
EM16406. Porém esta marca, pelo teste de marca simples, apresenta-se como não significativa; provavelmente, trata-se de um QRL fantasma.

O QRL encontrado no Grupo VIII, com base na variável fenotípica 2P3, identificado a partir da média do avanço das lesões na folha 3, está localizado sobre a marca EM0986, na posição 12,7cM e é proveniente do genitor IAPAR-123 (Figura 33).

Os QRL do Grupo II e VI ligados aos marcadores EM2378 e EM24108, respectivamente, foram confirmados. Seria recomendável conduzir experimentos no campo, ou seja, cultivando a população de mapeamento em uma área infestada com a bacteriose. Isso possibilitaria verificar, de forma mais confiável, a existência desses QRL podendo, então, serem considerados estáveis e úteis para os programas de melhoramento.

Recomenda-se realizar a seleção assistida, com chances de sucesso, somente para os QRL detectados no Grupo II, com base no marcador EM2378, no Grupo VI, com base no marcador EM24108 e no Grupo VIII, tendo como referência a marca EM0986.

Foram realizadas comparações teóricas entre uma seleção fenotípica de 20\% (21 indivíduos) da população e seleções com base nas marcas moleculares (Tabela 25).

Tabela 25. Comparações entre seleção com base no fenótipo, para cada variável, e com base nos marcadores moleculares

\begin{tabular}{lccc}
\hline & Variável DT1 & Variável DT3 & Variável 2P3 \\
\hline Marca ligada ao QRL & EM24108 & EM2378 & EM0986 \\
Indivíduos com a marca ${ }^{1 /}$ & 19 & 15 & 13 \\
Média geral $\left(\mathrm{cm}^{2}\right)$ & 3,342 & 11,694 & 3,358 \\
Média $\left(\mathrm{cm}^{2}\right)$ dos indivíduos com a banda (alelo) & 3,133 & 10,658 & 3,173 \\
Média (cm ${ }^{2}$ ) dos indivíduos que apresentam as três bandas ${ }^{2 /}$ & 3,058 & 10,455 & 2,907 \\
Indivíduos da seleção fenotípica apresentando as três bandas & 3 & 5 & 6 \\
\hline${ }^{1 /}$ Número de indivíduos selecionados com base no fenótipo e que também apresentam o respectivo alelo \\
ligado ao QRL; ${ }^{2 /}$ Apenas 14 indivíduos apresentaram, simultaneamente, os três alelos (bandas)
\end{tabular}

Considerando cada QRL, verifica-se que a presença dos alelos ligados acarreta em uma redução nas médias do tamanho das lesões. E considerando os indivíduos que apresentam os três alelos ligados aos QRL, a redução foi um pouco maior. A ocorrência 
de dados perdidos prejudicou esse tipo de comparação, pois não houve como classificar certos indivíduos, prejudicando as estimativas das médias. Nota-se que não houve grandes reduções, além da herdabilidade da característica ser baixa. Não se espera obter ganhos genéticos significativos, em curto prazo, com base em marcadores dominantes. Entretanto, os resultados do presente estudo dão uma idéia da herança da resistência à bacteriose. Há pelo menos três QRL envolvidos, além de outros genes de menor efeito que, provavelmente, estão associados à resposta da população à inoculação por Xanthomonas axonopodis pv. passiflorae.

Comparando-se as três metodologias de mensuração das lesões quanto aos resultados das análises de mapeamento, foi verificado que elas se mostraram igualmente úteis para realizar as mensurações, em ambos experimentos (Figuras 34 e 35).

As metodologias foram igualmente eficientes em detectar QRL no Grupo VI, na posição 23 cM (Figura 34). As barras que representam o intervalo de confiança de 95\% para o posicionamento do QRL estão localizadas no mesmo sítio, a despeito da metodologia usada. Os dados fenotípicos, obtidos aos 17 dias após a inoculação, forneceram estimativas de LOD máximo que ultrapassaram o respectivo limiar cromossômico. Lopes (2003) também identificou uma região (QRL) associada a esse grupo, explicando 15,8\% da variação fenotípica, mais precisamente ligada ao marcador PM023558, o qual está situado distante apenas a 4,5 cM do ponto aqui encontrado. O resultado obtido neste trabalho fornece maior consistência para a seleção assistida em programas de melhoramento para resistência à bacteriose do maracujazeiro. Estas considerações referem-se aos dados oriundos do primeiro experimento.

Os dados coletados no segundo experimento demonstraram que as amplitudes dos intervalos de confiança para o posicionamento dos QRL foram maiores (Figura 35). Verifica-se a necessidade de inserir novos marcadores nessa região e de utilizar uma população maior, de forma a obter maior precisão.

Quanto à unidade de avaliação para mensuração da resistência à bacteriose, pode-se usar tanto as porcentagens das folhas lesionadas, quanto as próprias áreas das lesões, em $\mathrm{cm}^{2}$, obtidas depois de contornar as lesões. Os resultados das análises de 
mapeamento, obtidos com base nos dados do primeiro experimento, demonstram que não há diferenças quanto às unidades de avaliação (Figura 34).

Os resultados obtidos neste trabalham corroboram os obtidos por Lopes (2003). Novos experimentos, envolvendo uma população maior e até mesmo novos isolados poderão ser úteis para um melhor entendimento da natureza genética da resistência à bacteriose do maracujazeiro. Avaliações a campo também serão úteis à pesquisa e ao melhoramento.

Dentre os próximos passos, que já vêm sendo desenvolvidos pelo Laboratório de Biologia Celular e Molecular de Plantas da ESALQ/USP, o uso de marcadores codominantes como os microssatélites, serão muito úteis para evitar viés da distância entre as marcas e a ordenação das mesmas. Também, os marcadores RAPD usados por Carneiro et al. (2002), para a construção do primeiro mapa genético de Passiflora, serão agregados para a formação de um mapa único. Alguns desses marcadores podem estar em associação aos supostos QRL detectados nos Grupos III e IV, nos quais as marcas AFLP se mostraram ligadas em repulsão.

Além disso, as seqüências de DNA, correspondentes a esses marcadores RAPD e AFLP, poderão ser utilizadas para o desenvolvimento de sondas, visando à atribuição dos grupos de ligação aos cromossomos da espécie.

Neste trabalho, mais um passo foi dado no sentido de conhecer melhor o mecanismo de resistência à bacteriose do maracujazeiro. Muitas questões ainda estão por ser respondidas e até mesmo criadas. Como não se conhece a natureza dos QRL (genes candidatos), acredita-se que estudos envolvendo diferentes datas de mensuração e idades fisiológicas das plantas poderão fornecer informações quanto aos genes de resposta durante a batalha patógeno versus hospedeiro. 


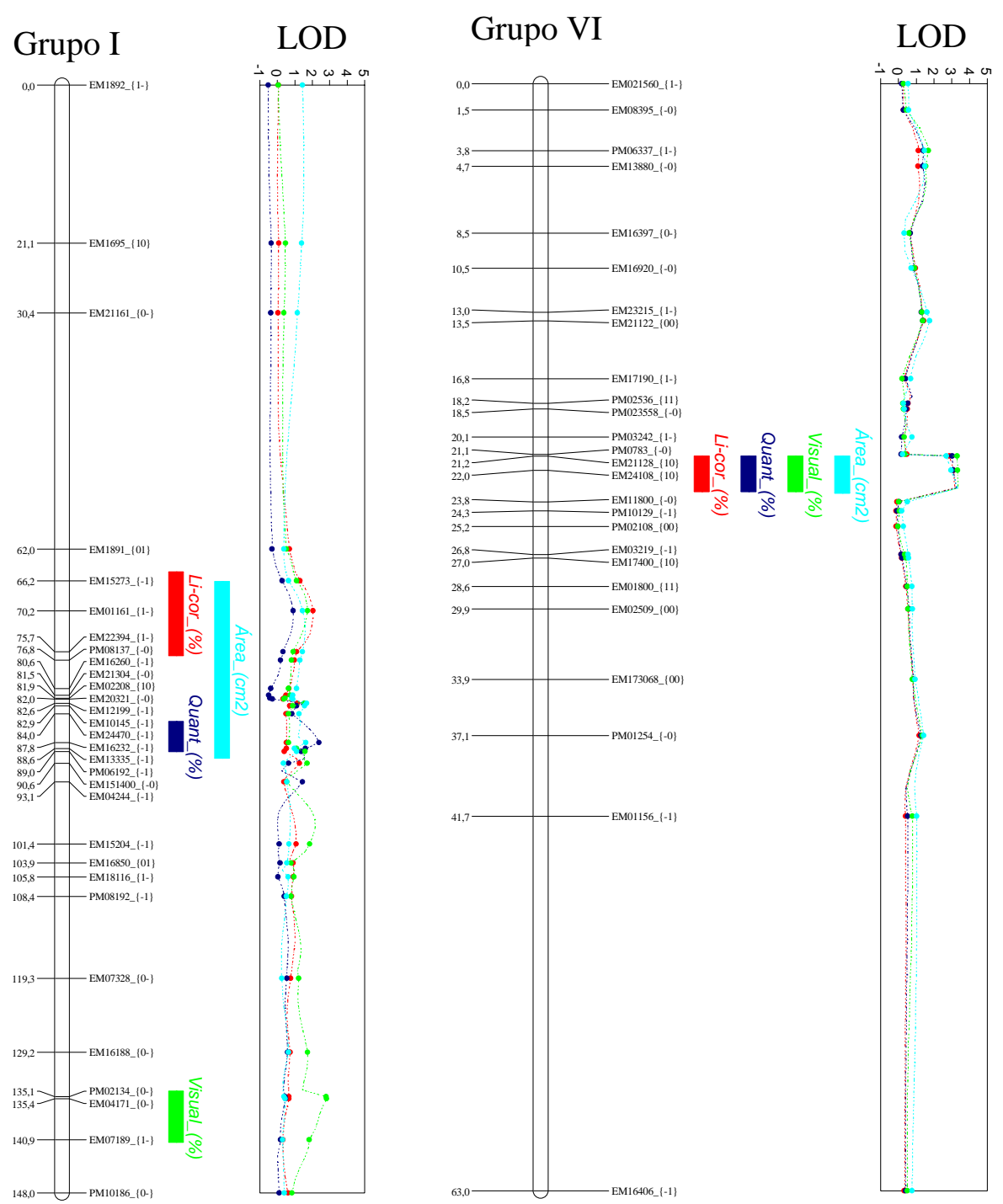

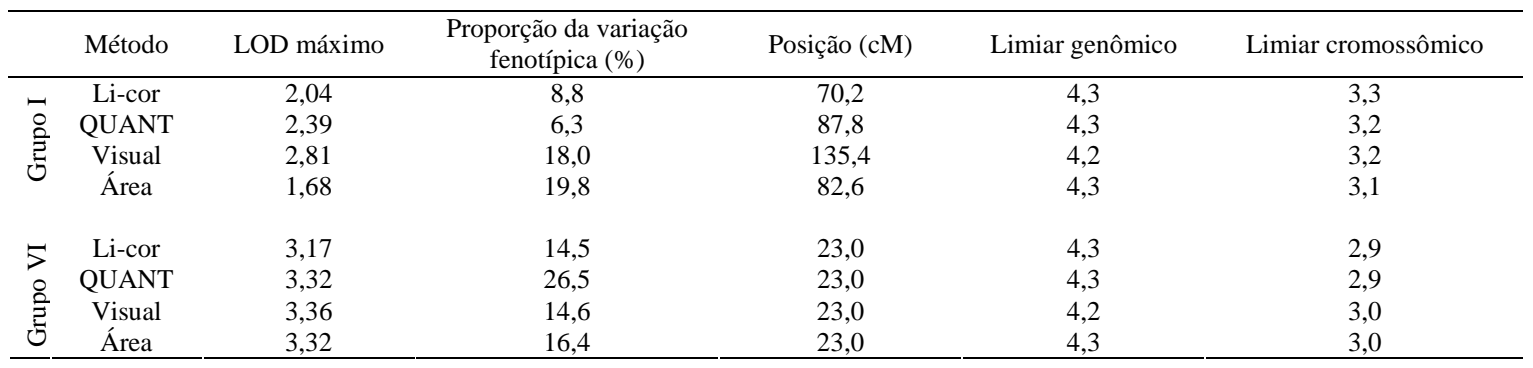

Figura 34 - Comparação entre as metodologias para o mapeamento de QRL à Xanthomonas axonopodis pv. passiflorae para os grupos de ligação I e VI, do primeiro experimento 
Grupo I

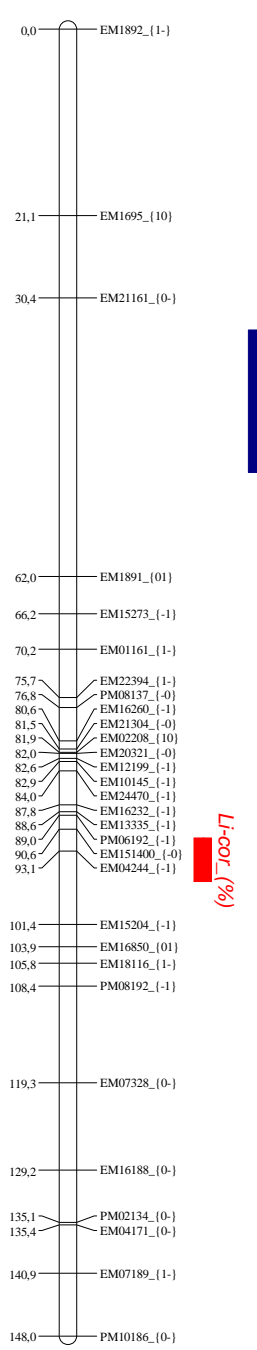

LOD

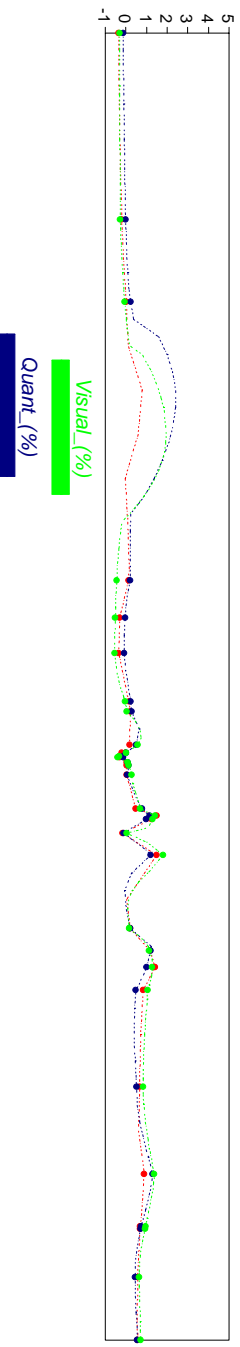

Grupo III

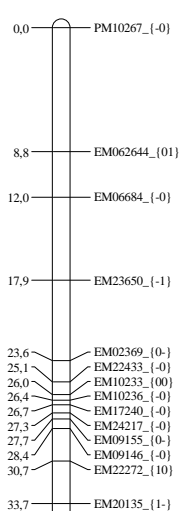

33,7- EM20135_

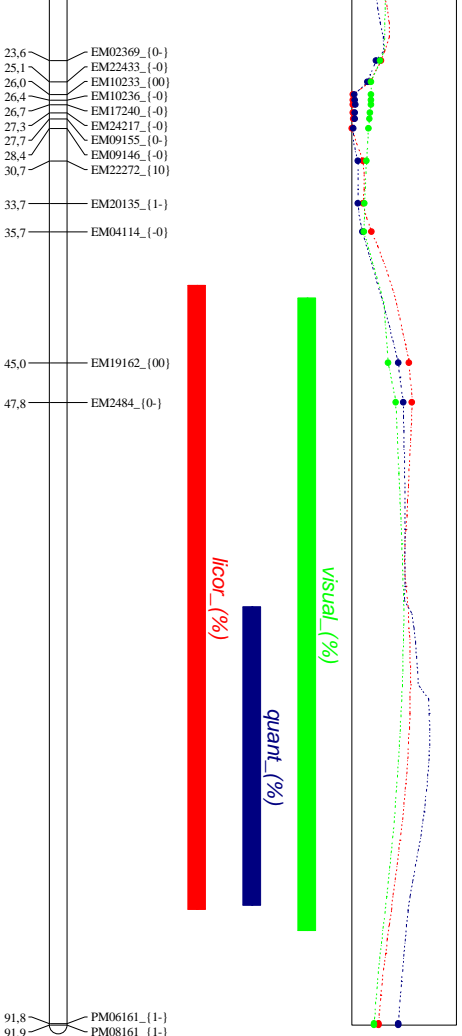

LOD

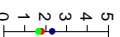

ind
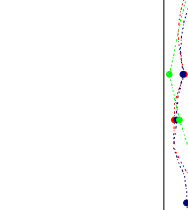

91.9

\begin{tabular}{|c|c|c|c|c|c|c|}
\hline & Método & LOD máximo & $\begin{array}{c}\text { Proporção da variação } \\
\text { fenotípica (\%) }\end{array}$ & Posição (cM) & Limiar genômico & Limiar cromossômico \\
\hline \multirow{3}{*}{ 灾 } & Li-cor & 1,48 & 7,6 & 88,6 & 4,2 & 3,1 \\
\hline & QUANT & 2,41 & 45,8 & 40,4 & 4,1 & 3,1 \\
\hline & Visual & 1,95 & 51,4 & 45,4 & 4,1 & 3,1 \\
\hline \multirow{3}{*}{ 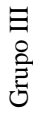 } & Li-cor & 2,89 & 10,7 & 47,8 & 4,2 & 2,8 \\
\hline & QUANT & 3,72 & 68,3 & 70,8 & 4,1 & 2,8 \\
\hline & Visual & 3,28 & 42,5 & 67,8 & 4,1 & 2,8 \\
\hline
\end{tabular}

Figura 35 - Comparação entre as metodologias para o mapeamento de QRL à Xanthomonas axonopodis pv. passiflorae para os grupos de ligação I e III, do segundo experimento 


\section{CONCLUSÕES}

Nas condições em que os experimentos foram conduzidos, os resultados permitem as seguintes conclusões:

É viável proceder à integração de mapas de ligação de maracujá-amarelo, construídos a partir da estratégia "duplo pseudocruzamento teste” e marcadores AFLP de segregação mendeliana 1:1, a partir de marcadores que segregam 3:1;

A construção de mapas de ligação é prejudicada quando se utilizam somente marcadores dominantes;

Metodologias de mensuração de lesões provocadas pela inoculação de plantas de maracujá-amarelo com $X$. axonopodis pv. passiflorae conduzem a uma classificação distinta dos genótipos da população segregante quanto à resistência à bacteriose, porém levam a resultados equivalentes quanto ao mapeamento de QRL;

Com base em dois experimentos distintos, usando-se um e dois isolados de Xanthomonas axonopodis pv. passiflorae, respectivamente, pode-se concluir que a herança do caráter resistência à bacteriose é do tipo poligênica e há, pelo menos, 3 locos quantitativos (QRL) envolvidos;

Datas de avaliação e/ou idades das folhas, considerando-se um mesmo experimento, interferem na detecção de QRL com diferentes efeitos ou, até mesmo, levam à atribuição de QRL a diferentes grupos de ligação. 


\section{REFERÊNCIAS BIBLIOGRÁFICAS}

AKAMINE, E.K.; G. GIROLAMI. Pollination and fruit set in the yellow passion fruit. University of Hawaii, Honolulu. Agricultural Experiment Station, Technical Bulletin, n. 39, 44 p. 1959.

ALBUQUERQUE, A.S. Seleção de genitores e híbridos em maracujazeiro (Passiflora edulis Sims). Viçosa: UFV, 2001. 90p. Tese (Doutorado) - Universidade Federal de Viçosa.

ALONSO-BLANCO, C.; PEETERS, A.J.M.; KOORNNEEF, M.; LISTER, C.; DEAN, C.; VAN DEN BOSH, N.; POT, J.; KUIPER, M.T.R. Development of an AFLP based linkage map of Ler, Col and Cvi Arabdopsis thaliana ecotypes and construction of a Ler/Cvi recombinant inbred line population. Plant Journal, v. 14, p. 259 - 271, 1998.

AMUGUNE, N.O.; GOPALAN, H.N.B.; BYTEBIER, B. Leaf disc regeneration of passion fruit. African Crop Science Journal, v. 1, p. 99 - 104. 1993.

ATIENZA, S.G.; SATOVIC, Z.; PETERSEN, K.K.; DOLSTRA, O.; MARTÍN, A. Preliminary genetic linkage map of Miscanthus sinensis with RAPD markers. Theoretical and Applied Genetics, v. 105, n. 6/7, p. 946 - 952, 2002.

BAILEY, N.T.J. Introduction to the mathematical theory of genetic linkage. London: Oxford University Press, 1961. 298 p.

BAKER, B.; ZAMBRYSKI, P.; STASKAWICZ, B.; DINESH-KUMAR, S.P. Signaling in plant-microbe interactions. Science, v. 276, p.726 - 733, 1997. 
BARBIN, D. Componentes de variância: teoria e aplicações. 2.ed. Piracicaba: FEALQ, 1993. 120 p.

BARBOSA, L.S. Resistência de Passiflora spp. a Xanthomonas campestris pv. passiflorae e deteç̧ão do patógeno em sementes. Viçosa, MG, 1995. 66p. Dissertação (Mestrado) - Universidade Federal de Viçosa.

BEARZOTI, E. Mapeamento de QTL In: PINHEIRO, J.B., CARNEIRO, I.F. (Eds.) Análise de QTL no melhoramento de plantas. Goiânia: FUNAPE, 2000. p. 63 224.

BEATTIE, G.A.; LINDOW, S.E. Bacterial colonization of leaves: a spectrum of strategies. Phytopathology, v. 89, p. 353 - 359, 1999.

BECKER, J.; VOS, P.; KUIPER, M.; SALAMINI, F.; HEUN M. Combined mapping of AFLP and RFLP markers in barley. Molecular Genetics and Genomics, v. 259, p. $65-73,1995$.

BRAGA, M.F.; JUNQUEIRA, N.T.V. Uso potencial de outras espécies do gênero Passiflora. Informe Agropecuário. v. 21, n. 206, p. 72 - 75, 2000.

BRUCKNER, C.H.; CASALI, V.W.D.; MORAES, C.F. de; REGAZZI, A.J.; SILVA, E.A.M. da. Self-incompatibility in passion fruit (Passiflora edulis Sims). Acta Horticulturae, n. 370, p. 45 - 57, 1995.

BRUCKNER, C.H.; MELETTI, L.M.M.; OTONI, W.C.; ZERBINI JÚNIOR, F.M. Maracujazeiro. In: Bruckner, C.H. (ed.). Melhoramento de Fruteiras Tropicais. Viçosa: UFV, 2002. cap. 13, p. $373-410$.

BRUCKNER, C.H.; OTONI, W.C. Hibridação em maracujá. In: BORÉM, A. (Ed.). Hibridação artificial de plantas. Viçosa: UFV, 1999. p. 379 - 399.

BRUCKNER, C.H.; SILVA, M.M.; FALLEIRO, T.M.; ANDRADE, B.B.; MOREIRA, A.E. Viabilidade do pólen de maracujazeiro (Passiflora edulis f. flavicarpa) sob diferentes condições de armazenamento. Revista Ceres, v. 47, n. 273, p. 1 - 9, 2000. 
BUBECK, D.M.; GOODMAN, M.M.; BEAVIS, W.D.; GRANT, D. Quantitative trait loci controlling resistance to gray leaf spot in maize. Crop Science, v. 33, p. 838 847, 1993.

CAMARGO, L.E.A. Análise genética da resistência e da patogenicidade. In: BERGAMIN FILHO, A.; KIMATI, H.; AMORIM, L. (Eds.). Manual de Fitopatologia: princípios e conceitos. São Paulo: Agronômica Ceres, 1995. cap. 24, p. $470-492$.

CAMARGO, L.E.A. Marcadores moleculares no melhoramento para resistência a doenças. In: NASS, L.L., VALOIS, A.C.C., MELO, I.S., VALADARES - INGLIS, M. C. (Eds.). Recursos genéticos \& melhoramento - plantas. Rondonópolis: Fundação MT, 2001. cap. 31, p. 995 - 1010.

CAMILLO, E. Polinização do maracujazeiro. In: RUGGIERO, C. (Ed.). Maracujá. Ribeirão Preto: Legis Summa, 1987. p. 97 - 103.

CANÇADO Jr., F.L.; ESTANISLAU, M.L.L.; PAIVA, B.M. Aspectos econômicos da cultura do maracujá. Informe Agropecuário, v. 21, n. 206, p. 10 - 17, 2000.

CANCINO, O.; HODSON, E. Cultivo de tejidos y micro propagación en "maracuyá" Passiflora edulis var. flavicarpa Degener. Tablero, Revista del Convenio Andrés Bello, v. 18, p. 81 - 83. 1994.

CARDOSO, C.E.L.; SOUZA, J.S.; LIMA, A.A.; COELHO, E.F. Aspectos econômicos. In: LIMA, A. (Ed.). O cultivo do maracujá. Cruz das Almas: Embrapa Mandioca e Fruticultura, 1999. n. 35, p. 109.

CARNEIRO, M.S. Mapas de ligação de maracujá-amarelo (Passiflora edulis Sims f. flavicarpa Deg.). Piracicaba, SP. 2001. 92 p. Tese (Doutorado) - Escola Superior de Agricultura “Luis de Queiroz”, Universidade de São Paulo.

CARNEIRO, M.S.; CAMARGO, L.E.A.; COELHO, A.S.G.; VENCOVSKY, R.; LEITE JÚNIOR, R.P.; STENZEL, N.M.C.; VIERA, M.L.C. RAPD - based genetic linkage maps of yellow passion fruit (Passiflora edulis Sims $f$. flavicarpa Deg.). Genome, v. 45, n. 4, p. $670-678.2002$. 
CERVI, A.C. Passifloraceae: flora do Estado de Goiás. Goiânia: UFG, 1986. p. 1 - 45, (Coleção Rizzo, 7).

CHAN, J.W.Y.F.; GOODWIN, P.H. The molecular genetics of virulence of Xanthomonas campestris. Biotechnology Advances, v. 17, p. 489 - 508, 1999.

CHARNET, R.; FREIRE, C.A.L.; CHARNET, E.M.R.; BONVINO, H. Análise de modelos de regressão linear com aplicações. Campinas: Unicamp, 1999. 356 p.

CHURCHILL, G.A.; DOERGE, R.W. Empirical threshold values for quantitative trait mapping. Genetics, v. 138, p. 963 - 971, 1994.

COELHO, A.S.G. Considerações gerais sobre a análise de QTL. In: PINHEIRO, J.B.; CARNEIRO, I.F. (Eds.). Análise de QTL no melhoramento de plantas. Goiânia: FUNAPE, 2000, p. $01-20$.

CRESTE, S.; TULMANN NETO, A.; FIGUEIRA, A. Detection of single sequence repeat polymorfisms in denaturing polyacrylamide sequencing gels by silver staining. Plant Molecular Biology Reporter, v.19, p.299 - 306, 2001.

CROUZILLAT, D.; LERCETEAU, E.; PETIARD, V.; MORERA, J.; RODRIGUEZ, H.; WALKER, D.; PHILLIPS, W.; RONNING, C.; SCHNELL, R.; OSEI, J.; FRITZ, P. Theobroma cacao L.: a genetic linkage map and quantitative trait loci analysis. Theoretical and Applied Genetics, v. 93, n. 1/2, p. 205 - 214, 1996.

CUNHA, M.A.P. Banco ativo de germoplasma de maracujá. In: REUNIÃO TÉCNICA DE PESQUISA EM MARACUJAZEIRO, 2., Londrina, 1999. Anais, Londrina: IAPAR-SBF, 1999a. p. 72 - 73.

CUNHA, M.A.P. Flor, fruto e semente. In: LIMA, A. (Ed.) O cultivo do maracujá. Cruz das Almas: Embrapa Mandioca e Fruticultura, 1999b. n. 35, p. 26 - 31.

CUNHA, M.A.P. Recursos genéticos e modificações em métodos de seleção para produtividade em maracujá. Revista Brasileira de Fruticultra, v. 18, n. 3, p. 423 423, 1996. 
CURSINO-SANTOS, J.R.; DEFINA, T.P.A.; MARTINEZ-ROSSI, N.M. Os segredos das plantas e de seus patógenos na era molecular. Ribeirão Preto: Sociedade Brasileira de Genética, 2003. v. 1. 41 p.

D’EECKENBRUGGE, G.C. Exploração da diversidade genética das passifloras (compact disc). In: SIMPÓSIO BRASILEIRO SOBRE A CULTURA DO MARACUjAZEIRO, 6., Campos dos Goytacazes, 2003. Palestras. Campos dos Goytacazes: Cluster Informática, 2003.

D’EECKENBRUGGE, G.C.; SEGURA, S.; HODSON DE JARAMILLO, E.; GÓNGORA, G. Les fruits de la passion. In: CHARRIER, A., JACQUOT, M., HAMON, S., NICOLAS, D. (Eds.). L’amélioration des Plantes Tropicales, Repères: Cirad-Orstom, 1997, p. 291 - 312.

DANTAS, J.L.L.; SOARES FILHO, W.S.; OLIVEIRA, J.R.P.; CABRAL, J.R.S.; BARBOSA, L.V.; CUNHA, M.A.P.; RITZINGER, R.; SILVA, S.O. Melhoramento de fruteiras de clima tropical. In: NASS, L.L., VALOIS, A.C.C., MELO, I.S., VALADARES - INGLIS, M. C. (Eds.). Recursos genéticos \& melhoramento plantas. Rondonópolis: Fundação MT, 2001. cap. 17, p. 479 - 547.

DIAS, M.S.C. Principais doenças fúngicas e bacterianas do maracujazeiro. Informe Agropecuário. v. 21, n. 206, p. 34 - 38, 2000.

DIAS, S.C.; TAKATSU, A. Translocação de Xanthomonas campestris pv. passiflorae nos tecidos da hospedeira e sua detecção na semente. Fitopatologia Brasileira, v. 15, n. 2, p.131, 1990.

DÍAZ, C.G.; BASSANEZI, R.B.; GODOY, C.V.; LOPES, D.B.; BERGAMIN FILHO, A. Quantificação do efeito do crestamento bacteriano comum na eficiência fotossintética e na produção do feijoeiro. Fitopatologia Brasileira, v. 26, n. 1, p. 71 $-76,2001$.

DIXON, R.A.; HARRISON, M.J.; LAMB, C.J. Early events in the activation of plant defense responses. Annual Review of Phytopathology, v. 32, p. 479 - 501, 1994. 
DRAPER, N.R.; SMITH, H. Applied regression analysis. 3. ed. New York: John Wiley \& Sons, 1998. 706 p.

DREW, R.A. In vitro culture of adult and juvenile bud explants of Passiflora spp. Plant Cell Tissue and Organ Culture, v. 26, p. 23 - 28, 1991.

EISENHART, C. The assumptions underlying the analysis of variance. Biometrics, v. 3, n. 1 , p. $01-21,1947$.

ESCOBAR, L.A. Biología reproductiva de Passiflora manicata e hibridación con la curuba, Pasiflora mollissima. Actualidades Biológicas, v. 14, p. 111 - 121, 1985.

ESCOBAR, L.A. Experimentos preliminares en la hibridación de especies comestibles de Passiflora. Actualidades Biológicas, v.10, p. 103 - 111, 1981.

FALCONER, D.S.; MACKAY, T.F.C. Introduction to quantitative genetics. 4. ed. New York: Longman Scientific \& Technical. 1996, 464 p.

FALCONER, P.; TITTOTO, K.; PARENTE, T.V.; JUNQUEIRA, N.T.; MANICA, I. Caracterização físico-química de frutos de seis cultivares de maracujá-azedo (Passiflora spp.) produzidos no Distrito Federal. In: SIMPÓSIO BRASILEIRO SOBRE A CUltURA DO MARACUJAZEIRO, 5., Jaboticabal, 1998. Anais, Jaboticabal: FUNEP, 1998. p. $365-367$.

FERNANDES, A.A.; RÊGO, M.M.; BRUCKNER, C.H.; PEREIRA, K.J.C.; RANGEL, A.R.P. Comparação entre técnicas de autofecundação em maracujazeiro Passiflora edulis Sims f. flavicarpa. In: CONGRESSO BRASILEIRO DE FRUTICULTURA, 14., Curitiba, 1996. Anais, Londrina: IAPAR, 1996. p. 334.

FERREIRA, F.R. Germoplasma de Passiflora no Brasil. In: SÂO JOSÉ, A.R. (Ed.). Maracujá: produção e mercado. Vitória da Conquista: DFZ/UESB, 1994. p. 24 26.

FERREIRA, F.R. Recursos genéticos e germoplasma de maracujá (Passiflora spp). In: REUNIÃO TÉCNICA DE PESQUISA EM MARACUJAZEIRO, 3., Viçosa, 2002. Anais, Viçosa:. UFV/SBF, 2002. p. 63 - 66. 
FERREIRA, F.R.; OLIVEIRA, J.C. Germoplasma de Passiflora. In: SÃO JOSÉ, A.R.; FERREIRA, F.R.; VAZ, R.L. (Ed.). A cultura do maracujá no Brasil. Jaboticabal: FUNEP, 1991. p. $61-77$.

FERREIRA, M.E.; GRATTAPAGLIA, D. Introdução ao uso de marcadores moleculares em análise genética. Brasília: EMBRAPA, CENARGEN, 1996. 220 p.

FERREIRA, P.V. Estatística experimental aplicada à agronomia. 3. ed. Maceió: EDUFAL, 2000, 422 p.

FLOR, H.H. The complementary systems in flax and flax rust. Advances in Genetics, v.8, p. $29-54,1956$.

FRANCO, M.M.; TAKATSU, A.; SILVA, J.R. Avaliação de seleções de maracujá quanto à resistência à bacteriose. In: REUNIÃO TÉCNICA DE PESQUISA EM MARACUJAZEIRO, 3., Viçosa, 2002. Anais, Viçosa: UFV/DFT, 2002. p. 132.

GABRIEL, D.W.; ROLFE, B.G. Working models of specific recognition in plantmicrobe interactions. Annual Review of Phytopathology, v. 28, p. 365 - 391, 1990.

GEIGER, H.H.; HEUN, M. Genetics of quantitative resistance to fungal diseases. Annual Review of Phytopathology, v. 27, p. 317 - 341, 1989.

GIACOMETTI, D.C.; FERREIRA, F.R. Situação do germoplasma de espécies frutíferas mais importantes no Brasil. In: CONGRESSO BRASILEIRO FRUTICULTURA, 2., Salvador, 1977. Anais, Cruz das Almas: SBF, 1977. p. 421 - 424.

GOMES, F.P. Curso de estatística experimental. 13. ed. São Paulo: Livraria Nobel, 1990. $430 \mathrm{p}$.

GONÇALVES, E.R.; ROSATO, Y.B. Genotypic characterization of xanthomonad strains isolated from passion fruit plants (Passiflora spp.) and their relatedness to different Xanthomonas species. International Journal of Systematic and Evolutionary Microbiology, v. 50, p. 811 - 821, 2000. 
GRATTAPAGLIA, D. Além dos QTL: desafios para a incorporação de informações de QTL no melhoramento florestal. In: PINHEIRO, J.B.; CARNEIRO, I.F. (Eds.). Análise de QTL no melhoramento de plantas. Goiânia: FUNAPE,.2000. p. 21 36.

GRATTAPAGLIA, D. Marcadores moleculares em espécies florestais: Eucalyptus como modelo. In: NASS, L.L., VALOIS, A.C.C., MELO, I.S., VALADARES INGLIS, M. C. (Eds.). Recursos genéticos \& melhoramento - plantas. Rondonópolis: Fundação MT, 2001. cap. 30, p. 967 - 993.

GRATTAPAGLIA, D.; SEDEROFF, R. Genetic linkage maps of Eucalyptus grandis and Eucalyptus urophylla using a pseudo-testcross: mapping strategy and RAPD markers. Genetics, v. 137, p. 1121 - 1137, 1994.

GRECH, N.M.; RIJKENBERG, F.H.J. Laboratory and field evaluation of the performance of Passiflora caerulea as a rootstock tolerant to certain fungal root pathogens. Journal of Horticultural Science, v. 66, n. 6, p. 725 - 729, 1991.

GRISI JR., C. Método de polinização artificial do maracujazeiro, Passiflora edulis. In: CONGRESSO BRASILEIRO DE FRUTICULTURA, 2., Viçosa, 1973. Anais, Viçosa: SBF, 1973. v. 2, p. 433 - 436.

HALDANE, J.B.S. The combination of linkage values, and the calculation of distance between the loci of linked factors. Journal of Genetics, v. 8, p. 299 - 309, 1919.

HALLAUER, A.R.; MIRANDA FILHO, J.B. Quantitative genetics in maize breeding. Ames: Iowa State University Press, 1988. 468 p.

HAMMOND-KOSACK, K.E.; JONES, J.D.G. Plant disease resistance genes. Annual Review Plant Physiology and Plant Molecular Biology, v. 48, p. 575 - 607, 1997.

HEMMAT, M.; WEEDEN, N.F.; MANGANARIS, A.G.; LAWSON, D.M. Molecular marker linkage map for apple. Journal of Heredity, v. 85, p. 4 - 11, 1994.

HERNÁNDEZ, A.; BERNAL, R. Lista de especies de Passifloraceae de Colombia. Biota Colombiana, v.1, p. 320 - 335, 2000. 
HICKS, C.R. Fundamental concepts in the design of experiments. 2. ed., New York: Rinehart and Winston, 1973. 349 p.

HO, W.F.; SHII, C.T. Incompatibility system in passion fruit (Passiflora edulis Sims). Acta Horticulturae, n. 194, p. 31 - 38, 1986.

INGLEZ DE SOUSA, J.S.; MELETTI, L.M.M. Maracujá: espécies, variedades e cultivo. Piracicaba: FEALQ, 1997. 179 p. (Biblioteca de Ciências Agrárias Luiz de Queiroz, 3).

JADÃO, A.S.; PAVAN, M.A.; KRAUSE-SAKATE, R.; ZERBINI, F.M. Efeitos na fotossíntese e área foliar de cultivares de alface inoculadas mecanicamente com patótipos do Lettuce mosaic virus e Lettuce mottle virus. Fitopatologia Brasileira, v. 29, n. 1, p. $11-15,2004$.

JANSEN, R.C. Controlling the type I and type II errors in mapping quantitative trait loci. Genetics, v. 138, p. 871 - 881, 1994.

JANSEN, R.C. Interval mapping of multiple quantitative trait loci. Genetics, v. 135, p. $205-211,1993$.

JANSEN, R.C.; STAM, P. High resolution of quantitative traits into multipli loci via interval mapping. Genetics, v. 136, p. 1447 - 1455, 1994.

JUNQUEIRA, N.T.V.; ANDRADE, L.M.; SHARMA, R.D; ANJOS, J.R.N.; ANDRADE, L.R.M. Maracujá-doce: Doenças. In: SANTOS FILHO, H.P. E JUNQUEIRA, N.T.V. (Eds.) Maracujá: fitossanidade. Brasília: Embrapa Informação Tecnológica, 2003a. p. 60 - 75.

JUNQUEIRA, N.T.V.; SHARMA R.D.; RITZINGER, C.H.S.P. Manejo da bacteriose e de nematóides em maracujazeiro (compact disc). In: SIMPÓSIO BRASILEIRO SOBRE A CULTURA DO MARACUJAZEIRO, 6., Campos dos Goytacazes, 2003.

Palestras. Campos dos Goytacazes: Cluster Informática, 2003b.

KAO, C.H., ZENG, Z.B., TEASDALE, R.D. Multiple interval mapping for quantitative trait loci. Genetics, v. 152, p. 1203 - 1216, 1999. 
KAVATI, R.; D’EECKENBRUGGE, G.C.: FERREIRA, F.R. Sweet maracuja, a promising newcomer. Fruitrop, n.43, p. 20 - 21. 1998.

KEARSEY, M.J.; FARQUHAR, A.G.L. QTL analysis in plant; where are we now? Heredity, v. 80, p. 137 - 142, 1998.

KEARSEY, M.J.; POONI, H.S. The genetical analysis of quantitative traits. 1 . ed. London: Shapman \& Hall, 1996, 381 p.

KEIM, P.; SCHUPP, J.M.; TRAVIS, S.E.; CLAYTON, K.; ZHU, T.; SHI, L.; FERREIRA, A.; WEBB, D.M. A high-density soybean genetic map based on AFLP markers. Crop Science, v. 37, p. 537 - 543, 1997.

KLEIN, A.L.; FERRAZ, L.C.C.B.; OLIVEIRA, J.C. Comportamento de diferentes maracujazeiros em relação ao nematóide formador de galhas. Pesquisa Agropecuária Brasileira, v. 19, p. 207 - 209, 1984.

KNIGHT JR., R.J. Development of tetraploid hybrid passion fruit clones with potential for the north temperate zone. Hortscience, v. 26, p. 1541 - 1543, 1991.

KNIGHT JR., R.J.; WINTERS, H.F. Pollination and fruit set of yellow passion fruit in southern Florida. Proceedings of the Florida State Horticultural Society, v. 75, p. $412-418,1962$.

KURODA, N. Avaliação do comportamento quanto à resistência de espécies e progênies de maracujazeiro a Xanthomonas campestris pv. passiflorae Pereira. Jaboticabal, 1981. 45 p. Monografia (Graduação) - Faculdade de Ciências Agrárias e Veterinárias, UNESP.

LANDER, E.S.; BOTSTEIN, D. Mapping mendelian factors underlying quantitative traits using RFLP linkage maps. Genetics, v. 121, p. 185 - 199, 1989.

LANDER, E.S.; GREEN, P.; ABRAHAMSON, J.; BARLOW, A.; DALY, M.J.; LINCOLN, E.E.; NEWBURG, L. Mapmaker: an interactive computer package for constructing primary genetic linkage maps of experimental and natural populations.

Genomics, v. 1, p. $174-181,1987$. 
LEITÃO FILHO, H.F.; ARANHA, C. Botânica do maracujazeiro. In: SIMPÓSIO DA CUlTURA DO MARACUJÁ, 1., Campinas, 1971. Anais, Campinas: SBF, 1974. $13 \mathrm{p}$.

LEITE Jr., R.P.; WENDLAND, A.; SHIMAMOTO, R.T.; STENZEL, N.M.C. Avaliação do comportamento de espécies e progênies de Passiflora à bacteriose causada por Xanthomonas sp. pv. passiflorae. IN: REUNIÃO TÉCNICA DE PESQUISA EM MARACUJAZEIRO, 2., Londrina, 1999. Anais, Londrina: Instituto Agronômico do Paraná, 1999. p. 56 - 57.

LEITE JR., R.P. Bacteriose do maracujazeiro e estratégias para seu controle. In: REUNIÃO TÉCNICA DE PESQUISA EM MARACUJAZEIRO, 3., Viçosa, 2002. Anais, Viçosa: UFV/DFT, 2002. p. 97 - 98.

LEITE, R.S.S.; BLISKA, F.M.M.; GARCIA, A.E.B. Aspectos econômicos da produção e mercado. In: Maracujá. Campinas: ITAL, 1994, p.197 - 267.

LEONARDS-SCHIPPERS, C.; GIEFFERS, W.; SCHAÜFFER - PREGL, R.; RITTER, E.; KNAPP, S.J. Quantitative resistance to Phytophthora infestans in potato: a case study of QTL mapping in an allogamous plant species. Genetics, v. 137, p. 67 - 77, 1994.

LEONE, N.R.F.M. Polinização do maracujazeiro (Passiflora edulis f. flavicarpa Deg.) em Araguari-MG. Viçosa, MG, 1990. 76p. Dissertação (Mestrado) - Universidade Federal de Viçosa.

LI, Z.K.; LUO, L.J.; NEI, H.W.; PATERSON, A.H.; ZHAO, X.H.; ZHONG, D.B.; WANG, Y.P.; YU, X.Q.; ZHU, L. TABIEN, R.; STANSEL, J.W.; YING, C.S. A “defeated” rice resistance gene acts as a QTL against a virulent strain of Xanthomonas oryzae pv. oryzae. Molecular Genetics and Genomics, v. 261, n.1, p. $58-63,1999$. 
LIBERATO, J.R. Controle das doenças causadas por fungos, bactérias e nematóides em maracujazeiro. In: ZAMBOLIM, L.; VALE, F.X.R.; MONTEIRO, A.J.A.; COSTA, H. (Eds.). Controle de doenças de plantas: fruteiras. Viçosa: UFV, 2002, v.2, p. $699-826$.

LIBERATO, J.R. Desenvolvimento e avaliação do software QUANT para quantificação de doenças de plantas por análise de imagens. Viçosa, 2004. 126p. Tese (Doutorado) - Universidade Federal de Viçosa.

LIU, B.H. Statistical genomics, New York: CRC, 1998. 610 p.

LOPES, R. Mapas de ligação AFLP e identificação de genes de resistência à Xanthomonas campestris pv. passiflorae em maracujá-amarelo. Piracicaba, SP. 2003. 126 p. Tese (Doutorado) - Escola Superior de Agricultura “Luis de Queiroz", Universidade de São Paulo.

LOPES, R.; LOPES, M.T.G.; FIGUEIRA, A.V.O.; CAMARGO, L.E.A.; FUNGARO, M.H.P.; SAMPAIO, M.S.; VIEIRA, M.L.C. Marcadores moleculares dominantes (RAPD e AFLP). Biotecnologia Ciência \& Desenvolvimento, n. 29, p. 64 - 68, 2003.

LYNCH, M.; WALSH, B. Genetics and analysis of quantitative traits. Sunderland: Sinauer associates, 1998. $980 \mathrm{p}$.

MALAVOLTA JR, V.A. Bacterioses do maracujazeiro. In: SIMPÓSIO BRASILEIRO SOBRE A CULTURA DO MARACUJÁ, 5., Jaboticabal, 1998, Anais, Jaboticabal, 1998. p.217 - 229. 
MALIEPAARD, C.; ALSTON, F.H.; VAN ARKEL, G.; BROWN, L.M.; CHEVREAU, E.; DUNEMANN, F.; EVANS, K.M.; GARDINER, D.; GUILFORD, P.; VAN HEUSDEN, A.W.; JANSE, J.; LAURENS, F.; LYNN, J.R.; MANGANARIS, A.G.; DEN NIJS, A.P.M.; PERIAM, N.; RIKKERINK, E.; ROCHE, P.; RYDER, C.; SANSAVINI, S.; SCHMIDT, H.; TARTARINI, S.; VERHAEGH, J.J.; VRIELINK VAN GINKEL, M. KING, G.J. Aligning male and female linkage maps of apple (Malus pumila Mill.) using multi-allelic markers. Theoretical and Applied Genetics, v. 97, n. 1/2, p. 60 - 73, 1998.

MALIEPAARD, C.; JANSEN, J.; VAN OOIJEN, J.W. Linkage analysis in a full-sib family of an outbreeding plant species: overview and consequences for applications. Genetics Research, v. 70, p. 237 - 250, 1997.

MANDERS, G.; OTONI, W.C.; D'UTRA-VAZ, F.B.; BLACKHALL, N.W.; POWER, J.B.; DAVEY, M.R. Transformation of passionfruit (Passiflora edulis f. flavicarpa Degener) using Agrobacterium tumefaciens. Plant Cell Reports, v. 13, p. 697 702, 1994.

MARTÍN, F.W.; NAKASONE, H.Y. The edible species of Passiflora. Economic Botanic, v. 24, p. 333 - 343, 1970.

MARTINS, M.C.; GUERZONI, R.A.; CÂMARA, G.M.S.; MATTIAZZI, P.; LOURENÇO, S.A.; AMORIM, L. Escala diagramática para a quantificação do complexo de doenças foliares de final de ciclo em soja. Fitopatologia Brasileira, v. 29, n. 2, p. 179 - 184, 2004.

MELETTI, L.M.M. Caracterização agronômica de progênies de maracujazeiro-amarelo (Passiflora edulis Sims. f. flavicarpa Deg.). Piracicaba, SP. 1998. 92 p. Tese (Doutorado) - Escola Superior de Agricultura “Luis de Queiroz”, Universidade de São Paulo. 
MELETTI, L.M.M. Comportamento de híbridos e seleções de maracujazeiro (passifloraceae) (compact disc). In: SIMPÓSIO BRASILEIRO SOBRE A CULtURA DO MARACUJAZEIRO, 6., Campos dos Goytacazes, 2003. Palestras. Campos dos Goytacazes: Cluster Informática, 2003.

MELETTI, L.M.M. Maracujá-Amarelo: cultivares IAC conquistam a preferência nacional l. O Agronômico, v. 53, n. 2, p. 23 - 25, 2001.

MELETTI, L.M.M. Tendências e perspectivas da pesquisa em melhoramento genético do maracujazeiro. In: REUNIÃO TÉCNICA DE PESQUISA EM MARACUJAZEIRO, 3., Viçosa, 2002. Anais, Viçosa: UFV-DFT. 2002. p. 81 - 87.

MELETTI, L.M.M.; BRUCKNER, C.H. Melhoramento genético. In BRUCKNER, C.H.; PICANÇO, M.C. (Eds.) Maracujá: tecnologia de produção, pós-colheita, agroindústria, mercado. Porto Alegre: Cinco Continentes, 2001. p. 345 - 385.

MELETTI, L.M.M.; MAIA, M.L. Maracujá: produção e comercialização. Campinas: Instituto Agronômico, 1999. 62 p. (Boletim Técnico, 181).

MELETTI, L.M.M.; SANTOS, R.R.; MINAMI, K. Melhoramento do maracujazeiroamarelo: Obtenção do ‘Composto IAC-27’. Scientia Agricola, v. 56, n. 3, p. 491 498, 2000.

MELETTI, L.M.M.; SOARES-SCOTT, M.D.; BERNACCI, L.C.; AZEVEDO FILHO, J.A. Caracterização de germoplasma de Passiflora II - $P$. serrato-digitata e $P$. mucronata In: REUNIÃO TÉCNICA DE PESQUISA EM MARACUJAZEIRO, 2., Londrina, 1999. Anais, Londrina: SBF/IAPAR, 1999. p. 85 - 86.

MELETTI, L.M.M.; SOARES-SCOTT, M.D.; BERNACCI, L.C.; MARTINS, F.P. Caracterização de germoplasma de Passiflora - P. amethystina e P. cincinnata. In: SIMPÓSIO LATINOAMERICANO DE RECURSOS GENÉTICOS VEGETAIS, 1., Campinas, 1997. Anais, Campinas, 1997, p.73 - 74. 
MELETTI, L.M.M.; SOARES-SCOTT, M.D.; BERNACCI, L.C.; PINTO-MAGLIO, C.A F; MARTINS, F.P. Caracterização agronômica e seleção de germoplasma de maracujá (Passiflora spp.). In: CONGRESSO BRASILEIRO FRUTICULTURA, 13., Salvador, 1994. Anais, Cruz das Almas: SBF. 1994. v..3, p. 821 - 822.

MELETTI, L.M.M.; SOARES-SCOTT, M.D.; PINTO-MAGLIO, C.A.F; MARTINS, F.P. Caracterização de germoplasma de maracujazeiro (Passiflora sp). Revista Brasileira de Fruticultura, v.14, n.2, p.157 - 162, 1992.

MELO, L.C. Mapeamento de QTLs em feijoeiro, por meio de marcadores RAPD, em diferentes ambientes. Lavras, 2000. 148 p. Tese (Doutorado). Universidade Federal de Lavras.

MICHELMORE, R.W.; MEYERS, B.C. Clusters of resistance genes in plants evolve by divergent selection and birth-and-death process. Genome Research, v. 8, p. 1113 1130, 1998.

MIRANDA, J.F. Reação de variedades de maracujazeiro amarelo (Passiflora edulis Sims f. flavicarpa Deg.) à bacteriose causada por Xanthomonas campestris pv. passiflorae. Piracicaba, 2004. 48p. Dissertação (Mestrado) - Escola Superior de Agricultura “Luiz de Queiroz”, Universidade de São Paulo.

MONTGOMERY, D.C. Design and analysis of experiments. 5. ed. Arizona State University: John Wiley \& Sons, 2001, 684 p.

MURRAY, M.G.; THOMPSON, W.F. Rapid isolation of high molecular weight plant DNA. Nucleic Acids Research, v. 8, p. 1134 - 1137, 1980.

MUSCHNER, V.C.; LORENZ, A.P.; CERVI, A.C.; BONATTO, S.L.; SOUZA-CHIES, T.T.; SALZANO, F.M.; FREITAS, L.B. A first molecular phylogenetic analysis of Passiflora (Passifloraceae). American Journal of Botany, v. 90, p. 1229 - 1238, 2003.

NAKASONE, H.Y.; PAULL, R.E. Tropical Fruits. New York: CAB International, n. 7, 445 p., 1998. 
NAKATANI, A.K. Diversidade genética de Xanthomonas campestris pv. passiflorae e sensibilidade a produtos químicos. Piracicaba, 2001. 61p. Dissertação (Mestrado) Escola Superior de Agricultura “Luiz de Queiroz”, Universidade de São Paulo.

NOGUEIRA FILHO, G.C.; RONCATTO, G.; RUGGIERO, C.; OLIVEIRA, J.C. Avanços em propagação vegetativa do maracujazeiro (compact disc). In: SIMPÓSIO BRASILEIRO SOBRE A CULTURA DO MARACUJAZEIRO, 6., Campos dos Goytacazes, 2003. Palestras. Campos dos Goytacazes: Cluster Informática, 2003.

NOVAES, Q.S.; REZENDE, J.A.M.; KITAJIMA, E.W. Doenças causadas por vírus e fitoplasma em maracujazeiro. Informe Agropecuário, v. 21, n. 206, p. 39 - 51, 2000.

OLIVEIRA, A.M.A. Reprodução e citogenética de espécies de Passiflora. São José do Rio Preto, SP., 1996, 145 p. Tese (Doutorado) - Universidade Estadual Paulista “Júlio de Mesquita”.

OLIVEIRA, J.C. Aspectos do melhoramento do maracujá-amarelo. In: REUNIÃO TÉCNICA DE PESQUISA EM MARACUJAZEIRO NO BRASIL. Cruz das Almas, 1998. Anais, Cruz das Almas: SBF, 1998. p. 38 - 47.

OLIVEIRA, J.C. Melhoramento genético de Passiflora edulis f. flavicarpa Deg visando aumento de produtividade. Jaboticabal, SP. 1980. 133p. Tese (Livre- Docência) Faculdade de Ciências Agrárias e Veterinárias - UNESP.

OLIVEIRA, J.C. Melhoramento genético. In: RUGGIERO, C. (Ed.). Maracujá. Ribeirão Preto: Legis Summa, 1987. p. 218 - 246.

OLIVEIRA, J.C.; FERREIRA, F.R. Melhoramento genético do maracujazeiro. In: SÃO JOSÉ, A.R.; FERREIRA, F.R.; VAZ, R.L. (Eds.). A cultura do maracujá no Brasil. Jaboticabal: FUNEP, 1991. p. 211 - 239.

OLIVEIRA, J.C.; NAKAMURA, K., RUGGIERO, C.; FERREIRA, F.R. Determinações de fonte de resistência em passifloráceas quanto à morte prematura de plantas. In; CONGRESSO BRASILEIRO DE FRUTICULTURA, 8., Araras, 1983. Anais, Araras: SBF, 1983. p. 43. 
OLIVEIRA, J.C.; NAKAMURA, K.; RUGGIERO, C.; FERREIRA, F.R. Determinação de fonte de resistência em Passifloráceas quanto à morte prematura de plantas. In: CONGRESSO BRASILEIRO DE FRUTICUlTURA, 8., Brasília, 1986. Anais, Brasília: EMBRAPA-DDT/CNPq, 1986. p. 403 - 408.

OLIVEIRA, J.C.; PAYÃO DEMATTÊ, M.E.S.; CARNIER, P.E.; PRIOLLI, R.H.G. Hibridação interespecífica entre Passiflora edulis vs. Passiflora caerulea e Passiflora edulis vs. Passiflora coccinea. In: REUNIÃO DA SOCIEDADE BRASILEIRA PARA O PROGRESSO DA CIÊNCIA, 40., São Paulo, 1988. Resumos, São Paulo: SBPC, 1988a. p. 797 - 798.

OLIVEIRA, J.C.; SALOMÃO, T.A.; RUGGIERO,C. Observações sobre o cultivo de Passiflora alata (maracujá guassu). Revista Brasileira de Fruticultura, v. 2, n. 1, p. $59-63,1980$.

OLIVEIRA, J.C.; FERREIRA, F.R.; RUGGIERO, C.; NAKAMURA, K. Caracterização e avaliação de germoplasma de Passiflora edulis. In: CONGRESSO BRASILEIRO FRUTICULTURA, 9., Campinas, 1988. Anais, Campinas: SBF, 1988b. v. 2, p. 591 $-596$.

OLIVEIRA, J.C.; NAKAMURA, K.; MAURO, A.O.; CENTURION, M.A.P.C. Aspectos gerais do melhoramento do maracujazeiro. In: SÃO JOSÉ, A.R. Maracujá, produção e mercado. Vitória da Conquista: DFZ/UESB, 1994. p. 27 37.

OLIVEIRA, J.C.; RUGGIERO, C. Aspectos sobre o melhoramento do maracujazeiroamarelo. In: SIMPÓSIO BRASILEIRO SOBRE A CULTURA DO MARACUJÁ, 5., Jaboticabal, 1998. Anais, Jaboticabal: FUNEP, 1998. p. 291 - 314.

PASSOS, I.R.S. Comportamento in vitro em Vitis spp e em Passiflora nitida H.B.K. Piracicaba, SP. 1999. 112 p. Tese (Doutorado) - Escola Superior de Agricultura “Luis de Queiroz”, Universidade de São Paulo. 
PIO-RIBEIRO, G.; MARIANO, R.L.R. Doenças do maracujazeiro (Passiflora spp.) In: KIMATI, H., AMORIM, L., BERGAMIN FILHO, A., CAMARGO, L.E.A., REZENDE, J.A.M. (Eds.). Manual de fitopatologia: doenças das plantas cultivadas, 3. ed. São Paulo: Agronômica Ceres, 1997. v. 2, p.525 - 537.

PRIOLLI, R.H.G. Avaliação morfológica de híbridos entre Passiflora spp e comportamento em relação ao nematóide formador de galhas Meloidogyne incognita Kofoid, White (1919) Chitwood (1949) raça 1. Jaboticabal, SP., 1991. 88p. Dissertação (Mestrado) - Faculdade de Ciências Agrárias e Veterinárias - UNESP.

PROVINE, W.B. The origins of theoretical population genetics. Chicago: University Chicago Press, Chicago. 1971. 201 p.

PRYOR, T.; ELLIS, J. The genetic complexity of fungal resistance genes in plants. Advances in Plant Pathology, v. 10, p. 281 - 305, 1993.

RAMALHO, M.A.P.; FERREIRA, D.F.; OLIVEIRA, A.C. Experimentação em genética e melhoramento de plantas. Lavras: UFLA, 2000, 326 p.

RÊGO, M.M. Genética, interação pólen-pistilo e expressão de proteínas na autoincompatibilidade do maracujazeiro (Passiflora edulis Sims.). Viçosa, 1997. 66 p. Dissertação (Mestrado) - Universidade Federal de Viçosa.

RÊGO, M.M.; RÊGO, E.; BRUCKNER, C.H.; SILVA, E.A.M.; FINGER, F.L. Pollen tube behavior in yellow passion fruit following compatible and incompatible crosses. Theoretical and Applied Genetics, v. 101, n. 5/6, p. 685 - 689, 2000.

RICE, W.R. Analyzing tables of statistical tests. Evolution, v. 43, n. 1, p. $223-225$. 1989.

RITTER, E.; GEBHARDT, C.; SALAMINI, F. Estimation of recombination frequencies and construction of linkages maps from crosses between heterozygous parents. Genetics, v. 125, p. 645 - 654, 1990. 
RONCATTO, G. Avaliação de cinco espécies de maracujazeiro (Passiflora spp) propagadas por estaquia herbácea. Piracicaba, SP. 2003. 64 p. Tese (Doutorado) Faculdade de Ciências Agrárias e Veterinárias, UNESP.

ROSSI, A D. Comercialização do maracujá. In: RUGGIERO, C. (Ed.) Maracujá: do plantio à colheita. Jaboticabal: FUNEP, 1998. p. 279 - 287.

RUGGIERO, C. Alguns fatores que podem influir na frutificação. In: Ruggiero, C. (Ed.). Maracujá. Ribeirão Preto: Legis Summa, 1987. p. 76 - 85.

RUGGIERO, C.; LAM-SANCHEZ, A.; BANZATTO, D.A. Studies on natural and controlled pollination in yellow passion fruit (Passiflora edulis f. flavicarpa Deg.). Acta Horticulturae, n. 57, p. 121 - 124, 1976.

RUGGIERO, C.; SÃO JOSÉ, A.R.; VOLPE, C.A.; OLIVEIRA, J.C.; DURINGAN, J.F.; BAUMGARTNER, J.G.; SILVA, J.R.; NAKAMURA, K.; FERREIRA, M.E.; KAVATI, R.; PEREIRA, V.P. Maracujá para exportação: aspectos técnicos da produção. Brasília: EMBRAPA - SPI, 1996. 64 p. (FRUPEX. Produções Técnicas, 19).

RUSZKOWSKA, J.; WROBEL, J.T. Tryptophan-derived sulfur-containing phytoalexins: a general overview. Advances in Experimental Medicine and Biology, v. 527, p. 629 - 636, 2003.

SAAL, B.; WRICKE, G.; Clustering of amplified fragment length polymorphism markers in a linkage map of rye. Plant Breeding, v. 121, p. 117 - 123, 2002.

SALOMÃO, L.C.C., PEREIRA, W.E., DUARTE, R.C.C., SIQUEIRA, D.L. Propagação por estaquia dos maracujazeiro doce (Passiflora alata Dryand.) e amarelo (P. edulis f. flavicarpa Deg.). Revista Brasileira de Fruticultura, v. 24, n.1, p. 163 - 167, 2002.

SANTANA, E.N.; LAU, D. Controle do vírus que causa endurescimento-dos-frutos-domaracujazeiro. In: ZAMBOLIM, L., VALE, F.X.R., MONTEIRO, A.J.A., COSTA, H. (Eds.) Controle de doenças de plantas: fruteiras. Viçosa: UFV, 2002. v.2, p. 827 - 836. 
SANTOS FILHO, H.P.; SANTOS, C.C.F.; CORDEIRO, Z.J.M. Doenças causadas por fungos e bactérias. In: LIMA, A. (Ed.). O cultivo do maracujá. Cruz das Almas: Embrapa Mandioca e Fruticultura, 1999. p. 78 - 92. (Série Circular Técnica, 35).

SANTOS, C.C.F.; SANTOS FILHO, H.P. Doenças causadas por bactérias. In: SANTOS FILHO, H.P., JUNQUEIRA, N.T.V. (Ed.) Maracujá: fitossanidade. Brasília: Embrapa Informação Tecnológica, 2003. n.32, p. 22 - 24.

SAS INSTITUTE. SAS OnlineDoc®: version 8. Cary, 1999.

SATTERTHWAITE, F.C. An approximate distribution of estimates of variance components. Biometrics, v. 2, p. $110-114,1946$.

SCARANARI, C.; MELETTI, L.M.M. Programa IAC-EMBRAPA de desenvolvimento, produção, difusão e comercialização de sementes e mudas fiscalizadas-certificadas de maracujazeiro-amarelo. In: REUNIÃO TÉCNICA DE PESQUISA EM MARACUJAZEIRO, 3., Viçosa, 2002. Anais, Viçosa: UFV/DFT, 2002. p. 55 - 56.

SCHOËNIGER, G. La curuba. Técnicas para el mejoramiento de su cultivo. Bogotá: Guadalupe,1986. 255 p.

SEEFELDER, S.; EHRMAIER, H.; SCHWEIZER, G.; SEIGNER, E. Male and female genetic linkage map of hops, Humulus lupulus. Plant breeding, v. 119, p. 249 255, 2000.

SILVA JR., P.F.; TIHOHOD, D.; OLIVEIRA, J.C. de. Avaliação da resistência de maracujazeiros (Passiflora spp.) a uma população de Meloidogyne incognita Raça 1. Nematologia Brasileira, v. 12, p. 103 - 109, 1988.

SILVA-FILHO, M.C.; FALCO, M.C. Plantas transgênicas no melhoramento In: NASS, L.L., VALOIS, A.C.C., MELO, I.S., VALADARES - INGLIS, M. C. (Eds.). Recursos genéticos \& melhoramento - plantas. Rondonópolis: Fundação MT, 2001. cap. 32, p. $1011-1056$.

SNOW, N. New chromosome reports in Passiflora (Passifloraceae). Systematic Botany, v. 18, n. 2, p. 261 - 273, 1993. 
SOUZA, A. P. Biologia molecular aplicada ao melhoramento. In: NASS, L.L., VALOIS, A.C.C., MELO, I.S., VALADARES - INGLIS, M. C. (Eds.). Recursos genéticos \& melhoramento - plantas. Rondonópolis: Fundação MT, 2001. cap. 29, p. $939-965$.

STAHL, E.A.; BISHOP, J.G. Plant-pathogen arms races at the molecular level. Current Opinion in Plant Biology, v.3, p. 299 - 304, 2000.

STASKAWICZ, B.J.; AUSUBEL, F.M.; BAKER, B.J.; ELLIS, J.G.; JONES, J.D. Molecular genetics of plant disease resistance. Science, v. 268, p. 661 - 667, 1995.

STEEL, R.G.D.; TORRIE, J.H.; DICKEY, D.A. Principles and procedures of statistics: a biometrical approach. 3. ed. New York: McGraw-Hill, 1997. 666 p.

STEFFENSON, B.J.; HAYES, P.M.; KLEINHOFS, A. Genetics of seedling and adult plant resistance to net blotch (Pyrenophora teres f. teres) and spot blotch (Cochliobulos sativus) in barley. Theoretical and Applied Genetics, v. 92, n. 5, p. $552-558,1996$.

STENZEL, N.M.C.; SERA, T. Melhoramento genético de maracujá-amarelo (Passiflora edulis f. flavicarpa) no Paraná. In: REUNIÃO TÉCNICA DE PESQUISA EM MARACUJAZEIRO, 2., Londrina, 1999. Anais, Londrina: IAPAR-SBF, 1999, p. 81.

STUBER, C.W.; LINCOLN, S.E.; WOLFF, D.W.; HELENTJARIS, T.; LANDER, E.S. Identification of genetic factors contributing to heterosis in a hybrid from two elite maize inbred lines using molecular markers. Genetics, v. 132, p. 823 - 839, 1992.

SUASSUNA, T.M.F.; BRUCKNER, C.H.; CARVALHO, C.R.; BORÉM, A. Selfincompatibility in passionfruit: evidence of gametophytic-sporophytic control. Theoretical and Applied Genetics, v. 106, n. 2, p. 298 - 302; 2003.

TANKSLEY, S.D. Mapping polygenes. Annual Reviews of Genetic, v.27, p. 205 233, 1993. 
TEIXEIRA, C.G. Cultura. In: São Paulo (Estado). Instituto de Tecnologia de Alimentos. Maracujá: cultura, matéria prima, processamento e aspectos econômicos. Campinas: ITAL. 1994, p. 3 - 142.

TSAY, H.S.; HSU, J.Y.; YANG, T.P.; YANG, C.R. Anther culture of passion fruit (Passiflora edulis). Journal of Agricultural Research of China, v. 33, n. 2, p. 126 $-131,1984$.

URASHIMA, A S. Aspectos fenológicos do maracujazeiro-amarelo (Passiflora edulis f. flavicarpa). Botucatu, SP., 198583 p. Dissertação (Mestrado). Faculdade de Ciências Agrárias e Veterinárias - UNESP.

VALE, F.X.R.; PARLEVLIET, J.E.; ZAMBOLIM, L. Concepts in plant disease resistance. Fitopatologia Brasileira, v.26, p. 577 - 589, 2001.

VALLINI, P.C.; RUGGIERO, C.; LAM-SANCHES, A.; FERREIRA, F.R. Studies on the flowering period of yellow passion fruit Passiflora edulis f. flavicarpa Deg. in the region of Jaboticabal, São Paulo. Acta Horticulturae, v. 57, p. 233 - 236, 1976.

VAN DER VOORT, J.R.; VAN DER VOSSEN, E.; BAKKER, E.; OVERMARS, H.; VAN ZANDVOORT, P.; HUTTEN, R.; LANKHORST, R.K.; BAKKER, J. Two additive QTLs conferring broad-spectrum resistance in potato to Globodera pallida are localized on gene clusters. Theoretical and Applied Genetics, v. 101, n. 7, p. $1122-1130,2000$.

VAN ECK, H.J.; VAN DER VOORT, J.R.; DRAAISTRA, J.R.; VAN ZANDVOORT, P.; VAN ENCKEVORT, E.; SEGERS, B.; PELEMAN, J.; JACOBSEN, E.; HELDER, J.; BAKKER, J. The inheritance of chromosomal localization of AFLP markers in a non-inbred potato offspring. Molecular Breeding, v. 1, p. $397-410$, 1995.

VAN OOIJEN, J.W. LOD significance thresholds for QTL analysis in experimental populations of diploid species. Heredity, v. 83, p. 613 - 624, 1999. 
VAN OOIJEN, J.W.; BOER, M.P.; JANSEN, R.C.; MALIEPAARD, C. MapQTL ${ }^{\circledR}$ version 4.0: Software for the calculation of QTL positions on genetic maps. Wageningen: Plant Research International. 2000.

VAN OOIJEN, J.W.; VOORRIPS, R.E. JoinMap ${ }^{\circledR}$ 3, Software for the calculations of genetic linkage maps. Wageningen: Plant Research International. 2001.

VANDERPLANK, J. Passion flowers and passion fruit. London: Cassel, 1991. 176 p.

VANDERPLANK, J.E. Plant diseases: epidemics and control. New York: Academic Press, 1963. 349 p.

VARAJÃO, A.J.C.; RUGGIERO, C.; BANZATTO, D.A. Variações do fruto do maracujazeiro-amarelo (Passiflora edulis f. flavicarpa Deg.) In: CONGRESSO BRASILEIRO DE FRUTICULTURA, 2., Viçosa, 1973. Anais, Viçosa, 1973, p. $441-447$.

VASCONCELLOS, M.A.S; DUARTE FILHO, J. Ecofisiologia do maracujazeiro Informe Agropecuário. v. 21, n. 206, p. 25 - 28, 2000.

VIEIRA, M.L.C. Genética e biotecnologia do maracujazeiro (compact disc). In: SIMPÓSIO BRASILEIRO SOBRE A CULTURA DO MARACUJAZEIRO, 6., Campos dos Goytacazes, 2003. Palestras. Campos dos Goytacazes: Cluster Informática, 2003.

VIEIRA, M.L.C.; DORNELAS, M.C. Regeneration of plants from protoplasts of Passiflora species (Passion fruit). In: BAJAJ, Y.P.S. (Ed.). Biotechnology in agriculture and forestry. Plant protoplasts and genetic engineering VII. Berlin: Springer Verlag, 1996, v.38, p. 108 - 119.

VOS, P.; HOGERS, R.; BLEEKER, M.; REIJANS, M.; VAN DE LEE, T.; HORNES, M.; FRIJTERS, A.; POT, J.; PELEMAN, J.; KUIPER, M.; ZABEAU, M. AFLP: a new technique for DNA fingerprinting. Nucleic Acids Research, v. 23, n. 21, p. $4407-4414,1995$. 
VUYLSTEKE, M.; MANK, R.; ANTONISE, R.; BASTIAANS, E.; SENIOR, M.L.; STUBER, C.W.; MELCHINGER, A.E.; LÜBBERSTEDT, T.; XIA, X.C.; STAM, P.; ZABEAU, M.; KUIPER, M. Two high-density AFLP ${ }^{\circledR}$ linkage maps of Zea mays L.: analysis of distribution of AFLP markers. Theoretical and Applied Genetics, v. 99, n. 6, p. $921-935,1999$.

WANG, G.; MACKILL, D.L.; BONMAN, M.; McCOUCH, S.R.; CHAMPOUX, M.C.; NELSON, R. RFLP mapping of genes conferring complete and partial resistance to blast in a durably resistance rice cultivar. Genetics, v. 136, p. 1421 - 1434, 1994.

WELLER, J.L. Maximum likelihood techniques for the mapping and analysis of quantitative trait loci with the aid of genetic markers. Biometrics, v. 42, p. 627 640, 1986.

WENDLAND, A. Avaliação de espécies de maracujazeiro (Passiflora spp.) à bacteriose e caracterização de Xanthomonas sp. pv. passiflorae. Londrina, 1997. 87p. Monografia (Graduação) - Universidade Estadual de Londrina.

WU, R.; MA, C-X. Simultaneous maximum likelihood estimation of linkage phases in outcrossing species. Theoretical Population Biology, v.61, p. 349 - 363, 2002.

YAMASHIRO, T.; LANDGRAF, J.H. Maracujá-açu (Passiflora alata Ait), portaenxerto resistente à fusariose do maracujazeiro (Passiflora edulis f. flavicarpa Deg.) In: CONGRESSO BRASILEIRO DE FRUTICUlTURA, 4., Pelotas, 1979. Anais, Pelotas, 1979. p. $918-921$.

YIN, T.; HUANG, M.; WANG, M.; ZHU, L.-H.; ZENG, Z.-B.; WU, R. Preliminary interspecific genetic maps of the Populus genome constructed from RAPD markers. Genome, v. 44, p. 602 - 609, 2001.

YIN, X.; CHASALOW, S.D.; STAM, P.; KROPFF, M.J.; DOURLEIJN, C.J.; BOS, I.; BINDRABAN, P.S. Use of component analysis in QTL mapping of complex crop traits: a case study on yield in barley. Plant Breeding, v. 121, p. 314 - 319, 2002. 
YORINORI, J.T.; KIIHL, R.A.S. Melhoramento de plantas visando resistência a doenças. In: NASS, L.L., VALOIS, A.C.C., MELO, I.S., VALADARES - INGLIS, M. C. (Eds.). Recursos genéticos \& melhoramento - plantas. Rondonópolis: Fundação MT, 2001. cap. 23, p. 715 - 735.

YOUNG, N. QTL mapping and quantitative disease resistance in plants. Annual Review of Phytopathology, v. 34, p. 479 - 501, 1996.

YOUNG, W.P.; SCHUPP, J.M.; KEIM, P. DNA methylation and AFLP marker distribution in the soybean genome. Theoretical and Applied Genetics, v. 99, n.5, p. $785-792,1999$.

ZABEAU, M. Selective restriction fragment amplification: a general method for DNA fingerprinting. European Patent Application n. 0534858 A1, 1993.

ZENG, Z.B. Precision mapping of quantitative trait loci. Genetics, v. 136, p. 1457 1466, 1994. 
APÊNDICE 1 


\title{
AFLP LINKAGE ANALYSIS AND MAPPING OF RESISTANCE GENES TO Xanthomonas axonopodis pv. passiflorae IN YELLOW PASSION FRUIT
}

Ricardo Lopes, Maria Teresa Gomes Lopes, Monalisa Sampaio Carneiro, Frederico de Pina Matta, Luis Eduardo Aranha Camargo and Maria Lucia Carneiro Vieira.

\begin{abstract}
The cultivated passion fruit (Passiflora edulis f. flavicarpa) is a crosspollinated species native to South America. In the current study, a segregating $\mathrm{F}_{1}$ population derived from a single cross between the clones 'IAPAR-06' and 'IAPAR123' was used to construct AFLP-based linkage maps and to map resistance genes to bacterial spot caused by Xanthomonas axonopodis pv. passiflorae. Linkage analysis was performed by the two-way pseudo-testcross mapping method using markers that segregated in a 1:1 ratio. The 'IAPAR-06' linkage map was constructed using 115 markers, 112 of which were allocated to 9 linkage groups (LG) covering 790.2 cM. The map of 'IAPAR-123' was constructed using 140 markers, 138 of which were allocated to 9 LG covering $488.9 \mathrm{cM}$. In both maps, clusters of markers were detected, indicating that the AFLP markers were not distributed at random. Bacterial resistance was assessed by measuring the diseased leaf area after wound inoculating the leaves of $F_{1}$ plants. Quantitative resistance loci (QRL) mapping was carried out by composite interval mapping and one QRL was detected, which explained 15.8\% of the total phenotypic variation. The possibility of considering these data for marker-assisted selection in passion fruit breeding programs is discussed.
\end{abstract}

\section{INTRODUCTION}

The genus Passiflorae comprises 22 subgenera and 465 species. It is native to South America and its main distribution center is located in the central-northern region of Brazil, where approximately 200 species are found. Many Passiflora are cultivated as ornamentals, and for their edible fruits or medicinal properties (Meletti and Bruckner, 2001). Among the cultivated species, $P$. edulis is the most important, especially $P$. edulis f. flavicarpa, the yellow passion fruit $(2 n=18)$, which has a self-incompatibility system. 
It is a naturally allogamous plant, insect-pollinated. Therefore, there is a high level of heterozygosity in each plant, and the passion fruit genome is adapted to this state.

Although the commercial exploitation of the species is rather recent, concentrated passion fruit juice comes second on the list of fruit juices exported by Brazil, especially to the European Community (Cançado Jr. et al., 2000). However, the lack of varieties that combine high productivity, quality and resistance to diseases has hindered efforts to increase the productivity of Brazilian orchards. The bacterial leaf spot caused by Xanthomonas axonopodis pv. passiflorae is one of two major limiting diseases of the passion fruit orchards. The pathogen attacks leaves and fruits, causing severe damage (Pio-Ribeiro \& Mariano, 1997), and chemical control led to inconsistent results. Therefore, the development of resistant varieties is the most promising solution for controlling the disease.

With the advent of molecular markers based on the polymerase chain reaction (PCR) - namely RAPD (Williams et al., 1990) and AFLP (Vos et al., 1995) - the construction of high-density genetic maps became possible for almost all plant species. These maps provided the basis for quantitative resistance loci (QRL) mapping and opened up new perspectives for marker-assisted selection (MAS). This study was undertaken in light of the possibilities of using molecular markers to assist the selection of yellow passion fruit genotypes resistant to bacterial spot. Here we report on the construction of AFLP linkage maps and the mapping of QRL for X. axonopodis pv. passiflorae.

\section{MATERIAL AND METHODS}

\section{Mapping population}

The passion fruit F1 mapping population was obtained by Carneiro et al. (2002). It derives from a cross between two non-inbred clones i.e. 'IAPAR-06', which was introduced from Morocco and 'IAPAR-123' that is a selection from the Brazilian 'Maguary' commercial population. Both clones belong to the Passiflora collection of the Instituto Agronômico do Paraná (IAPAR, Londrina, Brazil). This full-sib mating 
produced the $117 \mathrm{~F}_{1}$ individuals used in the present study, which were kept in a greenhouse and propagated by cuttings to be used for DNA extractions and disease resistance evaluations.

\section{AFLP protocol}

Genomic DNA was isolated from young leaves according to Vieira et al. (1997). The AFLP method was implemented as described in Vos et al. (1995), with modifications. DNA digestion. Two enzyme combinations were used for genomic DNA digestion: EcoRI/MseI and PstI/MseI. EcoRI/MseI digestion was carried out using 300 ng of genomic DNA, 5.0 $\mu \mathrm{L}$ "One Phor All" buffer 10X (OPA; Amersham, Buckinghamshire, England), $0.5 \mu \mathrm{L}$ BSA (Bovine Serum Albumin) (10 $\mu \mathrm{g} / \mu \mathrm{L}), 0.5 \mu \mathrm{L}$ MseI enzyme (10 units/ $\mu \mathrm{L}$, New England Biolabs, Beverly, USA) and 0.5 $\mu \mathrm{L}$ EcoRI enzyme (10 units/ $\mu \mathrm{L}$; Gibco, New York, USA) The above reaction volumes are for a 50 $\mu \mathrm{L}$ reaction. The same concentrations were used for DNA digestion with PstI/MseI enzyme, except that React1 10X (Gibco) buffer was used instead of OPA, and PstI enzyme (10 units/ $\mu \mathrm{L}$; Gibco) instead of EcoRI. Digestion reactions were incubated at $37^{\circ} \mathrm{C}$ for $3 \mathrm{~h}$ and then deactivated at $70^{\circ} \mathrm{C}$ for $15 \mathrm{~min}$.

Adapter ligation. Ligation reactions were carried out using $2.0 \mu \mathrm{L}$ T4 DNA ligase buffer 5X (Invitrogen, Carlsbad, USA), $1.0 \mu \mathrm{L}$ of adapter for rare-cutting enzyme (EcoRI or PstI), $1.0 \mu \mathrm{L}$ of adapter for frequent-cutting enzyme (MseI), 1.0 $\mu \mathrm{L}$ T4 DNA ligase enzyme ( 1 unit/ $\mu \mathrm{L}$, Invitrogen), $5.0 \mu \mathrm{L}$ sterile distilled water and $40 \mu \mathrm{L}$ of digestion solution. Ligation reactions were incubated at $20^{\circ} \mathrm{C}$ for $3 \mathrm{~h}$.

Pre-amplification of primary template DNA. Pre-selective PCR was performed for carrying a single 3'- selective nucleotide. Three different primer combinations were used: $\mathrm{E}+\mathrm{A} / \mathrm{M}+\mathrm{C}, \mathrm{E}+\mathrm{T} / \mathrm{M}+\mathrm{G}$ and $\mathrm{P}+\mathrm{A} / \mathrm{M}+\mathrm{C}$. The reaction mixture was composed of 3.0 $\mu \mathrm{L}$ of DNA sample, $0.5 \mu \mathrm{L}$ of primers that match the adapter sequence for rare-cutting enzyme $(\mathrm{E}+\mathrm{A}, \mathrm{E}+\mathrm{C}$ or $\mathrm{P}+\mathrm{A})(50 \mathrm{ng} / \mu \mathrm{L}), 0.5 \mu \mathrm{L}$ of primers that match the adapter sequence for frequent-cutting enzyme $(\mathrm{M}+\mathrm{C}$ or $\mathrm{M}+\mathrm{G})(50 \mathrm{ng} / \mu \mathrm{L}), 4.0 \mathrm{~mL}$ dNTP $2.5 \mu \mathrm{M}$ 
(Gibco), $2.0 \mu \mathrm{L}$ "Mg Free Buffer" 10X (Promega, Madison, USA), $1.2 \mu \mathrm{L} \mathrm{MgCl}_{2} 25$ mM, 0.6 $\mu \mathrm{L}$ Taq DNA polimerase (5.0 units/ $\mu \mathrm{L}$; Promega) and $8.2 \mu \mathrm{L}$ sterile distilled water. The thermocycler was programmed as follows: preliminary denaturation (2 min, $94^{\circ} \mathrm{C}$ ), followed by 26 cycles composed of denaturation $\left(1 \mathrm{~min}, 94^{\circ} \mathrm{C}\right)$, annealing $(1 \mathrm{~min}$, $56^{\circ} \mathrm{C}$ ) and extension $\left(1 \mathrm{~min}, 72^{\circ} \mathrm{C}\right)$, and a final extension step (5 min, $72^{\circ} \mathrm{C}$ ). Preamplification products were diluted in $80 \mu \mathrm{L}$ sterile distilled water.

Selective restriction-derived fragments amplification. Selective PCR was conducted using $1.5 \mu \mathrm{L}$ of preamplification products diluted, $0.5 \mu \mathrm{L}$ primer for rarecutting enzyme $(\mathrm{E}+\mathrm{NNN}$ or $\mathrm{P}+\mathrm{NNN})(50 \mathrm{ng} / \mu \mathrm{L}), 0.6 \mu \mathrm{L}$ primer for frequent-cutting enzyme (M+NNN) (50 ng/ $\mu \mathrm{L}), 1.6 \mathrm{~mL}$ dNTP $2.5 \mathrm{mM}$ (Gibco), $2.0 \mu \mathrm{L}$ Taq polimerase buffer 10X (Promega), $1.2 \mu \mathrm{L} \mathrm{MgCl}_{2} 25 \mathrm{mM}, 0.32 \mu \mathrm{L}$ Taq DNA polimerase (5 units/ $\mu \mathrm{L}$, Promega) and $12.28 \mu \mathrm{L}$ sterile distilled water. PCR amplifications were conducted with preliminary denaturation $\left(2 \mathrm{~min}, 94^{\circ} \mathrm{C}\right)$, followed by 12 cycles of $30 \mathrm{sec}$ denaturation at $94^{\circ} \mathrm{C}, 30 \mathrm{sec}$ annealing at $65^{\circ} \mathrm{C}(-0.7$ sec per cycle) and 60 sec extension at $72^{\circ} \mathrm{C}$. The annealing temperature $\left(65^{\circ} \mathrm{C}\right)$ used for the first cycle was reduced to $0.7^{\circ} \mathrm{C}$ for each of the following 12 cycles; for the remaining 23 cycles, the temperature reached $56^{\circ} \mathrm{C}$, followed by a final hold during $2 \mathrm{~min}$ at $72^{\circ} \mathrm{C}$. A total of 174 primer combinations were evaluated in selective amplification corresponding to $90 \mathrm{E}+\mathrm{ANN} / \mathrm{M}+\mathrm{CNN}, 28$ $\mathrm{E}+\mathrm{TNN} / \mathrm{M}+\mathrm{GNN}$, and $56 \mathrm{P}+\mathrm{ANN} / \mathrm{M}+\mathrm{CNN}$ combinations. A preliminary evaluation of primer combinations was screened against the two parents and two $F_{1}$ individuals. Amongst the 174 primer combinations analyzed, 34 were used for mapping (20 $\mathrm{E}+\mathrm{ANN} / \mathrm{M}+\mathrm{CNN}, 4 \mathrm{E}+\mathrm{TNN} / \mathrm{M}+\mathrm{GNN}$, and $10 \mathrm{P}+\mathrm{ANN} / \mathrm{M}+\mathrm{CNN}$ combinations).

\section{Separation of AFLP fragments and revelation}

Reaction products $(20 \mu \mathrm{L})$ were mixed with a $10 \mu \mathrm{L}$ solution of formamide dye (98\% formamide, 10 mM EDTA pH8.0, bromophenol blue $0.002 \%$, xylene cyanol $0.002 \%$ ). The mixture was denatured at $95{ }^{\circ} \mathrm{C}$ for $5 \mathrm{~min}$, and $14 \mu \mathrm{L}$ were loaded on the wells. Previously-warmed 1 x TBE buffer (100 mM Tris, $100 \mathrm{mM}$ boric acid, $2 \mathrm{mM}$ EDTA) was used to pre-run 0.5 mm-thick $6 \%$ polyacrylamide denaturing gels (6\% 
acrylamide/bisacrylamide (19:1) and 7.5 M urea gel) in BioRad (Hercules, USA) $38 \mathrm{x}$ $50 \mathrm{~cm}$-sequencing apparatus for $1 \mathrm{~h}$ at $80 \mathrm{~W}$. Gels run for $4 \mathrm{~h}: 30 \mathrm{~min}$ at $80 \mathrm{~W}$. The DNA was visualized by silver staining as described in details by Creste et al. (2001).

\section{Scoring of data and marker nomenclature}

Due to the mode of reproduction of $P$. edulis flavicarpa, both parents are expected to display a high level of heterozygosity. Consequently, the pseudo-testcross strategy was used for construct the linkage maps. Two sets of informative locus were detected and two maps, one for each parent, were constructed. Only markers that segregated in a 1:1 (presence: absence) ratio were considered for the analysis. For genotyping purposes plants with the presence or absence of a given AFLP marker-locus were scored as $\mathrm{H}$ (heterozygote) and A (homozygote), respectively, thus allowing Mapmaker to compute LOD or similar scores, and to correctly identify linkage between markers in both coupling and repulsion phases. Segregation ratios were tested by $\chi^{2}$ analyses using the False Discovery Rate (FDR) criterion (Benjamin \& Hocheberg, 1995) to determine the significance level. AFLP loci nomenclature consisted of two letters and five numbers. The letters represent the enzymes used in the digesting reaction $(E c o R I=$ $\mathrm{E}, \mathrm{Mse} \mathrm{I}=\mathrm{M}$, and PstI $=\mathrm{P}$ ) and the first two numbers indicate the combination of primers (Table 1). The last three numbers correspond to the molecular size of the AFLP fragment.

\section{Disease evaluation}

A total of 117 individuals F1 were screened for resistance to $X$. axonopodis pv. passiflorae using a randomized complete block design consisting of three blocks placed in a greenhouse. Plots consisted of one plant from which three leaves were inoculated. Inoculations were done by cutting off a $3 \mathrm{~cm}$-strip from the tip of fully expanded leaves using a scissors that was previously immersed in a bacterial suspension adjusted to a concentration of $108 \mathrm{CFU} / \mathrm{ml}$. Inoculums were raised by growing the strain $18 \mathrm{~b}$ 
(Nakatani, 2001) on nutrient agar medium (10g/L peptone, 3g/L meat extract and $20 \mathrm{~g} / \mathrm{L}$ agar) at $28^{\circ} \mathrm{C}$ for $48 \mathrm{~h}$. Plates were flooded with sterile water, and a bacterial suspension was obtained by scraping the surface of the plates. The concentration of the bacterial suspension was adjusted to an optical density $(600 \mathrm{~mm})$ of 0.3 using a spectrophotometer. The diseased leaf area $\left(\mathrm{cm}^{2}\right)$ was evaluated 20 days after inoculation by tracing the edges of individual lesions on an acetate transparency sheet and measuring those areas with a Li-3100 leaf area meter (Li-cor, Nebraska, EUA). The mean diseased leaf area (DLA) of the three leaves and three replicates was used for QRL analysis. Data were grouped in classes which number was based on the normality distribution as in Scott (1979), and described graphically.

\section{Linkage and data analyses}

Segregating data were analyzed as in the double pseudo-testcross design (Grattapaglia and Sederoff, 1994) using Mapmaker PC version 3.0 (Lander et al., 1987). To allow the detection of AFLP marker linkage at the repulsion phase, the data set was duplicated and re-coded. The original data codes were named "a" and the re-coded as "r". Thus, if two linked markers have the same code (a-a or r-r) they are linked in coupling phase. Otherwise, they are linked in the repulsion phase. A minimum LOD score of 4.0 and a maximum recombination fraction of 0.30 were used as threshold for accepting linkage in 'IAPAR-123', but a minimum LOD score of 3.0 and a maximum recombination fraction of 0.50 were used as threshold for accepting linkage in 'IAPAR06 .

For each linkage group, marker order was defined using the "order" command with LOD score 3.0. The "ripple" command was used to confirm such orders. Other markers were then added using a LOD score threshold 2.0. Fragments that could not be ordered with this threshold value were referred to as accessory markers and were positioned in the map using the "place" command. These loci are listed to the right of the framework, close to their most likely positions (Figure 1 and 2). Haldane’s mapping function was used to convert recombination frequencies to map distances in 
centimorgans (cM). Mapmaker error-detection functions were employed to check potential genotyping errors on the framework map.

Prior to QRL mapping, the normality of the phenotypic data was examined using the Lilliefors' test (Lilliefors, 1967). Mean DLA of the F1 plants and parental clones were subjected to ANOVA and compared. QRL mapping was performed by composite interval mapping (Zeng, 1994). To obtain the cofactors, multiple linear regression analysis was achieved by using markers as independent variables and phenotypic characteristics as dependent variables as in Edwards et al. (1987). Marker selection from regression model was accomplished by the stepwise procedure (Draper and Smith, 1981). The level of significance 0.05 was used to add and keep markers in the model. Composite interval mapping analysis was performed separately for the 'IAPAR 06' and 'IAPAR 123' linkage maps. The stepwise procedure was used for selecting regression variables, and the level of significance 0.05 was used to add and keep makers in the model. Threshold levels to declare significant QRL were determined by performing 1,000 data permutations, which kept the chromosome-wise Type-I error rate at 0.05 (Churchill and Doerge, 1994). QRL analysis was performed using QTL Cartographer (version 2.0 for Windows).

\section{RESULTS}

One hundred and seventy four primer combinations were used to generate 10,200 AFLP markers, which correspond to an average of 60 bands per primer combination. Of these, 1,355 ( 13\%) loci were polymorphic, about 8 per primer combination. The 90 primer combinations $\mathrm{E}+\mathrm{ANN} / \mathrm{M}+\mathrm{CNN}$ revealed 4,800 bands from which 672 were informative loci $(\sim 14 \%)$. The number of amplified fragments per combination ranged from 23 to 113 (as average, 54 fragments per combination). The 28 combinations $\mathrm{E}+\mathrm{TNN} / \mathrm{M}+\mathrm{GNN}$ revealed 1,965 bands from which 236 were informative ( 12\%). The number of amplified fragments per combination ranged from 52 to 92 (as average, 70 fragments per combination). The 56 primer combinations $\mathrm{P}+\mathrm{ANN} / \mathrm{M}+\mathrm{CNN}$ revealed about 3,400 fragments, 447 of them being polymorphic ( 13\%). The number of 
amplified fragments per combination ranged from 29 to 103 (as average, 61 fragments per combination).

The number of amplified loci matches the number of individually separated fragments, whose actual number was above the estimate. Many of the amplified fragments were not considered because at the top of the AFLP gel fragments larger than 800 bp overlapped. Nevertheless, about $10 \%$ of the fragments included in our analyses were $>800$ bp.

From the total of 174 primer combinations screened by selective amplification from parental DNA and two F1 plants, 34 primers were used for constructing the linkage maps, being $20 \mathrm{E}+\mathrm{ANN} / \mathrm{M}+\mathrm{CNN}, 4 \mathrm{E}+\mathrm{TNN} / \mathrm{M}+\mathrm{GNN}$ and $10 \mathrm{P}+\mathrm{ANN} / \mathrm{M}+\mathrm{CNN}$ (Table 1). The choice of combinations was based on the number of polymorphic loci per gel and band distinctness. A total of 419 polymorphic loci was obtained, being 327 EcoRI/MseI ( 14 loci per combination) and 92 PstI/MseI ( 9 loci per combination). The number of polymorphic loci (1:1 and 3:1) ranged from 7 to 24 when the enzyme combination was EcoRI/MseI, and from 3 to 15 when PstI/MseI was used. Of the total number of amplified loci, 77 and 88\% derived from EcoRI/MseI and PstI/MseI combinations, respectively. Molecular weights varied from 50 to $500 \mathrm{bp}$.

\section{Phenotypic data}

Large amplitude for mean DLA was observed in the mapping population that ranged from 1.14 to $25.48 \mathrm{~cm}^{2}$, with an average of $12.43 \mathrm{~cm}^{2}$. Phenotypes were distributed in eight classes (Figure 3). According to Lilliefors' test $(\mathrm{P}<0.05)$, the phenotypic data and errors associated with them did not display a normal distribution. Despite statistical rejection, the observed distribution was close to the normality. The analysis of variance was performed using data transformed to $(\sqrt{x})$, and the means were submitted to Tukey test (data not shown). The coefficient of variation dropped from $27.36 \%$ to $13.16 \%$ after data transformation. Regarding transgressive segregation, eight individuals from the mapping population showed mean DLA larger than $19.47 \mathrm{~cm}^{2}$ 
('IAPAR-06'), and only one lower than $3.89 \mathrm{~cm}^{2}$ ('IAPAR-123'), though not statistically different.

\section{Linkage maps}

Of the 419 AFLP polymorphic loci detected, 303 segregated in a 1:1 ratio (mono-parental loci) and 116 in a 3:1 ratio (bi-parental loci), of which 144 (47.5\%) came from 'IAPAR 06' and 159 (52.5\%) from 'IAPAR 123' (Table 1). However, polymorphic markers existing in less than 100 individuals or that could not be scored on gels were excluded from the linkage analyses. Thus, for the construction of the maps, 263 mono-parental loci were used, of which 118 came from 'IAPAR-06' and 145 from 'IAPAR-123'. These loci were submitted to $\chi^{2}$ analysis, and eight of them (3\%) exhibited segregation distortion, according to FRD criteria. The distortion level was quite similar in both parents. Loci that show distortion to mendelian proportions were not used because they affect the statistical tests utilized to detect linkage and can generate false positives (Liu, 1998). Thus, 115 and 140 loci were used to generate the 'IAPAR-06' and 'IAPAR-123' maps, respectively.

The 'IAPAR-06' map: From a total of 115 markers, 112 established the map (Figure 1). Approximately $64.3 \%$ of them (72 loci) were allocated on the framework map with LOD score $>2.0$, covering $790.2 \mathrm{cM}$ (Table 2). Forty markers (35.7\%) were classified as accessory markers and three regarded as unlinked markers (2.6\%). The linkage groups consisted of 3 to 36 markers, and the number of markers ordered per linkage group ranged between 3 and 16. The length of the groups ranged from 11.9 to 208.9 cM. Two markers co-segregated (1.8\%).

The 'IAPAR-123' map: From a total of 140 markers, 138 established the map (Figure 2), 57 of them (41.3\%) were allocated on the framework map with LOD score > 2.0, covering $488.9 \mathrm{cM}$ (Table 2). The 81 remaining markers (58.7\%) were classified as accessory markers and two regarded as unlinked markers (1.4\%). Linkage groups consisted of 8 to 23 markers, and the number of markers ordered by linkage group 
ranged between 3 and 11 . The length of the groups ranged from 8.4 to $140.4 \mathrm{cM}$. Twelve markers co-segregated (8.7\%).

\section{Mapping quantitative resistance loci}

To choose the cofactors by multiple linear regression using the stepwise procedure, the loci of both parental were treated together. The final regression model was composed of two markers of the 'IAPAR-123', which showed the largest level of resistance in the phenotypic evaluation. The markers PM023558r (p-value=0.0001) and EM2378a (p-value=0.0372) remained in the final model.

The signal of the partial regression coefficient, in the positive case, indicated that the PM023558r (3.742) marker is linked at the repulsion phase with a resistance allele, meaning that its presence is associated with an increasing in DLA. This marker was attributed to the linkage group 2 in the 'IAPAR-123'map as an accessory marker, and is located at $8.1 \mathrm{cM}$ of distance to EM161461r.

The marker EM2378a is linked at the coupling phase with a resistance allele due to a partial regression coefficient that is negative $(-1.825)$, meaning that its presence is associated with a reduction in DLA. This marker was attributed to the LG 9 on the map of the 'IAPAR-123'. EM2378a was allocated as an accessory marker at $5.7 \mathrm{cM}$ of distance to PM09198a.

A critical value of LOD score 2.36 was established to state the presence of QRL according to the composite interval mapping analysis (CIM) and Churchill and Doerge (1994) procedures using 1,000 permutations and $\alpha=0.05$. Only one QRL was identified and explained $15.8 \%$ of the observed phenotypic variance. This QRL was attributed to LG 2 in the 'IAPAR-123' map at a distance of 0.02 cM to the EM161461r marker (LOD $=4.41$ ) (Figure 2 and 4). According to the regression analysis, this QRL corresponds to the one identified by the PM023558r marker.

The accessory marker PM023558r was identified by the regression analysis as the more appropriate for explaining the variation due to the QRL placed on LG 2 of the 'IAPAR-123' map and, theoretically, it could explain a bigger ratio of variation due to 
this QRL by CIM if included in the map. To verify this possibility, an alternative order of the LG 2 was obtained: the PM023558r marker, previously allocated as accessory, was placed on the map. In this new order, the QRL was identified between the PM023558r and EM01156a markers, coherent position as verified on the LG when this marker was included as accessory. The estimated position of this QRL practically coincides with the position of the PM023558r marker and explains $16.5 \%$ of the total phenotypic variation in the segregating population.

\section{DISCUSSION}

The large number of amplified fragments and the relatively high polymorphism found in the segregating population attest the great potential of the AFLP technique to generate genetic markers in the yellow passion fruit. Carneiro et al. (2002) used 380 RAPD primers for analyzing a passion fruit progeny derived from the same cross, and 113 of these primers (29.7\%) were polymorphic. The authors were able to identify 3,428 bands, an average of 9 fragments per primer. The number of amplified loci generated through the AFLP reactions was six times larger than that generated by the RAPD technique. Some authors e.g. Costa et al. (2000) used RAPDs and AFLPs to construct a genetic map of Pinus pinaster and concluded that the AFLP technique costs were three times lower. Moreover, the time consumed to generate the AFLPs was half that for the generation of the RAPD markers (Lopes et al., 2002). Due to such features, the AFLP procedure is particularly suitable for the construction of linkage maps, including dense maps.

\section{Parental level of heterozygosity}

Heterozygosity levels were compared considering mono-parental polymorphic loci (i.e. 303 loci segregating in a 1:1 ratio): 47.5\% (144/303) of the loci were heterozygous in 'IAPAR-06' and 52.5\% (159/303) in 'IAPAR-123'. These estimates support the results described in Carneiro et al. (2002) who found levels of heterozygosity of $45 \%$ in 'IAPAR-06' and 55\% in 'IAPAR-123' analyzing 269 
monoparental RAPD loci. The high levels of heterozygosity are expected in selfincompatible species (Hemmat et al., 1994; Crouzillat et al., 1996) such as the passion fruit, and perennial or long-cycle species (Kubisiak et al., 1995). The level of heterozygosity is one of the factors that influences the map lengths constructed for individual plants by using the "two way pseudo-testcross" method (Atienza et al., 2002). Despite the great level of heterozygosity found in 'IAPAR-123', its map was smaller than the one of 'IAPAR-06', indicating that this factor was not imperious for determining the length of Passiflora edulis maps.

\section{Distorted segregation of AFLP markers}

If only the levels of individual significance were analyzed $(\alpha=0.05), 20$ loci ( 17\%) of 'IAPAR-06' and 8 (5.5\%) of 'IAPAR-123' would have been considered as deviation from mendelian segregation. However, based on the FDR criteria, 18 loci of 'IAPAR-06' and three of 'IAPAR-123' were included on the maps. These loci would not be included if the criterion to state a distorted segregation was based only on the level of significance for the individual test of $\chi^{2}$. The criteria that control the global significance level are recommended to avoid the type I error, when performing multiple tests (Silva \& Vencovsky, 2002). Carneiro et al. (2002) using the individual significance level of 0.05 , found about $5.0 \%$ of the distorted loci in 'IAPAR-06' and $5.4 \%$ in 'IAPAR-123'. The proportion of distorted RAPD loci in 'IAPAR-06' was much smaller than that found in the present study (i.e. 17\%).

When analyzing the 18 loci that showed significant deviation through the individual $\chi^{2}$ test (0.05) and which were attributed to the 'IAPAR-06' map using the FDR criteria, 10 of those loci (56\%) were allocated on group 1 and 6 (33\%) on group 2. Similar values of $\chi^{2}$ were observed for loci physically near. This shows that the distortion is related to adjacent loci and the deviation rates were not derived from genotyping errors, suggesting that these findings have a biological nature. Distortions in the segregation of AFLP loci have been observed in several species, which magnitude depends on the species and genotypes used for generating a segregating population. 
Reports have shown that these rates range from 4 to 10\% in kiwi (Testolin et al., 2001), have $7 \%$ of magnitude in Populus (Wu et al., 2000) and are greater than $40 \%$ in Cryptomeria japonica (Nikaido et al., 1999; Nikaido et al., 2000). Biological explanations for these distortions are physical proximity between the markers and are due to genes that affect the formation of gametes before the fertilization or genotype feasibility after the fertilization. In addition, the use of small populations and errors in genotype classification are also some of the experimental causes (Liu 1998; Vogl and $\mathrm{Xu}, 2000$ and references there in).

\section{Passiflora linkage maps}

The distribution of markers in nine linkage groups in both parentals indicates that markers have been designated to all chromosomes of the species $(2 n=18)$. However, our results suggest that the distribution of markers in the genome was not randomized. Approximately 64\% of the markers attributed to 'IAPAR-06' map were concentrated in the three largest groups that correspond to $60 \%$ of the map length, while only $10 \%$ of the markers were assembled in the three smallest groups, which correspond to $7 \%$ of the map length. Similarly, $45 \%$ of the markers were designated to the three largest groups of the 'IAPAR-123' map, which correspond to $69 \%$ of the map length, whereas only $20 \%$ of the markers were assembled in the smallest groups or $9.8 \%$ of the map length. Although there are differences in the chromosome sizes of $P$. edulis that vary from 2.6 to $1.7 \mathrm{~mm}$ (Vieira et al., 2004), this fact alone cannot explain the small length of some linkage groups, suggesting that the distribution of the AFLP markers did not occur at random in the groups, which may be extended to the passion fruit chromosomes.

The distribution of RAPD markers was not randomized on the 'IAPAR-06' and 'IAPAR-123' maps (Carneiro et al., 2002). From 96 mono-parental RAPDs of 'IAPAR06', 81\% were assigned to five linkage groups that constituted $76 \%$ of the map length, composed by 9 groups. The co-segregation of two markers (2.1\%) was observed, a proportion similar to that observed for the AFLP markers (1.8\%). Regarding the 'IAPAR-123' map, $57 \%$ of the RAPDs were attributed to three linkage groups that 
together accounted for $43 \%$ of the map length. A co-segregation of 17 RAPD markers (12.6\%) was observed, a value greater than the one found for the AFLP markers (8.7\%).

Although the number of assembled markers in 'IAPAR-123' (138) was almost 20\% greater than in 'IAPAR-06' (112), the proportion of accessory markers allocated on the map of that parental clone was $58.7 \%$. The number of accessory markers was greater than that ordered in six of the nine linkage groups. On the map of 'IAPAR-06', the proportion of accessories was $35.7 \%$, but only in the group 1 this number was larger than ordered markers. The difficulty in obtaining the correct order of the markers, which were placed as accessories on the maps, may be attributed to the existence of clusters in certain chromosome regions, associated to the population mapping size. The map of 'IAPAR-123' was about 62\% of the map length of 'IAPAR-06'. In the RAPD maps constructed by Carneiro et al. (2002) the map length of the parental clones was quite similar i.e. 783.5 cM ('IAPAR-123') and 728 cM ('IAPAR-06'). The latter was smaller, but the difference was not as expressive as in the case of the AFLP maps. It suggests that the existence of AFLP clusters was genotype-dependent. Patterns of chromosome-andcultivar-specific AFLPs clusters were also observed in Petunia, in which the clusters were associated with regions of low recombination frequency (Strommer et al., 2002). In other species like soybean (Young et al., 1999), maize (Castiglioni et al., 1999) and rose (Crespel et al., 2002), the formation of AFLP loci clusters was also observed.

In maize, Young et al. (1999) found the common occurrence of clusters of EcoRI/MseI generated markers by linkage group, but the rare occurrence of markers generated by the PstI enzyme, that is sensitive to the cytosine metylation, in those clusters. Associating these facts to the low frequency of recombination and the high level of cytosine metylation in the heterocromatic blocks around the centromers, the authors suggest that the clusters observed in maize linkage groups should represent centromeric regions. Such relation was not so evident in the linkage groups here obtained. In the Pinus taeda, Remington et al. (1999) developed an AFLP map that covered from 87.5 to $99.6 \%$ of the genome, depending on the method used to calculate its length. Although clusters were observed, their occurrence still enables the construction of AFLP-based maps with a broad coverage of the genome. 


\section{Segregation of resistance to bacteriosis}

The DLA variation in the mapping population, which was verified through the descriptive statistics as well as by the graphic analysis of the means distribution, demonstrated the existence of genetic variation and segregation that allowed the identification of resistance genes from the mapping analysis. The DLA distribution seen by the phenotypic evaluation of the segregating population suggested that the resistance inheritance is oligogenic. Up to now, the studies on the bacteriosis did not evaluate the phenotypic segregation in progenies derived from controlled experiments, which is essential for understanding the genetic nature of the resistance and the definition of passion fruit breeding strategies. Our results are quite informative, but we do believe that other studies are also required in order to yield a broader knowledge of the genetic control of the resistance, and a more effective investigation for the development of resistance varieties should be directed. It is important to emphasize the relevance of studying different bacteria isolates. The analysis of the genetic diversity among Xanthomonas axonopodis pv. passiflorae isolates demonstrated that there is variability for aggressiveness (Gonçalves and Rosato, 2000; Nakatani, 2001) supporting the possibility of existing pathogen-host interactions, which may be important when establishing the breeding strategies.

\section{QRL mapping}

The quantitative resistance locus detected in the present work explained a small part of the phenotypic variation (15.8\%) and, possibly, there are other non-detected QRL with segregating alleles in the mapping population. This may be due to: $i$ ) the existence of a small effect-QRL that cannot be detected within populations of limited sizes (here, 117 individuals); ii) the lesser coverage of the maps, due the separation of the markers into two independent maps, and iii) the necessity of a more accurate phenotypic evaluation. Differences in the capacity for detecting QTL (quantitative trait loci) as well as estimating their effects were reported by Corner et al. (1998) and Grattaplaglia et al. (1995) when using the "twoway pseudo-testcross" strategy. While in genetic designs 
obtained from endogamic lines two QTL alleles segregate, up to four alleles may segregate in a two-way pseudo-testcross derived population. Assuming that for a certain locus, the genotype of one of the parents is $\mathrm{Q}_{1} \mathrm{Q}_{2}$ and for the other one is $\mathrm{Q}_{3} \mathrm{Q}_{4}$ for a single heterozygous and dominant marker, the QTL analysis test the difference between the average score of the characteristic in $\mathrm{Q}_{1} \mathrm{Q}_{3}+\mathrm{Q}_{1} \mathrm{Q}_{4}$ versus $\mathrm{Q}_{2} \mathrm{Q}_{3}+\mathrm{Q}_{2} \mathrm{Q}_{4}$ in one of the parents, or $\mathrm{Q}_{3} \mathrm{Q}_{1}+\mathrm{Q}_{3} \mathrm{Q}_{2}$ versus $\mathrm{Q}_{4} \mathrm{Q}_{1}+\mathrm{Q}_{4} \mathrm{Q}_{2}$ in the case of the other parent. Supposing a quantitative trait locus linked to double heterozygous markers, with a null allele linked to $\mathrm{Q}_{2}$ and $\mathrm{Q}_{4}$, it is possible to verify the difference between the phenotypic means of $\mathrm{Q}_{2} \mathrm{Q}_{4}$ versus $\mathrm{Q}_{1} \mathrm{Q}_{3}+\mathrm{Q}_{1} \mathrm{Q}_{4}+\mathrm{Q}_{2} \mathrm{Q}_{3}$ (Grattapaglia et al., 1995; Conner et al., 1998). In the present study, some specific genetic configurations and/or allelic effects may have limited the QRL mapping capacity as well as the estimation of infra-locus interactions. In spite of all these considerations, at least one QRL was identified, demonstrating that the two-way pseudo-testcross approach and dominant markers may be used for mapping.

In studies of genetic mapping of quantitative resistance using different designs, the individual QRL effects ranged from 5 to $25 \%$ in both perennial and annual species. Boscariol et al. (1998) investigating F8:9 recombinant inbred lines were able to identify eight QRL associated with the plant response to Xanthomonas axonopodis pv. phaseoli, which individually explained from 8 up to $23 \%$ of the overall phenotypic variation in beans. Evaluating F3 families, Ben Chaim et al. (2001) identified six QRL for the CMV virus, which individually explained from 7 to $33 \%$ of the overall phenotypic variation in pepper. Therefore, the QRL here identified have an effect of similar magnitude to the usually found in other pathosystems.

The differences between the DLA means of the genotypes with marker alleles linked to QRL alleles that provide resistance (favorable alleles) and alternative genotypes are listed in Table 3, and expressed as phenotypic standard deviations. Considering the phenotypic means of the genotypes with a marker allele linked to a favorable allele and also the means of the alternative marker genotypes, the differences varied from 0.38 to 0.81 (standard deviations for the mean population $=4.57 \mathrm{~cm}^{2}$ ). However, when considering the phenotypic means of the genotypes with a marker allele linked to a favorable allele, these differences varied from 0.15 to 0.44 . 
Performing a selection of $20 \%$ of the plants of the population (23 plants) showing the genotype markers associated to the DLA reduction i.e. EM01156, EM161461, EM2378 and PM023558, we would have a phenotypic mean of $10.15 \mathrm{~cm}^{2}$, which would be 0.49 phenotypic standard deviations lower than the population mean. Simulating a phenotypic selection of $20 \%$ of the population with the lowest DLA, we would have a phenotypic mean of $7.30 \mathrm{~cm}^{2}$, which would be 1.12 phenotypic standard deviations lower than the phenotypic mean of the population. From the 23 plants selected according to the respective criteria, that is, genotype and phenotype-based criteria, 8 of them were common to both criteria (35\%). The efficiency of the genotypebased selection in relation to the phenotypic selection was only $44.4 \%$ (a reduction of $5.1 \mathrm{~cm}^{2}$ in the DLA by phenotype-based selection versus $2.25 \mathrm{~cm}^{2}$ by marker assisted selection - MAS). We do believe that mapping other QRL, satisfactory efficiency rates of selection will be reached as a greater proportion of the phenotypic variation would be explained.

\section{What is next?}

This report comprises the second investigation on the construction of genetic maps for the Passiflora and the first one that employs AFLP markers. The first maps were constructed using RAPDs (Carneiro et al., 2002) and 90 individuals. During the construction of AFLP maps, 117 individuals of the same segregating population were used. A single map will certainly come up joining the RAPD and AFLP markers. As well, the integration of Passiflora homologous linkage groups will depend on the generation of bridging alleles that segregate in both parents (bi-parental alleles). In future, the idea is to generate microsatellites for Passiflora and use these bridging alleles as co-dominant markers, such as the ones developed for the integration of Hevea spp. maps (Lespinasse et al., 2000) and for the alignment of homologous groups in apple (Maliepaard et al, 1998). We should also make use of dominant bi-parental markers, as reported by Marques et al. (1998) that aligned the maps of Eucalyptus globulus and E. tereticornis. 
As the most important agronomic characteristics are of quantitative inheritance, thus, large populations are necessary to obtain genotypes that concentrate favorable alleles. In addition, passion fruit it is a semi-perennial crop, with a long period of production, requiring large experimental areas and supervised cultivation. Field experiments are difficult to be assessed and relatively expensive. Through, investigations on QTL mapping will certainly increase the efficacy of the breeding programs by reducing the experimental area, time and, consequently, the costs of such programs.

Refinement on the evaluation of resistance should also be considered. Genotype responses depend on artificial inoculation and are difficult to be assessed in large populations. Inoculation with other bacterial isolates is an alternative manner to provide additional information on the effectiveness and specificity of the QRL here found, and other QRL should be detected. Finally, it is important to emphasize that the information provided here has never been studied on this species and, as abovementioned, it will be useful in future research on passion fruit breeding, aimed at the generation of Xanthomonas axonopodis pv. passiflorae-resistant populations. We do consider that marker assisted selection can become a valuable component of a diseased management program in near future.

\section{ACKNOWLEDGEMENTS}

The authors would like to thank to Fundação de Apoio à Pesquisa do Estado de São Paulo for financial support and Ricardo Vieira Cesar for his kind contribution in the proofreading of this manuscript. We also acknowledge Antonio Augusto Franco Garcia for helpful consideration on the biometrical approach. 
Table 1. AFLP loci detected between the passion fruit clones 'IAPAR-06' and 'IAPAR123'. The amplification products were generated using 34 primer combinations of EcoRI/MseI and PstI/MseI enzymes and three arbitrary nucleotides in the selective amplification

\begin{tabular}{|c|c|c|c|c|c|c|c|}
\hline & & & \multicolumn{5}{|c|}{ Polymorphic bands } \\
\hline \multicolumn{3}{|c|}{ Primer combination } & \multicolumn{2}{|c|}{$1: 1$} & \multirow[t]{2}{*}{ Total } & \multirow[t]{2}{*}{$3: 1$} & \multirow[t]{2}{*}{ Total } \\
\hline Code & Prim & nsion & 'IAPAR-06' & 'IAPAR-123 & & & \\
\hline EM01 & $\mathrm{E}+\mathrm{AAA}$ & $\mathrm{M}+\mathrm{CGC}$ & 8 & 5 & 13 & 2 & 15 \\
\hline EM02 & $\mathrm{E}+\mathrm{AAA}$ & $\mathrm{M}+\mathrm{CTA}$ & 5 & 6 & 11 & 5 & 16 \\
\hline EM03 & $\mathrm{E}+\mathrm{AAC}$ & $\mathrm{M}+\mathrm{CAA}$ & 3 & 6 & 9 & 4 & 13 \\
\hline EM04 & $\mathrm{E}+\mathrm{AAC}$ & $\mathrm{M}+\mathrm{CGT}$ & 4 & 5 & 9 & 2 & 11 \\
\hline EM05 & $\mathrm{E}+\mathrm{AAG}$ & $\mathrm{M}+\mathrm{CAA}$ & 3 & 2 & 5 & 4 & 9 \\
\hline EM06 & $\mathrm{E}+\mathrm{AAG}$ & $\mathrm{M}+\mathrm{CAC}$ & 3 & 6 & 9 & 5 & 14 \\
\hline EM07 & $\mathrm{E}+\mathrm{ACC}$ & $\mathrm{M}+\mathrm{CTC}$ & 6 & 3 & 9 & 1 & 10 \\
\hline EM08 & $\mathrm{E}+\mathrm{ACC}$ & $\mathrm{M}+\mathrm{CTG}$ & 5 & 3 & 8 & 3 & 11 \\
\hline EM09 & $\mathrm{E}+\mathrm{ACC}$ & $\mathrm{M}+\mathrm{CTT}$ & 4 & 4 & 8 & 6 & 14 \\
\hline EM10 & $\mathrm{E}+\mathrm{ACG}$ & $\mathrm{M}+\mathrm{CGC}$ & 2 & 4 & 6 & 1 & 7 \\
\hline EM11 & $\mathrm{E}+\mathrm{ACG}$ & $\mathrm{M}+\mathrm{CTT}$ & 3 & 3 & 6 & 1 & 7 \\
\hline EM12 & $\mathrm{E}+\mathrm{ACT}$ & $\mathrm{M}+\mathrm{CGC}$ & 1 & 4 & 5 & 2 & 7 \\
\hline EM13 & $E+A G G$ & $\mathrm{M}+\mathrm{CAA}$ & 7 & 6 & 13 & 5 & 18 \\
\hline EM14 & $\mathrm{E}+\mathrm{AGG}$ & $\mathrm{M}+\mathrm{CAG}$ & 3 & 4 & 7 & 4 & 11 \\
\hline EM15 & $\mathrm{E}+\mathrm{AGG}$ & $\mathrm{M}+\mathrm{CTT}$ & 5 & 8 & 13 & 3 & 16 \\
\hline EM16 & $\mathrm{E}+\mathrm{ACA}$ & $\mathrm{M}+\mathrm{CAA}$ & 8 & 8 & 16 & 8 & 24 \\
\hline EM17 & $\mathrm{E}+\mathrm{ACA}$ & $\mathrm{M}+\mathrm{CAC}$ & 3 & 6 & 9 & 5 & 14 \\
\hline EM18 & $\mathrm{E}+\mathrm{ACA}$ & $\mathrm{M}+\mathrm{CTC}$ & 7 & 3 & 10 & 6 & 16 \\
\hline EM19 & $\mathrm{E}+\mathrm{AGA}$ & $\mathrm{M}+\mathrm{CAG}$ & 5 & 5 & 10 & 3 & 13 \\
\hline EM20 & $\mathrm{E}+\mathrm{TAC}$ & M+GGT & 5 & 4 & 9 & 5 & 14 \\
\hline EM21 & $\mathrm{E}+\mathrm{TAG}$ & $\mathrm{M}+\mathrm{GCT}$ & 6 & 7 & 13 & 7 & 20 \\
\hline EM22 & $\mathrm{E}+\mathrm{TAT}$ & $\mathrm{M}+\mathrm{GGC}$ & 8 & 7 & 15 & 2 & 17 \\
\hline EM23 & $\mathrm{E}+\mathrm{TTA}$ & $\mathrm{M}+\mathrm{GGT}$ & 3 & 4 & 7 & 3 & 10 \\
\hline EM24 & $\mathrm{E}+\mathrm{AGA}$ & $\mathrm{M}+\mathrm{CAA}$ & 8 & 9 & 17 & 3 & 20 \\
\hline Total EM & & & 115 & 122 & 237 & 90 & 327 \\
\hline Average EM & & & 4.79 & 5.08 & 9.88 & 3.75 & 13.63 \\
\hline PM01 & $\mathrm{P}+\mathrm{ACA}$ & $\mathrm{M}+\mathrm{CAC}$ & 3 & 3 & 6 & 2 & 8 \\
\hline PM02 & $\mathrm{P}+\mathrm{ACA}$ & $\mathrm{M}+\mathrm{CAG}$ & 5 & 4 & 9 & 6 & 15 \\
\hline PM03 & $\mathrm{P}+\mathrm{ACC}$ & $\mathrm{M}+\mathrm{CAC}$ & 1 & 4 & 5 & 6 & 11 \\
\hline PM04 & $\mathrm{P}+\mathrm{ACT}$ & $\mathrm{M}+\mathrm{CAG}$ & 5 & 4 & 9 & 6 & 15 \\
\hline PM05 & $\mathrm{P}+\mathrm{AGC}$ & $\mathrm{M}+\mathrm{CGT}$ & 1 & 1 & 2 & 1 & 3 \\
\hline PM06 & $\mathrm{P}+\mathrm{AAC}$ & $\mathrm{M}+\mathrm{CTA}$ & 3 & 7 & 10 & 2 & 12 \\
\hline PM07 & $\mathrm{P}+\mathrm{ACG}$ & $\mathrm{M}+\mathrm{CTG}$ & 1 & 3 & 4 & 2 & 6 \\
\hline PM08 & $\mathrm{P}+\mathrm{AGC}$ & $\mathrm{M}+\mathrm{CTA}$ & 3 & 4 & 7 & 0 & 7 \\
\hline PM09 & $\mathrm{P}+\mathrm{AGA}$ & $\mathrm{M}+\mathrm{CAC}$ & 5 & 2 & 7 & 1 & 8 \\
\hline PM10 & $\mathrm{P}+\mathrm{AAA}$ & $\mathrm{M}+\mathrm{CAC}$ & 3 & 5 & 8 & 0 & 8 \\
\hline Total PM & & & 29 & 37 & 66 & 26 & 92 \\
\hline Average PM & & & 2.9 & 3.7 & 6.6 & 2.6 & 9.2 \\
\hline Total & & & 144 & 159 & 303 & 116 & 419 \\
\hline Average & & & 4.24 & 4.68 & 8.91 & 3.41 & 12.32 \\
\hline
\end{tabular}


Table 2. Description of the linkage maps of the passion fruit clones 'IAPAR-06' and 'IAPAR-123'constructed from 303 AFLP markers using the two-way pseudotestcross mapping strategy. Haldane’s mapping function was used to convert recombination frequencies to map distances in centimorgans (cM)

\begin{tabular}{lcc}
\hline & 'IAPAR-06' & 159 \\
\hline Number of loci & 144 & 6 \\
Number of distorted markers & 2 & 13 \\
Markers shown in less than 100 genotypes & 27 & 140 \\
Markers used for the maps construction & 115 & 9 \\
Number of linkage groups & 9 & 2 \\
Number of unlinked markers & 3 & 57 \\
Markers commanded in framework & 72 & 81 \\
Accessory markers & 39 & 488.9 \\
Map length (cM) & 790.2 & 140.4 \\
Length of the larger group & 208.2 & 8.1 \\
Length of the smaller group & 11.9 & $54.3(47.9)$ \\
Average length of the groups (sd) & $87.8(66.3)$ & $9.6(9.3)$ \\
Marker density (sd) & $12.6(10,8)$ & \\
\hline Sd $=$ standard deviations & &
\end{tabular}

Table 3. Differences between phenotypic DLA (diseased leaf area) means of genotype marker-allele linked to a favorable QRL-allele associated to the plant response against Xanthomonas axonopodis pv. passiflorae inoculation and alternative genotypes

\begin{tabular}{|c|c|c|c|c|c|}
\hline \multirow[t]{2}{*}{ Marker } & \multirow[t]{2}{*}{$\begin{array}{c}\text { Linkage phase of allele } \\
\text { marker }^{1} \text { with favorable QRL } \\
\text { allele }\end{array}$} & \multicolumn{2}{|c|}{$\begin{array}{c}\text { Genotype means } \\
\text { (standard deviations) } \\
\left(\mathrm{cm}^{2}\right)\end{array}$} & \multirow[t]{2}{*}{$\begin{array}{c}\Delta^{2} \\
\left(\mathrm{~cm}^{2}\right)\end{array}$} & \multirow[t]{2}{*}{$\begin{array}{c}\Delta^{3} \\
\left(\mathrm{~cm}^{2}\right)\end{array}$} \\
\hline & & $1-$ & 00 & & \\
\hline EM01156 & Coupling & $11.28(4.08)$ & $13.69(4.88)$ & -0.53 & -0.23 \\
\hline EM161461 & Repulsion & $14.06(4.96)$ & 10.41 (3.19) & -0.80 & -0.44 \\
\hline EM2378 & Coupling & 11.53 (4.11) & $13.28(4.91)$ & -0.38 & -0.15 \\
\hline PM023558 & Repulsion & 14.34 (5.07) & $10.62(3.19)$ & -0.81 & -0.39 \\
\hline
\end{tabular}

*amplified allele; $†$ difference between the favorable allele-genotype means and alternative genotype means expressed as phenotypic standard deviations; łdifference between the favorable allele-genotype means and the population mean expressed as phenotypic standard deviations 


\section{GROUP 1}

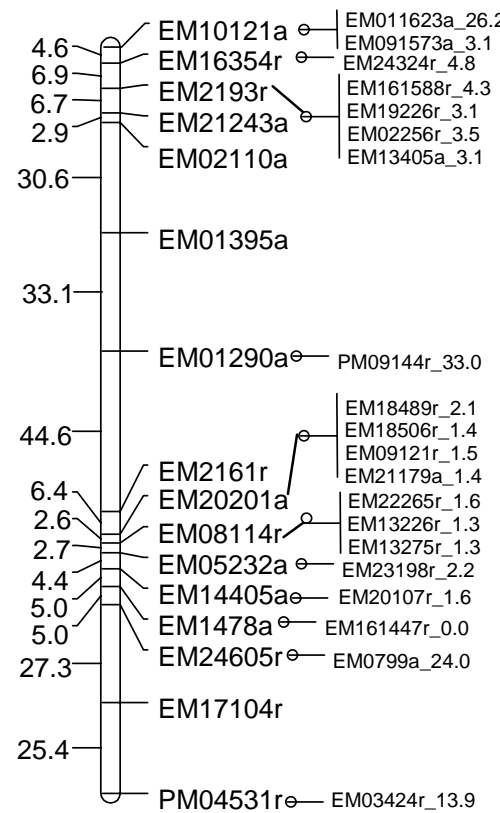

\section{GROUP 4}

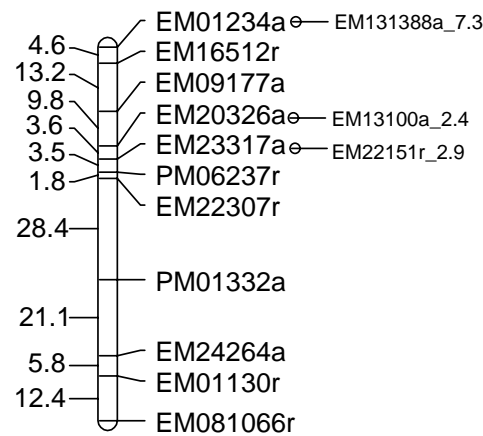

GROUP 7

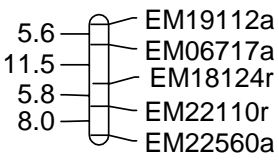

\section{GROUP 2}

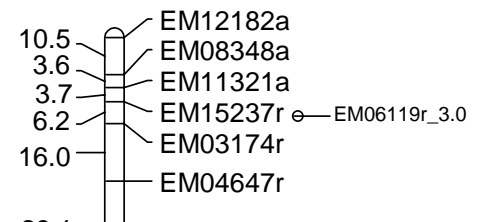

\section{GROUP 3}

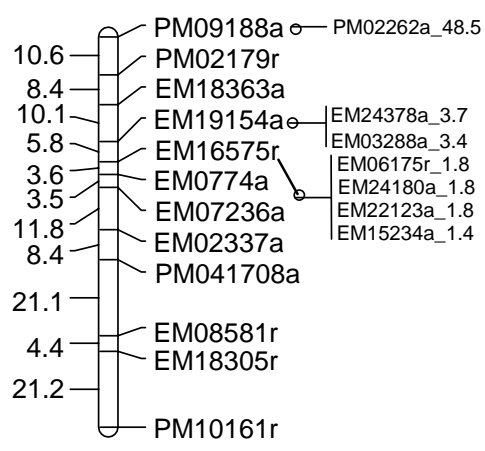

\section{GROUP 5}

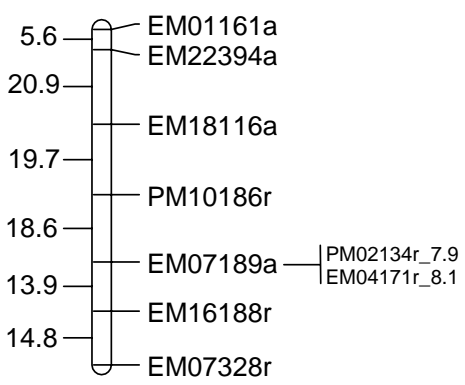

\section{GROUP 8}

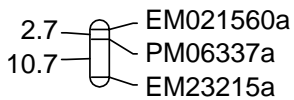

\section{GROUP 6}

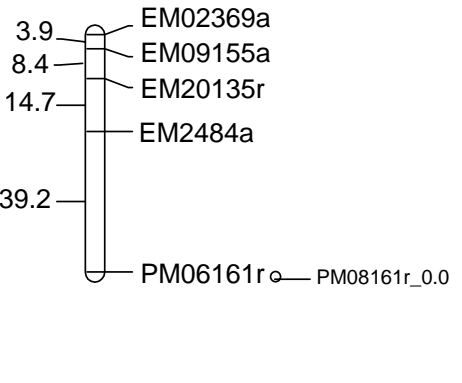

\section{GROUP 9}

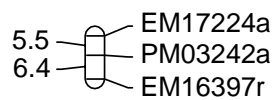

Figure 1. Genetic linkage map of Passiflora edulis flavicarpa 'IAPAR-06'. Linkage relationships of 112 AFLP markers in 9 linkage groups were established at a threshold LOD score of 3.0 and maximum $\Theta=0.50$. AFLP marker loci accessories are listed on the right of the linkage groups along with the closest framework locus. 


\section{GROUP 1}

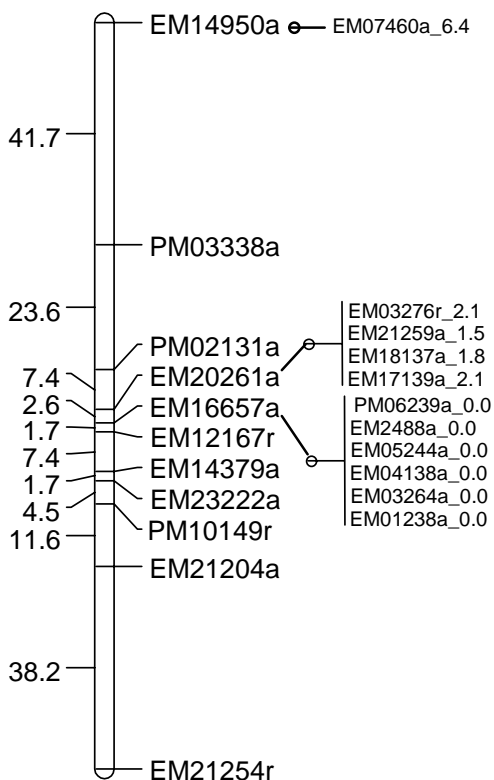

\section{GROUP 4}
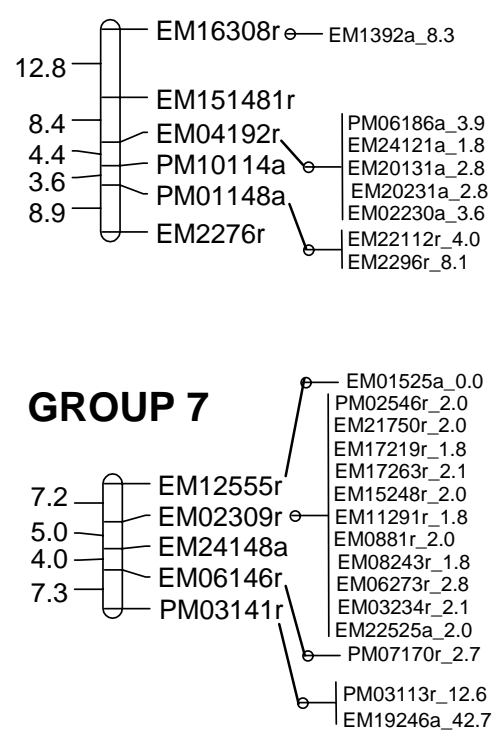

GROUP 2

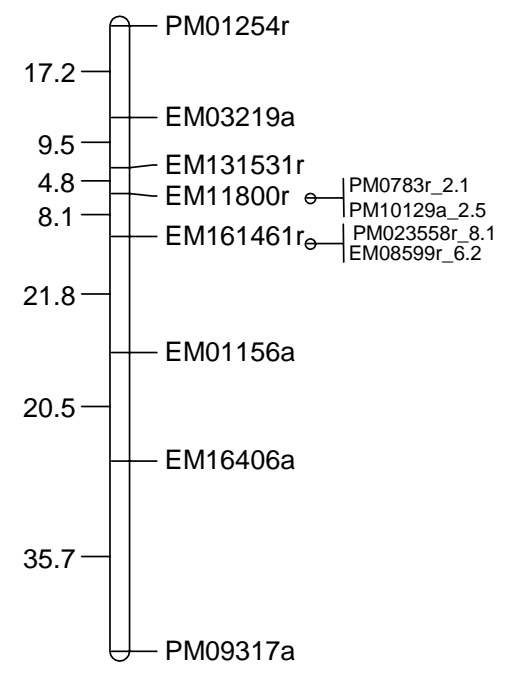

\section{GROUP 5}

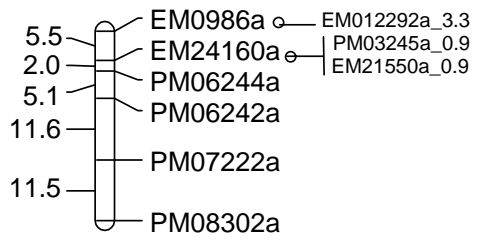

\section{GROUP 3}

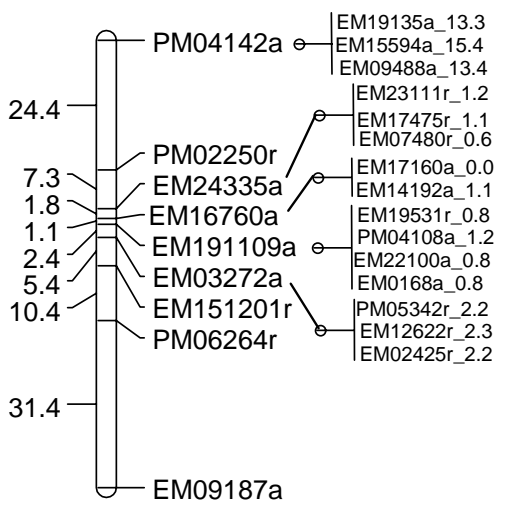

\section{GROUP 6}
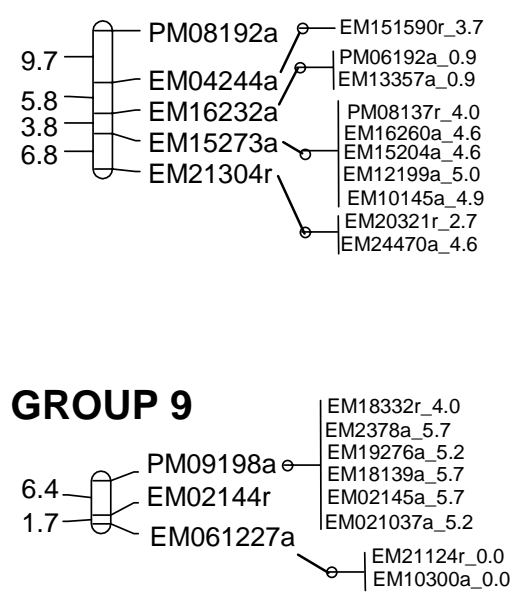

Figure 2. Genetic linkage mapa of Passiflora edulis flavicarpa 'IAPAR-123'. Linkage relationships of 138 AFLP markers in 9 linkage groups were established at a threshold LOD score of 4.0 and maximum $\Theta=0.30$. AFLP marker loci accessories are listed on the right of the linkage groups along with the closest framework locus. 


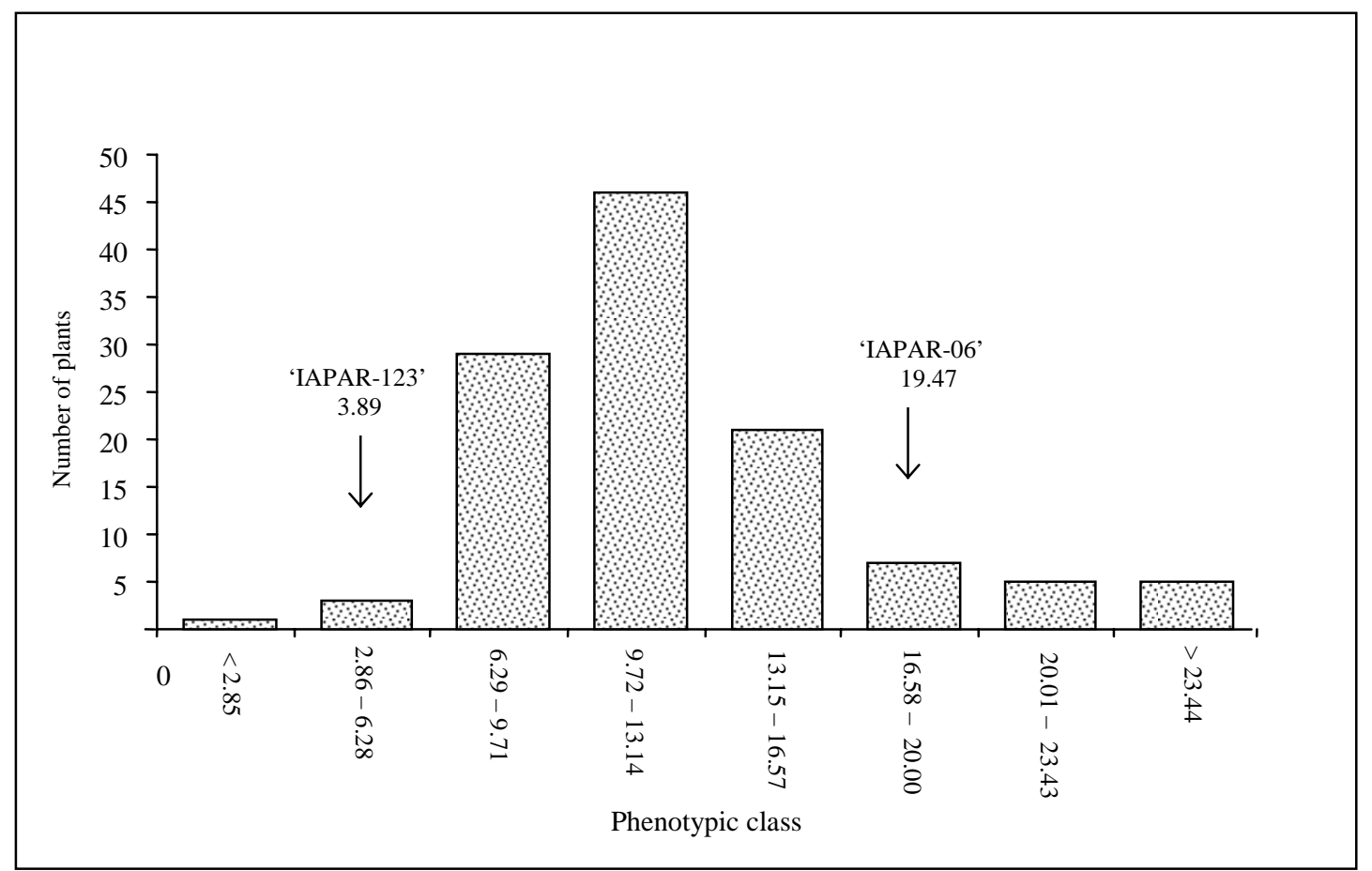

Figure 3. Frequency distribution of mean diseased leaf area $(\mathrm{cm} 2)$ in the yellow passion fruit segregating population composed of 117 individuals (F1) that were inoculated with Xanthomonas axonopodis pv. passiflorae.

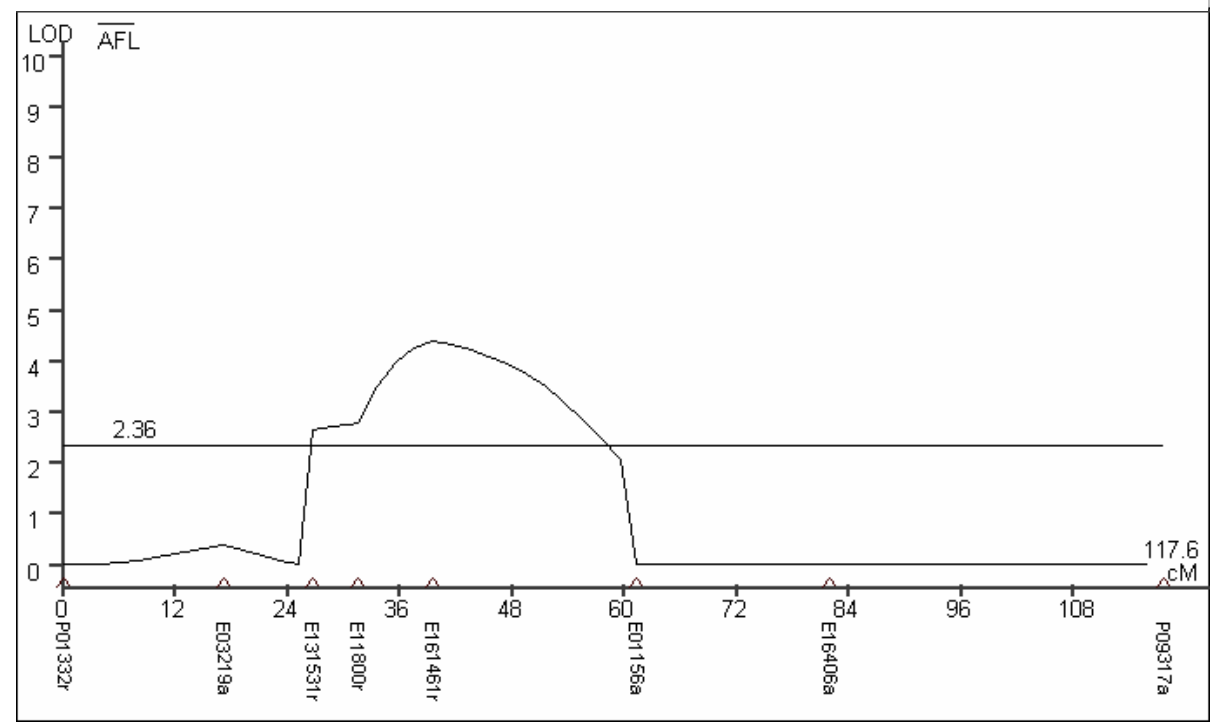

Figure 4. LOD score plots showing location of one QRL mapped on linkage group 2 of 'IAPAR-123' parental clone. Marker names and map distances (cM) are shown on the horizontal axis. 


\section{REFERENCES}

ATIENZA, S.G., SATOVIC, Z., PETERSEN, K.K., DOLSTRA, O, and MARTÍN, A. 2002. Preliminary genetic linkage map of Miscanthus sinensis with RAPD markers. Theoretical and Applied Genetics 105: 946-952.

BEN CHAIM, A., GRUBE, R.C., LAPIDOT, M., and JAHN, M. 2001. Identification of quantitative trait loci associated with resistance to cucumber mosaic virus in Capsicum annuum. Theoretical and Applied Genetics 102: 1213-1220.

BOSCARIOL, R., SOUZA, A.A., TSAI, S.M., and CAMARGO, L.E.A. 1998. Mapeamento de regiões genômicas associadas à resistência a dois isolados de Xanthomonas axonopodis pv. phaseoli em feijoeiro. Fitopatologia Brasileira 23: 135-138.

CANÇADO JR., F.L., ESTANISLAU, M.L.L., and PAIVA, B.M. 2000. Aspectos econômicos da cultura do maracujá. Informe Agropecuário 21: 10 - 17.

CARNEIRO, M.S., CAMARGO, L.E.A., COELHO, A.S.G., VENCOVSKY, R., LEITE JÚNIOR, R.P., STENZEL, N.M.C., and VIEIRA, M.L.C. 2002. RAPD-based genetic linkage maps of yellow passion fruit (Passiflora edulis Sims. f. flavicarpa Deg.). Genome 45: 670-678.

CASTIGLIONI, P., AJMONE-MARSAN, P., VAN WIJK, R., and MOTTO, M. 1999. AFLP markers in a molecular linkage map of maize: codominant scoring and linkage group distribuition. Theoretical and Applied Genetics 99: 425-431.

CHURCHILL, G.A., and DOERGE, R.W. 1994. Empirical threshold values for quantitative trait mapping. Genetics 138: 963-971.

CONNER, P.J., BROWN, S.K., and WEEDEN, N.F. 1998. Molecular marker analysis of quantitative traits for growth and development in juvenile apple trees. Theoretical and Applied Genetics 96: 1027- 1035.

COSTA, P., POT, D., DUBOS, C., FRIGERIO, J.M., PIONNEAU, C., BODENES, C., BERTOCHI, E., CERVERA, M.T., REMINGTON, D.L., and PLOMION, C. 2000. A genetic map of maritime pine based on AFLP, RAPD and protein markers. Theoretical and Applied Genetics 100: 39-48.

CRESPEL, L., CHIROLleT, M., DUREL, C.E., ZHANG, D., MEYNET, J., and GUDIN, S. 2002. Mapping of qualitative and quantitative phenotypic traits in Rosa using AFLP markers. Theoretical and Applied Genetics 105: 1207-1214.

CRESTE, S., TULMANN NETO, A., and FIGUEIRA, A. 2001. Detection of single sequence repeat polymorfisms in denaturing polyacrylamide sequencing gels by silver staining. Plant Molecular Biology Reporter 19: 299-306.

CROUZILLAT, D., LERCETEAU, E., PETIARD, V., MORERA, J., RODRIGUEZ, H., WALKER, D., PHILLIPS, W., RONNING, C., SCHNELL, R., OSEI, J., and FRITZ, P. 1996. Theobroma cacao L.: a genetic linkage map and quantitative trait loci analysis. Theoretical and Applied Genetics 93: 205- 214.

DRAPER, J.M., and SMITH, H. 1981. Applied regression analysis. 2.ed. John Wiley \& Sons, New York. 709p.

EDWARDS, M.D., STUBER, C.W., and WENDELL, J.F. 1987. Molecular marker facilitated investigations of quantitative trait loci in maize. I. Numbers, genomic distribution, and types of gene action. Genetics: 116: 113-125. 
GRATTAPAGLIA, D., and SEDEROFF, R. 1994. Genetic linkage maps of Eucalyptus grandis e Eucalyptus urophylla using a pseudo-testcross: mapping strategy and RAPD markers. Genetics 137: 1121-37.

GRATTAPAGLIA, D., BERTOLUCCI, F.L., and SEDEROFF, R.R. 1995. Genetic mapping of quantitative trait loci controlling vegetative propagation in Eucalyptus grandis and E. urophylla using a pseudo-testcross mapping strategy and RAPD markers. Theoretical and Applied Genetics 90: 933- 947.

GONÇALVES, E.R., and ROSATO, Y.B. Genotypic characterization of xanthomonad strains isolated from passion fruit plants (Passiflora spp.) and their relatedness to different Xanthomonas species. 2000. International Journal of Systematic and Evolutionary Microbiology 50: 811-821.

HEMMAT, M., WEEDEN, N.F., MANGANARIS, A.G., and LAWSON, D.M. 1994. Molecular marker linkage map for apple. Journal of Heredity 85: 4-11.

KUBISIAK, T.C., NELSON, C.D., NANCE, W.L., and STINE, M. 1995. RAPD linkage mapping in a longleaf pine x slash pine F1 family. Theoretical and Applied Genetics 90: 1119-1127.

LANDER, E.S., GREEN, P., ABRAHAMSON, J., BARLOW, A., DALY, M.J., LINCOLN, E.E., and NEWBURG, L. 1987. Mapmaker: an interactive computer package for constructing primary genetic linkage maps of experimental and natural populations. Genomics 1: 174-81.

LESPINASSE, D., RODIER, G.M., GRIVET, L., LECONTE, A., LEGNATE, H., and SEGUIN, M. A saturated genetic map linkage of rubber tree (Hevea spp.) based on RFLP, AFLP, microsatellite and isozymes markers. 2000. Theoretical and Applied Genetics 100: 127-138.

LILLIEFORS, H. 1967. On the Kolmogorov-Smirnov test for normality with mean and variance unknown. Journal of the American Statistical Association 62: 399-402.

LIU, B.H. Statistical genomics. 1998. CRC Press, New York, 610p.

LOPES, R., LOPES, M.T.G., FIGUEIRA, A.V.O., CAMARGO, L.E.A., FUNGARO, M.H.P., CARNEIRO, M.S., AND VIEIRA, M.L.C. 2002. Marcadores moleculares dominantes (Rapd e Aflp): Aspectos técnicos e interpretação genética. BIOtecnologia Ciência \& Desenvolvimento 29: 56- 60.

MALIEPAARD, C., ALSTON, F.H., VAN ARKEL, G., BROWN, L.M., CHEVREAU, E., DUNEMANN, F., EVANS, K.M., GARDINER, S., GUILFORD, P., VAN HEUSDEN, A.W., JANSE, J., LAURENS, F., LYNN, J.R., MANGANARIS, A.G., DEN NIJS, A.P.M., PERIAM, N., RIKKERINK, E., ROCHE, P., RYDER, C., SANSAVINI, S., SCHMIDT, H., TARTARINI, S., VERHAEGH, J.J., VRIELINGVAN GINKEL, M., and KING, G.J. 1998. Aligning male and female linkage maps of apple (Malus pumila Mill.) using multi-allelic markers. Theoretical and Applied Genetics 97: 60-73.

MARQUES, C.M., ARAÚJO, J.A., FERREIRA, J.G., WHETTEN, R., O’MALLEY, D.M., and SEDEROFF, R. 1998. AFLP genetics maps of Eucalyptus globulus and E. tereticornis. Theoretical and Applied Genetics 96: 727-737.

MELETTI, L.M.M., and BRUCKNER, C.H. Melhoramento genético. 2001. In Maracujá: tecnologia de produção, pós-colheita, agroindústria, mercado. Edited by C.H. Bruckner and M.C. Picanço. Cinco Continentes, Porto Alegre, pp. 345-385. 
NAKATANI, A.K. 2001. Diversidade genética de Xanthomonas campestris pv. passiflorae e sensibilidade a produtos químicos. Universidade de São Paulo, Piracicaba, 61p. (Master thesis).

NIKAIDO, A., YOSHIMARU, H., TSUMURA, Y., SUYAMA, Y., MURAI, M., and NAGASAKA, K. Segregation distortion for AFLP markers in Cryptomeria japonica. 1999. Genes and Genetic Systems 74: 55-59.

NIKAIDO, A., UJINO, T., IWATA, H., YOSHIMURA, K., YOSHIMURA, H., SUYAMA, Y., MURAI, M., NAGASAKA, K., and TSUMURA, Y. 2000. AFLP and CAPS linkage maps of Cryptomeria japonica. Theoretical and Applied Genetics 100: 825-831.

PIO-RIBEIRO, G., and MARIANO, R.L.R. 1997. Doenças do maracujazeiro (Passiflora spp.) In Manual de fitopatologia: Doenças das plantas cultivadas. Edited by $\mathrm{H}$. Kimati, L. Amorim, A. Bergamin-Filho, L.E.A. Camargo, and J.A.M. Rezende. 3th ed. Agronômica Ceres, São Paulo, Vol. 2, pp.525- 537.

REMINGTON, D.L., WHETTEN, R.W., LIU, B.H., and O’MALLEY, D.M. 1999. Construction of an AFLP genetic map with nearly complete genome coverage in Pinus taeda. Theoretical and Applied Genetics 98: 1279-1292.

SCOTT, D.W. On optimal and data-based histograms. 1979. Biometrika 66: 605-610.

SILVA, H.D., and VENCOVSKY, R. 2002. Testes múltiplos e associação de marcas associadas a QTL's. Scientia Agricola 99: 755-762.

STROMMER, J., PETERS, J., ZETHOF, J., KEUKELEIRE, P., and GERATS, T. 2002. AFLP maps of Petunia hybrida: building maps when markers cluster. Theoretical and Applied Genetics 105: 1000- 1009.

TESTOLIN, R., HUANG, W.G., CIPRIANI, G., and RETAMALES, J. 2001. Towards a linkage map in kiwifruit (Actinidia chinensis Planch.) based on microsatellites and satured with AFLP markers. Acta Horticulturae 498: 79-84.

VIEIRA, M.L.C., BARBOSA, L.V., and MAYEDA, L.Y. Citogenética dos maracujazeiros (Passiflora spp). In Produção e qualidade na Passicultura. Edited by A.A. Lima and M.A.P. Cunha. Embrapa, Cruz das Almas, pp. 45-65.

VIEIRA, M.L.C., FUNGARO, M.H.P., JUBIER, M.F., and LEJEUNE, B. 1997. Determination of taxonomic relationships among Brazilian taxa of Stylosanthes Sw. Leguminosae, using RAPD markers. Pesquisa Agropecuária Brasileira 32: 305-310.

VOGL, C., and XU, S. Multipoint mapping of viability and segregation distorting loci using molecular markers. 2000. Genetics 155: 1439-1447.

VOS, P., HOGERS, R., BLEEKER, M., REIJANS, M., VAN DE LEE, T., HORNES, M., FRIJTERS, A., POT, J., PELEMAN, J., KUIPER, M., and ZABEAU, M. 1995. AFLP: a new technique for DNA fingerprinting. Nucleic Acids Research 23: 44074414.

WILLIAMS, J.G.K., KUBELIK, A.R., LIVAK, K.J., RAFALSKI, J.A., and TINGEY, S.V. 1990. DNA polymorphisms amplified by arbitrary primers are useful as genetic markers. Nucleic Acids Research 18: 6531-6535.

WU, R.L., HAN, Y.F., HU, J.J., FANG, J.J., LI, L., LI, M.L., and ZENG, Z.B. 2000. An integrated genetic map of Populus deltoides based on amplified fragment length polymorphisms. Theoretical and Applied Genetics 100: 1249-1256. 
YOUNG, W.P., SCHUPP, J.M., KEIM., P. 1999. DNA methylation and AFLP marker distribution in the soybean genome. 1999. Theoretical and Applied Genetics 99:785792.

ZENG, Z.B. Precision mapping of quantitative trait loci. 1994. Genetics 136: 14571468. 
APÊNDICE 2

- Dados para as análises (CD-ROM). 